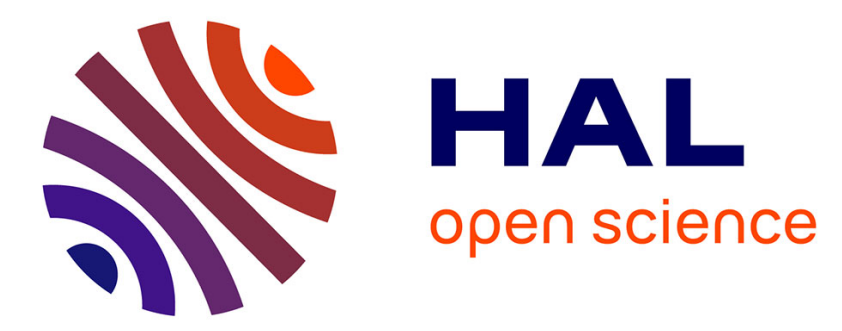

\title{
Cost and Revenue Overruns of the Olympic Games 2000-2018
}

\author{
Wladimir Andreff, Maike Weitzmann, Holger Preuss
}

\section{To cite this version:}

Wladimir Andreff, Maike Weitzmann, Holger Preuss. Cost and Revenue Overruns of the Olympic Games 2000-2018. Gabler Verlag. Springer, 2019, Event- und Impaktforschung, Holger Preuß; Markus Kurscheidt, 978-3-658-24995-3. 10.1007/978-3-658-24996-0 . hal-03231936

\section{HAL Id: hal-03231936 https://hal.science/hal-03231936}

Submitted on 21 May 2021

HAL is a multi-disciplinary open access archive for the deposit and dissemination of scientific research documents, whether they are published or not. The documents may come from teaching and research institutions in France or abroad, or from public or private research centers.
L'archive ouverte pluridisciplinaire HAL, est destinée au dépôt et à la diffusion de documents scientifiques de niveau recherche, publiés ou non, émanant des établissements d'enseignement et de recherche français ou étrangers, des laboratoires publics ou privés. 
Event- und Impaktforschung

Holger Preuß · Markus Kurscheidt Hrsg.

Holger Preuß - Wladimir Andreff

Maike Weitzmann

Cost and Revenue

Overruns of the

Olympic Games

2000-2018

OPEN

Springer Gabler 


\section{Event- und Impaktforschung}

\section{Reihe herausgegeben von}

H. Preuß, Mainz, Deutschland

M. Kurscheidt, Bayreuth, Deutschland 
Die Reihe bietet ein Forum für empirische Studien zur ökonomischen Wirkungsanalyse von Großveranstaltungen in Sport, Kultur und Tourismus. Die Bände beleuchten gleichermaßen die Effekte der Großereignisse auf ihr sozioökonomisches Umfeld als auch den Einfluss von Standortfaktoren auf die Wettbewerbsfähigkeit und Governance der Eventwirtschaft. Die Themenfelder umfassen alle Stakeholder von Events und reichen von Primärerhebungen zum Reise- und Konsumverhalten von Eventbesuchern sowie zu Werbe- und Imagewirkungen von Großveranstaltungen über den gesellschaftlichen Beitrag von Events, etwa zum Volunteering, bis zu Analysen der Eventinfrastruktur wie Stadien- und Ligenmärkte oder Finanzierungsquellen. Die Schriftenreihe richtet sich an Lehrende und Studierende der Wirtschafts-, Sport- oder Tourismuswissenschaft sowie an Praktiker und öffentliche Entscheidungsträger in eventbezogenen Handlungsfeldern.

\section{Reihe herausgegeben von}

Prof. Dr. Holger Preuß

Universität Mainz, Deutschland

Prof. Dr. Markus Kurscheidt

Universität Bayreuth, Deutschland

Weitere Bände in der Reihe http://www.springer.com/series/12513 
Holger Preuß - Wladimir Andreff Maike Weitzmann

\section{Cost and Revenue \\ Overruns of the Olympic Games 2000-2018}


Holger Preuß

Johannes Gutenberg-University Mainz

Mainz, Germany

Maike Weitzmann

Johannes Gutenberg-University Mainz

Mainz, Germany
Wladimir Andreff

Ledignan, France

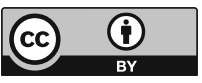

Event- und Impaktforschung

ISBN 978-3-658-24995-3 ISBN 978-3-658-24996-0 (eBook)

https://doi.org/10.1007/978-3-658-24996-0

Library of Congress Control Number: 2018965931

Springer Gabler

(C) The Editor(s) (if applicable) and The Author(s) 2019. This book is an open access publication.

Open Access This book is licensed under the terms of the Creative Commons Attribution 4.0 International License (http://creativecommons.org/licenses/by/4.0/), which permits use, sharing, adaptation, distribution and reproduction in any medium or format, as long as you give appropriate credit to the original author(s) and the source, provide a link to the Creative Commons licence and indicate if changes were made.

The images or other third party material in this book are included in the book's Creative Commons licence, unless indicated otherwise in a credit line to the material. If material is not included in the book's Creative Commons licence and your intended use is not permitted by statutory regulation or exceeds the permitted use, you will need to obtain permission directly from the copyright holder.

The use of general descriptive names, registered names, trademarks, service marks, etc. in this publication does not imply, even in the absence of a specific statement, that such names are exempt from the relevant protective laws and regulations and therefore free for general use.

The publisher, the authors, and the editors are safe to assume that the advice and information in this book are believed to be true and accurate at the date of publication. Neither the publisher nor the authors or the editors give a warranty, express or implied, with respect to the material contained herein or for any errors or omissions that may have been made. The publisher remains neutral with regard to jurisdictional claims in published maps and institutional affiliations.

This Springer Gabler imprint is published by the registered company Springer Fachmedien Wiesbaden GmbH part of Springer Nature

The registered company address is: Abraham-Lincoln-Str. 46, 65189 Wiesbaden, Germany 


\section{Contents}

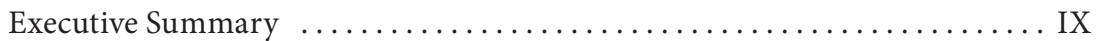

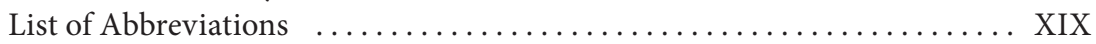

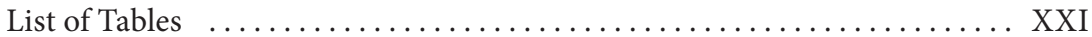

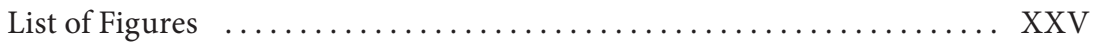

1 Introduction $\ldots \ldots \ldots \ldots \ldots \ldots \ldots \ldots \ldots \ldots \ldots \ldots \ldots \ldots \ldots \ldots \ldots \ldots \ldots \ldots$

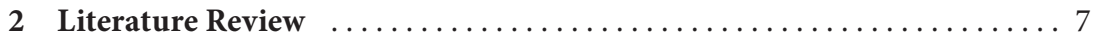

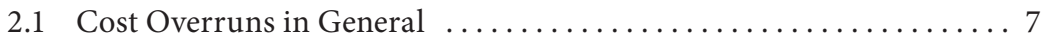

2.1.1 What are Cost Overruns? .................... 7

2.2.2 Cost Overruns in Mega Projects and at Olympic Games ..... 8

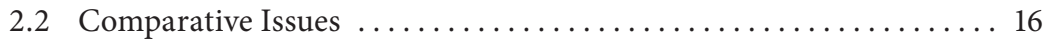

2.3 Olympic Games and Mega Sports Events $\ldots \ldots \ldots \ldots \ldots \ldots \ldots$

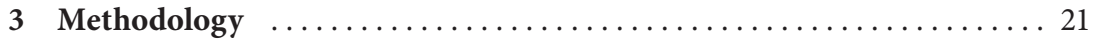

3.1 Availability of Financial Data from the Olympic Games ........ 23

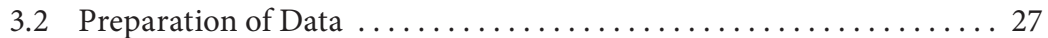

3.3 Quality of Data and Building of Categories .............. 34

3.4 Problems in the Preparation of Data ................... 35

3.5 Building of OCOG and Non-OCOG Budget Categories ......... 37

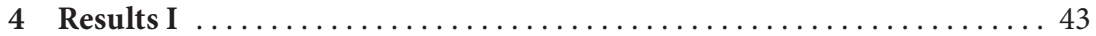

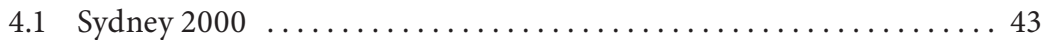

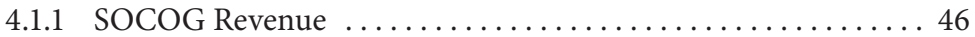

4.1 .2 SOCOG Expenditure $\ldots \ldots \ldots \ldots \ldots \ldots \ldots \ldots \ldots \ldots \ldots$

4.1.3 Sydney 2000 Non-OCOG Costs $\ldots \ldots \ldots \ldots \ldots \ldots \ldots \ldots \ldots$ 


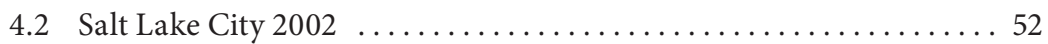

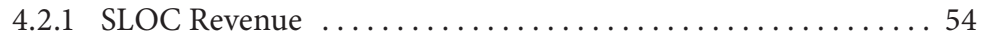

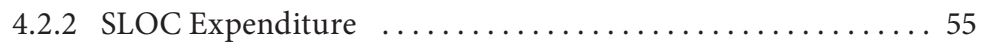

4.2.3 Salt Lake City 2002 Non-OCOG Costs . . . . . . . . . . . . 57

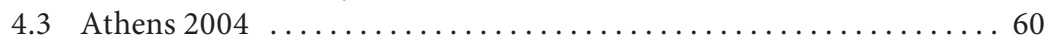

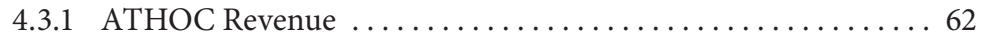

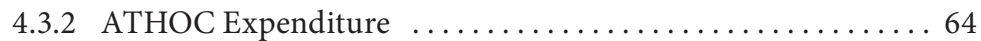

4.3.3 Athens 2004 Non-OCOG Costs ................... 66

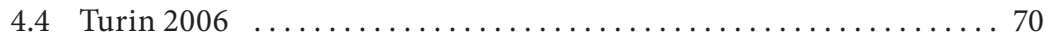

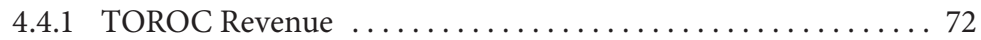

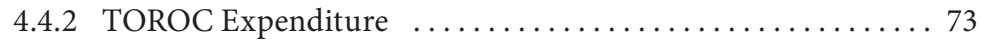

4.4.3 Turin 2006 Non-OCOG Costs . . . . . . . . . . . . . . . . 75

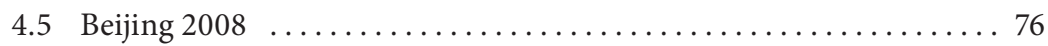

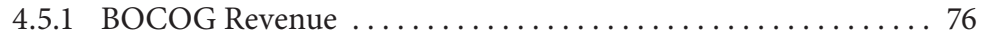

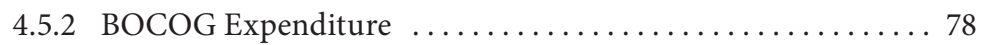

4.5.3 Beijing 2008 Non-OCOG Costs ................ 80

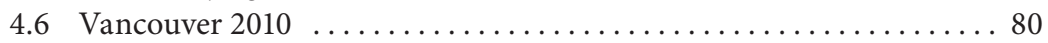

4.6 .1 VANOC Revenue $\ldots \ldots \ldots \ldots \ldots \ldots \ldots \ldots \ldots \ldots \ldots \ldots \ldots$

4.6.2 VANOC Expenditure $\ldots \ldots \ldots \ldots \ldots \ldots \ldots \ldots \ldots \ldots \ldots . \ldots \ldots$

4.6.3 Vancouver 2010 Non-OCOG Costs ................. 84

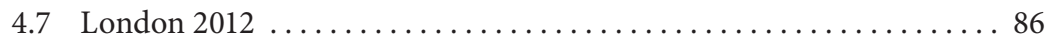

4.7 .1 LOCOG Revenue $\ldots \ldots \ldots \ldots \ldots \ldots \ldots \ldots \ldots \ldots \ldots . \ldots \ldots \ldots$

4.7.2 LOCOG Expenditure $\ldots \ldots \ldots \ldots \ldots \ldots \ldots \ldots \ldots \ldots \ldots \ldots$

4.7.3 London 2012 Non-OCOG Costs . . . . . . . . . . . . . . 93

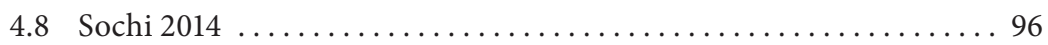

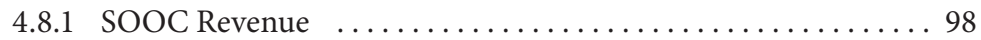

4.8.2 SOOC Expenditure .......................... 99

4.8.3 Sochi 2014 Non-OCOG Costs ... . . . . . . . . . . . . . . . 101

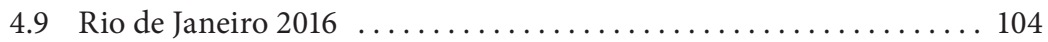

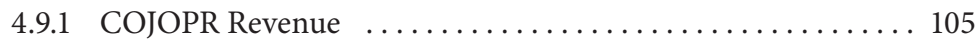

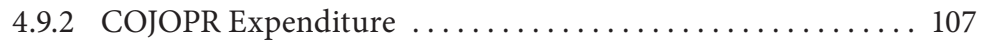

4.9.3 Rio 2016 Non-OCOG Costs . . . . . . . . . . . . . . . . . . . 108

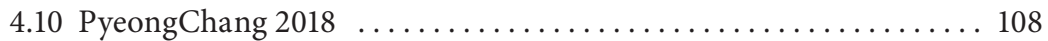

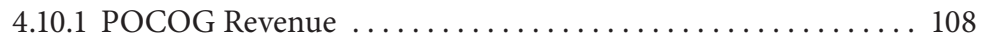

4.10 .2 POCOG Expenditure $\ldots \ldots \ldots \ldots \ldots \ldots \ldots \ldots \ldots \ldots \ldots$

4.10.3 PyeongChang 2018 Non-OCOG Costs . . . . . . . . . . . . . . 112

4.11 Summary of Costs and Revenues of the Olympic Games . . . . . . . 114 


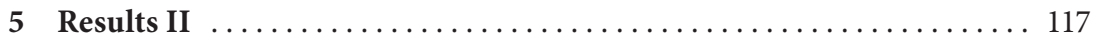

5.1 Revenue Corridors by OCOG Category $\ldots \ldots \ldots \ldots \ldots \ldots \ldots \ldots$

5.2 Expenditure Corridors by OCOG Category $\ldots \ldots \ldots \ldots \ldots \ldots \ldots$

5.3 Non-OCOG Cost Corridors at Olympic Games ............. 134

5.4 Non-OCOG Cost Corridors at Olympic Winter Games ........ 138

5.5 Summary of Costs and Revenues of Olympic Games

Seperated by Categories ........................... 141

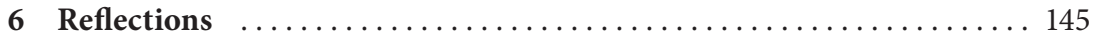

6.1 Theoretical Explanations for Olympic Cost Overruns .......... 145

6.1.1 The Neo-Institutionalism Theory and Cost/Revenue Overruns ............................... 147

6.1.2 Auction Theory: The Winner's Curse .............. 154

6.1.3 Public Interest Theory vs Chicago Theory: Market Regulation to Favour Public Interest . . . . . . . 155

6.1.4 Evolution Theory and Planning Fallacy Theory ......... 156

6.2 The Evolution of Olympic Budgets and their Economic

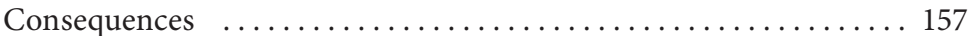

6.2.1 Evolution of Olympic Budgets $\ldots \ldots \ldots \ldots \ldots \ldots \ldots \ldots \ldots$

6.2.2 Economic Consequences: Cost Overruns, Revenue Overruns and Deficit $\ldots \ldots \ldots \ldots \ldots \ldots . \ldots 160$

6.3 Practical Recommendations to Reduce Cost Overruns ......... 162

6.4 Summary and Outlook $\ldots \ldots \ldots \ldots \ldots \ldots \ldots \ldots \ldots \ldots \ldots$

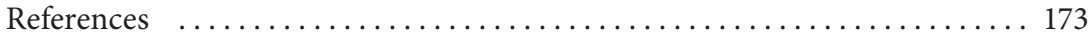




\section{Executive Summary}

The Olympic Games are the largest worldwide multi-sport event and are a significant and complex undertaking. More than 300 projects in distinct industries/ branches and different communities/cities need to be coordinated, often involving more than 50 stakeholders. The resources to organise the event and finance new or renovate/upgrade existing infrastructure come from different bodies, different levels of government, private entities and external investments into the local economy.

The scale of attention and visibility, combined with the uniqueness of the task, have inevitably provoked many discussions about the costs and benefits of such an event, and how to assess them carefully. Part of this conversation has been a recurring focus on the cost overruns ${ }^{1}$ of the Games and how they compare with the original estimates. This debate cannot take place without also looking at the revenues that finance a substantial part of the event and the benefits of the event, which are often intangible.

The objective of this study is to investigate the cost and revenue overruns of Olympic Games ${ }^{2}$ from Sydney 2000 to PyeongChang 2018, as the size and organisational

1 Cost overruns are "the amount by which the actual cost exceeds the budgeted, estimated or target cost” (BusinessDictionary, n.d. a).

2 Since host cities are committed to hosting the Paralympic Games together with the Olympic Games, the costs and revenues taken on board in this study encompass the Paralympic Games as well, even though for the sake of brevity we write "Olympic Games". 
dimension (number of athletes, venues and events) have been relatively constant for that period and provide the best overview of how the Games are managed today.

To provide a base for future host cities, we concentrated our research on the core Olympic costs and revenues. This means we evaluated the development of the expenditure and revenues of the Organising Committees for the Olympic Games (OCOGs), which covers the operations of the event, and the investment of public money for the main Olympic venues (non-OCOG budget).

In addition to these two budgets, host countries, regions or cities often use the Olympic Games as an opportunity to carry out some of their long-term development projects, linked to urban renewal, transport and infrastructure for example, that are often not necessarily needed to stage the Games. This makes the criteria for considering what the actual cost of the Olympic Games is vary widely depending on where they are being organised, the period of the preparation and who is compiling the expenditures (government bodies, independent studies, academic research, media, etc.). These non-Olympic general development projects also have cost overruns, and these are notably often mentioned in media reports. However, these projects have not been considered for the purpose of this study as they are not needed to stage the Games.

This study also shows why attempts to come up with and compare overall capital costs for different Olympic Games editions are misleading. There are many public authorities and private investors involved, which makes it extremely difficult to find all project data from the candidature phase eight years before the Games ( $t-8)$ until Games time ( $\mathrm{t}$ ). If during this period any data are left out, cost overrun calculations will be like comparing apples and oranges.

The four main findings of our study were as follows:

1. For all 10 Games editions, we found that the costs of organising the Olympic Games (OCOG budget) are usually covered by revenues, which are almost entirely private resources plus the International Olympic Committee (IOC)'s contribution.

2. The OCOGs usually significantly overran their expenditures during the first few years, but then all OCOGs managed to save during the last two years and all of them finally balanced the budget or even generated a profit.

3. All Games underestimated their revenues and had revenue overruns.

4. The core Olympic capital investments considered in this study show cost overruns, but they are similar to the cost overruns of other (non-sporting) mega projects. 
Methodologically, we must differentiate between three budgets:

- the expenditures and revenues of the OCOGs, because they are the centre of Olympic Games organisation;

- Olympic-related capital investments on venues, which are needed to stage the Olympic Games. We were very careful to display homogenised data by using the respective GDP deflators and construction price indices to consider inflation, and an average exchange rate to consider different currencies;

- non-Olympic infrastructure projects (airports, metro, roads, urban parks) for the long-term benefit of the city and region that are not required for the organisation of the Games, but which are often mistakenly mixed into the Games-related costs. These projects have not been considered in our study.

All results in this study are presented as percentages because the aim is to reveal the variations of the OCOG expenditures and revenues and the non-OCOG capital investments over time from bidding (t-8) to staging the Olympic Games (t). Shown in percentages, the absolute value of the costs is unnecessary and has no influence on the comparisons. Furthermore, the use of percentages has allowed this study to compare and contrast the 10 editions of the Olympic Games that were analysed. This has been done by categorising the expenditures and revenues of the OCOG and building a fixed set of Olympic venues (hereafter referred to as a "basket of venues") that are definitely needed and consistent across every Games edition for the non-OCOG capital investments. This "basket of venues" plays a similar role to the "basket of consumer goods" for tracking purchasing power (cost variation over time) in an economy. It also allows for a coherent comparison between different editions of the Games. Finally, the selection of venues represents a variety of capital investments and thus contains different potentials for cost overruns. The diversity of the basket ensures that the cost variations of these representative investments are relatively the same as those that a larger or full sample of all Olympic investments would create.

The "core" basket reflects with high probability the "performance" of the full basket with some conservative distortions due to the fact that the "core" basket represents the highest level of project size and complexity. However, given that we have over-proportionally considered more venues financed using public money, the cost overruns are probably higher in our study than for the overall investments. Thus we take a conservative estimation here. The basket contains the Olympic Stadium, Olympic Village, IBC/MPC, swimming pool, multipurpose hall, velodrome, ski jumping hill, sliding centre and ice stadium. In other words, it can reasonably be assumed that almost all capital investments in sports venues were publicly financed 
anyhow and that private investors are less likely to accept (or manage) cost overruns than public fund providers. Overall, the rate of cost overruns should be higher for public funding and, by often not including the share of private investment in this study, we are taking a conservative approach, as the overruns would tend to be reduced otherwise.

Tables 1 and 2 summarise the main findings. For all 10 Games editions analysed, we found that the operational costs of organising the Olympic Games (OCOG budget) are usually covered by revenues, which are almost entirely private resources and the IOC's contribution, which stems from the sale of media rights and international sponsorships.

Table 1 Total cost overruns/ underruns from the Olympic Games

\begin{tabular}{lccccc}
\hline & Sydney 2000 & Athens 2004 & Beijing 2008 & London 2012 & Rio 2016 $^{\mathbf{3}}$ \\
\hline $\begin{array}{l}\text { OCOG } \\
\text { Revenue }\end{array}$ & $72 \%$ & $51 \%$ & $8 \%$ & $50 \%$ & N/A \\
\hline $\begin{array}{l}\text { OCOG } \\
\text { Expenditure }\end{array}$ & $51 \%$ & $30 \%$ & $4 \%$ & $48 \%$ & N/A \\
\hline \begin{tabular}{l} 
Non-OCOG \\
\hline
\end{tabular} & $56 \%$ & $29 \%{ }^{4}$ & N/A & $43 \%$ & N/A \\
\hline
\end{tabular}

Table 1 shows the percentage change in the budget estimated eight years before the Games to the final budget. It clearly shows that, relatively, revenues are underestimated more than costs. In particular, for Sydney 2000 and Athens 2004, OCOG revenues were used to balance the public costs of the host cities. A small final profit was then shared between the National Olympic Committees (NOCs), the city and the IOC, in accordance with the Host City Contract. PyeongChang 2018 is the first host that can keep its profit (US\$ 55m) entirely, without a share going to the IOC. This study will have considerable information about the "N/A" fields; however, for this table we were not able to produce a final figure due to a missing final budget from $(\mathrm{t})$.

3 The accounts for the Olympic Games Rio 2016 have not yet been formally closed at the time of our book, so there are no final numbers available.

4 Additional venues were considered. 
The "basket of venues" used to measure the non-OCOG budgets demonstrates that the Olympic Games between 2000 and 2012 caused cost overruns from 29\% to 56\%. Rio 2016 managed to reduce the costs for the Olympic Stadium and its multipurpose hall, which was partly renovated for the Pan American Games in 2007. The public share of costs for the six core Olympic venues in Rio that are considered in our "basket" look low in comparison to media reports; however, there may have been large cost overruns for non-Olympic general infrastructural enhancements. The non-OCOG finances of Rio 2016 are not finalised, thus we have no comparable figure in Table 1.

Table 2 Total cost overruns/underruns from the Olympic Winter Games

\begin{tabular}{lccccc}
\hline & $\begin{array}{c}\text { Salt Lake } \\
\text { City 2002 }\end{array}$ & $\begin{array}{c}\text { Turin } \\
\mathbf{2 0 0 6}\end{array}$ & $\begin{array}{c}\text { Vancouver } \\
\mathbf{2 0 1 0}\end{array}$ & $\begin{array}{c}\text { Sochi } \\
\mathbf{2 0 1 4}\end{array}$ & $\begin{array}{c}\text { Pyeong- } \\
\text { Chang 2018 }^{\mathbf{5}}\end{array}$ \\
\hline $\begin{array}{l}\text { OCOG } \\
\text { Revenue }\end{array}$ & $119 \%$ & N/A & $12 \%$ & $-3 \%$ & $27 \%$ \\
\hline $\begin{array}{l}\text { OCOG } \\
\text { Expenditure }\end{array}$ & $114 \%$ & $58 \%$ & $12 \%$ & $-6 \%$ & $24 \%$ \\
\hline Non-OCOG & $28 \%$ & $20 \%$ & $13 \%$ & $178 \%$ & N/A \\
\hline
\end{tabular}

The cost and revenue development for the Olympic Winter Games shows a similar pattern. Salt Lake City 2002 experienced major changes in its OCOG budget, while Vancouver 2010's variation was much lower. For all Olympic Winter Games editions, the OCOGs also managed to balance the expenditures and revenues. A key result is that over the 10 Olympic Games evaluated, the OCOGs always managed to end up with either a balanced budget or a surplus.

The non-OCOG cost overruns of Salt Lake City 2002, Turin 2006 and Vancouver 2010 were at a moderate $13-28 \%$. The outlier was Sochi 2014 with 178\%. Other than Sochi 2014, PyeongChang 2018 seems to have managed a reduction of its total costs. One year ahead of the Games the estimates were below the projections made eight years before. However, while the OCOG budget ended with a profit, we do not yet have the final budget for investments, which explains the N/A for these Games.

5 The accounts for the Olympic Winter Games PyeongChang 2018 have not yet been formally finalised at the time of our book, so there are no final numbers for non-OCOG budget. 


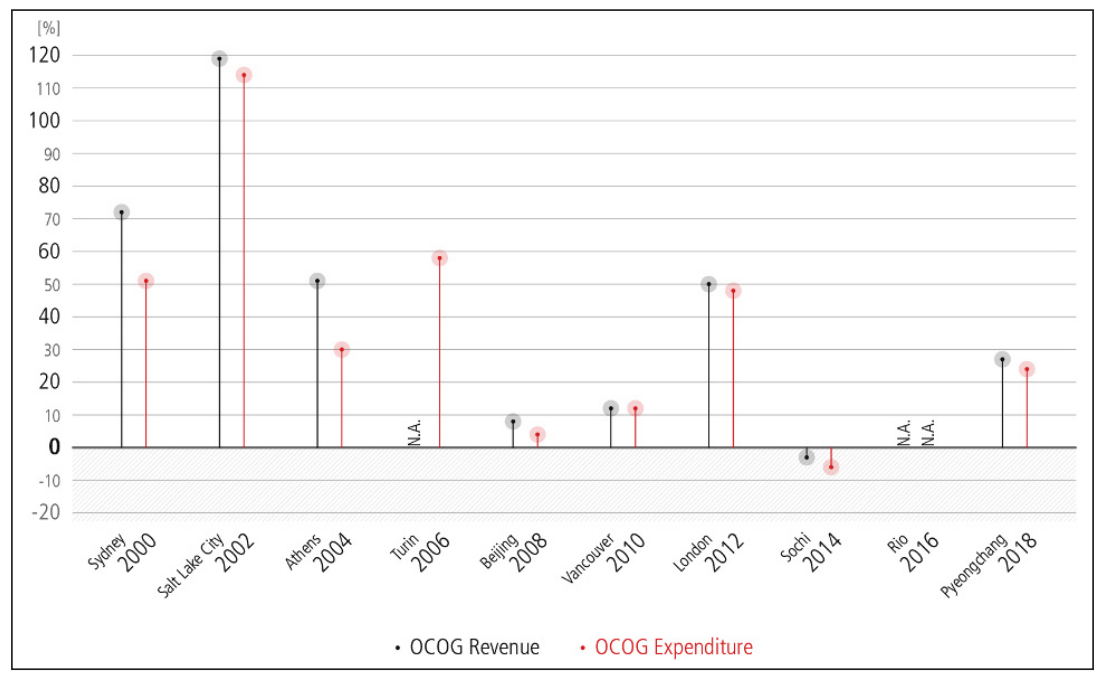

Fig. 1 Total cost overruns/underruns of the Organising Committees for the Olympic Games for which final numbers are available at the time of our book

Figure 1 compares all the 10 Games editions used in this study. It shows that the percentage of cost and revenue overruns became lower after Turin 2006, which indicates better planning and management. For OCOG revenues, all OCOGs except Rio 2016 (not definitively confirmed) and Sochi 2014 achieved a revenue overrun against their projection eight years before. The expectations of all other eight cities were greatly exceeded. According to the recent report by PyeongChang 2018 to the IOC Session in Buenos Aires on 8 October 2018, the OCOG achieved a surplus of US\$ 55m. Sydney 2000 had the highest difference (72\%) for the Olympic Games; and Salt Lake City 2002, with 119\%, was the highest for the Olympic Winter Games.

Eight out of the 10 OCOGs analysed also had expenditure overruns. Rio 2016 (according to the data we have) managed to keep up with the prognosis in its Candidature File, and Sochi 2014 spent even less than predicted due to the high inflation during the time of preparation.

Another finding in this study is that the first few years of an OCOG's lifecycle is the period in which they significantly overrun their expenditures. However, all OCOGs achieved savings during the last two years, thereby balancing the budget. An important contribution to balancing the budget is the high revenue overruns. This can be explained by the ever-increasing revenues of the Olympic Movement and the often conservative revenue estimate in the candidature files. 
Regarding capital investments (Fig. 2), this study shows that core Olympic investments (non-OCOG budgets) have cost overruns similar to other mega projects. However, we demonstrated that some Olympic venues were able to reduce projected costs while others had severe overruns. In our discussion, we explain other reasons.

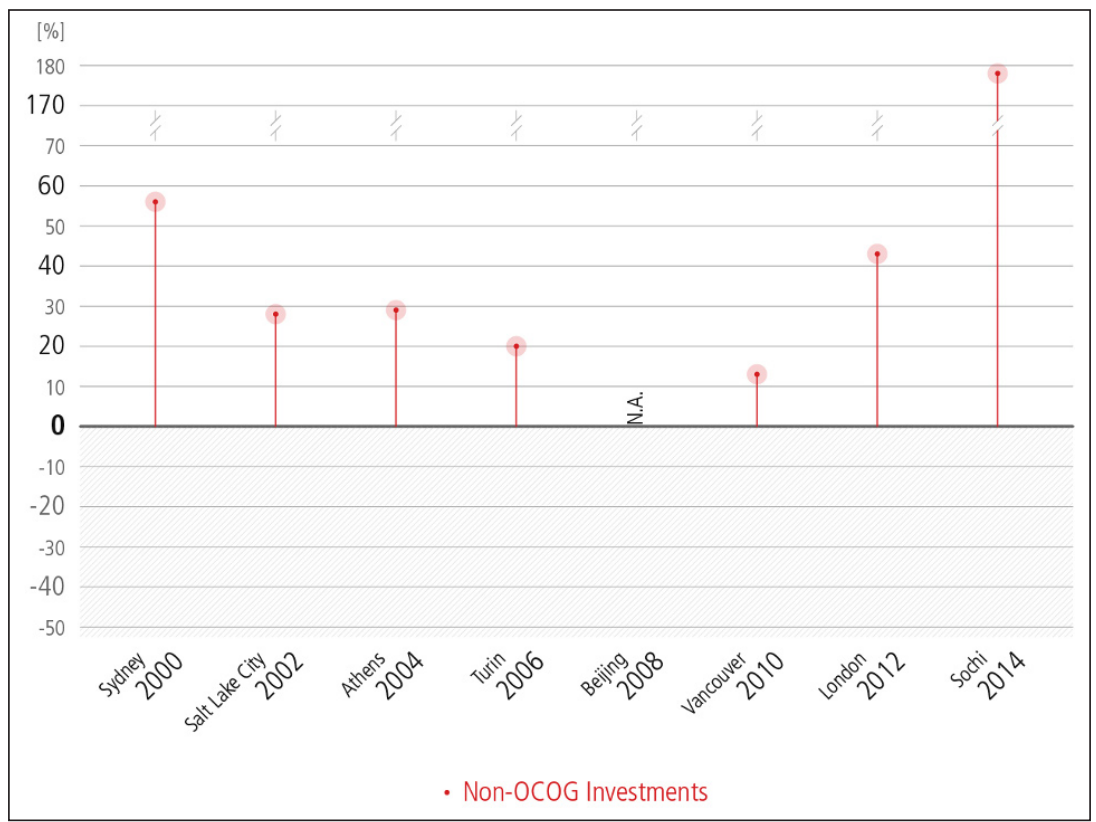

Fig. 2 Total cost overruns of the non-OCOG budgets for which final numbers are available at the time of our book

Although it was possible to conclude that the capital costs of the non-OCOG budget do not present higher overruns than projects in other industries and businesses, this study offers empirical evidence that a comparison of the Games or of Games investments as a whole with other mega projects cannot be reliable and is methodologically and academically questionable because of the following factors:

1. The Olympic Games are unique in their composition of construction (stadium, sewage supply, telecommunications and power plants, airports and villages, 
parks, etc.) and societal projects (education programmes, nation building and tourism advertisement, etc.), and thus no other branch can be compared to them.

2. The Olympic Games and all construction projects are unique for each country - thus making it impossible to compare the construction of a stadium in Brazil with one in Australia - due to different political and economic systems and public support levels, or national financial crises and inflation.

Our literature review provides a complete picture of reasons for cost overruns in mega projects and at the Olympic Games. The results show systematically that cost/ expenditure/revenue changes per Games edition, per expenditure/revenue category and per infrastructure. Thus, we illustrate that at the same Games edition, different categories have different overruns. In most cases we were able to give logical explanations as to why these happened.

Overall in our study, we have been able to logically and theoretically explain which patterns caused cost overruns. These are not explained in the executive summary owing to their complexity. However, one of the main reasons for OCOG and non-OCOG cost overruns is the change of scope relating to expenses that were not planned at the beginning or that changed in the preparatory process, both on the side of the OCOG budget and for non-OCOG costs. Another reason is time pressure, which arises when the construction of venues begins too late.

We end with 18 recommendations for the IOC, OCOGs, host cities and public authorities:

R1 Host cities need to receive earlier guidance about the capital investments required for the Games.

R2 The IOC should alleviate pressure on cities during the bidding stage in order to reduce the risks of a "winner's curse" (i.e. overestimating their benefits).

R3 The IOC should work against strategic low-cost estimates to protect the taxpayer and should ensure that figures given are as realistic as possible.

R4 The host city should start constructing the required infrastructure as soon as the Olympic Games are awarded.

R5 The IOC should maintain responsibility for the agreed structural changes and enforce its overarching power to avoid unnecessary investments.

R6 The IOC should ensure that the host city's decision-makers have extensive plans regarding the funding of each "required" Olympic investment.

R7 The IOC should ensure that infrastructure costs that would have been incurred in any case are not counted in the "Olympic" costs. 
R8 Cost and revenue projections should be estimated the Games-time value. Inflation must be accounted for on the basis of consumer price indices and construction price indices.

R9 The host government should appoint a professional executive leadership.

R10 The host government should report to the parliament annually on the estimates of non-OCOG costs.

R11 Workforce and administration need to be budgeted with higher contingencies.

R12 Legacy transformation costs need to be planned and budgeted from the very beginning.

R13 The host city and the IOC should insist on maximising legacy through capacity reduction and post-event planning.

R14 The IOC should undertake measures together with the host government with a view to increasing transparency in relation to budget, cost and revenue changes.

R15 The delivery authority has to maintain a clear focus on the need for timely decision-making individually and collectively on an Olympic programme, in particular when there are multiple stakeholders and interests.

R16 The IOC should create a consistent financial category system to detect changes during and between Games.

R17 A first serious budget estimate should be made only once there is a valid overview of the overall project.

R18 The IOC should ensure that the Organising Committee conducts, in collaboration with relevant partners, a cost-benefit analysis before and after the Olympic Games. 


\section{List of Abbreviations}

ATHOC Athens 2004 Organising Committee for the Olympic Games

B.C. British Columbia

BOCOG Beijing Organising Committee for the Games of the XXIX Olympiad

COJOPR Rio 2016 Organising Committee for the Olympic Games

COV cost overrun

DCMS Department for Culture, Media and Sport

EXPO Exposition Mondiale

FIFA Fédération Internationale de Football Association

FIS Fédération Internationale de Ski

GAO Government Accountability Office

GDP gross domestic product

IBC International Broadcasting Centre

IF International Sports Federation

IOBE Foundation for Economic \& Industrial Research

IOC International Olympic Committee

LOCOG London Organising Committee of the Olympic Games and Paralympic Games

MPC Main Press Centre

NOC National Olympic Committee

NSW New South Wales

OCA Olympic Coordination Authority

OCOG Organising Committee for the Olympic Games

ODA Olympic Delivery Authority

OSC Olympic Studies Centre

OSCC Olympic Security Demand Centre

PIP Public Investment Programme

POCOG PyeongChang Organising Committee for the 2018 Olympic \& Paralympic Winter Games 
PPP Public Private Partnership

RIOU Russian International Olympic University

ROV revenue overrun

SLOC Salt Lake Organising Committee

SOCOG Sydney Organising Committee for the Olympic Games

SOOC Sochi 2014 Organising Committee

TOROC Turin Organising Committee

USOC United States Olympic Committee

VANOC Vancouver Organising Committee for the 2010 Olympic and Paralympic Winter Games

YPEHODE Ministry of Environment, Physical Planning and Public Works 


\section{List of Tables}

Table 1 Total cost overruns/ underruns from the Olympic Games ...... XII

Table 2 Total cost overruns/underruns from the Olympic Winter Games ................................... XIII

Table 3 Cost overruns in infrastructure projects (April $1992-$

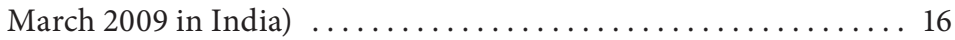

Table 4 Cost overruns in rail projects in different countries $\ldots \ldots \ldots \ldots 17$

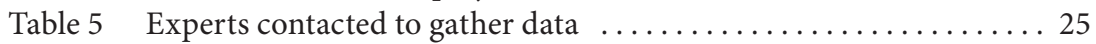

Table 6 Comparison of estimated and real inflation of the total OCOG

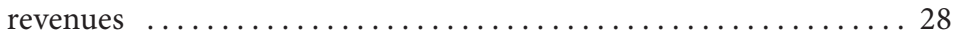

Table 7 Definition of "baskets" for the non-OCOG budget $\ldots \ldots \ldots \ldots 32$

Table 8 Percentage of public costs of the total costs of Olympic

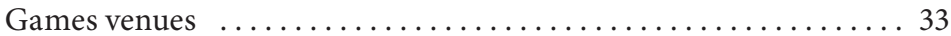

Table 9 Percentage of public costs of the total costs of Olympic

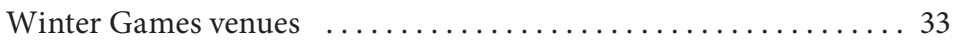

Table 10 Construction Price Index at Olympic host nations $\ldots \ldots \ldots \ldots 35$

Table 11 GDP deflators in Olympic host nations $\ldots \ldots \ldots \ldots \ldots \ldots \ldots$

Table 12 Exchange rates in the Olympic Games countries t- 8 to t . ...... 37

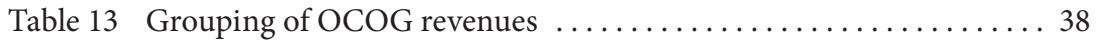

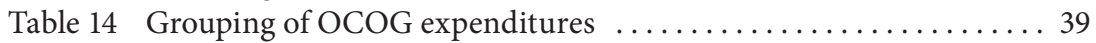

Table 15 Grouping of non-OCOG investments $\ldots \ldots \ldots \ldots \ldots \ldots \ldots 40$

Table 16 Comparison of cost estimates for Sydney 2000 pre-bidding . .... 45

Table 17 SOCOG revenue evolution of estimates and final $\ldots \ldots \ldots \ldots .47$

Table 18 SOCOG expenditure evolution of estimates and final ......... 49

Table 19 Sydney 2000 non-OCOG costs evolution of estimates and

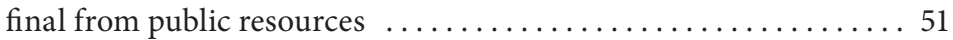

Table 20 SLOC revenue evolution of estimates and final $\ldots \ldots \ldots \ldots \ldots 54$

Table 21 SLOC expenditure evolution of estimates and final $\ldots \ldots \ldots \ldots 56$ 
Table 22 Salt Lake City 2002 non-OCOG cost evolution of estimates and final from public resources $\ldots \ldots \ldots \ldots \ldots \ldots \ldots . \ldots \ldots$

Table 23 ATHOC revenue evolution of estimates and final $\ldots \ldots \ldots \ldots 63$

Table 24 ATHOC expenditure evolution of estimates and final . . . . . 65

Table 25 Athens 2004 non-OCOG cost evolution of estimates and final

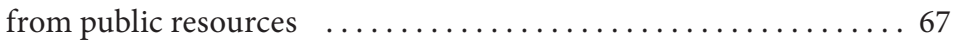

Table 26 TOROC revenue evolution of estimates $\ldots \ldots \ldots \ldots \ldots \ldots \ldots \ldots 72$

Table 27 TOROC expenditure evolution of estimates and final . . . . . . . 74

Table 28 Turin 2006 non-OCOG cost evolution of estimates and final

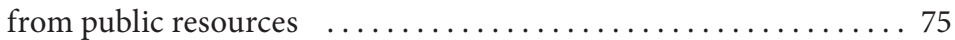

Table 29 BOCOG revenue evolution of estimates and final $\ldots \ldots \ldots \ldots . .77$

Table 30 BOCOG expenditure evolution of estimates and final . . . . . . 79

Table 31 VANOC revenue evolution of estimates and final $\ldots \ldots \ldots \ldots . \ldots 81$

Table 32 VANOC expenditure evolution of estimates and final $\ldots \ldots \ldots 83$

Table 33 Vancouver 2010 non-OCOG cost evolution of estimates and

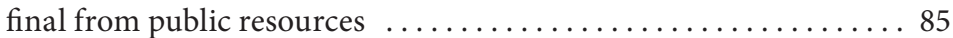

Table 34 LOCOG revenue evolution of estimates and final $\ldots \ldots \ldots \ldots . . .90$

Table 35 LOCOG expenditure evolution of estimates and final . . . . . . 99 92

Table 36 London 2012 non-OCOG evolution of estimates and final

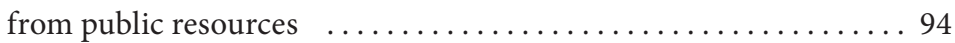

Table 37 SOOC revenue evolution of estimates and final $\ldots \ldots \ldots \ldots \ldots$

Table 38 SOOC expenditure evolution of estimates and final . . . . . . . 100

Table 39 Sochi 2014 non-OCOG cost evolution of estimates and final

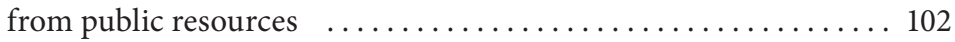

Table 40 COJOPR revenue evolution of estimates $\ldots \ldots \ldots \ldots \ldots \ldots \ldots$

Table 41 COJOPR expenditure evolution of estimates . . . . . . . . . . 107

Table 42 POCOG revenue evolution of estimates and final total . . . . . . . 109

Table 43 POCOG expenditure evolution of estimates and final total . . . . 111

Table 44 PyeongChang 2018 non-OCOG cost evolution of estimates from public resources $\ldots \ldots \ldots \ldots \ldots \ldots \ldots \ldots \ldots \ldots \ldots \ldots$

Table 45 Total cost and revenue overruns/underruns for the Olympic

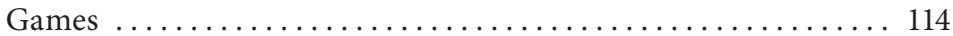

Table 46 Total cost and revenue overruns/underruns for the Olympic Winter Games ......................... 114

Table 47 Olympic Games estimated and final revenues -

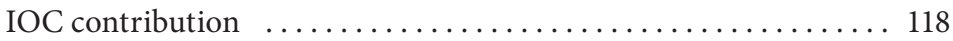

Table 48 Olympic Games estimated and final revenues -

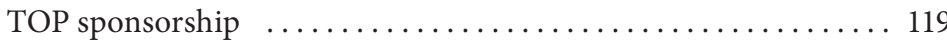


Table 49 Olympic Games estimated and final revenues national sponsorship

Table 50 Olympic Games estimated and final revenues ticket sales

Table 51 Olympic Games estimated and final revenues -

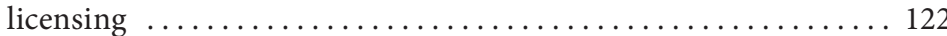

Table 52 Olympic Games estimated and final revenues -

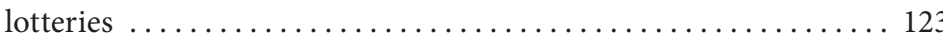

Table 53 Olympic Games estimated and final revenues donations

Table 54 Olympic Games estimated and final revenues -

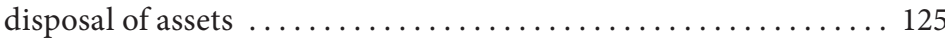

Table 55 Olympic Games estimated and final revenues subsidies

Table 56 Olympic Games estimated and final revenues -

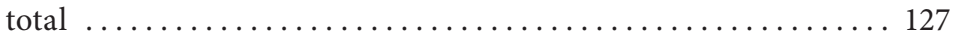

Table 57 Olympic Games estimated and final expenditures -

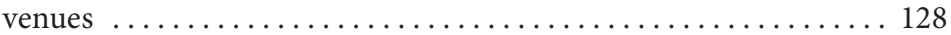

Table 58 Olympic Games estimated and final expenditures -

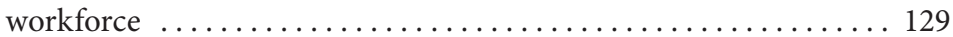

Table 59 Olympic Games estimated and final expenditures -

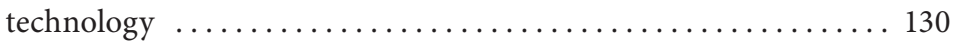

Table 60 Olympic Games estimated and final expenditures -

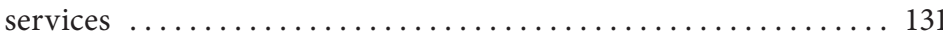

Table 61 Olympic Games estimated and final expenditures marketing \& events

Table 62 Olympic Games estimated and final expenditures administration \& coordination

Table 63 Olympic Games estimated and final expenditures total .......................................... 134

Table 64 Olympic Games estimated and final non-OCOG costs -

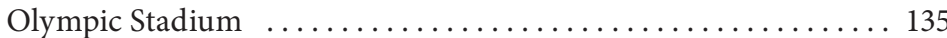

Table 65 Olympic Games estimated and final non-OCOG costs -

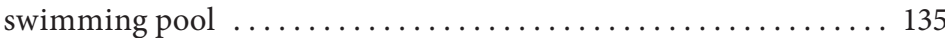

Table 66 Olympic Games estimated and final non-OCOG costs multipurpose hall ............................. 136

Table 67 Olympic Games estimated and final non-OCOG costs velodrome 
Table 68 Olympic Games estimated and final non-OCOG costs -

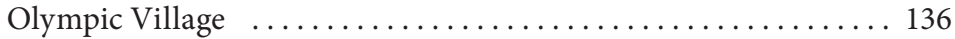

Table 69 Olympic Games estimated and final non-OCOG costs total ........................................ 137

Table 70 Olympic Winter Games estimated and final non-OCOG costs -

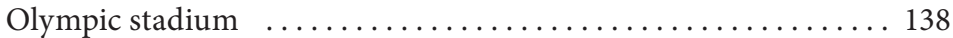

Table 71 Olympic Winter Games estimated and final non-OCOG costs -

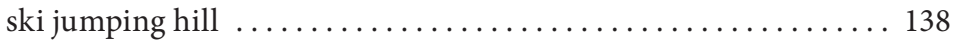

Table 72 Olympic Winter Games estimated and final non-OCOG costs -

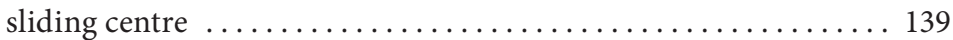

Table 73 Olympic Winter Games estimated and final non-OCOG costs ice stadium .................................. 139

Table 74 Olympic Winter Games estimated and final non-OCOG costs Olympic Village ............................... 140

Table 75 Olympic Winter Games estimated and final non-OCOG costs IBC/MPC ................................. 140

Table 76 Olympic Winter Games estimated and final non-OCOG costs total ....................................... 141

Table 77 Principal-agent relations in the bidding process for a mega sports event 


\section{List of Figures}

Fig. 1 Total cost overruns/underruns of the Organising Committees for the Olympic Games for which final numbers are available at the time of our book $\ldots \ldots \ldots \ldots \ldots \ldots \ldots \ldots \ldots \ldots \ldots \ldots$ XIV

Fig. 2 Total cost overruns of the non-OCOG budgets for which final numbers are available at the time of our book ............. XV

Fig. 3 Number of participating countries in the Olympic Games from 1896 to 2016 .............................. 3

Fig. 4 Number of sports at the Olympic Games from 1896 to 2016 ..... 4

Fig. 5 Number of participating athletes at the Olympic Winter Games from 1988 to 2018 ......................... 4

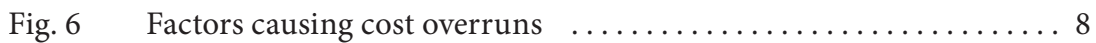

Fig. 7 Costs EXPO 2015 in billions of euros announced by different media . . 24

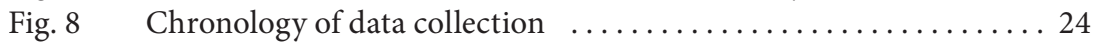

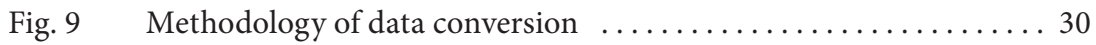

Fig. 10 Organisations involved in the Sydney 2000 Olympic Games .... 45

Fig. 11 SOCOG revenue evolution of estimates and final $\ldots \ldots \ldots \ldots 48$

Fig. 12 SOCOG expenditure evolution of estimates and final ........ 50

Fig. 13 Sydney 2000 non-OCOG cost evolution of estimates and final

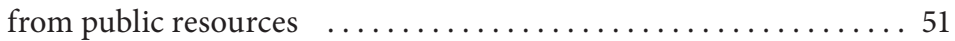

Fig. 14 Total direct cost for projects and activities related to planning and staging the 2002 Olympic and Paralympic Winter Games

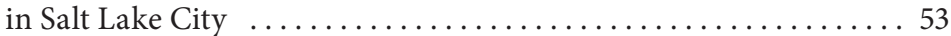

Fig. 15 SLOC revenue evolution of estimates and final $\ldots \ldots \ldots \ldots \ldots 55$

Fig. 16 SLOC expenditure evolution of estimates and final .......... 57

Fig. 17 Salt Lake City 2002 non-OCOG cost evolution of estimates and final from public resources $\ldots \ldots \ldots \ldots \ldots \ldots \ldots \ldots$

Fig. 18 Expenditure for the preparation of the 2004 Olympic Games

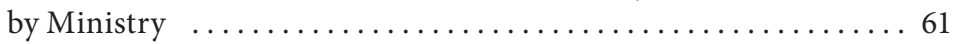


Fig. 19 ATHOC revenue evolution of estimates and final $\ldots \ldots \ldots \ldots 64$

Fig. 20 ATHOC expenditure evolution of estimates and final $\ldots \ldots \ldots 65$

Fig. 21 Athens 2004 non-OCOG cost evolution of estimates and final from public resources $\ldots \ldots \ldots \ldots \ldots \ldots \ldots \ldots$

Fig. 22 TOROC revenue evolution of estimates $\ldots \ldots \ldots \ldots \ldots \ldots \ldots 73$

Fig. 23 TOROC expenditure evolution of estimates and final ........ 74

Fig. 24 Turin 2006 non-OCOG cost evolution of estimates and final

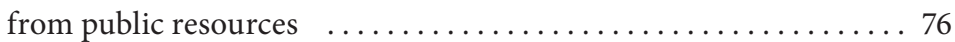

Fig. 25 BOCOG revenue evolution of estimates and final $\ldots \ldots \ldots \ldots .78$

Fig. 26 BOCOG expenditure evolution of estimates and final $\ldots \ldots \ldots 79$

Fig. 27 VANOC revenue evolution of estimates and final $\ldots \ldots \ldots \ldots . \ldots 2$

Fig. 28 VANOC expenditure evolution of estimates and final $\ldots \ldots \ldots 84$

Fig. 29 Vancouver 2010 non-OCOG cost evolution of estimates and final from public resources $\ldots \ldots \ldots \ldots \ldots \ldots \ldots . \ldots . \ldots . \ldots 6$

Fig. 30 Authorities/Organisations involved in delivering and controlling the Olympic Games 2012 ................ 87

Fig. 31 Funding for the Olympic and Paralympic Games in London 2012 .. 88

Fig. 32 LOCOG revenue evolution of estimates and final $\ldots \ldots \ldots \ldots 91$

Fig. 33 LOCOG expenditure evolution of estimates and final ......... 93

Fig. 34 London 2012 non-OCOG cost evolution of estimates and final

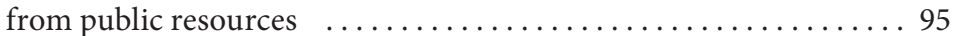

Fig. 35 Financing of the Winter Games Sochi $2014 \ldots \ldots \ldots \ldots \ldots \ldots . \ldots 97$

Fig. 36 SOOC revenue evolution of estimates and final ............ 99

Fig. 37 SOOC expenditure evolution of estimates and final $\ldots \ldots \ldots \ldots 100$

Fig. 38 Sochi 2014 non-OCOG cost evolution of estimates and final

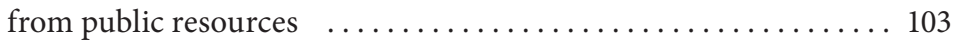

Fig. 39 POCOG revenue evolution of estimates and final total $\ldots \ldots \ldots 110$

Fig. 40 POCOG expenditure evolution of estimates and final total .... 112

Fig. 41 PyeongChang 2018 non-OCOG cost evolution of estimations from public resources $\ldots \ldots \ldots \ldots \ldots \ldots \ldots \ldots \ldots . \ldots \ldots \ldots$

Fig. 42 OCOG revenues and expenditures for the Olympic Games and Olympic Winter Games .......................... 115

Fig. 43 Non-OCOG investments for the Olympic Games and Olympic Winter Games ............................... 116

Fig. 44 Cascade of PRINCIPAL-AGENT relations ............... 149

Fig. 45 Number of change orders at SLOC .................... 158

Fig. 46 Budget evolution and financial gap at SLOC (2002) ......... 159

Fig. 47 Volatile budget development at SLOC (2002) .............. 160 


\section{Introduction}

In many countries the interest in the Olympic Games seems to have changed. The media raises the question whether cities will compete to host the Olympic Games in the future (Bull 2016). It is evident that some applicant cities have withdrawn their bids for different reasons. The insecurity about cost overruns and the overall size of costs during the bidding, mixed with political discussions over host government spending of public money (Lundy 2013; Newman 2007) have led to concerns in western societies as regard the benefits of the Olympic Games for the host region (Coakley \& Souza 2013). This explains why many politicians attach the continuation of their bid to a positive public referendum. This is critical because, over the past six years, nearly every referendum has failed (Munich 2013, St. Moritz 2013, Vienna 2013, Kracow 2014, Hamburg 2015, Graubünden 2017, Innsbruck 2017 and Sion 2018) (Bull 2016; Reuters 2014). Some cities even withdrew their bid before they had a referendum because of a lack of public or politicl support (Barcelona 2013, Oslo 2014, Boston 2014, Stockholm 2014, Rome 2016 and Budapest 2017). Consequently, there is an increasing number of cities that are resigning from a bidding process or not entering the bidding process (Könecke \& Nooij 2017).

In this context, the phenomenon of cost overruns is important to raise (Zimbalist 2015). One of the most prominent studies on cost overruns of the Olympic Games is by Flyvbjerg, Stewart \& Budzier (2016), the so-called "Oxford study", in which the authors start thinking about the reasons for cost overruns. The "Oxford study" compared total costs out of operational costs and capital investment costs of Olympic-related infrastructure from the candidature file to the final costs published

(C) The Author(s) 2019

$\mathrm{H}$. Preuß et al., Cost and Revenue Overruns of the Olympic

Games 2000-2018, Event- und Impaktforschung,

https://doi.org/10.1007/978-3-658-24996-0_1 
for the Olympic Games from 1960 to 2016. When looking at the overall economic costs of the Olympic Games for the public, one has, however, to also assess whether the revenues of the Organising Committee for the Olympic Games (OCOG) seem to overrun. Therefore the research we started here is threefold:

1. What are the OCOG cost overruns and cost overruns on other capital investments for the Olympic Games and Olympic Winter Games?

2. What are the OCOG revenue overruns?

3. How can the cost and revenue overruns be best explained?

Cost overruns are "the amount by which the actual cost exceeds the budgeted, estimated or target cost" (Business Dictionary, n. d.). The allegedly rising cost overruns on which the media is reporting are bothering citizens, as a result of which candidate cities have revised their application for the Olympic Games (Oberli 2017).

If cost overruns (COV) are obviously caused by the Olympic Games (preparation, staging and legacy), then we should also observe overruns of the revenues (ROV):

$$
C O V=>k \cdot R O V
$$

That will partly or entirely compensate for (and finance) cost overruns. This is the only way to explain why, despite recurrent cost overruns $\left(\mathrm{C}_{t}>\mathrm{C}_{\mathrm{t}-\mathrm{n}}\right)$ at all Games, some Olympic Games ended up with a deficit while others made a profit. Indeed, starting from an ex-ante balanced Olympic Games budget such as:

$$
C_{t-n}=R_{t-n}
$$

where $C_{t-n}\left(R_{t-n}\right)$ stands for the ex-ante announced cost (revenue) and $C_{t}\left(R_{t}\right)$ for the achieved ex-post cost (revenue) measured in the same year's price index.

Cost overruns should create a deficit since:

$$
C_{t-n}+C O V>R_{t-n}
$$

However, it might not be the case if the OCOG budget or some non-OCOG budget succeeds in collecting more revenues than expected ex-ante, that is:

$$
R O V=R_{t}-R_{t-n}
$$

Then the final outcome (deficit or no deficit) depends on the comparative size of cost overruns and revenue overruns: 
If $R O V \geq \operatorname{COV}(\mathbf{1}) \Rightarrow$ no deficit

If $R O V<\operatorname{COV}(2)=>$ deficit

In other words, an increase in the Olympic Games costs translates itself into higher expenditures for the OCOG, other hosting authorities and enterprises involved, but these additional expenditures should boil down to increased revenues for someone in the local economy (PricewaterhouseCoopers 2018). At the end of the day, hosting the Games may end up in a deficit or not depending on the comparative magnitude of cost overruns and revenue overruns.

There are a number of published articles about cost overruns in the literature, but none about the Olympic Games revenue overruns (at least with such a title). One value added of the present study is to check both.

The objective of this study is to investigate the cost and revenue overruns of the Olympic Games from Sydney 2000 to PyeongChang 2018. This provides a good overview of the Olympic Games as they are managed today. The size of the Olympic Games from Sydney 2000 onwards marks a relative stable size in terms of athletes, venues and events and therefore it is worth comparing and learning from this comparison for future Games. The following tables indicate the relative stability in size regarding the number of athletes, sports and participating nations. These are important to argue why we decided to look only at the Olympic Games from Sydney 2000.

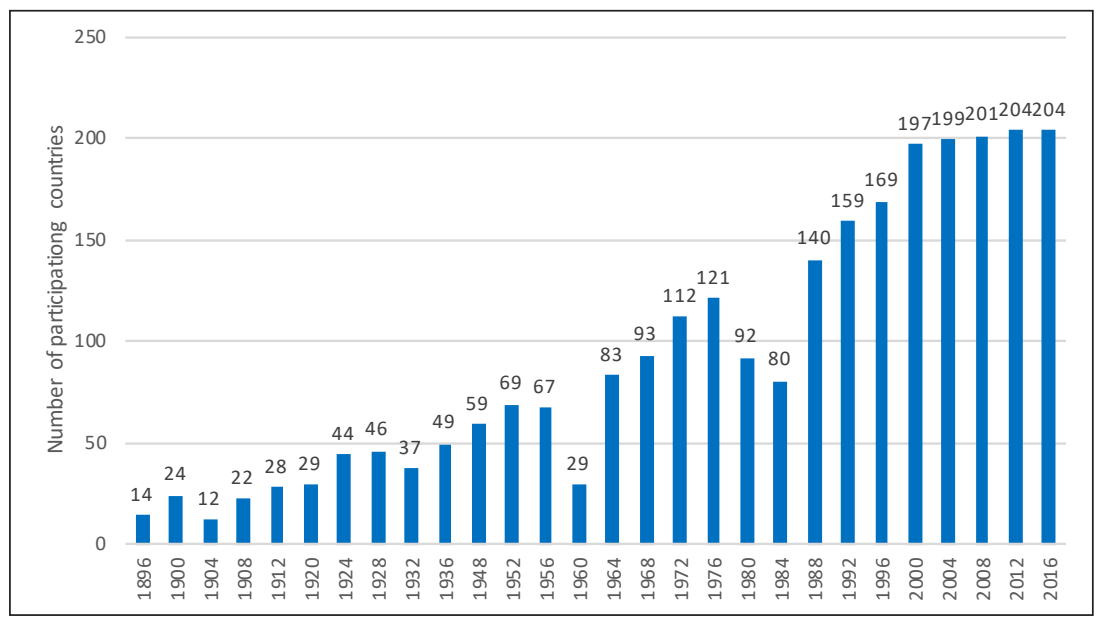

Fig. 3 Number of participating countries in the Olympic Games from 1896 to 2016 Source: IOC (2018) 


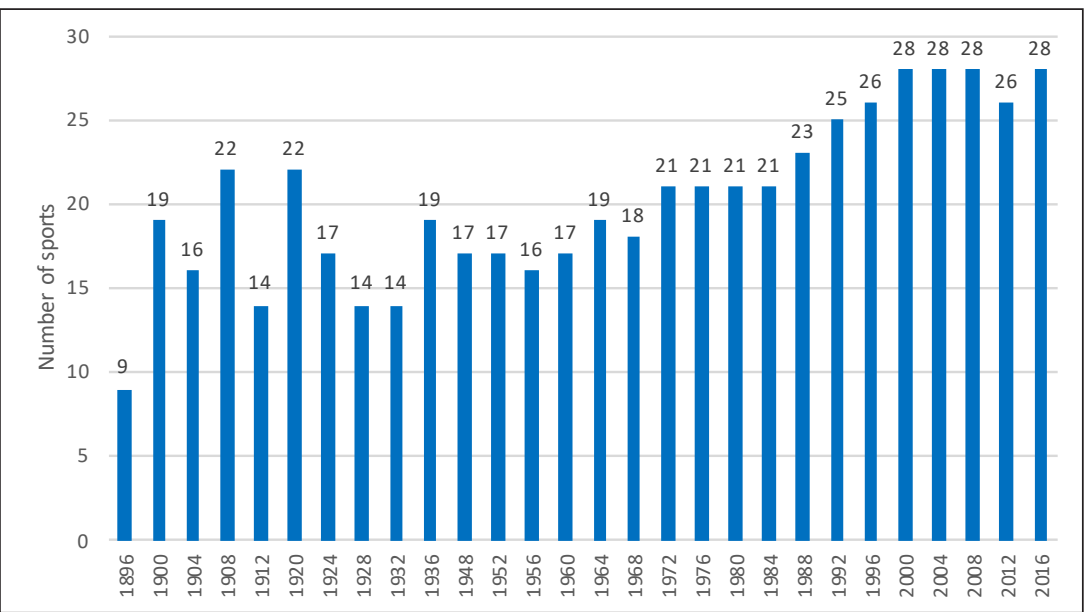

Fig. 4 Number of sports at the Olympic Games from 1896 to 2016

Source: IOC (2018)

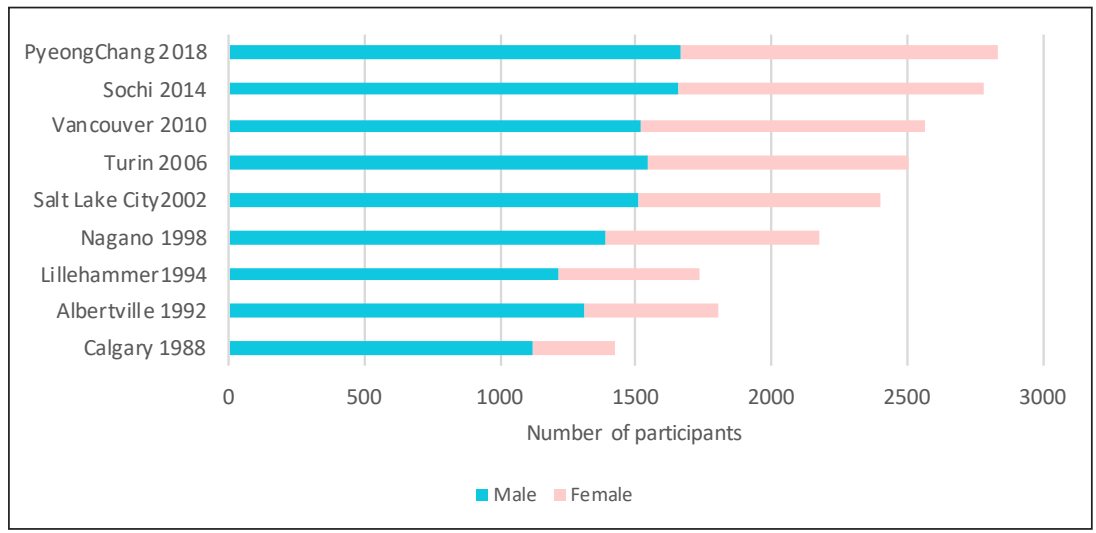

Fig. 5 Number of participating athletes at the Olympic Winter Games from 1988 to 2018

Source: IOC (2018) 
Open Access This chapter is licensed under the terms of the Creative Commons Attribution 4.0 International License (http://creativecommons.org/licenses/by/4.0/), which permits use, sharing, adaptation, distribution and reproduction in any medium or format, as long as you give appropriate credit to the original author(s) and the source, provide a link to the Creative Commons licence and indicate if changes were made.

The images or other third party material in this chapter are included in the chapter's Creative Commons licence, unless indicated otherwise in a credit line to the material. If material is not included in the chapter's Creative Commons licence and your intended use is not permitted by statutory regulation or exceeds the permitted use, you will need to obtain permission directly from the copyright holder.

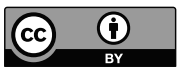




\section{Literature Review}

\subsection{Cost Overruns in General}

\subsubsection{What are Cost Overruns?}

In any investment or other economic project that is going to last over several years between its inception date $t-n$ and its delivery date $t$ on time, the effectively achieved (ex-post) cost in $t$ may happen to be higher than the announced (ex-ante) cost in $t-n$. The longer $n$ is, the higher the risk that such a difference will emerge. This is clearly shown in our literature review in which we listed many reasons for that.

The definition of cost overruns $\mathrm{COV}$ is thus:

$$
\mathrm{COV}=C_{t}-C_{t-n}>0
$$

where $C_{t-n}$ stands for the ex-ante announced cost and $C_{t}$ for the achieved ex-post cost measured in the same year's price index. We have compiled all our data by using the respective GDP deflator. Thus we discounted $C_{t-n}$ at a rate equal to the cumulative inflation rate between $t-n$ and $t$. We explain that in our methodology section.

(C) The Author(s) 2019

H. Preuß et al., Cost and Revenue Overruns of the Olympic

Games 2000-2018, Event- und Impaktforschung, 


\subsubsection{Cost Overruns in Mega Projects and at Olympic Games}

Cost overruns are a common phenomenon for major and mega projects. At bidding stage the International Olympic Committee (IOC) requires a robust analysis of public spending and the resulting economic benefits. Only transparency about cost overruns will help considering the criticism about uncontrollable Olympic Games costs.

Mega sport events are not the only project affected by cost overruns (Cantarelli, Flyvbjerg \& Buhl 2012; Flyvbjerg, Holm \& Buhl 2002; Kostka \& Anzinger 2015; Lundberg, Jepanitsub \& Pyddoke 2011; McKinsey 2015; Odeck 2004; Pickrell 1990; Singh 2010; Sovacool, Enevoldsen, Koch \& Barthelmie 2016). Delays in project implementations and cost overruns have repeatedly been a problem for public sector projects (Satyanarayana 1974). Studies on cost overruns deal primarily with infrastructure projects involving the construction of railways, bridges and tunnels, roads, wind farms and buildings in general (Abdulkadir, Muhammad, Gidado \& Nuruddeen 2017; Abusafiya \& Suliman 2017; Ali, Ali Mangi, Sohu, Jamali \& Kateemullah 2017; Cantarelli et al. 2012; Flyvbjerg 2009; Flyvbjerg, Holm \& Buhl 2002; Kostka \& Anzinger 2015; Lundberg et al. 2011; Odeck 2004; Pickrell 1990; Singh 2010; Sovacool et al. 2016). Infrastructure projects are mainly financed by public money. Nevertheless, literature is lacking on research into organisational projects such as events or the Olympic Games.

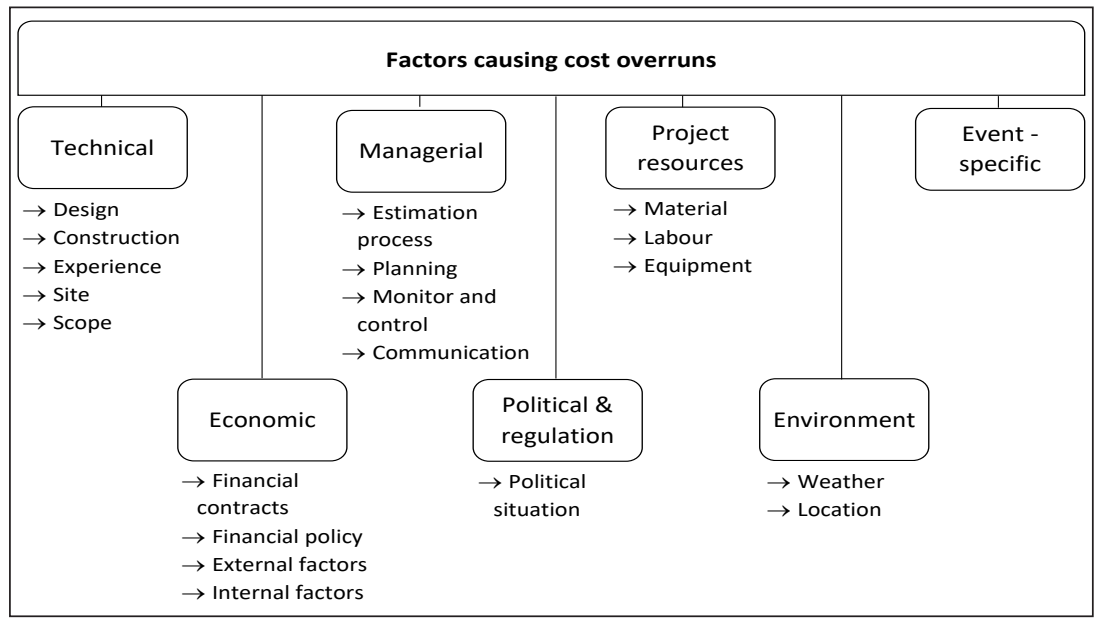

Fig. 6 Factors causing cost overruns

Source: modified according to Abdel-Hafeez et al. (2016) 
The reasons for cost overruns are manifold. The general factors causing cost overruns can be roughly categorised into technical, economic, managerial, political, environmental aspects and project resources (Abdel-Hafeez, El-Attar \& Abdel-Hafez 2016). In addition, these factors may be supplemented by specific event-related factors.

\section{Technically-based cost overruns}

Technically-based cost overruns can be divided into design, construction, experience, site and scope. Changes in the design and bad overviews of drawings for the project are related to design aspects that can lead to cost overruns (Ali, Ali Mangi, Sohu, Jamali \& Kateemullah 2017, 30; Berechman \& Chen 2011; Creedy 2004; Creedy, Skitmore, \& Wong 2010; Flyvbjerg, Bruzelius \& Rothengatter 2003; Le-Hoai, Dai Lee \& Lee 2008; Jackson 2002; Miller \& Lessard 2000; Morris \& Pinto 2004). In addition, construction-related causes, such as poor technical performance, changes or disagreements that occur in the construction period, as well as the technical complexity of projects, or multiple tasks in different fields and delays in the project handover, can lead to cost increases (Abd-Karim, Memon, \& Abdul-Rahman 2013; Alinaitwe, Apolot, \& Tindiwensi 2013; Banaitiene \& Banaitis 2012; Bruzelius, Flyvbjerg \& Rothengatter 1998; Flyvbjerg 2011, 322; Flyvbjerg, Bruzelius \& Rothengatter 2003; Flyvbjerg, Garbuio \& Lovallo 2009; Gajewska, \& Ropel 2011; Kwak, Walewski, Sleeper \& Sadatsafavi 2014; Lu, Luo, Wang, Le \& Shi 2015; Memon, Abdul Rahman \& Abdul Azis 2011; Miller \& Lessard 2000; Morris 1990; Morris \& Pinto 2004; Toh, Ting, Ali, Aliagha, \& Munir 2012; Williams 2003, 2004; Zujo, CarPusic, \& Brkan-Vejzovic 2010). For the Olympic Games the following problems concerning construction could be found: side costs of major construction projects, e.g. the road and parking arrangements around venues and contractors' problems with handling the size of the project (e.g. architect leaves, static problems, iconic venues are expensive to construct, size of the project; National Audit Office 2007a). Another potential cost overrun in the design aspect is the experience in technical terms. Especially in the decision-making phase during the tendering process, the lack of experience and delays in the design and procurement phases are decisive (Alfouzan 2013; Bageis \& Fortune 2009; Banaitiene \& Banaitis 2012; Khodeir \& Hamdy 2015; Mahamid \& Bruland 2011; Shaqour 2014). Another aspect for potential cost overruns is the site. On the one hand, the site conditions can be unpredictable; on the other hand, the organisation of the site can be poor (Shanmuganathan, \& Baskar 2015; Singh 2011). A last factor in the technical area is the scope. This means that additional work has been requested by the owner, the order of the project has changed and there is an inadequate definition of the scope (Ali et al. 2017, 30; Alinaitwe et al. 2013; Berechman \& Chen 2011; Creedy 2004; Creedy, Skitmore, \&Wong 2010; Flyvbjerg 2011, 322; Gajewska, \& Ropel 2011; Gomez Arcila 2012; Halloum \& 
Bajracharya 2012; Khodeir \& Hamdy 2015; Morris 1990; Senouci, Alsarraj, Gunduz \& Eldin 2016, 1; Shaqour 2014). An example for this factor for the Olympic Games is the Atlanta Organising Committee, which forgot to include the space that was needed in the surroundings of the Olympic facilities (warm-up gyms, parklands, offices, etc.). E.g. for Atlanta 1996, the need for warm-up courses, extra parking and the demolition costs of the old Fulton Stadium were not calculated in (ACOG 1994). But also the change in technology and a varying demand for technology might lead to cost overruns for the Olympic Games.

\section{Economically-based cost overruns}

Factors that may cause cost overruns based on economics can be divided into financial contractors, financial policy, external and internal factors. Considering financial contractors they tend to select the lowest price, the lack of experience in contractors and poor contractor management can be responsible for price increases (Abd-Karim et al. 2013; Banaitiene \& Banaitis 2012; Gomez Arcila 2012; Khodeir \& Hamdy 2015; Koushki, Al-Rashied \& Kartam 2005; Le-Hoai, Lee \& Lee 2008; Mahamid \& Bruland 2011; Shanmuganathan \& Baskar 2015; Shaqour 2014; Singh 2011). In addition, bad investment decisions, insufficient funding, methods of financing and payment problems for finished work are the causes of higher costs in the area of financial policy (Abusafiya \& Suliman 2017, 35; Ali et al. 2017, 30; Gomez Arcila 2012; Khodeir \& Hamdy 2015; Koushki, Al-Rashied \& Kartam 2005; Shaqour 2014). We found some evidence regarding financial policy that occurs during the planning phase of the Olympic Games: planning the finance as regards when and how much money needs to be taken from the market and the late founding of or a too small OCOG (regarding the construction control of venues to match Olympic needs). Other cost increases can occur owing to external factors such as changes in the currency exchange rate, foreign companies and subsidies that dominate the construction industry, government policies like laws and regulations and economic instability (Alinaitwe et al. 2013; Ameh, Soyingbe \& Odusami 2010; Khodeir \& Hamdy 2015; Morris 1990; Shaqour 2014; Siemiatycki 2015). In terms of the Olympic Games, it is almost to be expected that changes in exchange rates will occur, and therefore more or less money (in domestic currency) will have to be paid for debts or to international partners, topether with possible changes in interest or inflation rates. Ultimately, in the field of economics, internal factors such as poor contractor management, organisational variables and characteristics of the project and client may lead to cost overruns (Alfouzan 2013; Bageis \& Fortune 2009; Khodeir \& Hamdy 2015; Mahamid \& Bruland 2011; Shaqour 2014). For example, for Barcelona 1992 and Athens 2004, many private land owners increased prices before the construction could start (Botella 1995, 28). Therefore, the stakeholder 
response (in particular to encourage all stakeholders to support the project) has been recognized as an internal factor in the Olympic Games.

\section{Managerially-based cost overruns}

On the managerial side, there are cost overruns in different phases, starting with the estimate process, followed by the planning, the monitoring and control and the communication. During the estimate/planning process, an inaccurate or bad estimate of the final costs, or the use of incorrect or inappropriate methods for estimating costs and the risk of the process can arise (Flyvbjerg et al. 2009; Halloum \& Bajracharya 2012; Jackson 2002; Khodeir \& Hamdy 2015; Mahamid \& Bruland 2011; Shaqour 2014, Vanston \& Vanston 2004, 33). This is complemented by the theory of optimism bias established by Kahneman \& Tversky (1979). “The optimism bias is defined as the difference between a person's expectation and the outcome that follows. If expectations are better than reality, the bias is optimistic; if reality is better than expected, the bias is pessimistic" (Sharot 2011, R941). Problems in estimating the Olympic Games were mainly recorded in these areas:

- the practical examples of Olympic Games can be found in overestimating the size of existing infrastructure and its fit for the Games in the planning stage in terms of limited knowledge about size and scope,

- underestimating the need for accommodation for visitors and the Olympic family (the use of ships as accommodation in Sydney, Athens, London and Sochi; Golden 2013),

- underestimating transport infrastructure and parking space.

After the estimation process, various factors in the planning phase, such as an insufficient project analysis, unsuitable planning and scheduling or changes in the planning and scheduling and also wrong planning can lead to cost overruns (AbdKarim et al. 2013; Al-Jurf \& Beheiry 2010; Alinaitwe et al. 2013; Banaitiene \& Banaitis 2012; Doloi 2013; Khodeir \& Hamdy 2015; Gajewska, \& Ropel 2011; Gomez Arcila 2012; Mahamid \& Bruland 2011; Memon et al. 2011; Shanmuganathan \& Baskar 2015; Shaqour 2014; Singh 2011; Toh et al. 2012). Olympic-specific examples are:

- forgetting the space needed surrounding Olympic facilities (warm-up gyms, parklands, offices, etc.). E.g. for Atlanta 1996, the need for warm-up courses, extra parking and the demolition costs of the old Fulton Stadium were not calculated in (ACOG 1994), 
- poor planning and construction of venues (e.g. tennis courts faced the wrong direction (towards the sun) and had to be turned around, the swimming pool was notsuitable, so they constructed a new one,

- long decision-making processes and late realisation (e.g. delays in Athens (The Guardian 2003)),

- difficulties in finishing negotiations (partners speculate and use time pressure) or public procurements.

In the monitoring and control phase, one can observe poor site management, insufficient cost control, the complexity of the organisational structure, the lack of construction cost data, fraudulent behaviour and bribes causing cost increases (Abd-Karim et al. 2013; Abusafiya \& Suliman 2017, 35; Alfouzan 2013; Alinaitwe et al. 2013; Ameh et al. 2010; Bordat, McCullouch, Labi \& Sinha 2004; Le-Hoai et al. 2008; Doloi 2013; Mahamid \& Bruland 2011; Memon et al. 2011; Toh et al. 2012). Furthermore, insufficient and poor risk management can result in higher costs (Baldry 1998; Halloum \& Bajracharya 2012; Kwak \& Smith 2009; Patanakul 2014). An example is London 2012, which had problems with contractors handling the size of the project (e.g. the architect left, static problems, iconic venues were expensive to construct, size of the project; National Audit Office 2007a). Finally, further problems can occur in the communication. These factors are: poor coordination between the project participants and a lack of management knowledge (Alinaitwe et al. 2013; Halloum \& Bajracharya 2012; Shaqour 2014). Aspects of the lack of communication within the organisation, but also with external groups, were also identified in the case of the Olympic Games.

\section{Politically- and regulation-based cost overruns}

Further factors that have an influence on cost overruns can be found in politics and regulation. The political situation is crucial in order not to increase the costs. Therefore, non-supportive governmental policy, delays in decision-making by the government, lack of governmental control and regulations may support cost overruns (Ameh et al. 2010; Kasimu \& Abubakar 2012; Khodeir \& Hamdy 2015; Mahamid \& Bruland 2011; Morris 1990; Siemiatycki 2014; Shaqour 2014). These factors are supported by the theory of strategic misrepresentation. People systematically underestimate the costs and overestimate the resulting benefits (Flyvbjerg, Holm \& Buhl 2002, 2005; Wachs 1989), which relates to the "winner's curse", which we will explain later in detail. Examples of political and regulatory difficulties with the Olympic Games are:

- host city expectation of governmental or sponsor support, 
- missing governmental guarantees at bid stage may turn out not to be provided, e.g. in Seoul the government had withdrawn its financial support in 1987 but was persuaded to return to support the Games,

- political changes and new agenda-setting (e.g. changed decision-making competencies),

- avoidance of responsibility or difficulties in defining responsibilities and competencies,

- conflicts of interests regarding the Games investment and legacy plans,

- missing flexibility.

\section{Cost overruns based on project resources}

Project resources can be divided into material, labour and equipment. Regarding materials, the changes in the cost of building materials, the lack of construction materials in markets and material problems can lead to higher costs (Al-Jurf et al. 2010; Alfouzan 2013; Ameh et al. 2010; Bageis \& Furtune 2009; Kasimu \& Abubakar 2012; Khodeir \& Hamdy 2015; Insja \& Sihombing 2016; Mahamid \& Bruland 2011; Shanmuganathan \& Baskar 2015; Shaqour 2014; Singh 2011). For example, for Rio 2016 an oil crisis occurred during the preparation period of the Games (Osborn 2017), but also steel delivery crises have taken place. In addition to the material, labour can also lead to cost increases. This happens when workers are absent or unqualified or have no experience (Ali et al. 2017, 30; Kasimu \& Abubakar 2012; Khodeir \& Hamdy 2015; Mahamid \& Bruland 2011; Morris 1990). Labour problems have occurred in the Olympic Games preparations where there is poor timing and recruitment of skilled personnel (suboptimal contracting) and workers' strikes (e.g. in Sarajevo; Helbing 2015). For increased costs, the equipment may be responsible if the machines are too expensive or equipment is missing (Abd-Karim et al. 2013; Memon et al. 2011; Toh et al. 2012). So missing technical equipment from a stadium and other facilities might lead to higher costs.

\section{Environmentally-based cost overruns}

The last general category represents the environment, which is related to weather and location. On the one hand, unforeseen weather conditions may incur cost overruns; on the other hand, unsuitable climate conditions for working may be responsible (Doloi 2013; Singh 2011). For London 2012, for example, weather led to delays and brought timing under pressure. In concrete terms, this can be the need to clear snow or the construction ground being too wet or frozen (e.g. too-wet ground in London; Magnay 2012). In the end, poor field investigations, decisions for the wrong sites, land expropriation costs and relocation of inhabitants or busi- 
nesses are the reasons why the location leads to cost overruns. In addition, costs for a sustainable site may have an impact on the overall costs (Alinaitwe et al. 2013; Ameh et al. 2010; Morris, 1990).

\section{Event-specific-based cost overruns}

Some incidents that have occurred during the Olympic Games cannot be divided into the other categories. Therefore, the model was supplemented by the category event-specific factors. The event-related factors are:

- renovation of already existing stadiums - e.g. the roof of the Olympic Stadium in Barcelona was leaking even though it was newly built in 1989 (Botella 1995, 28),

- size of follow-up costs to transform competition sites into its final use (legacy transformation),

- effects of marketing campaigns to sell tickets or attract sponsors,

- cost effects caused by distance between the Olympic Village, the media village and sporting facilities (e.g. the lack of large plots of land in Athens 2004 (Richter 2012a) and Tokyo 1964 (Richter 2012b)),

- time pressure because of a fixed delivery date (e.g. for the FIS World Cup, architects described the lack of planning and the delays this caused; Strande 2009),

- contractors being late in obtaining more money for speedy construction (e.g. for Atlanta 1996, the construction company for the Olympic harbour in Savannah quit and a new company had to be found),

- changing or adding events by International Federations (IFs) (in terms of licensed equipment, etc.; e.g. new events in snowboarding, Alpine skiing, speed skating and curling in PyeongChang and new events in athletics, swimming and basketball in Tokyo 2020; CBC 2015; Homewood 2017),

- sudden unexpected need for an increased security level (e.g. Athens after 9/11 and the growing risks of terrorist attacks in Sochi; Sanburn 2012; Müller 2014, 634),

- illness (epidemic) (e.g. Zika virus in Rio; Zagorsky 2016),

- inappropriate speed of growth of the OCOG and its structures.

Flyvbjerg (2011) mentions the underestimation of risks due to complexity, and changing scope during the implementation period as the major reasons for cost overruns. Jackson (2002) supports this view by saying that the most serious problem in project management is planning a budget for future investments estimated with inadequate information. According to Jackson, it is necessary and important for good planning to define the scope and complexity of the project in a clear manner from the earliest stages. 
The 2012 FIS World Ski-Flying Championship in Vikersund, Norway, showed that a major reason for cost overruns was that, after the awarding of the event was made, priorities were often given to other things than constructing sports venues (see Solberg \& Preuss 2015).

Another trigger of costs turning out higher than planned is based on underestimated costs for the many capital investment promises that must be made during the bidding process. In the past, one could observe that the city that offered the "best" Games won and had to deliver. Cost underestimation would then lead to seriously higher costs than estimated, which is the so-called "winner's curse" (Andreff 2012). Massive cost overruns cause economic inefficiency. If investment decisions are based on underestimated costs, inputs may not be allocated to the most profitable projects. Major events are often supported financially by the public sector, and if politicians are guided wrongly by incorrect cost budgets, they may support events that they would otherwise have rejected if the information had been correct. We come back to this theoretical perspective in our results section.

Another factor of cost overruns has its roots in changing the overall project scope by adding detailed investment projects that are not really necessary for the Olympic Games, though host city politicians like to use the Olympic Games as an argument to get them financed. These constructions are not required by the IOC, e.g. the renovation of a post office, new hospital or theatre, a programme to renovate the historical or architectural patrimony. Additionally, often those who support the construction of infrastructure and sport venues are free riders who do not share in funding the venues, but benefit from them (see Solberg \& Preuss 2015). Often a major reason why massive cost overruns occur are extensions of the objectives after the events have been awarded. This applied to both the FIFA World Cup 2010 in South Africa and the World Skiing Championship 2012 in Norway, for which a number of stakeholders entered the scene after the events were awarded, with other objectives than just building sports venues. We come back to this theoretical perspective in our results section.

Finally the PRINCIPAL-AGENT theory helps explain cost overruns at mega sporting events that are awarded through bidding. The AGENT (the city) has quite realistic knowledge of the overall costs. However, due to information asymmetry towards the public (PRINCIPAL, as they are taxpayers) and the need for the public to support the bid, the city (AGENT) announces lower costs than expected. Right after being awarded the Games, much higher costs are announced, as happened for London 2012, for example. Preuss \& Schnitzer (2012) explain a similar situation for the FIFA World Cup. We come back to this theoretical perspective in our results section. 


\subsection{Comparative Issues}

In this study we also intended to compare cost overruns at the Olympic Games with those observed for other public projects. However, looking into the literature we have two concerns in doing this comparison:

1. Cost overruns differ for different projects. This means that cost overruns for road construction cannot be compared with cost overruns for housing projects.

To provide evidence, we looked for studies that investigated cost overruns in different branches, but in the same cultural area. Singh $(2010,45)$ shows that cost overruns are different in various project types in India. In total, India has an average rate of cost overruns of $15.2 \%$, but there are some areas where costs appear to be smaller than first estimated (e.g. coal, mines and telecommunication). By contrast, there are areas in which costs increase even faster than the country's average (e.g. finance, health and family welfare).

Table 3 Cost overruns in infrastructure projects (April 1992 - March 2009 in India)

\begin{tabular}{lcrrr}
\hline Sector & $\begin{array}{c}\text { Number } \\
\text { of }\end{array}$ & Mean & \% Cost Overun \\
\cline { 4 - 5 } & Projects & & & $\begin{array}{c}\text { \% of Projects } \\
\text { with Positive } \\
\text { Cost Overrun }\end{array}$ \\
\hline Atomic energy & 12 & 15.05 & 113.12 & 25.00 \\
Civil aviation & 47 & -2.27 & 40.52 & 42.55 \\
Coal & 95 & -19.90 & 73.85 & 22.11 \\
Fertilisers & 16 & -12.57 & 28.92 & 25.00 \\
Finance & 1 & 132.91 & 0 & 100.00 \\
Health and family welfare & 2 & 302.30 & 92.96 & 100.00 \\
I \& B & 7 & 14.00 & 62.97 & 42.86 \\
Mines & 5 & -33.16 & 20.65 & 0.00 \\
Petrochemicals & 3 & -12.22 & 25.92 & 33.33 \\
Petroleum & 123 & -16.10 & 28.96 & 20.33 \\
Power & 107 & 51.94 & 272.50 & 46.73 \\
Railways & 122 & 94.84 & 178.86 & 82.79 \\
Road transport and highways & 157 & 15.84 & 62.46 & 54.14 \\
Shipping and ports & 61 & -1.35 & 84.35 & 31.15 \\
Steel & 43 & -15.88 & 47.78 & 18.60 \\
Telecommunication & 69 & -32.09 & 57.59 & 15.94 \\
Urban Development & 24 & 12.31 & 50.27 & 41.67 \\
\hline Total & 894 & 15.17 & 132.27 & 40.72 \\
\hline
\end{tabular}

Source: Singh $(2010,45)$ 
The comparison of studies about cost overruns in public sector projects shows differences in the amount and occurrence of cost overruns regarding the same kind of projects. There are also differences in the significance of the various factors worldwide when it comes to developing countries (Abdel-Hafeez et al. 2016; Aftab, Ismail, Noor \& Ahmad 2014; Aibiniu \& Jagbonon 2002; Flyvbjerg 2009; Inuwa, Saiva \& Alkizim 2014; Singh 2010). Comparing studies that analysed cost developments of investment projects in different countries makes it clear that country-specific differences exist.

2. Cost overruns differ for different countries. This means that the same construction projects cause different cost overruns in different countries.

To find evidence, we now need to focus on studies that investigated the same industry but in different nations. Comparing cost overruns of railway projects in different countries, big differences are noticeable. The highest cost overruns of approximately 95\% are witnessed in India (Singh 2010). Whereas the smallest cost increase points at the Netherlands with only $10.6 \%$ (Cantarelli, Flyvbjerg \& Buhl 2012). Flyvbjerg et al. (2002) compared cost overruns in Europe with those in the U.S. and other geographical areas, and came up with the conclusion that there are differences between other geographical areas (64.4\%) and Europe as well as the U.S. Even considering only one country, there are some differences in terms of cost escalations (Flyvbjerg et al. 2002; Love, Ahiaga-Dagbui, Welde \& Odeck 2017; Pickrell 1990).

Table 4 Cost overruns in rail projects in different countries

\begin{tabular}{lcl}
\hline Country & Cost Overrun (\%) & Source \\
\hline Australia & 23.00 & Love, Zhou, Edwards, Irani \& Sing 2017 \\
India & 94.84 & Singh 2010 \\
Netherlands & 10.60 & Cantarelli, Flyvbjerg \& Buhl 2012 \\
Sweden & 17.00 & Riksrevisionsverket 1994 \\
South Korea & 48.00 & Lee 2008 \\
United States & 50.00 & Pickrell 1990 \\
& 42.00 & Love, Ahiaga-Dagbui, Welde \& Odeck 2017 \\
& 40.80 & Flyvbjerg, Holm \& Buhl 2002 \\
Europe & 34.00 & Flyvbjerg, Holm \& Buhl 2002 \\
20 countries on & 44.70 & Flyvbjerg, Holm \& Buhl 2002 \\
$\mathbf{5}$ continents & & \\
\hline
\end{tabular}


The Olympic Games are a mega project with very different investment structures. It includes transport infrastructure, IT infrastructure, housing infrastructure, fairground construction, park construction, sport venue construction and in a way some iconic architecture.

Additionally, the Olympic Games are moving from country to country and cultural area to cultural area. This means that there are various options for calculating the costs, the intensity of corruption in a country, and changes in political interests that use the Olympic Games as an engine for triggering side effects. Therefore, it seems that there are no solid scientific grounds for research comparing the Olympic Games with any other mega project in the same country and with any similar mega sporting project from a different country.

In general, the challenge in project management is to minimise the risks of cost overruns and thus keep the project on budget (Abusafiya \& Suliman 2017). Nevertheless, it proves to be difficult and only with a good reason scientifically possible to compare infrastructure projects with the Olympic Games, because there are not only construction projects, but rather a complex project with a variety of project management mechanisms in construction and organisation. This fact was proven by the comparison made by Baloyi and Bekker (2011), who focused on categorising the causes of cost overruns, in an analysis framework developed by Odeh and Battaineh (2002) for general projects. In the case of stadiums at the FIFA World Cup 2010 in South Africa, they concluded that there were significant differences between those factors that trigger cost overruns for general projects and those for the construction of stadiums in South Africa for the FIFA World Cup 2010.

\subsection{Olympic Games and Mega Sports Events}

When looking at the Olympic Games, there are different kinds of costs and revenues. Generally, the budget is divided into organisational and infrastructural costs/ revenues. The organisational budget is included in the budget of the Organising Committee of the Olympic Games (OCOG). It is also split into a revenue and a cost side. The main revenues an OCOG can generate are the IOC contribution from selling television rights, revenues from TOP sponsorship, local sponsorship and official suppliers, the revenues from ticket sales and merchandise, and subsidies from the government, if applicable. On the expenditure side of the OCOG budget are capital investments for transforming sports facilities and the operational costs for staging the Olympic Games, such as rental costs, Games workforce, technology and telecommunications, ceremonies, catering, transport, security and adminis- 
trative costs. The OCOG budget is mainly financed by private funds. In addition to the OCOG budget there is a so-called non-OCOG budget that is mostly financed by the city, regional or state authorities, but also by the private sector. These investments are capital investments and include the building and renovation of the airport, roads, accommodation, sports venues, and Olympic and media villages (IOC 2010) ${ }^{6}$. Cost underestimation in the budget usually is about investment cost in general infrastructure and Olympic sporting infrastructure. In a very small number of cases, these underestimates occur in the organisation costs (Andreff 2016).

Usually the Olympic Games are expensive if the host city plans intensive investment in traffic infrastructure, communication systems, housing and sports facility construction (e.g. Sydney 2000, Barcelona 1992, Seoul 1988, Montreal 1976 and Munich 1972). If costs are mainly based on organising and staging the Games, they will be modest (e.g. Atlanta 1996 and Los Angeles 1982) (Preuss 2006). Nevertheless, mega sporting events are often used to leverage urban development, renovation or refurbishing (Preuss 2004). If infrastructural projects happen to be delayed and cannot stick to the time schedule, they usually generate cost overruns (Andreff 2016).

6 In recent times, airports and transport infrastructure are no longer listed in the Olympic Games Candidature File. 
Open Access This chapter is licensed under the terms of the Creative Commons Attribution 4.0 International License (http://creativecommons.org/licenses/by/4.0/), which permits use, sharing, adaptation, distribution and reproduction in any medium or format, as long as you give appropriate credit to the original author(s) and the source, provide a link to the Creative Commons licence and indicate if changes were made.

The images or other third party material in this chapter are included in the chapter's Creative Commons licence, unless indicated otherwise in a credit line to the material. If material is not included in the chapter's Creative Commons licence and your intended use is not permitted by statutory regulation or exceeds the permitted use, you will need to obtain permission directly from the copyright holder.

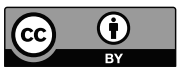




\section{Methodology}

It is not easy to collect financial data for a complex event such as the Olympic Games. During our research it very soon became clear that often the financial data of capital investments disappeared or were hidden or in ever-changing mixed categories. Furthermore, we learnt during our research that the reliable collection of all data regarding the Olympic Games is not possible for the following reasons:

1. Capital investments are not made by one authority and are not all displayed in a regular reporting system.

2. Capital investments are often a Public Private Partnership (PPP) and the private part is not published.

3. Costs and revenues are accounted differently.

4. The Olympic Games and Olympic Winter Games are different with regard to capital investments.

5. Information is not always clear about the particular time for which the amount displayed was projected.

As we explained above, we define a cost overrun $\mathrm{COV}$ if the OCOG budget or some non-OCOG budget does not succeed in collecting more revenues than expected ex-ante:

$$
\mathrm{COV}=R_{t}-R_{t-n}
$$

(C) The Author(s) 2019

$\mathrm{H}$. Preuß et al., Cost and Revenue Overruns of the Olympic

Games 2000-2018, Event- und Impaktforschung, 
In Flyvbjerg's (2011) view, a comparison of bid budget to final budget is valid. Like Flyvbjerg et al. (2016), we use the first serious projection (displayed in the candidature files), as that is the promise to the population, and compare it to the last budget, which covers the final revenues, expenditures and capital costs.

However, we follow a different method than Flyvbjerg et al. (2016) because, when we consider only cost overruns by looking at costs from bid book files and compare them to the final costs (wherever they can be found), we will not picture the reality for the following reasons:

1. OCOG budget: If we compare only OCOG expenditures with final OCOG expenditures we forget to consider the final OCOG revenues, which are also in fact often higher than final expenditures and result in a balanced or even surplus budget. A cost calculation should be connected to a revenue calculation.

2. Non-OCOG budget: If we take a very first bid concept (master plan) we tap into the politically desired cost underestimation, which was tactically relevant to position the city better in the bid race. Then we have to decide if a study like this would measure the actual cost overrun of the project or the cost overruns that arise due to bidding tactics.

3. Non-OCOG budget: If we take the official bid concept (from the candidature file), we have an acceptable starting point, as that is the budget promised to the public. However, we still have the concern (see point 2). The other problem is to find reliable bid data for all venues and the final budget that is really based on capital costs of the Olympic project. Our concern is that many non-Olympic infrastructural developments become connected to the Games and appear in some statements about final costs (often in media articles). If we take cost statements that have many non-Olympic related capital investments included, we are no longer talking about cost overruns. If we do that, we try to compare a totally different scope of projects. The problem here is that Olympic Games are not one infrastructure project but many. The reality is that there is often no final cost displayed for all the venues and infrastructural changes in official documents.

Overall the research design for this study will adopt the following delineation:

1. We evaluate the OCOG costs and revenues over a period of eight years (from the candidature file to the final cost statement).

2. We acknowledge the recurrent changes in the Olympic Games project and its so-called gigantism. Therefore, the research is limited to the past five Olympic Games (Sydney 2000 to Rio 2016) and past five Olympic Winter Games (Salt Lake City 2002 to PyeongChang 2018). 
3. We divide the cost/revenue overruns into three budgets, the OCOG costs, the OCOG revenues and a set of directly Olympic-related non-OCOG costs.

4. The non-OCOG costs are selected to create a "basket" of different infrastructural projects, such as an Olympic Stadium, a multipurpose hall, an Olympic Village and the International Broadcasting Centre (IBC) and Main Press Centre (MPC). This basket provides a good mixture of key infrastructure projects needed for all Games editions, representative of the type (competition venue/housing), the size and the complexity of most of the venue-related infrastructure projects.

It became clear that the OCOG budget can consist of up to 300 accounting positions and the revenues of 100. Due to the different display of costs from Games to Games, we decided to categorise them. These categories are then comparable from Games to Games and provide information about the cost/revenue overruns.

\subsection{Availability of Financial Data from the Olympic Games}

The gathering of reliable financial data about the costs and revenues of the Olympic Games is extremely difficult. Data published in media reports are often estimates or relying on wrong information or wrong data. The wrong information are given from those that want to spread the message that the event is cheap respectively expensive.

The following figure illustrates the public display of costs in billions of euros regarding the world exposition (EXPO) in Milan in 2015. The announced costs vary from EUR 1 billion to 18 billion. Furthermore, the figures show that different costs were taken into account from one estimate to the other. Similar findings were found for the Olympic Games. 


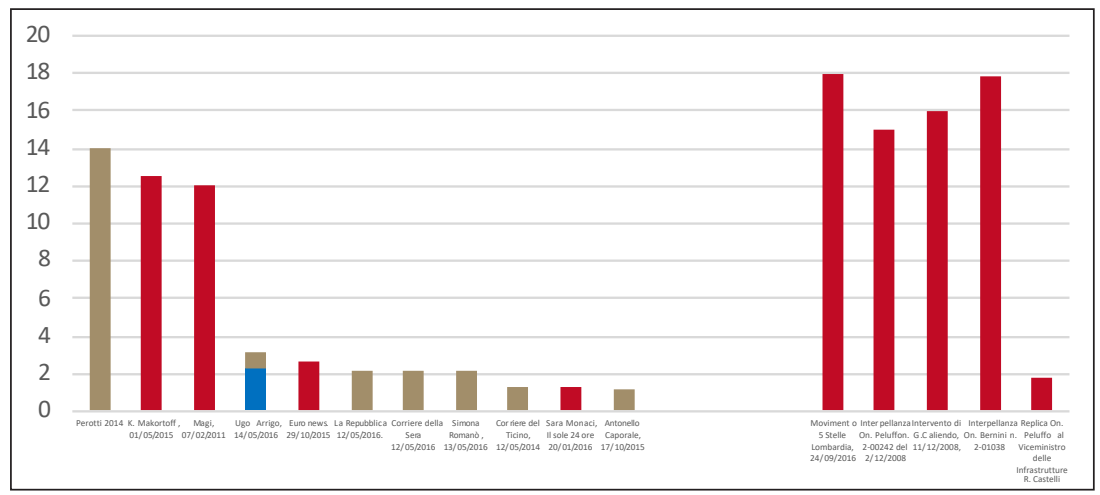

Legend: brown $=$ total costs $/$ red $=$ investments $/$ blue $=$ operation costs

Fig. 7 Costs EXPO 2015 in billions of euros announced by different media Source: Massiani (2018)

Data collection for this study was organised manifold to use the highest possible variety of information sources from which we gathered the figures. This is important for several reasons:

1. To make sure we obtain at least some data.

2. If available, to crosscheck the data and avoid using wrong information that may have been copied from a particular political party or any kind of vested interests.

3. To avoid being dependent on one single source of information.

The next figure visualises data collection implemented for this study. It shows the chronology followed to access the data.

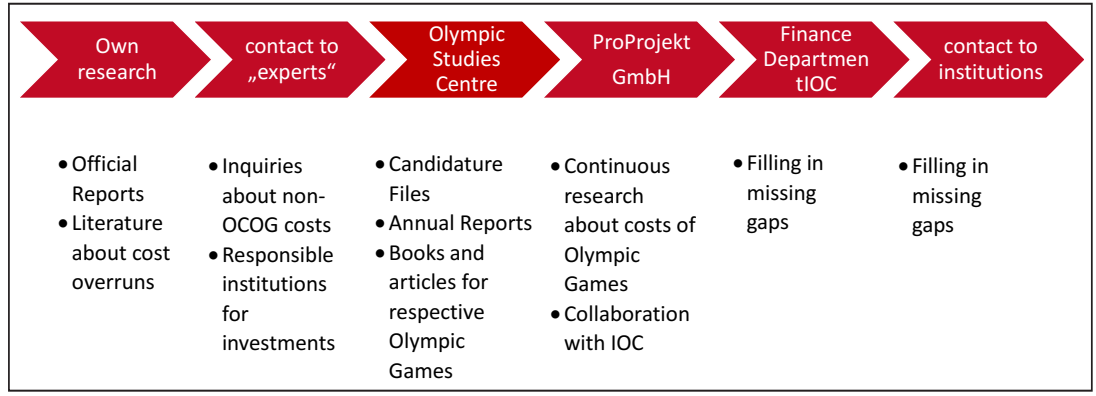

Fig. 8 Chronology of data collection 
First we started with literature research and used our own private Olympic data collection as we do Olympic research for more than 25 years. Then we contacted several experts (Olympic scholars). The following table shows all experts who were contacted as well as their function and the data they could provide.

Table 5 Experts contacted to gather data

\begin{tabular}{|c|c|c|c|}
\hline & Name & Function & Useful Data \\
\hline \multirow[b]{2}{*}{ 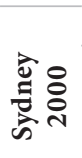 } & Rizakos, Angie & Assistant Manager, SOCOG & Non relevant data \\
\hline & Taylor, Tracy & $\begin{array}{l}\text { Professor, University of Tech- } \\
\text { nology } \\
\text { Sydney }\end{array}$ & Non relevant data \\
\hline \multirow{2}{*}{ 氶 } & Bullock, Fraser & $\begin{array}{l}\text { COO Salt Lake Organising Com- } \\
\text { mittee } 2002\end{array}$ & Useful data \\
\hline & Fay, Ted & Professor, SUNY Cortland & Useful data \\
\hline \multirow{4}{*}{ 冚 } & Cartalis, Kostas & $\begin{array}{l}\text { Professor, University of Athens / } \\
\text { formerly Minister of Culture in } \\
\text { charge of Athens } 2004\end{array}$ & Useful data \\
\hline & Gargalianos, Dimitrios & $\begin{array}{l}\text { Professor, Democritus Universi- } \\
\text { ty of Thrace }\end{array}$ & Non relevant data \\
\hline & Georgiadis, Kostas & $\begin{array}{l}\text { Professor, University of Pelopon- } \\
\text { nese }\end{array}$ & Non relevant data \\
\hline & Panagiotopoulou, Roy & Professor, University of Athens & Useful data \\
\hline \multirow{5}{*}{ 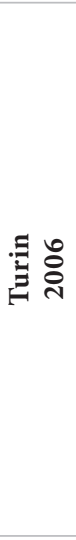 } & Bondonio, Piervincenzo & $\begin{array}{l}\text { Past-president, OMERO, Inter- } \\
\text { departmental Research Centre } \\
\text { on Urban and Events Studies, } \\
\text { University of Turin }\end{array}$ & Useful data \\
\hline & Bottero, Marta & $\begin{array}{l}\text { Associate Professor in Project } \\
\text { Appraisal and Planning Evalua- } \\
\text { tion, Politecnico di Torino }\end{array}$ & Useful data \\
\hline & Castellani, Valentino & $\begin{array}{l}\text { Former Mayor of Turin (in 2006) } \\
\text { Professor at the University of } \\
\text { Turin }\end{array}$ & Non relevant data \\
\hline & Guala, Chito & $\begin{array}{l}\text { OMERO Group - sociology } \\
\text { professor }\end{array}$ & Non relevant data \\
\hline & Solberg, Arne & $\begin{array}{l}\text { Professor, Trondheim Business } \\
\text { School }\end{array}$ & $\begin{array}{l}\text { Non relevant data } \\
\text { but several journal } \\
\text { papers }\end{array}$ \\
\hline \multirow{2}{*}{ 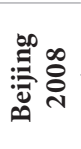 } & Hu, Xiaoqian Richard & $\begin{array}{l}\text { Professor, Xinhua University } \\
\text { Beijing }\end{array}$ & Non relevant data \\
\hline & Lin, Xinpeng & $\begin{array}{l}\text { Professor, Beijing Sport Univer- } \\
\text { sity }\end{array}$ & Non relevant data \\
\hline
\end{tabular}




\begin{tabular}{|c|c|c|c|}
\hline & Name & Function & Useful Data \\
\hline 离 & Parent, Milena & Professor, University of Ottawa & Useful data \\
\hline \multirow{2}{*}{ 泀 } & Girginov, Vassil & $\begin{array}{l}\text { President European Association } \\
\text { for Sport Management }\end{array}$ & Non relevant data \\
\hline & Rizakos, Angie & $\begin{array}{l}\text { Olympic Delivery Authority } \\
\text { (ODA) }\end{array}$ & Non relevant data \\
\hline \multirow{6}{*}{ ॠี } & Aivazyan, Sima & $\begin{array}{l}\text { Head or PR Department, Olymp- } \\
\text { stroy }\end{array}$ & Non relevant data \\
\hline & Belousov, Lev & $\begin{array}{l}\text { Rector of Russian International } \\
\text { Olympic University (RIOU) }\end{array}$ & Non relevant data \\
\hline & Bocharnikova, Evgeniia & Media Relations, Sochi OCOG & Non relevant data \\
\hline & Dobis, Michael & $\begin{array}{l}\text { Head of Unit Science and } \\
\text { Research, German Embassy } \\
\text { Moscow }\end{array}$ & Non relevant data \\
\hline & Macharadze, Iya & $\begin{array}{l}\text { Head of the whole Master's, } \\
\text { RIOU }\end{array}$ & Non relevant data \\
\hline & Peshin, Nikolay & $\begin{array}{l}\text { Vice-Rector for research at RIOU } \\
\text { Sochi OCOG }\end{array}$ & Non relevant data \\
\hline \multirow{2}{*}{$\stackrel{0}{\stackrel{0}{\approx}}$} & Braga, Tania & $\begin{array}{l}\text { Head of Sustainability, Accessi- } \\
\text { bility and Legacy, Rio OCOG }\end{array}$ & Useful data \\
\hline & Payne, Michael & Consultant, Rio Candidate City & Non relevant data \\
\hline 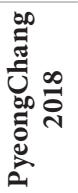 & Hong, Seok-Pyo & $\begin{array}{l}\text { Professor, Kangwon National } \\
\text { University, Chuncheon, OSC }\end{array}$ & Useful data \\
\hline
\end{tabular}

Experts from former host cities were contacted to gather data that may be hidden in local archives.

The next step was to visit the IOC Olympic Studies Centre (OSC) in Lausanne and the National Olympic Academy in Frankfurt in order to access a huge collection of sources about the Olympic Games. The IOC OSC and Finance Department supported this research intensively and provided us with access to public and non-public archives for OCOG and non-OCOG budgets.

The ProProjekt $\mathrm{GmbH}$ agency, which was managing several candidate cities, including the two German bids (Munich 2018 and Hamburg 2024), supported our research. They provided us with their database on the OCOG and non-OCOG 
budgets of several previous Games. These data were extremely useful and were in particular used to crosscheck the data we had collected before.

The final step was to contact the ministries and official departments in host cities, requesting data about the non-OCOG budgets. However, most of them could not or did not want to provide data. It proved to be difficult receiving useful data on non-OCOG budgets.

\subsection{Preparation of Data}

The preparation of data started with a differentiation of data required. We wanted to avoid mixing categories or considering data that are not related to the Olympic Games. In this study we distinguish between:

1. OCOG revenues $=$ revenues the $\mathrm{OCOG}$ receives, including the $\mathrm{IOC}$ contribution.

2. $\mathrm{OCOG}$ costs $=$ all operational expenditures of the OCOG, including royalties paid to the IOC.

3. Non-OCOG costs = investments in a selection of key infrastructure projects needed for hosting the Games, as described in the "Methodology" section.

Available data about Olympic Games costs and revenues in the sources are neither homogeneous by currency nor by date. For example, in older candidature files (until the 2012 candidature process) the budgets are in USD at the time of writing the candidature file. This makes at least eight years before the Olympic Games were staged and still many years before the investments were made. Until the 2012 candidature process, these figures did not take inflation into account and if they did, they must have taken the right inflation rate. Estimating the rate of inflation can also be seen as a source of error.

The bid process has changed significantly over time. Since $2006^{7}$, the IOC has requested in candidature files that the budget must be provided in both USD and the local currency. Thus Rio 2016 were the first Games to stick to this new procedure and consequently provide transparent data about the exchange rates

7 The Candidature File for Sochi 2014 mentioned only that the existing tables with local currency and inflation adjusted figures were in the annexes of the document. These were not accessible to us. It was only since the Candidature Process for the Olympic Games 2016 that the tables in the candidature file had to include national currency and inflation adjusted figures. 
used. Additionally, the IOC expects the budget to be displayed in two tables, one with current values and one with inflation-adjusted values. In the present study, for the eight Olympic Games investigated before Rio 2016, the values had to be adjusted for inflation. However, even the data provided for Rio 2016 and PyeongChang 2018 needed to be re-adjusted because the budgets projected were based on inflation rates estimated at the time of bidding; at this time, the candidature committees did not know the real inflation rates and construction price index of the future. Tab. 6 shows the revenue of the Rio 2016 and PyeongChang 2018 OCOGs and compares the real inflation with the estimated inflation by the bid committee. Thus, Rio 2016 underestimated the inflation rate, which led to $27 \%$ lower costs than were finally incurred, while PyeongChang 2018 overestimated the inflation rate and had at the end $12 \%$ less costs. This shows the power of inflation on perceived cost overruns. However, it will remain tricky if not impossible to estimate the true inflation rate, but bid committees should put more effort into using realistic rates.

Table 6 Comparison of estimated and real inflation of the total OCOG revenues

\begin{tabular}{lllll}
\hline & Estimated Inflation & Real Inflation & Difference & $\%$ \\
\hline Rio 2016 & $7,557,992,000 \mathrm{BRL}$ & $10,380,766,000 \mathrm{BRL}$ & $2,822,774,000 \mathrm{BRL}$ & $27 \%$ \\
\hline $\begin{array}{l}\text { Pyeong- } \\
\text { Chang }\end{array}$ & $2,195,923,000,000 \mathrm{KRW}$ & $1,968,582,765,000 \mathrm{KRW}$ & $-227,340,235,000 \mathrm{KRW}$ & $-12 \%$ \\
2018 & & & & \\
\hline
\end{tabular}

Reports that contain data for post-bidding years though these data pertain to earlier years than when the final costs and revenues are known and usually publish figures in local currency. Revenues and costs in the bid documents before Rio 2016 were usually in USD. To minimise conversion errors, we decided to convert the OCOG budget from the candidature file into local currency by using the current exchange rate at that time. After converting all available data into one currency, the host country's GDP deflator for the respective years was used to adjust revenues and costs to one base year. Thus a comparison of the data from the candidature file with data published during the preparation period and data available on the final revenues and costs has been made possible. 
For the OCOG budget, we opted to take an overall inflation rate (the GDP deflator), while for investments in infrastructure, we opted for construction price indices. In countries where we could not find a construction price index, we used the GDP deflator of the respective country. Missing inflation inevitably translates into an overestimation of perceived cost overruns which do not exist in reality. For example, investment in a stadium with a relatively normal construction price index of $4 \%$ p.a. over six years (from bidding to construction two years prior to the Games) results in a $25 \%$ cost increase simply due to inflation. Therefore, any study that ignored inflation rates would wrongly exhibit higher costs than the actual costs. On the other hand, the IOC contribution (revenue) that is paid only in instalments over time, with a large portion in the Games year, needs to be deflated. If revenues were not discounted at the bidding time, they would be announced with a too-optimistic value.

In this study we will only show the percentage changes compared to the initial budget, because the intention is not to show which Olympic Games have been the most costly or the cheapest. Nonetheless, the percentages are based on real cost figures. Using the percentage changes enables us to show and interpret a "five-Games" average of costs and revenue overruns in total and by category. This provides some insights into the areas where costs and revenue overruns emerge the most often.

There are some cases where, at the time of bidding, there was no information on certain categories of OCOG and non-OCOG revenues and expenditure. When the category was first mentioned, we took that value as the starting value. When it was in the final budget only, a cost overrun of $0 \%$ occurred. However, even though that happened often, we then took the real value of that cost into our cost overrun calculation as that was always done based on real figures. In other words, the final costs of the unlisted category were taken into the total final costs, but they were based on zero in the bid stage (as it was not mentioned there), and therefore huge nominal cost overruns occurred. Thus, even if some categories are displayed only with $0 \%$ cost overruns in the final budget, the overall percentage figure reflects the cost overrun that occurred at the end. 


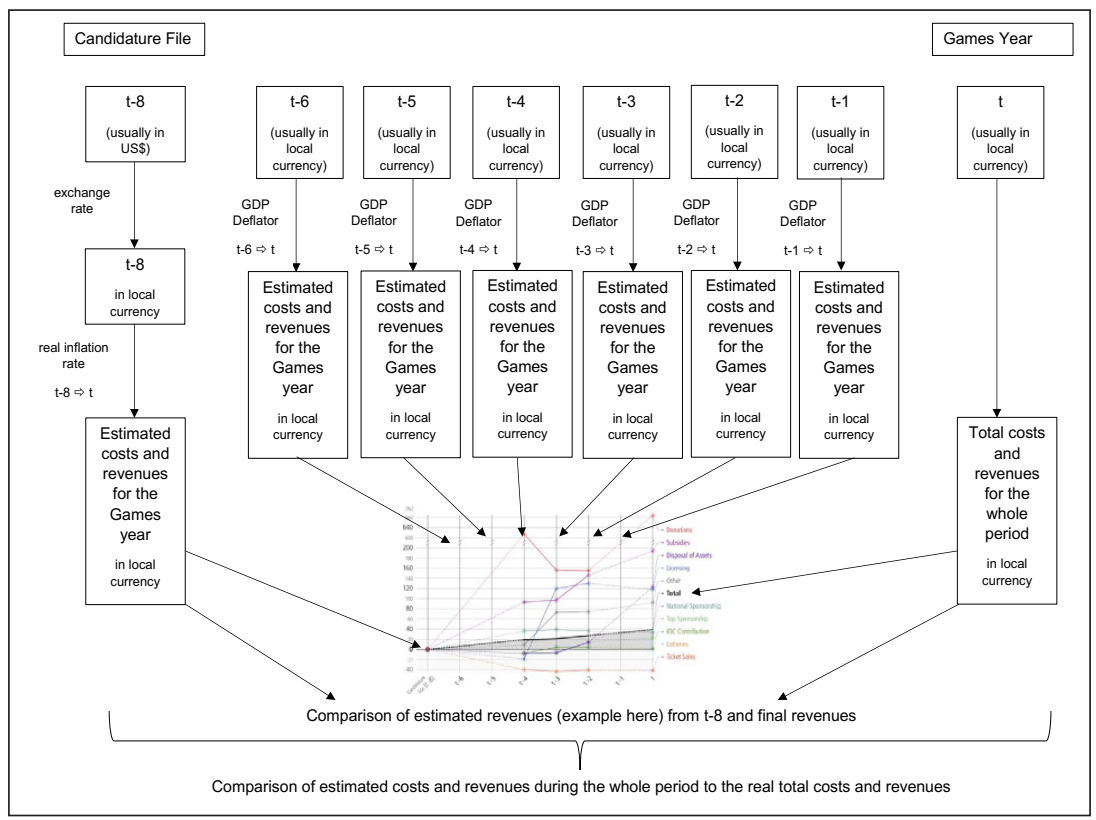

Fig. 9 Methodology of data conversion

It is difficult to obtain information about non-OCOG costs. Non-OCOG costs include all capital investments that need to be delivered for the Olympic Games. It is highly debatable which of the capital investments are really needed and which are added simply because the Olympic Games open up an opportunity and provide good arguments for incorporating into the Games event some investment projects that were planned regardless of the Games.

The Olympic Games are a complex event with more than 300 projects to be coordinated, involving several administrative levels of a country. The resources to finance the new or to refurbish the old infrastructure come from many different authorities and often even from different communities, private investors or state authorities. This complex situation makes it impossible to collect a comprehensive set of infrastructure costs. Often even a single project (e.g. Olympic Stadium) attracts financing from different entities (e.g. the state pays for ground work, accessibility; the city for the construction, a private investor for the VIP areas). The non-OCOG budget here includes all capital investments that are needed for staging the Olympic Games, but does not encompass general infrastructure improvements such 
as road, metro or railway construction, new harbours and airports or a general re-urbanisation of cities by planting trees, creating beaches, building museums or pedestrian zones and public recreation areas. Given that different stakeholders are in charge of the different venues for the Olympic Games, we decided to compose a subset of exemplary venues (see table below) and look at the cost overruns for their construction. We avoided a selection bias by taking a variety of very different venues and not looking at who was investing.

Our investment sample (hereinafter referred to as "basket") represents a fair mix of venues that are definitely needed for staging the Olympic Games. The rationale behind this procedure is that a good bundle (basket) of investment projects, such as an Olympic Village or an Olympic Stadium, triggers many possible cost overruns that can be expected for the Olympic Games. In other words, cost overruns of the well selected exemplary investments will show relatively the same cost overruns that a larger or a full sample of all Olympic investments would create. This is the reason why we display all the results only in percentages, as the nominal costs would represent only the basket and not the entire costs of the Games.

The rationale behind the method to work with a representative "basket" was taken from economics and enables us to:

a. Manage the problem of lacking financial information about all capital investments in the Olympic Games;

b. Avoid misinterpretation regarding the fact that the Olympic Games are not one single mega project, but a bundle featuring a high number of separate (mega) projects. It is to be expected that several projects get added and change over the eight years of preparations (so-called changes to the master plan). However, even though one can argue we should label these costs as overruns, it only shows a small part of them, namely those based on project changes. Here the "basket" of investments contains the same projects over the entire period and therefore displays the cost overruns in a comparative way;

c. The basket contents venues that are financed considerably by public money (see next table). Projects financed by public money cause higher cost overruns than private investments (see discussion below and chapter discussion and rationale on the PRINCIPAL-AGENT theory). With public finance there is always an incentive to spend without counting (since it is not your own but public money), to bargain additional subsidies and the like.

The venues picked for research into the Olympic Winter Games and Olympic Games are listed below. All of them are large venues and address different industries such as housing, technology, special architecture (iconic buildings), special construction (ski 
jump, velodrome), etc. Furthermore, this basket represents the most iconic venues of the Games, which are often the most expensive ones and consequently one can expect the highest cost overruns. Thus, the data of our basket may lead rather to an overestimation of the cost overruns than being too low (conservative approach).

Table 7 Definition of "baskets" for the non-OCOG budget

\begin{tabular}{ll}
\hline $\begin{array}{l}\text { Basket of venues for the } \\
\text { Olympic Winter Games }\end{array}$ & $\begin{array}{l}\text { Basket of venues for the } \\
\text { Olympic Games }\end{array}$ \\
\hline Olympic Stadium & Olympic Stadium \\
\hline Ski Jumping Hill & Swimming Pool \\
\hline Sliding Centre & Multipurpose Hall \\
\hline Ice Stadium & Velodrome \\
\hline Olympic Village & Olympic Village \\
\hline IBC/MPC & IBC/MPC \\
\hline
\end{tabular}

For the former Olympic cities of Sydney and London, we looked only at the costs of the public sector, as the figures we had were only those from public money. For Sydney 2000, therefore, we considered in the Candidature File only the proportion of public money. In the case of London 2012, the Candidature File stated that all Olympic-related costs would be paid by the government. Due to changes in the master plan, the costs severely increased, and some parts of the venues were covered by private funds. Nevertheless, for our calculation, we took at the beginning (candidature file) and at the end (final report) only the amount of public money. The total nominal costs of London 2012 that were available to us were largely found in newspapers and therefore did not seem reliable to us. In the cases of Athens 2004 and Rio 2016, we took the total costs, although almost all venues were completely financed by public money. The exact percentage of the public costs of the individual venues of the Olympic Games is entered in the following table. 
Table 8 Percentage of public costs of the total costs of Olympic Games venues

\begin{tabular}{lccccc}
\hline & Sydney & Athens & Beijing & London & Rio $^{* * *}$ \\
\hline Olympic Stadium & $19 \%$ & $100 \%$ & N/A & $88 \%$ & $100 \%$ \\
\hline Swimming Pool & N/A & $100 \%$ & N/A & $93 \%$ & $100 \%$ \\
\hline Multipurpose Hall & $72 \%$ & $100 \%$ & N/A & $100 \%$ & $32 \%^{* *}$ \\
\hline Velodrome & $100 \%$ & $100 \%$ & N/A & $94-98 \%^{*}$ & $100 \%$ \\
\hline Olympic Village & N/A & $\begin{array}{c}\text { Non-residential con- } \\
\text { structions implemented } \\
\text { with public funds }\end{array}$ & N/A & $80 \%$ & $0 \%$ \\
IBC/MPC & N/A & $100 \%$ & N/A & $99 \%$ & $32 \% \%^{* *}$ \\
\hline
\end{tabular}

* range of percentages due to different sources

** Multipurpose Hall Carioca Arena and IBC/MPC are listed together because the report has summarised it, as it is located at the same area

*** Official final costs are not available as the Games had not been formally wound up at the time of writing.

Sources: ATHOC (n. d.); Camara dos Deputados (2017); Department for Culture, Media and Sport (2012b); Detail (2012); Gibson (2011); Kim (2011); Panagiotopoulou (2014); SOCOG (2001); StadiumDB (n. d.); The Guardian (n. d.)

For Salt Lake City 2002, it seems that some of the venues were totally financed by private sources (see chapter on Salt Lake 2002), whereas the Olympic Village and IBC/MPC were totally financed by public money. The venues of the other host cities of the Olympic Winter Games were almost exclusively financed by public funds. The exception is the Olympic Village for PyeongChang 2018, which was totally financed by private investors. Tab. 9 shows the exact breakdown.

Table 9 Percentage of public costs of the total costs of Olympic Winter Games venues

\begin{tabular}{lccccc}
\hline & $\begin{array}{c}\text { Salt Lake } \\
\text { City }\end{array}$ & Turin & Vancouver & Sochi & $\begin{array}{c}\text { Pyeong- } \\
\text { Chang }\end{array}$ \\
\hline Olympic Stadium & $75 \%$ & N/A & $100 \%$ & $100 \%$ & $100 \%^{* * *}$ \\
\hline Ski Jumping Hill & $0 \%$ & $100 \%$ & $100 \%$ & $100 \%^{* *}$ & $100 \%^{* * *}$ \\
\hline Sliding Centre & $0 \%$ & $100 \%$ & $100 \%$ & $100 \%$ & $100 \%^{* * *}$ \\
\hline Ice Stadium & $33 \%$ & $100 \%$ & $100 \%$ & $100 \%$ & $100 \%^{* * *}$ \\
\hline Olympic Village & $100 \%$ & $100 \%$ & $100 \%^{*}$ & $100 \%^{* *}$ & $0 \%$ \\
\hline IBC/MPC & $100 \%$ & $100 \%$ & N/A & N/A & N/A \\
\hline
\end{tabular}

$\star 9 \%$ were funded by governmental contributions; $91 \%$ were funded by municipal contributions

${ }^{* *}$ funded by State-secured loan

$* * * 75 \%$ were funded by central government and $25 \%$ by local government

$* * * *$ Official final costs are not available as the Games had not been formally wound up at the time of writing.

Sources: Bottero, Sacerdotti \& Mauro (2012); Hong (2017); Müller (2014); SLOC (2001); VANOC (2010b) 
Due to the presentation of cost overruns by percentage, we took great care that the data collected over the years always addressed public money. Therefore, an extension of works that were covered by private sources does not appear, but in turn the extension of investments when private investors dropped out increased the cost overruns. In this case, the overall costs may not have overrun, but it appears as overrun due to additional public money being invested.

\subsection{Quality of Data and Building of Categories}

The available data about the costs and revenues of the Olympic Games and in particular investments for Olympic venues is limited. This study has collected more than 220 sources, but still many data are missing and may not be available at all.

We were able to gather at least for all Games cost estimates from the candidature files and, in most cases, final costs as presented in the official reports. The exceptions are Rio 2016 and PyeongChang 2018, whose Organising Committees are not yet closed, and thus there is no final financial data for the Games. Several times we found cost estimates during the preparation period or the final cost statements in other sources than the official report. We collected them all to display the development of cost and revenue overruns. Missing data could be partly completed by internal data that were made available to us by the IOC Finance Department.

Whenever there was any doubt, we checked for the institution that published the data or started more in-depth research ourselves. For example, we found two different final figures for Sochi 2014 non-OCOG costs: one from the Anti-Corruption Foundation and one from Müller (2014, 631f.). Our research observed that Müller's citation of data did not contain the data he cited from (we used a native Russian speaker to seek and check the sources). Furthermore, none of the official documents about the non-OCOG costs of the 2014 Sochi Winter Games were accessible. Another example is the final costs for Athens 2004. We used the data from Panagiotopoulou (2014), as she had data from the government, which we trusted more than the data from Kasimati (2015).

Categories on OCOGs' costs and revenues were often built differently in various sources. They lacked consistency because the accounting systems were different from Games to Games. Sometimes we even found changes at the same Games when comparing the candidature file to the final cost statements and in-between they sometimes also changed. Then in another official source, costs and revenues were again displayed in a different bundle or even missing. Overall, we found many examples of a missing consistency of data display. 


\subsection{Problems in the Preparation of Data}

Data comparability is possible only when all data are adjusted to a same base year. To do this, we used GDP deflators for OCOG budgets and construction price indexes for non-OCOG budgets.

A construction price index is not available for all countries, and additionally the price index of the different countries is based on different baskets. For our study, that is important because the comparison of the different Games is not our main purpose. As long as we use a consistent "basket" for each Olympic Games, we have robust results to compare the cost and revenue overruns. Further, we could not use one index, because the respective index is always based on the construction situation and material prices in each country. Therefore, it is preferable to use an individual index for each nation.

Table 10 Construction Price Index at Olympic host nations

\begin{tabular}{|c|c|c|c|c|c|c|c|c|c|c|}
\hline & $\mathrm{t}-8$ & $\mathrm{t}-7$ & $t-6$ & $t-5$ & $t-4$ & $t-3$ & $t-2$ & $t-1$ & $t$ & \\
\hline Australia & 50.2 & 49.6 & 51.2 & 53.5 & 55.3 & 57.3 & 59.6 & 61.8 & 63.9 & $\begin{array}{l}\text { Non-dwelling } \\
\text { construction - } \\
\text { New building }\end{array}$ \\
\hline $\begin{array}{l}\text { United } \\
\text { States }\end{array}$ & 474 & 492 & 505 & 525 & 549 & 570 & 595 & 613 & 619 & $\begin{array}{r}\text { Turner Building } \\
\text { Cost Index }\end{array}$ \\
\hline Greece & 85.1 & 89.5 & 94.7 & 98.1 & 100 & 102.2 & 103.8 & 106.2 & 108.7 & $\begin{array}{r}\text { Work categories } \\
\text { price indices for } \\
\text { new residential } \\
\text { buildings } \\
\text { construction }\end{array}$ \\
\hline Italy & $66.8^{*}$ & $68^{*}$ & 70.0 & 71.5 & 74.3 & 76.6 & 79.8 & 83.0 & 85.3 & $\begin{array}{r}\text { new residential } \\
\text { buildings }\end{array}$ \\
\hline China & & & & & & & & & & N/A \\
\hline Canada & & & & & & & & & & N/A \\
\hline $\begin{array}{l}\text { United } \\
\text { Kingdom }\end{array}$ & 160 & 171 & 181 & 193 & 196 & 186 & 188 & $195^{*}$ & $199^{*}$ & $\begin{array}{r}\text { All Construction } \\
\text { Tender Price Index }\end{array}$ \\
\hline Russia & & & & & & & & & & N/A \\
\hline Brazil & & & & & & & & & & N/A \\
\hline Korea & & & & & & & & & & N/A \\
\hline
\end{tabular}

* the value used is interpolated from previous or later values.

Sources: Australian Bureau of Statistics (2018); data360 (2008); Department for Business Innovation and Skills (2012); Eurostat (2018); National Statistical Service of Greece (2007); Turner (n. d.) 
However, for the countries for which no construction price index was available, we used the GDP deflator of the respective country.

Inflation is taken into account using the GDP deflators as displayed in the table below.

Table 11 GDP deflators in Olympic host nations

\begin{tabular}{lrrrrrrrrr}
\hline & $\mathbf{t}-\mathbf{8}$ & $\mathbf{t}-\mathbf{7}$ & $\mathbf{t}-\mathbf{6}$ & $\mathbf{t}-\mathbf{5}$ & $\mathbf{t}-\mathbf{4}$ & $\mathbf{t}-\mathbf{3}$ & $\mathbf{t}-\mathbf{2}$ & $\mathbf{t}-\mathbf{1}$ & $\mathbf{t}$ \\
\hline Australia & 56.0 & 56.4 & 57.0 & 58.3 & 59.8 & 60.6 & 61.3 & 61.6 & 63.1 \\
\hline Brazil & 194.0 & 208.2 & 225.7 & 244.5 & 263.9 & 283.8 & 306.0 & 330.2 & 357.7 \\
\hline Canada & 82.0 & 84.7 & 87.5 & 90.2 & 92.6 & 95.7 & 99.5 & 97.2 & 100.0 \\
\hline China & 58.0 & 59.1 & 59.5 & 61.0 & 65.3 & 67.8 & 70.5 & 76.0 & 82.0 \\
\hline Greece & 63.1 & 67.2 & 70.7 & 73.2 & 74.4 & 77.0 & 79.5 & 82.3 & 84.8 \\
\hline $\begin{array}{l}\text { Italy } \\
\text { Korea }\end{array}$ & 76.9 & 78.1 & 79.7 & 82.0 & 84.8 & 87.5 & 89.7 & 91.4 & 93.1 \\
\hline $\begin{array}{l}\text { Russian } \\
\text { Federation }\end{array}$ & 51.7 & 58.9 & 69.4 & 70.8 & 80.9 & 100.0 & 109.1 & 115.0 & 123.6 \\
\hline $\begin{array}{l}\text { United } \\
\text { Kingdom }\end{array}$ & 86.9 & 89.2 & 91.9 & 94.3 & 97.0 & 98.5 & 100.0 & 102.0 & 103.6 \\
\hline $\begin{array}{l}\text { United } \\
\text { States }\end{array}$ & 72.9 & 74.4 & 75.8 & 77.1 & 77.9 & 79.1 & 80.9 & 82.7 & 84.0 \\
\hline
\end{tabular}

Sources: The World Bank (2018a); Trading economics (2018)

The Olympic Games in Athens (2004) and Turin (2006) were held in Europe, but at the time of planning their budget (1996 and 1998) the euro was not an official currency. We used the first official exchange rate between dollars and euros, which was published in 1999, since no other conversion to the euro was possible. 
Table 12 Exchange rates in the Olympic Games countries t- 8 to $t$

\begin{tabular}{lccccccccc}
\hline & $\mathbf{t}-\mathbf{8}$ & $\mathbf{t}-\mathbf{7}$ & $\mathbf{t}-\mathbf{6}$ & $\mathbf{t}-\mathbf{5}$ & $\mathbf{t}-\mathbf{4}$ & $\mathbf{t}-\mathbf{3}$ & $\mathbf{t}-\mathbf{2}$ & $\mathbf{t}-\mathbf{1}$ & $\mathbf{t}$ \\
\hline Australia & 1.462 & 1.471 & 1.368 & 1.349 & 1.278 & 1.347 & 1.592 & 1.550 & 1.725 \\
\hline Brazil & 1.833 & 1.999 & 1.759 & 1.673 & 1.953 & 2.156 & 2.353 & 3.327 & 3.491 \\
\hline Canada & 1.569 & 1.401 & 1.301 & 1.212 & 1.134 & 1.074 & 1.067 & 1.143 & 1.030 \\
\hline China & 8.279 & 8.277 & 8.277 & 8.277 & 8.277 & 8.194 & 7.973 & 7.608 & 6.949 \\
\hline Greece & N/A & N/A & N/A & 0.939 & 1.085 & 1.118 & 1.063 & 0.886 & 0.805 \\
\hline Italy & N/A & 0.939 & 1.085 & 1.118 & 1.063 & 0.886 & 0.805 & 0.804 & 0.797 \\
\hline Korea & 1156.0 & 1108.2 & 1126.5 & 1094.9 & 1053.0 & 1131.2 & 1160.4 & N/A & N/A \\
\hline $\begin{array}{l}\text { Russian } \\
\text { Federation }\end{array}$ & 27.19 & 25.58 & 24.85 & 31.74 & 30.37 & 29.38 & 30.84 & 31.84 & 38.38 \\
\hline $\begin{array}{l}\text { United } \\
\text { Kingdom }\end{array}$ & 0.546 & 0.550 & 0.543 & 0.500 & 0.544 & 0.642 & 0.647 & 0.624 & 0.633 \\
\hline $\begin{array}{l}\text { United } \\
\text { States }\end{array}$ & 1 & 1 & 1 & 1 & 1 & 1 & 1 & 1 & 1 \\
\hline \hline
\end{tabular}

Source: The World Bank (2018b)

\subsection{Building of OCOG and Non-OCOG Budget Categories}

A comparison of the various Games is very difficult, because each OCOG establishes a different reporting categorisation based on the tradition of their accounting systems. To overcome this difficulty, we grouped all data in a way that the various Games can be compared on the basis of an identical grouping of cost (revenue) categories. The table below shows which costs and revenues are included in each group. The group names will be used in the analysis in the results section.

The following tables show a collection of all nominations of positions in the candidature and later files on the left side. We collected all of them in order to build categories that contain the same information. The category names are shown on the right. 
Table 13 Grouping of OCOG revenues

\begin{tabular}{|c|c|}
\hline Categories of the budget listing & Summarised categories \\
\hline Television Rights & IOC Contribution $^{8}$ \\
\hline Revenues from TOP Programme & TOP Sponsorship \\
\hline $\begin{array}{l}\text { Local Sponsorship } \\
\text { Local/Domestic Sponsorship } \\
\text { Official Suppliers } \\
\text { National Sponsors (1st tier) } \\
\text { National Sponsors (2nd tier) } \\
\text { National Sponsors (3rd tier) }\end{array}$ & National Sponsorship \\
\hline $\begin{array}{l}\text { Revenues from Ticket Sales } \\
\text { Ticket Sales/Ticketing }\end{array}$ & Ticket Sales \\
\hline $\begin{array}{l}\text { Licensing Merchandise } \\
\text { Licensing \& Merchandising/Retail } \\
\text { Consumer Products } \\
\text { Philately } \\
\text { Olympic Coin Programme }\end{array}$ & Licensing \\
\hline Revenues from national and other lotteries & Lotteries \\
\hline $\begin{array}{l}\text { Donations received from third parties without any } \\
\text { attached sponsorship or marketing rights }\end{array}$ & Donations \\
\hline $\begin{array}{l}\text { Revenues from post-Games sales of capital investments } \\
\text { Car \& remaining equipment sales }\end{array}$ & Disposal of assets \\
\hline $\begin{array}{l}\text { Subsidies received from municipal, regional and state authorities } \\
\text { Subsidies - national government } \\
\text { Subsidies - regional government } \\
\text { Subsidies - local government }\end{array}$ & Subsidies \\
\hline $\begin{array}{l}\text { Cultural Activities/Events } \\
\text { Event Revenues } \\
\text { Signature Events } \\
\text { Torch relay Revenues } \\
\text { Paralympic Revenue } \\
\text { Sponsor Hospitality } \\
\text { Sport Publication } \\
\text { Sport Sciences Congress } \\
\text { Accommodation Fees } \\
\text { Food and Beverage Services } \\
\text { Foreign Exchange Revenue } \\
\text { Interest Income } \\
\text { Rate Card Revenue } \\
\text { Mixed Categories } \\
\text { Other }\end{array}$ & Other \\
\hline
\end{tabular}

8 The inflation was calculated in such a way that the total sum of the IOC contribution was paid in the year of the Games. In reality, the payments start four years before, but the largest sum is paid just before the Games. 
Table 14 Grouping of OCOG expenditures

\begin{tabular}{|c|c|}
\hline Categories of the budget listing & Summarised categories \\
\hline $\begin{array}{l}\text { Capital Investments } \\
\text { Sports Facilities/Venues } \\
\text { Olympic Village } \\
\text { Design \& Overlay } \\
\text { Energy Services } \\
\text { Venue Development } \\
\text { Venue Operation }\end{array}$ & Venues \\
\hline $\begin{array}{l}\text { Education } \\
\text { Human Resources } \\
\text { Staffing } \\
\text { Volunteers } \\
\text { Workforce }\end{array}$ & Workforce \\
\hline $\begin{array}{l}\text { Technology } \\
\text { Information Systems } \\
\text { Results Technology Services } \\
\text { Telecommunications } \\
\text { Internet }\end{array}$ & Technology \\
\hline $\begin{array}{l}\text { Medical Services } \\
\text { Catering or Food Services } \\
\text { Transport } \\
\text { Security } \\
\text { Waste Management/Environment Management } \\
\text { Sustainability \& Legacy }\end{array}$ & Services \\
\hline $\begin{array}{l}\text { Ceremonies and Culture } \\
\text { Torch Relay } \\
\text { Advertising \& Promotion } \\
\text { Brand Management } \\
\text { Marketing } \\
\text { Sponsorship } \\
\text { Media } \\
\text { Communication } \\
\text { Games Management } \\
\text { Look of the Games } \\
\text { Ticketing } \\
\text { Sports }\end{array}$ & Marketing \& Events \\
\hline $\begin{array}{l}\text { Administration } \\
\text { CEO Office } \\
\text { Finance } \\
\text { Pre-Olympic Events \& Coordination } \\
\text { Governmental Integration } \\
\text { City Liaison } \\
\text { Protocol }\end{array}$ & Administration \& Coordination \\
\hline
\end{tabular}




\begin{tabular}{ll}
\hline Categories of the budget listing & Summarised categories \\
\hline Accommodation & Other \\
Accreditation & \\
Broadcasting & \\
Contingency & \\
Fixed Payments & \\
Foreign Exchange Gain/Loss & \\
Rate Card & \\
IOC/HOC Royalties & \\
Mixed Categories & \\
Other &
\end{tabular}

The table above is already a reduction of cost items we found in the documents. Overall we found more than 300 different cost items for the 10 Olympic Games we investigated.

Table 15 Grouping of non-OCOG investments

\begin{tabular}{ll}
\hline Categories of the budget listing & Summarised categories \\
\hline $\begin{array}{l}\text { Olympic Stadium } \\
\text { National Stadium }\end{array}$ & Olympic Stadium \\
\hline Swimming Pool & Swimming Pool \\
Aquatic Centre & \\
\hline Basketball Arena & Multipurpose Hall \\
Volleyball Arena & \\
Handball Arena & \\
Gymnastics Arena & \\
\hline $\begin{array}{l}\text { Velodrome } \\
\text { Velopark (including BMX track) }{ }^{10}\end{array}$ & Velodrome \\
\hline Ski Jumping Hill & Ski Jumping Hill \\
\hline Bobsleigh, Skeleton \& Luge & Sliding Centre \\
\hline $\begin{array}{l}\text { Figure Skating \& Short Track } \\
\text { Curling }\end{array}$ & Ice Stadium \\
Ice Hockey & \\
Speed Skating &
\end{tabular}

9 Mixed categories were established when separation of "summarised categories" was not possible.

10 In one case, the Velopark was not subdivided into velodrome and BMX track. Therefore, the BMX track was includ-ed in the evaluation. However, these costs were consistently included from the bidding stage to the final budget, thus the basket remained the same and the potential cost overrun included the Velopark. 


\begin{tabular}{ll}
\hline Categories of the budget listing & Summarised categories \\
\hline Olympic Village & Olympic Village \\
Olympic and Paralympic Village & \\
Main Olympic Village & \\
Mountain Olympic Village & \\
Metropolitan Area Village & IBC \& MPC \\
\hline IBC \& MPC & \\
Media Village &
\end{tabular}

The table above contains the baskets we used for the non-OCOG costs. The label was taken from the above table (summarised categories). In our basket we have taken one of the venues shown on the left, depending on which data were available in the bidding documents. Mostly, the biggest venues were taken. For example, when we write "Ice Stadium", it could be the speed skating venue for one Winter Games and the Ice Hockey Arena for another Winter Games. Since we did not display overall costs, but only the changes, it does not matter if different "Ice Stadium" venues were considered in our basket, as long as we took the costly ones.

The table above displays only the venues we have considered in our baskets. As explained for Sydney 2000 and London 2012, we took only the public money share of the overall investments into account. That leads most probably to an overestimation of cost overruns, because the spending of public money is often not profit driven and less well controlled than that of private investors.

For example, for Sydney 2000, we took only the governmental contribution to the stadium into account and the construction of the stadium itself. In doing so, we missed out the private contribution. Additionally, we did not consider the remediation works and transport and railway connection to the stadium as they are not the direct costs of the "Olympic Stadium" venue.

Open Access This chapter is licensed under the terms of the Creative Commons Attribution 4.0 International License (http://creativecommons.org/licenses/by/4.0/), which permits use, sharing, adaptation, distribution and reproduction in any medium or format, as long as you give appropriate credit to the original author(s) and the source, provide a link to the Creative Commons licence and indicate if changes were made.

The images or other third party material in this chapter are included in the chapter's Creative Commons licence, unless indicated otherwise in a credit line to the material. If material is not included in the chapter's Creative Commons licence and your intended use is not permitted by statutory regulation or exceeds the permitted use, you will need to obtain permission directly from the copyright holder.

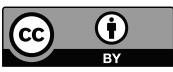




\section{Results I}

The results section is twofold. First, we will look at all Games levels, providing information for each of the 10 investigated Olympic Games. In a second results section, we will look across the various Games, which enables us to suggest interpretations by cost (revenue) groupings or categories. Finally, we present our overall findings.

It should be noted that OCOGs sometimes changed categories in their accounting systems from one year to another. This explains the sudden ups and downs between categories we defined.

\subsection{Sydney 2000}

In September 1993, the IOC awarded Sydney the right to host the Olympic Games in the year 2000. The Olympic Games were held between 15 September and 1 October 2000, and the Paralympic Games between 18 and 29 October. In order to secure the Olympic Games for Sydney, the New South Wales (NSW) Government was required to give an unqualified guarantee that the State would underwrite the Olympic budget. The Government had a responsibility, therefore, to maintain close oversight of the planning for the Olympic Games and implementation of those plans to ensure that essential Olympic facilities were provided on time and within reasonable costs and that the Sydney 2000 Olympic Games were successful.

(C) The Author(s) 2019

$\mathrm{H}$. Preuß et al., Cost and Revenue Overruns of the Olympic

Games 2000-2018, Event- und Impaktforschung, 
All capital investments were made by the NSW Government. Three support and coordination authorities with power to oversee key aspects were established. One was the Olympic Road and Transport Authority (ORTA), the other the Olympic Coordination Authority (OCA), which was in charge of all construction, and lastly another one was the Olympic Security Demand Centre (OSCC). The OCA had the responsibility of coordinating the operational planning and management for those areas in Sydney which fell outside specific Olympic venues, areas collectively known as the Urban Domain.

At the time the Sydney Organising Committee for the Olympic Games (SOCOG) was established, four government ministers and five separate agencies were taking on the NSW Government's Olympic responsibilities. In 1995, action was taken to simplify the management structures. At the end of June 1994, the OCA was formed. The main tasks of the OCA were to deliver venues for the Olympic and Paralympic Games and to coordinate all government involvement regarding Olympic services and programmes needed (OCA 2002, 29). The complexity of this project can be seen in the territories to be coordinated. The OCA was responsible for implementing the planning, redevelopment and management strategies of the 760-hectare Homebush Bay area. It was also responsible for the delivery of new sporting and recreation facilities and venues at Homebush Bay, Penrith Lakes, Blacktown, Bankstown, Horsley Park, Ryde and Cecil Park, which were used during the staging of the Olympic and Paralympic Games (NSW 2000, 8). Following the successful implementation by the OCA, in 2001 a new agency was developed, the Sydney Olympic Park Authority, which is dedicated to running the Olympic Park to this day (NSW, n. d.).

This new coordination model worked out well and was highly appreciated by the IOC. It had the following key elements: A Games "financially underwritten by the Government of New South Wales, a formal and explicit relationship between the Organising Committee, the NSW Government and the Commonwealth of Australia [...], strong state and Commonwealth government coordination mechanisms, backed as far as possible by legislation" (Girginov \& Parry 2005, 237). Both, Athens 2004 and Beijing 2008 involved their governments in the financing and organising of the Games. However, the involvement of the government means using public money and a different ability to control cost overruns.

The starting point of cost estimates is difficult to define for Sydney 2000. The first plans (Tab. 16) found date back to September 1990, three years before the bid. A report to the Premier of NSW shows sometimes higher figures than the official report. This may be due to different planning in the pre-bid phase or it may be a strategically lower announcement of costs in the bid files. This point illustrates the difficulty in determining the best figures for this study.

While the OCA took responsibility for the construction of facilities for the Games, the funding of these facilities was a public and private sector undertaking 


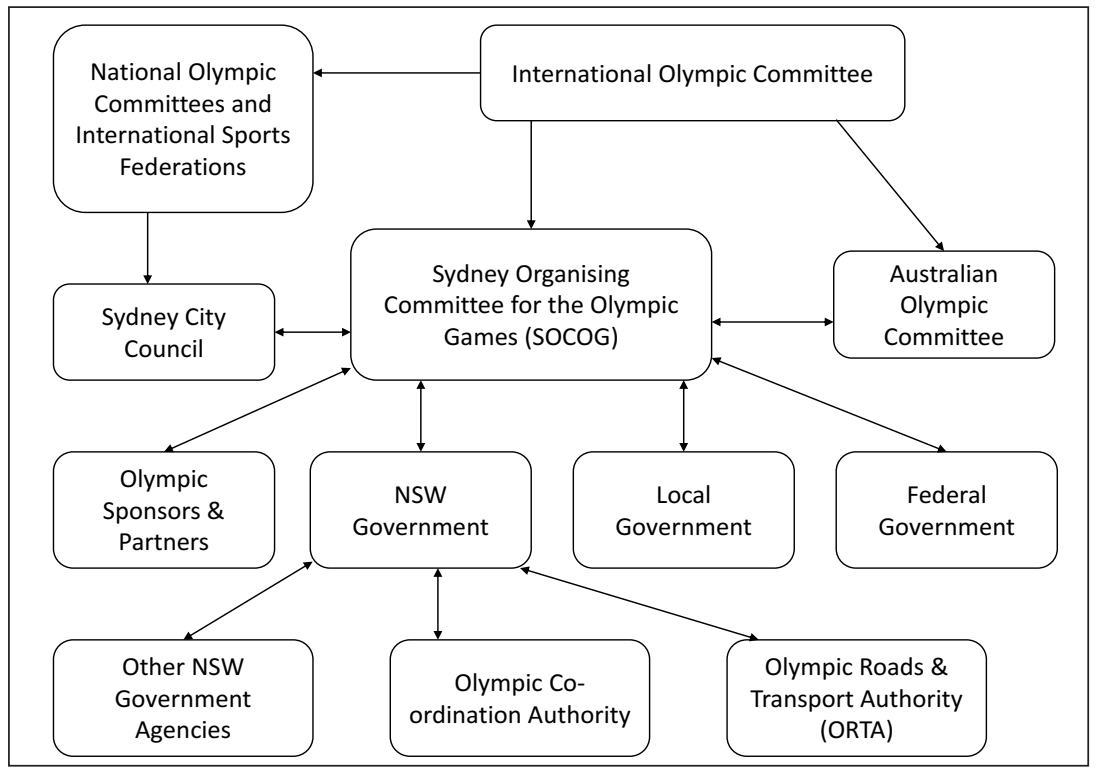

Fig. 10 Organisations involved in the Sydney 2000 Olympic Games Source: State Chamber of Commerce $(2001,11)$

Table 16 Comparison of cost estimates for Sydney 2000 pre-bidding

\begin{tabular}{lcc}
\hline & Sept. 1990 Review Committee & 1993 Bid Limited \\
\hline Velodrome & 32 & million AUD \\
Olympic Stadium & $113-182$ & 17.5 \\
\hline Super Dome & Warm-up \& scoreboard +22 & 190.4 \\
\hline
\end{tabular}

Sources: Sydney Olympic Games Review Committee (1990); Sydney Olympics 2000 Bid Limited (1993)

(PPP). The 110,000-seat Olympic Stadium was finished in February 1999, three months ahead of schedule. The stadium was constructed and funded mainly by the private sector. The project cost was AUD $690 \mathrm{~m}$, with a government contribution of AUD $124 \mathrm{~m}$ to the overall investments (figures are without price index adjustments) (NSW, 2000). As explained above, we consider only the public money share (the 
NSW contribution) regarding cost overruns. For example, the Olympic Stadium (ANZ) had a construction price of USD 583m and a capacity of 83,500 spectators. After the Games were staged, the running track was removed from the stadium in Sydney and its capacity to meet local sporting needs and to be able to host as many events as possible was reduced (Alm 2012, 19).

The OCA and NSW Treasury first published estimates two years prior to the Games because then the cost estimates were quite reliable. Both state agencies published the estimated net impact of the Games on the State's budget in June 1998. AUD $1,650.5 \mathrm{~m}$ according to the OCA (OCA, 1998) and AUD $1,287.5 \mathrm{~m}$ according to the Treasury in NSW (both 1998 AUD). Both the OCA and Treasury updated their estimates each year, but unfortunately these updates were not available for the present study. The important fact here is that the estimate by the Treasury in NSW was AUD 363m less than that presented by the OCA, being the net cost of constructing the Sydney Showground at Homebush Bay. The NSW Treasury did not treat this expenditure as a cost of the Games. Although the OCA's 1998 estimate included this cost, its current report excludes it. The exclusion is consistent with the Audit Office's treatment of these costs in the report entitled Sydney Olympics 2000: Review of Estimates (tabled in Parliament in November 1994). What we learn here is the inconsistency and definition of what must be considered as Olympic-related or not.

Another interesting fact to be mentioned here is that the government did not release the true costs expected, even though it knew at least that costs were higher than announced, which is a typical index of the winner's curse during the bidding process, as the backing of the population is important. While according to the neo-institutionalist PRINCIPAL-AGENT theory, this situation is called "adverse selection". The bidders (the government and the OCA), which are the AGENTS, have an incentive not to provide full information (playing with information asymmetry) to the PRINCIPAL (taxpayers) in order to increase their probability of winning the bid (opportunistic behaviour of the AGENT). For further information, see the neo-institutionalism theory in the theoretical explanations part.

\subsubsection{SOCOG Revenue}

SOCOG was constituted under the Sydney Organising Committee for the Olympic Games Act 1993 in November 1993 and was to be wound up on or before 31 March 2002. In this time, it had the responsibility for the 2000 Olympic Games of:

1. organising accommodation and transport for competitors, team officials and personnel, and media personnel; 
2. organising the sports programme, including preparing and operating all venues and facilities for the Games;

3. organising the cultural programme;

4. establishing a marketing programme, in consultation with the International Olympic Committee and the Australian Olympic Committee;

5. arranging and making available a host broadcaster and television and radio facilities and other information services.

SOCOG earned revenues mainly from sponsorship, ticketing, television rights and government funding, over its period of operation.

Table 17 SOCOG revenue evolution of estimates and final

\begin{tabular}{|c|c|c|c|c|c|c|c|c|}
\hline Categories & $\begin{array}{c}\text { Candidature } \\
\text { File (t-7) } \\
\text { (000 AUD) }\end{array}$ & $t-6$ & $t-5$ & $t-4$ & $t-3$ & $t-2$ & t-1 & $\begin{array}{c}\text { final } \\
\text { (000 AUD) }\end{array}$ \\
\hline IOC Contribution & $\begin{array}{c}0 \% \\
(802,570)\end{array}$ & $-8 \%$ & & & $24 \%$ & $32 \%$ & $32 \%$ & $\begin{array}{c}41 \% \\
(1,132,000)\end{array}$ \\
\hline Sponsorship & $\begin{array}{c}0 \% \\
(488,450)\end{array}$ & $-8 \%$ & & & $77 \%$ & $84 \%$ & $76 \%$ & $\begin{array}{c}40 \% \\
(685,600)\end{array}$ \\
\hline Ticket Sales & $\begin{array}{c}0 \% \\
(228,601)\end{array}$ & $-8 \%$ & & & $122 \%$ & $170 \%$ & $173 \%$ & $\begin{array}{c}166 \% \\
(607,100)\end{array}$ \\
\hline Licensing & $\begin{array}{c}0 \% \\
(83,875)\end{array}$ & $-8 \%$ & & & $-24 \%$ & $-20 \%$ & $-23 \%$ & $\begin{array}{c}-14 \% \\
(72,100)\end{array}$ \\
\hline \multicolumn{9}{|l|}{ Lotteries } \\
\hline \multicolumn{9}{|l|}{ Donations } \\
\hline Disposal of Assets & & & & & & & $0 \%^{11}$ & $\begin{array}{c}137 \% \\
(7,300)\end{array}$ \\
\hline Subsidies & & & & & & & & $\begin{array}{c}0 \% \\
(30,800)\end{array}$ \\
\hline Other & & & & & & $0 \%$ & $-80 \%$ & $\begin{array}{c}744 \% \\
(217,100)\end{array}$ \\
\hline Total & $\begin{array}{c}0 \% \\
(1,603,496)\end{array}$ & $-8 \%$ & & & $52 \%$ & $67 \%$ & $63 \%$ & $\begin{array}{c}72 \% \\
(2,752,000)\end{array}$ \\
\hline
\end{tabular}

Sources: OCA (2002); Sydney Olympics 2000 Bid Limited (1993); SOCOG (1994, 2001, 2002)

11 Explanation: The disposal of assets was mentioned for the first time explicitly only in $\mathrm{t}-1$. So that is why it is $0 \%$, as that is the starting value for this category and we measure the revenue overrun from this point onwards. This method is used in many other Olympic Games categories. 
The SOGOC revenues show a $72 \%$ rate of revenue overrun. There was no funding through a lottery and no donations were registered in favour of the OCOG. In almost all revenue categories more money was generated than originally stated in the Candidature File. The only exception is the licensing and merchandise category. In the ticket sales, disposal of assets and other categories, revenues reach up to more than twice the amount that was actually planned. High revenues from ticket sales is due to the fact that only a small proportion of tickets on free sale were available through a ticket lottery. Many tickets were held for various corporate customers, who paid high ticket prices (Nichols 1999). The drop in some categories from t-1 to final can be explained by the fact that the categories of disposal of assets, subsidies and others rose sharply at the final time or were calculated for the first time only one year before the Games. Where appropriate, these categories were not separated for the first time until the $\mathrm{t}-2$ projection, or these sources of revenue were generated only at a later date, as it became clear that less revenue was expected in some categories (e.g. sponsorship).

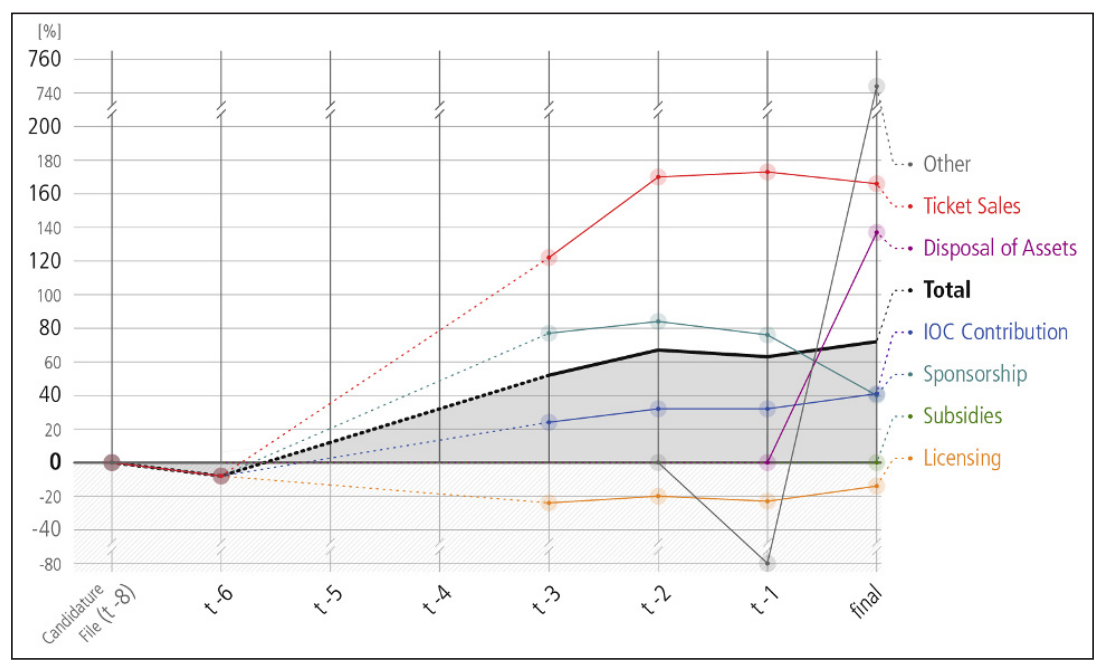

Fig. 11 SOCOG revenue evolution of estimates and final 


\subsubsection{SOCOG Expenditure}

SOCOG already calculated a surplus in its Candidature File, so the budget was never balanced. Nevertheless, the revenues were always higher than the expenditures, even though the percentage information of the revenues seem to be lower than the expenditures at time $\mathrm{t}-3$.

Table 18 SOCOG expenditure evolution of estimates and final

\begin{tabular}{|c|c|c|c|c|c|c|c|c|}
\hline Categories & $\begin{array}{c}\text { Candida- } \\
\text { ture File } \\
(t-7) \\
(000 \text { AUD })\end{array}$ & $t-6$ & $t-5$ & $t-4$ & $t-3$ & $t-2$ & $t-1$ & $\begin{array}{c}\text { final } \\
\text { (000 AUD) }\end{array}$ \\
\hline Venues & $\begin{array}{c}0 \% \\
(208,866)\end{array}$ & $-8 \%$ & & & $89 \%$ & $181 \%$ & $163 \%$ & $\begin{array}{c}203 \% \\
(632,200)\end{array}$ \\
\hline Workforce & $\begin{array}{c}0 \% \\
(78,941)\end{array}$ & $-8 \%$ & & & $-10 \%$ & $-37 \%$ & $-3 \%$ & $\begin{array}{c}-9 \% \\
(71,500)\end{array}$ \\
\hline Technology & & & & & $0 \%$ & $25 \%$ & $27 \%$ & $\begin{array}{c}28 \% \\
(406,300)\end{array}$ \\
\hline Services & $\begin{array}{c}0 \% \\
(151,304)\end{array}$ & $-8 \%$ & & & $240 \%$ & $301 \%$ & $305 \%$ & $\begin{array}{c}103 \% \\
(307,700)\end{array}$ \\
\hline $\begin{array}{l}\text { Marketing } \\
\text { \& Events }\end{array}$ & $\begin{array}{c}0 \% \\
(848,620)\end{array}$ & $-8 \%$ & & & $-48 \%$ & $-55 \%$ & $-59 \%$ & $\begin{array}{c}-46 \% \\
(455,400)\end{array}$ \\
\hline $\begin{array}{l}\text { Administration } \\
\text { \& Coordination }\end{array}$ & $\begin{array}{c}0 \% \\
(23,025)\end{array}$ & $-8 \%$ & & & $343 \%$ & $294 \%$ & $253 \%$ & $\begin{array}{c}481 \% \\
(133,800)\end{array}$ \\
\hline Other & $\begin{array}{c}0 \% \\
(268,072)\end{array}$ & $-8 \%$ & & & $107 \%$ & $92 \%$ & $87 \%$ & $\begin{array}{c}38 \% \\
(371,200)\end{array}$ \\
\hline Total & $\begin{array}{c}0 \% \\
(1,578,827)\end{array}$ & $-8 \%$ & & & $53 \%$ & $66 \%$ & $63 \%$ & $\begin{array}{c}51 \% \\
(2,378,100)\end{array}$ \\
\hline
\end{tabular}

Sources: OCA (2002); Sydney Olympics 2000 Bid Limited (1993); SOCOG (1994, 2001, 2002)

In the venues, technology, services, administration \& coordination and other categories, a cost overrun in the SOCOG budget was recorded, while less was spent than originally planned for workforce and marketing \& events. The changes between the categories may well result from using different subcategories and belonging to different categories. In summary, there was a $51 \%$ total cost overrun of the OCOG expenditures. 


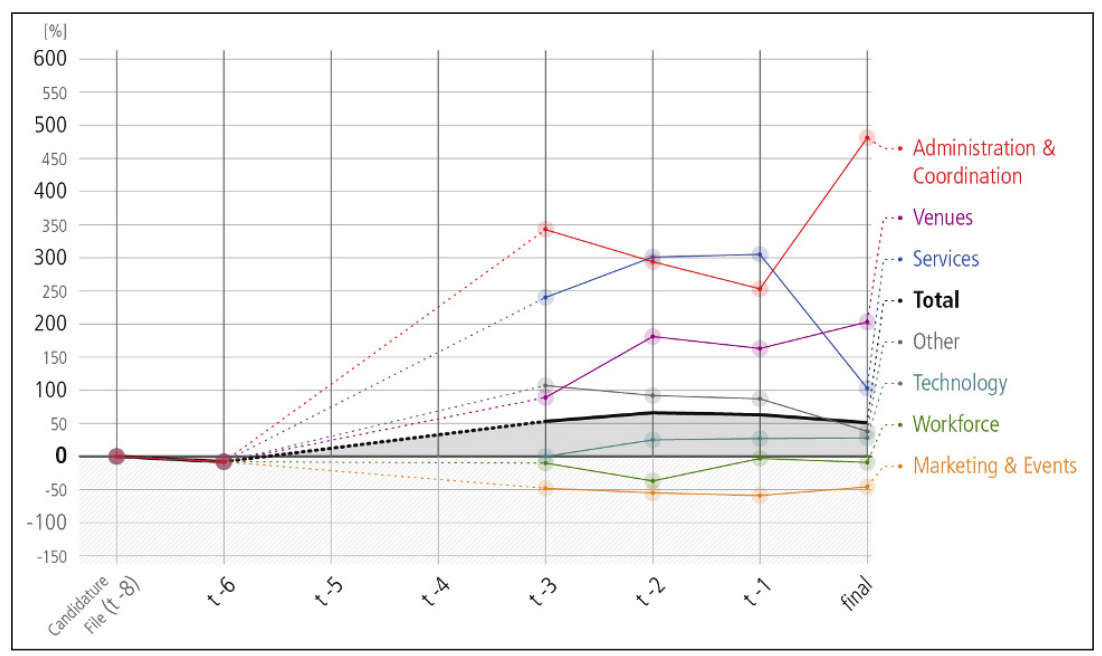

Fig. 12 SOCOG expenditure evolution of estimates and final

\subsubsection{Sydney 2000 Non-OCOG Costs}

SOCOG planned in its Candidature File renovations and new construction of the Olympic Stadium, the multipurpose hall, the velodrome and the Olympic Village. The table above shows only the government's public expenditure. The total cost overruns are calculated on the basis of absolute figures. This means that the velodrome, which has high cost overruns, counts less when looking at all costs of venues in our sample. After all, weighted by the costs of each venue, the government had total cost overruns of $56 \%$ relatively to the promises in the Candidature File.

The costs of the swimming pool were estimated quite well as, in the end, they were $6 \%$ below the estimates. However, as explained above, the costs for the swimming pool were not declared until two years before the Games were staged. To remind the reader of our method: the table above shows for the swimming pool $0 \%$ at $\mathrm{t}-2$, because it was first mentioned then. For the calculation of the overall 56\% cost overrun in Sydney between t-7 and final, the nominal costs of the swimming pool were considered (final) and AUD 0 were put into t-7. Thus the overall percentage reflects the cost overruns in the full amount of the swimming pool. 
Table 19 Sydney 2000 non-OCOG costs evolution of estimates and final from public resources

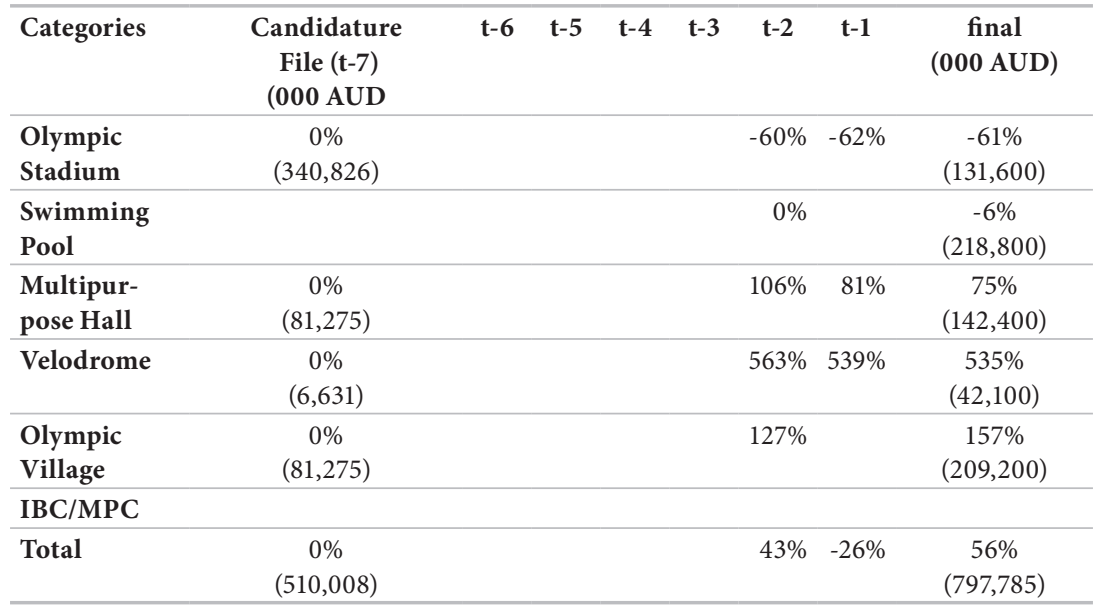

Sources: NSW (2002); OCA (1999, 2002); Sydney Olympics 2000 Bid Limited (1993); The Audit Office of NSW $(1999,2002)$

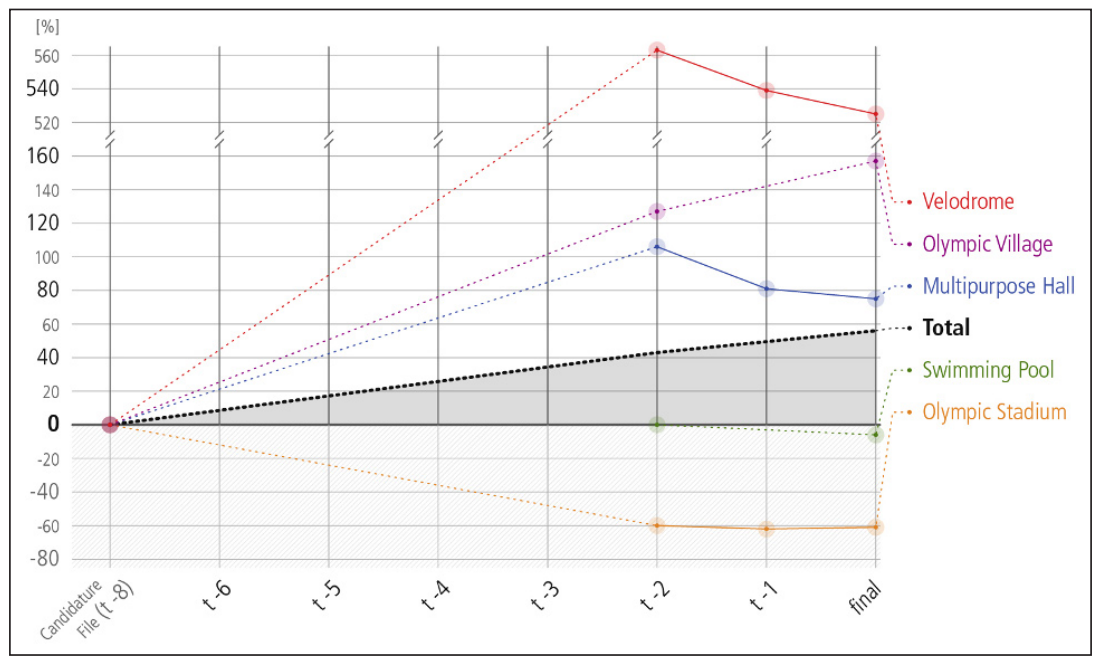

Fig. 13 Sydney 2000 non-OCOG cost evolution of estimates and final from public resources 
The reasons for the increase in costs from the Australian government were (The Audit Office of NSW 1998, 12):

1. the bid was primarily concerned with a successful bid outcome rather than with detailed planning for the delivery of the Games. In this sense, the assumptions within the bid estimates, when measured against current understanding and knowledge, were superficial,

2. improved understanding of the task. Agencies concerned with planning for the Games acquired a greater appreciation of the complexity and extent of the task,

3. estimates took on several changes in their assumptions. The substantial increase in the transport estimate, starting from that included in the bid estimates for example, came about as a result of changed circumstances and assumptions which expanded the role and costs to the government,

4. the number of contests and venues increased,

5. the requirements and configuration of venues changed,

6. the experience of the Atlanta Games resulted in the establishment of new organisations, such as the Olympic Roads and Traffic Authority to coordinate and plan the delivery of transport.

\subsection{Salt Lake City 2002}

All of the Olympic Games in the United States of America have not heavily relied on the support of public money. The highest public support reported was for Lake Placid in 1980, with a share of $50 \%$ of the direct costs. Salt Lake City 2002 was estimated to be $30 \%$ of the total direct costs. Finances were shared by Utah state agencies (8\%) and the Salt Lake City local government (4\%) and 18\% from the federal government (Government Accountability Office (GAO) 2001, 11). However, this money was not all spent on capital investments, but also on transport and security. Only $8 \%$ of the governmental money was spent on infrastructure, namely USD $27 \mathrm{~m}$ on constructing roads to the venues.

Salt Lake City created an "Olympic Opportunities Planning" office. Even though the US Olympic Games should not be financed by public money, the US federal government played a critical role in the staging of the Games. The Congress approved more than USD 240m between 1998 and 2001 for direct Olympic and Paralympic activities. In 2002, President Bush added an additional USD 116m (SLOC 2002b, 9). Fig. 14 shows how the money (projected 2001) was spent. The chart clearly shows that venue building and construction was mostly not paid by 
public money. However, according to Department of Transportation officials, the "construction of the Snowbasin and Winter Sports Park access roads, which are to provide access to the downhill skiing, ski jump, bobsled, and luge venues for the 2002 Olympic Winter Games, would not have been possible, nor would they have been built, without the approximately USD $15 \mathrm{~m}$ specifically designated by Congress" (GAO 2000, 49).

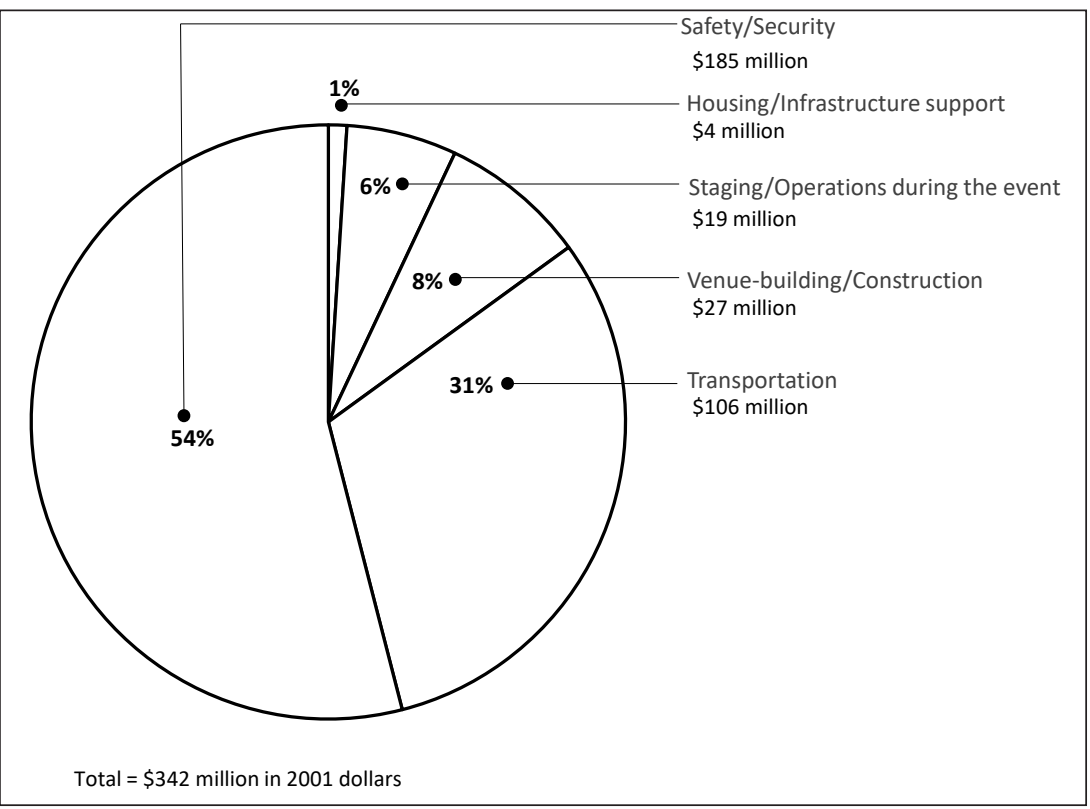

Fig. 14 Total direct cost for projects and activities related to planning and staging the 2002 Olympic and Paralympic Winter Games in Salt Lake City

Source: GAO (2001, 13); Hopkins $(2002,54)$

As of two years before the Games, the federal government planned to provide about USD 1bn in federal funding and support to prepare Salt Lake City for the 2002 Olympic Winter Games. Most of this was provided primarily to develop, build and complete major highway and transit improvement projects (GAO 2000, 40). It is debatable whether these projects were really needed for the Olympic Games or if free riding or opportunism helped to get additional funding for the city and state (see our reflections at the end of this study). 


\subsubsection{SLOC Revenue}

According to the IOC's Host City Contract for the 2002 Olympic Winter Games, Salt Lake City and the United States Olympic Committee (USOC), not the federal government, were responsible for organising the Games. The contract states, in part, that Salt Lake City, the Salt Lake Organising Committee (SLOC) and USOC would be jointly responsible for all commitments concerning the organisation and staging of the Games, with the exception of financing the Games. Financing the Games was the responsibility of both Salt Lake City and the Salt Lake Organising Committee (SLOC). In addition, organisers stated that they were dedicated to hosting the Games with revenue from private sources (GAO 2000, 44).

SLOC's revenue statement shows that it was able to achieve revenue overruns in almost all categories. The exception here is the licensing and merchandise category. In addition, no revenue was generated by an Olympic lottery as one was never created. Overall, Salt Lake City was able to achieve its revenue in all areas. In ticket sales, proceeds from donations, the disposal of assets, subsidies from the government, and the category "other" revenues more than doubled. The percentage for donations and subsidies was so high because only a very small amount was set out in the Candidature File for conservative reasons. The high changes in the estimates in $\mathrm{t}-4$ and $\mathrm{t}-3$ are due to a different categorisation. Overall, the organisation's commission increased its total revenue by $119 \%$.

Table 20 SLOC revenue evolution of estimates and final

\begin{tabular}{|c|c|c|c|c|c|c|c|}
\hline Categories & $\begin{array}{c}\text { Candidature File (t-8) } \\
\text { (000 USD) }\end{array}$ & $t-6$ & $t-5$ & $t-4$ & $t-3$ & $t-2 \quad t-1$ & $\begin{array}{c}\text { final } \\
\text { (000 USD) }\end{array}$ \\
\hline $\begin{array}{l}\text { IOC } \\
\text { Contribution }\end{array}$ & $\begin{array}{c}0 \% \\
(360,970)\end{array}$ & $34 \%$ & & $36 \%$ & $28 \%$ & & $\begin{array}{c}23 \% \\
(443,340)\end{array}$ \\
\hline Sponsorship & $\begin{array}{c}0 \% \\
(358,031)\end{array}$ & $95 \%$ & & $94 \%$ & $57 \%$ & & $\begin{array}{c}89 \% \\
(614,771)\end{array}$ \\
\hline Ticket Sales & $\begin{array}{c}0 \% \\
(95,659)\end{array}$ & $44 \%$ & & $18 \%$ & $100 \%$ & & $\begin{array}{c}112 \% \\
(202,568)\end{array}$ \\
\hline Licensing & $\begin{array}{c}0 \% \\
(46,095)\end{array}$ & $8 \%$ & & $15 \%$ & $-41 \%$ & & $\begin{array}{c}-28 \% \\
(33,200)\end{array}$ \\
\hline \multicolumn{8}{|l|}{ Lotteries } \\
\hline Donations & $\begin{array}{c}0 \% \\
(2,305)\end{array}$ & & & $3643 \%$ & & & $\begin{array}{c}2072 \% \\
(50,070)\end{array}$ \\
\hline $\begin{array}{l}\text { Disposal of } \\
\text { Assets }\end{array}$ & $\begin{array}{c}0 \% \\
(5,788)\end{array}$ & & & & & & $\begin{array}{c}315 \% \\
(24,004)\end{array}$ \\
\hline
\end{tabular}




\begin{tabular}{|c|c|c|c|c|c|c|c|}
\hline Categories & $\begin{array}{c}\text { Candidature File (t-8) } \\
\text { (000 USD) }\end{array}$ & $t-6$ & $t-5$ & $t-4$ & $t-3$ & $t-2 \quad t-1$ & $\begin{array}{c}\text { final } \\
\text { (000 USD) }\end{array}$ \\
\hline Subsidies & $\begin{array}{c}0 \% \\
(34,576)\end{array}$ & & & $0 \%$ & & & $\begin{array}{c}1540 \% \\
(567,000)\end{array}$ \\
\hline Other & $\begin{array}{c}0 \% \\
(16,110)\end{array}$ & $45 \%$ & & $2776 \%$ & $3380 \%$ & & $\begin{array}{c}382 \% \\
(77,603)\end{array}$ \\
\hline Total & $\begin{array}{c}0 \% \\
(919,534)\end{array}$ & $51 \%$ & & $110 \%$ & $96 \%$ & & $\begin{array}{c}119 \% \\
(2,012,556)\end{array}$ \\
\hline
\end{tabular}

Sources: Salt Lake City Bid Committee (1994); SLOC (n. d., 2002a)

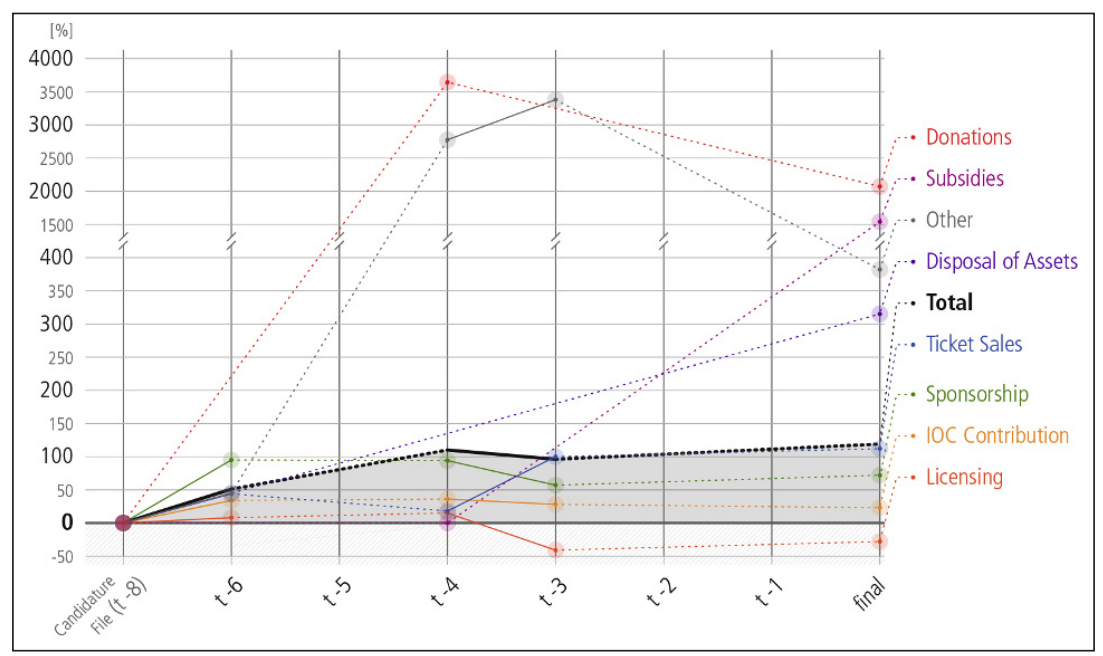

Fig. 15 SLOC revenue evolution of estimates and final

\subsubsection{SLOC Expenditure}

The costs for venues, workforce and technology were decentralised in the Salt Lake City Candidature File in the other categories. These categories were first recorded in its second budget in 1998. Also, four years before the Olympic Winter Games, a small amount of workforce cost was stated, which was probably part of the administration category, which led to such a high cost overrun in the workforce category. SLOC had to pay an early rent for the sports facilities, which becomes apparent in the total costs. In general, many categories had a cost underrun, which is nevertheless overshadowed by the cost overrun of the workforce and services 
categories, which is why the SLOC ultimately had a cost overrun of $114 \%$. The services category had such a high cost overrun because "sustainability" was accounted for the first time and was only placed in this category for the final budget. Security costs, also accounted in the services category, dramatically increased due to higher safety standards after $9 / 11$.

Table 21 SLOC expenditure evolution of estimates and final

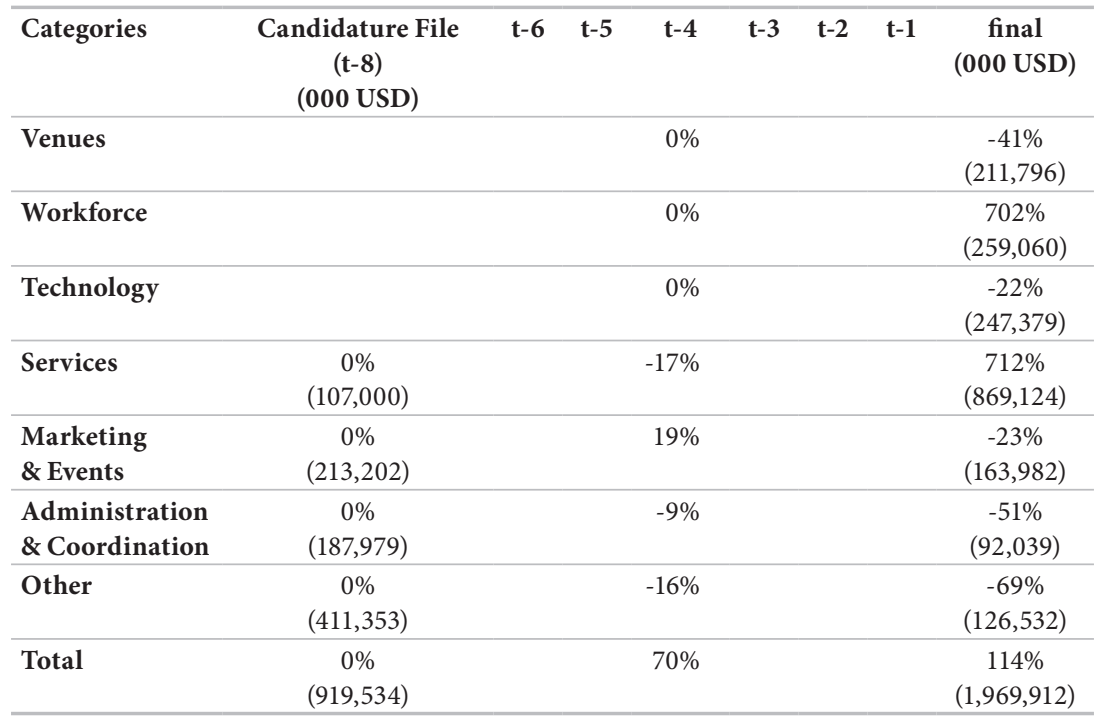

Sources: Salt Lake City Bid Committee (1994); SLOC (1998, 2002a)

A potential reason for cost overruns according to Mitt Romney (CEO of SLOC) was IT, which increased a lot for the Olympic Games. Not only in terms of measuring $1000 / \mathrm{s}$, but providing results instantaneously around the world. In order to reduce the costs, the SLOC downsized many associated programmes around the Games and thus managed to stay within the projected budget (GAO 2001, 54). 


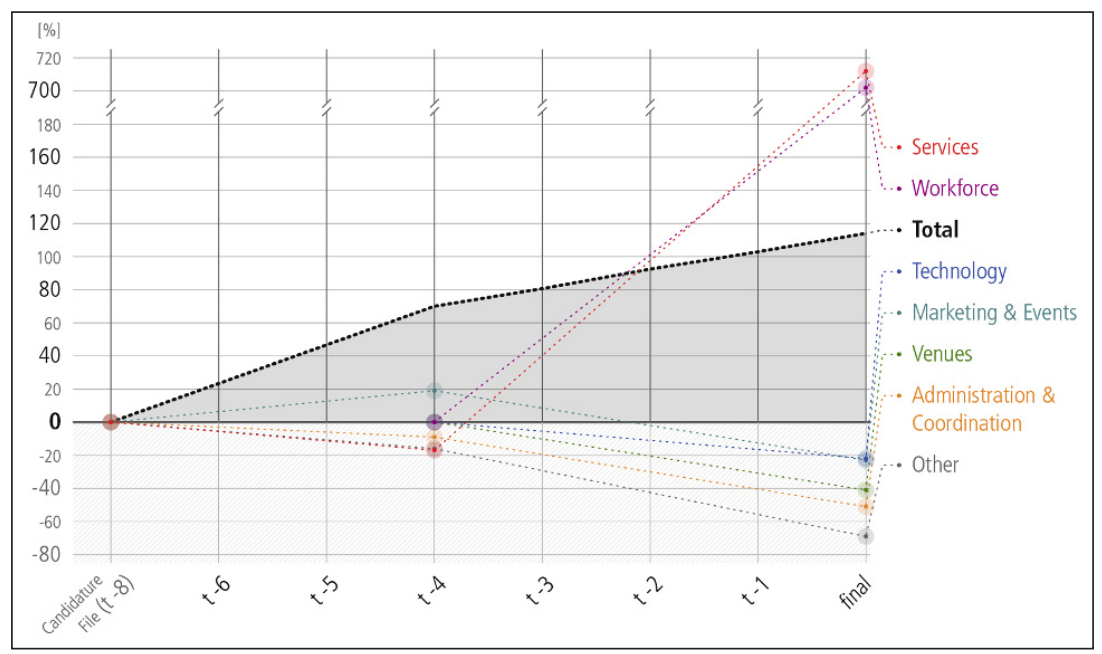

Fig. 16 SLOC expenditure evolution of estimates and final

\subsubsection{Salt Lake City 2002 Non-OCOG Costs}

The analysis of costs is difficult in this case, because Salt Lake City applied for the Olympic Winter Games 1998. Thus, many capital investments were started during the bidding process for the first bid (1989-1991), and venues were completed in 1995, which is the year when Salt Lake City was awarded the 2002 Games. Therefore, the bid book we took as our base does not mention venues such as the Main Media Centre or the Delta Centre (Ice Arena) because they were already completed. Almost $50 \%$ of the capital investments for venues needed to stage the 2002 Winter Games were therefore spent for the first bid to get the Games in 1998 (Salt Lake City Bid Committee 1994).

Another difficulty was the collection of the overall costs of the Games for all involved agencies. There were representatives from about 27 federal agencies involved in preparing Salt Lake City to stage the Games (GAO 2000, 45).

In Salt Lake City, cost overruns are also based on changes of the master plan during the preparations. For example, the SLOC anticipated 9,000 media for the Games. Salt Lake County had an existing venue, but began an expansion of the Main Media Centre (MMC) in 1999 (SLOC 1999, 36).

Our attempt to breakdown each venue that is in our "basket" was highly supported by Fay (2018) (Professor SUNY Cortland, USA) and COO of SLOC Fraser 
Bullock). We found that all venues are still being used in 2018 and virtually all were in place well before the Games in 2002. Some were repurposed for the 2002 Olympic and Paralympic Winter Games and then put back in original use (e.g. Rice Eccles Stadium at the University of Utah used for Opening and Closing Ceremonies and the Salt Palace Convention Centre used for the IBC/MPC for the Games in downtown Salt Lake City). The Rice Eccles Stadium (Olympic Stadium) was expanded in 1998 to 56,000 seats, and it has been reduced back to 46,178 seats today. The costs for that stadium were only USD 67m (Alm 2012, 105).

Other venues that were built for the Games all remain in use still today and are managed by the Utah Olympic Legacy Foundation (e.g. the ski jumps and bob sled/ luge/skeleton run at Utah Olympic Park; the Olympic Oval (speed skating); and Soldier Hollow Cross Country \& Biathlon Centre). The Olympic and Paralympic Village at historic Ft. Douglas is now used as residence halls for the University of Utah. What is unique to Salt Lake is its vision in 1989 to fund these venues regardless of whether or not the city was ultimately awarded an Olympic bid (Fay 2018). And this is what happened, as Salt Lake did not get the Games for 1998. This means that the venue costs and their displayed cost overruns cannot be counted as Olympic costs, or at least it is difficult to calculate cost overruns for the 2002 Games when venues already existed during the bid.

Due to few public investments, little data were available on the Salt Lake City venues in our "basket" for this study. Therefore, we also used some less trustworthy sources, such as newspapers, to triangulate the figures we obtained. Fay (2018) conducted comprehensive research from public sources such as newspapers (Salt Lake City Tribune and the Deseret News) and some other articles. These sources were double-checked whenever possible by using several newspapers and then compared to the data we gathered from the Organising Committee.

SLOC used a public-private partnership model that involved a combination of state (public), non-profit (University of Utah) and private funding in order to build out the Games and then to manage many of these venues afterwards. For example, the Utah Olympic Park is currently undergoing a major upgrade and expansion.

The table 22 considers the Ice Sheet Ogden (curling) as an "Ice Stadium" because it incurred higher construction costs than the Olympic Oval and it was considered in the bid book, thus we had a starting point. COO Fraser Bullock stressed that the Delta Centre (Ice Stadium for figure skating) was built for an NBA basketball team, the Utah Jazz. It was not built for the Olympic Games, and only USD 2 million was paid by SLOC for rent. Overall, this research found that much of the construction in Utah would have happened without the Games and should not be counted as Olympic costs. 
Table 22 Salt Lake City 2002 non-OCOG cost evolution of estimates and final from public resources

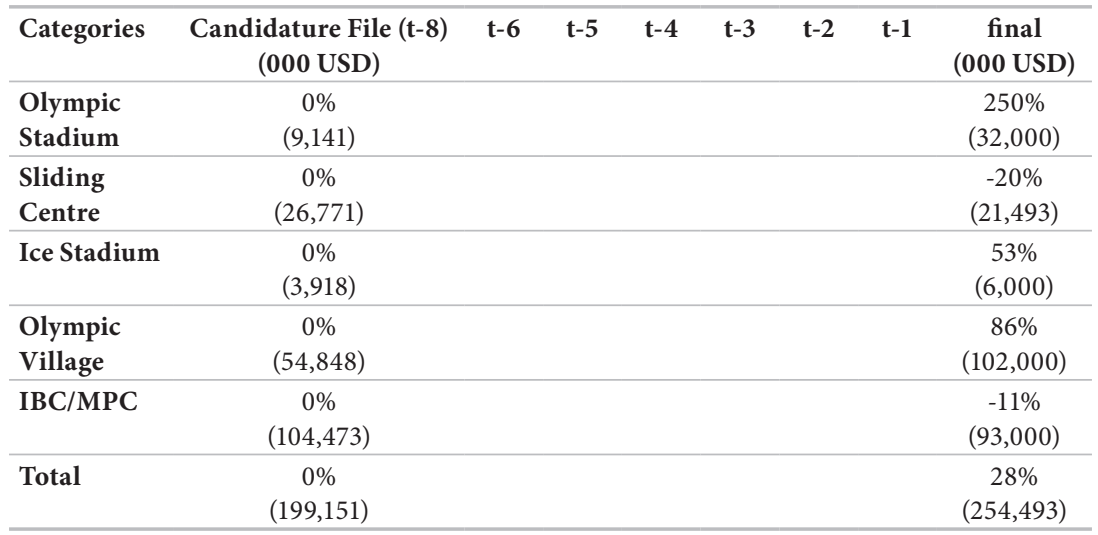

Sources: Fay (2018); Roche (1994); Salt Lake City Bid Committee (1994); SLOC (2001)

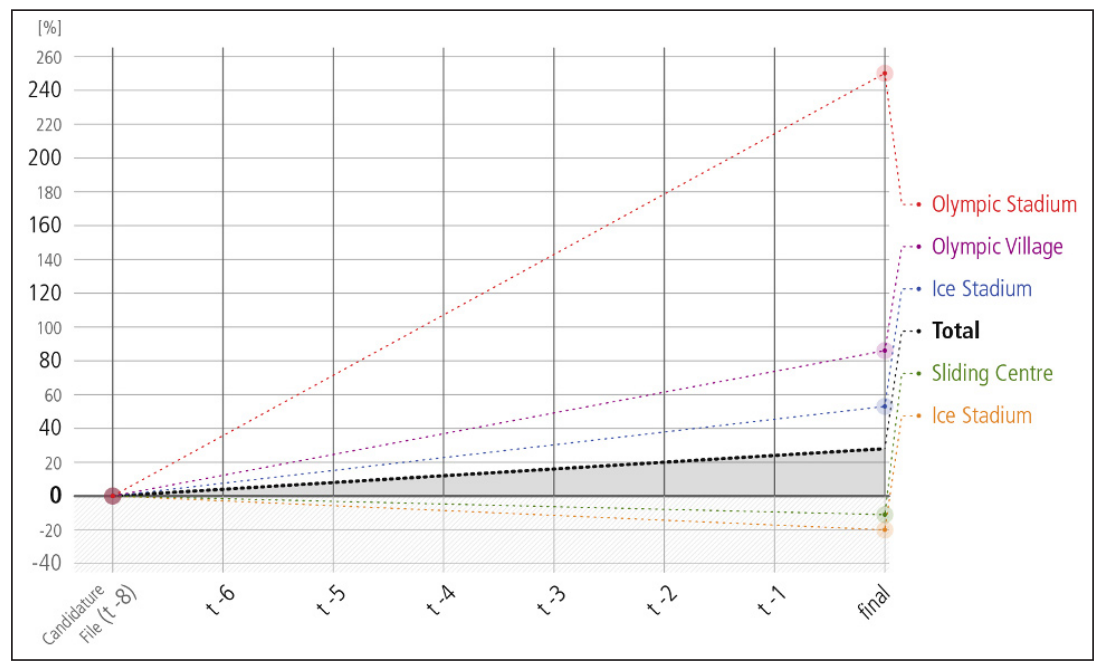

Fig. 17 Salt Lake City 2002 non-OCOG cost evolution of estimates and final from public resources 


\subsection{Athens 2004}

Athens was selected by the IOC to host the Olympic Games on 5 September 1997 in Lausanne, where the Host City Contract between the IOC and the City of Athens was signed. Regarding planning and cost estimates, it is important to note that Athens had unsuccessfully bid for the Olympic Games of 1996, which coincided with the 100th anniversary of the modern Olympic Games. Thus, the bidding and planning started nine years beforehand. However, the true preparation effort intensified from 2000 onwards with great time pressure.

Apart from Athens, another four Olympic cities - Thessaloniki, Volos, Patras and Heraklion - hosted football matches. In Athens, two large complexes of athletic venues hosted most of the events of the Olympic Games 2004: the Olympic Athletic Centre of Athens and the Hellinikon Olympic Comples. The Games events were held in 32 venues, of which 18 were newly constructed, 12 were renovated and only 2 were temporary facilities. This put a high investment burden on Athens (Foundation for Economic \& Industrial Research (IOBE) 2015, 28).

While the government took the responsibility for the construction of the sports venues for the Games, their funding was a public and private sector undertaking (Kasimati 2015, 169). The financing of the projects for the Athens Olympic Games was finally mainly covered by the State Budget (Public Investment Programme and Ordinary Budget) and by the revenues of the Athens 2004 Organising Committee for the Olympic Games (ATHOC). The construction of the Olympic Village was financed by the Worker's Housing Organisation (OEK). A fourth source of financing, which is, however, very small compared with the other sources, is the private sector, as some Olympic projects were self-financed (IOBE 2015, 43).

The Olympic venues for the Olympic Games in Athens 2004 were financed by several authorities:

1. Ministry of Environment, Physical Planning and Public Works (YPEHODE),

2. General Secretariat for the Olympic Utilisation (Ministry of Culture),

3. General Secretariat of Sports,

4. Special Service for Public Works.

The next figure shows how many ministries were involved. 


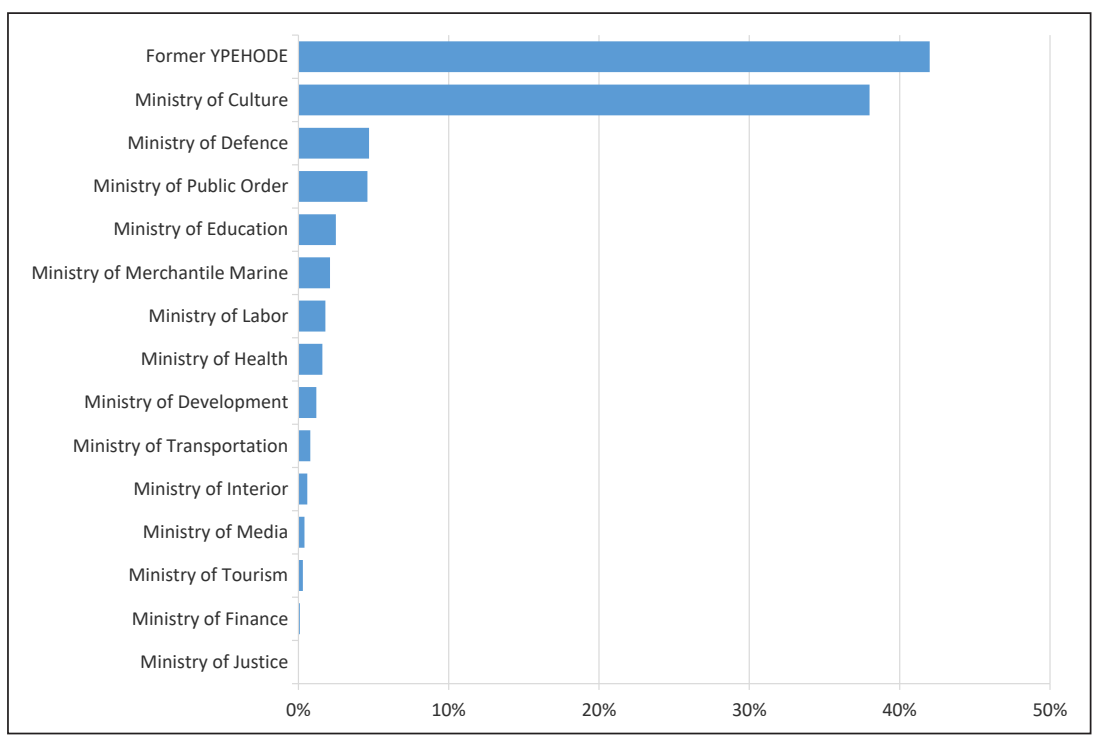

Fig. 18 Expenditure for the preparation of the 2004 Olympic Games by Ministry Source: Ministry of Finance quoted by $\operatorname{IOBE}(2015,48)$

Regarding to the allocation of expenditure by Ministry, the cumulative share of the Ministry of Culture and of the former YPEHODE reached almost $80 \%$ of the total expenditure. However, Panagiotopoulou $(2014,177)$ speaks of three ministries involved in the financing of the Olympic works: the YPEHODE, the Ministry of Culture and the Ministry of Transport.

There is controversy about the usefulness of infrastructural development. On the one hand, great infrastructure projects which had developed only slowly for years like the new subway, bypasses and the future major airport received great impetus from the pressing date of the Olympic Games. On the other hand, however, there is the threat of irreversible planning errors due to time pressure or infringements of social principles by special regulations (Lenskyj 2000).

It is important to note that according to the $\operatorname{OECD~(n.~d.):~}$

"Athens is benefiting from investments for the 2004 Olympic Games but it needs clear strategic planning to take advantage of the opportunities that globalisation and eastward expansion of the European Union will bring. Organising the Olympic Games has proved to be a unique challenge not only for Greece's capital city but for the entire national administration. [...] Preparations for the Olympic Games in August 
2004 and financing from EU Community Support Funds have boosted investment in the hotel sector, year-round sports facilities and a modern region-wide transport network. This includes a brand new international airport, urban highways and ring roads to decrease congestion, upgraded rail links, a new metro, a non-polluting bus fleet, and tramway lines which connect the city centre and the suburbs. A programme to enhance architectural heritage and environmental assets has transformed central Athens and the area around the Acropolis. Like Barcelona, Athens now boasts easy access to a landscaped coastal zone at Faliron which offers a wide range of leisure and sports activities."

\subsubsection{ATHOC Revenue}

The Athens 2004 Organising Committee for the Olympic Games (ATHOC) - with the distinctive name "Athens 2004 S.A." - was a private legal entity with the legal form of an anonymous society. The entity was established in March 1998 with Law 2598/98, with the Greek government as the sole shareholder, and was dissolved in May 2005. Thus the Greek government was responsible for supervising Athens 2004 S.A., through an inter-ministerial committee. ATHOC, according to the Host City Contract, was responsible for planning and coordinating the preparation and the management of the Olympic and Paralympic Games. Among its main responsibilities was to ensure that the construction of the facilities associated with the Games complied with the applicable specifications and time schedules, in accordance with the regulations set out by the IOC (IOBE 2015, 31).

Looking at the ATHOC revenue, it is noticeable that almost all categories of revenue were included in the Candidature File. Only subsidies from the government were added the first time in the final budget, thus it shows a $0 \%$ change. In almost all categories, ATHOC achieved a revenue overrun. The TOP Sponsorship and other categories more than doubled their revenue. Furthermore, the number of national sponsors was low, but these sponsors contributed with higher contributions. The generation of lottery revenues was problematic. Originally a lottery was to be offset up for the Olympic Games. But this lottery was never set up, yet the Greek state was obliged to pay a share to ATHOC under the contractual arrangements. Similarly, the Greek state had to provide funding for missing revenue at the end of the Games in order to pay all the costs incurred. However, this contribution by the state was paid back by the profit at the end of the Games by ATHOC. In summary, ATHOC generated $51 \%$ more revenue than it had forecast. The major element for increasing revenue was the foreign exchange gains as the foreign exchange rate (USD to euro) turned favourably to the OCOG. 
Table 23 ATHOC revenue evolution of estimates and final

\begin{tabular}{|c|c|c|c|c|c|c|c|c|}
\hline Categories & $\begin{array}{c}\text { Candidature } \\
\text { File (t-8) } \\
\text { (000 EUR) }\end{array}$ & $t-6$ & $t-5$ & $t-4$ & $t-3$ & $t-2$ & $t-1$ & $\begin{array}{c}\text { final } \\
(000 \text { EUR) }\end{array}$ \\
\hline $\begin{array}{l}\text { IOC } \\
\text { Contribution }\end{array}$ & $\begin{array}{c}0 \% \\
(560,360)\end{array}$ & & & $49 \%$ & $45 \%$ & $37 \%$ & $33 \%$ & $\begin{array}{c}3 \% \\
(578,700)\end{array}$ \\
\hline $\begin{array}{l}\text { Top Sponsor- } \\
\text { ship }\end{array}$ & $\begin{array}{c}0 \% \\
(104,188)\end{array}$ & & & $156 \%$ & $162 \%$ & $154 \%$ & $145 \%$ & $\begin{array}{c}117 \% \\
(225,800)\end{array}$ \\
\hline $\begin{array}{l}\text { National } \\
\text { Sponsorship }\end{array}$ & $\begin{array}{c}0 \% \\
(267,509)\end{array}$ & & & $-15 \%$ & $-1 \%$ & $0 \%$ & $-4 \%$ & $\begin{array}{c}16 \% \\
(310,900)\end{array}$ \\
\hline Ticket Sales & $\begin{array}{c}0 \% \\
(187,725)\end{array}$ & & & $15 \%$ & $7 \%$ & $4 \%$ & $0 \%$ & $\begin{array}{c}3 \% \\
(194,000)\end{array}$ \\
\hline Licensing & $\begin{array}{c}0 \% \\
(72,274)\end{array}$ & & & $-10 \%$ & $11 \%$ & $15 \%$ & $11 \%$ & $\begin{array}{c}15 \% \\
(82,900)\end{array}$ \\
\hline Lotteries & $\begin{array}{c}0 \% \\
(220,577)\end{array}$ & & & $21 \%$ & $17 \%$ & $14 \%$ & $10 \%$ & $\begin{array}{c}28 \% \\
(282,500)\end{array}$ \\
\hline Donations & $\begin{array}{c}0 \% \\
(18,773)\end{array}$ & & & $21 \%$ & $17 \%$ & $-43 \%$ & $-45 \%$ & $\begin{array}{l}-99 \% \\
(200)\end{array}$ \\
\hline $\begin{array}{l}\text { Disposal of } \\
\text { Assets }\end{array}$ & $\begin{array}{c}0 \% \\
(18,773)\end{array}$ & & & & $-6 \%$ & $175 \%$ & & $\begin{array}{c}7 \% \\
(20,000)\end{array}$ \\
\hline Subsidies & & & & & & & & $\begin{array}{c}0 \% \\
(191,400)\end{array}$ \\
\hline Other & $\begin{array}{c}0 \% \\
(58,195)\end{array}$ & & & $-2 \%$ & $127 \%$ & $117 \%$ & $320 \%$ & $\begin{array}{c}574 \% \\
(392,400)\end{array}$ \\
\hline Total & $\begin{array}{c}0 \% \\
(1,508,374)\end{array}$ & & & $30 \%$ & $43 \%$ & $39 \%$ & $34 \%$ & $\begin{array}{c}51 \% \\
(2,278,800)\end{array}$ \\
\hline
\end{tabular}

Sources: Athens 2004 Olympic Bid Committee (1996); ATHOC (2003, 2004, 2005a, b) 


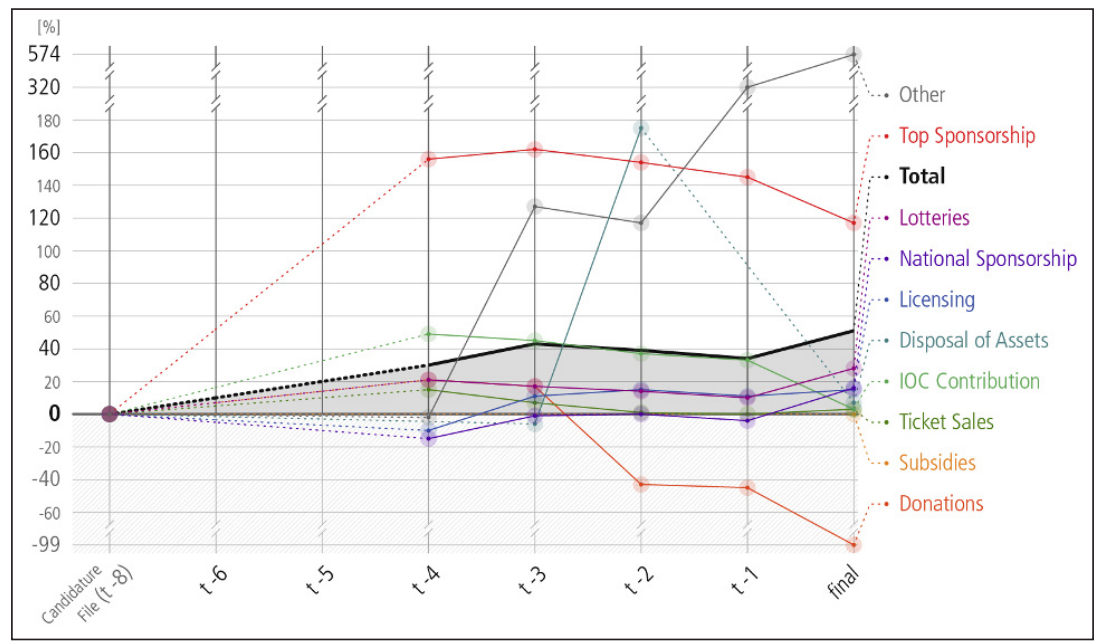

Fig. 19 ATHOC revenue evolution of estimates and final

\subsubsection{ATHOC Expenditure}

The total expenditure overruns were quite stable from 2000 onwards at $30 \%$. However, a year before the Games, we can observe large changes. Marketing \& Events fourfold, but other expenditures were cut down tremendously. The reason might be that the categorisation was not consistent at t-1 in comparison to the other cost estimates.

ATHOC had an overall cost overrun of $30 \%$. The categories workforce and technology weren't included in the candidature file respectively they added them into other categories and decentralised them. Actually the paid staff costs were all the time decentralised. The differences in the budget projection one year prior to the Games occur due to the inconsistency in illustrating the costs. These changes can also be explained by the inconsistent presentation of the budget. One of the reasons the expenditure for marketing and events increased was that ATHOC planned at a late stage to organise a torch relay all around the world in all former Olympic cities, returning back to its origins in Athens. 
Table 24 ATHOC expenditure evolution of estimates and final

\begin{tabular}{|c|c|c|c|c|c|c|c|c|}
\hline Categories & $\begin{array}{c}\text { Candidature } \\
\text { File (t-8) } \\
\text { (000 EUR) }\end{array}$ & $t-6$ & $t-5$ & $t-4$ & $t-3$ & $t-2$ & $t-1$ & $\begin{array}{c}\text { final } \\
(000 \text { EUR) }\end{array}$ \\
\hline Venues & $\begin{array}{c}0 \% \\
(532,108)\end{array}$ & & & $-53 \%$ & $-54 \%$ & $-64 \%$ & $-65 \%$ & $\begin{array}{c}-46 \% \\
(287,200)\end{array}$ \\
\hline Workforce & & & & $0 \%$ & $200 \%$ & $82 \%$ & & $\begin{array}{c}179 \% \\
(55,400)\end{array}$ \\
\hline Technology & & & & $0 \%$ & $4 \%$ & $-9 \%$ & $-12 \%$ & $\begin{array}{c}-21 \% \\
(309,900)\end{array}$ \\
\hline Services & $\begin{array}{c}0 \% \\
(206,498)\end{array}$ & & & $-50 \%$ & $-8 \%$ & $-18 \%$ & & $\begin{array}{c}23 \% \\
(253,900)\end{array}$ \\
\hline $\begin{array}{l}\text { Marketing \& } \\
\text { Events }\end{array}$ & $\begin{array}{c}0 \% \\
(300,361)\end{array}$ & & & $57 \%$ & $64 \%$ & $63 \%$ & $238 \%$ & $\begin{array}{c}52 \% \\
(457,400)\end{array}$ \\
\hline $\begin{array}{l}\text { Administration } \\
\text { \& Coordination }\end{array}$ & $\begin{array}{c}0 \% \\
(170,830)\end{array}$ & & & $28 \%$ & $80 \%$ & $92 \%$ & $106 \%$ & $\begin{array}{c}42 \% \\
(243,000)\end{array}$ \\
\hline Other & $\begin{array}{c}0 \% \\
(298,577)\end{array}$ & & & $70 \%$ & $55 \%$ & $74 \%$ & $-57 \%$ & $\begin{array}{c}21 \% \\
(361,000)\end{array}$ \\
\hline Total & $\begin{array}{c}0 \% \\
(1,508,374)\end{array}$ & & & $30 \%$ & $43 \%$ & $39 \%$ & $34 \%$ & $\begin{array}{c}30 \% \\
(1,967,800)\end{array}$ \\
\hline
\end{tabular}

Sources: Athens 2004 Olympic Bid Committee (1996); ATHOC (2003, 2004, 2005a, b)

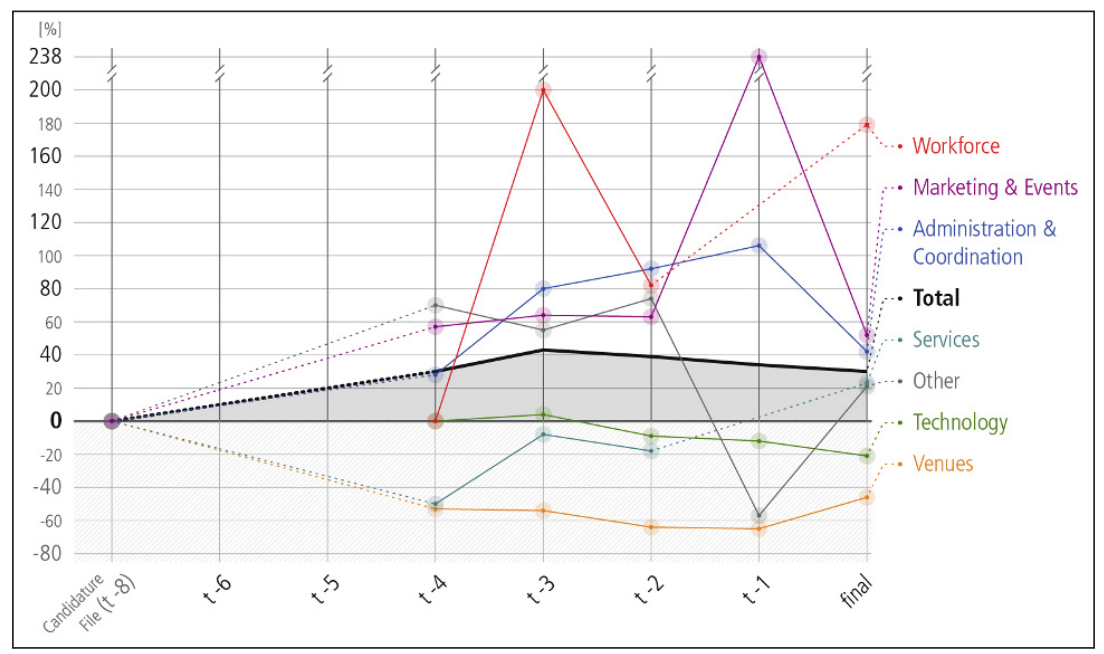

Fig. 20 ATHOC expenditure evolution of estimates and final 
ATHOC took over the services and supply of goods for and on behalf of the Greek State for EUR $303.8 \mathrm{~m}$ and received subsidies of EUR $180.2 \mathrm{~m}$. The deficit of EUR $123.6 \mathrm{~m}$ was covered by ATHOC's profit, which then closed its accounts with a final surplus of EUR 7m (all in 2005 euros, ATHOC 2005a).

\subsubsection{Athens 2004 Non-OCOG Costs}

The implementation of construction projects was the responsibility of the Greek government. From 2000 onwards, ATHOC signed memoranda of understanding with each ministry separately, aiming to accelerate the execution of projects that had fallen behind schedule (IOBE 2015, 32).

According to the state budget reports, the state financing for the projects classified as Olympic came exclusively from the domestic resources of the Public Investment Programme (PIP), without financing from EU funds. The list of projects financed by the PIP includes the construction of new (and the upgrade of existing) sports facilities for staging sports events, along with auxiliary equipment and infrastructure. The expenditure for the procurement of equipment for the police and other government agencies to ensure security during the Games is also included here. The state financing also includes the construction cost of the transport network (technical studies, land expropriation, road infrastructure) necessary for connecting the sports and other facilities with the main road network of Athens. Public funds were also used to improve access to historical and cultural sites. This study concentrates solely on the sports venues as defined in the "basket". This means that cost overruns in the many other projects are not covered in the figures presented below.

In addition, the PIP includes the contribution of EUR $282.5 \mathrm{~m}$ from the Greek State to the ATHOC budget for the preparation and staging of the Olympic and Paralympic Games, as per a decision by the inter-ministerial committee, DESOP. The subsidy aimed to cover the gap in the ATHOC budget from the cancellation of plans for an "Olympic lottery", which had stirred acute political controversy (IOBE $2015,44)$. These funds are displayed above (ATHOC revenues) in the "Lottery" category and not in "Subsidies".

Additionally, on the occasion of the 2004 Olympic Games, the Greek State financed a substantial number of relatively low-scale projects, compared with the other categories, aiming to upgrade existing infrastructure (e.g. hospitals in Athens, public transport) and perform repair and reconstruction work in many areas of Athens (e.g. creating pedestrian zones, repairing roads and avenues, performing work on public parks, planting trees and restoring buildings). The Greece 2004 programme is also included here, with regional projects (e.g. upgrade of sports 
facilities, cultural initiatives). The EU indirectly funded general infrastructure that was useful for the Games, but nothing directly related. A large programme of infrastructure works and industry development projects (a new airport, metro, tram, suburban railway, motorway system and upgraded road network) was implemented in the greater Athens area, and part of this was funded through the Community Support Framework (CSF) of the European Union for the general improvement of the city's infrastructure (Kasimati 2015, 172).

The following table and figure shows the changes of costs from the candidature to the final costs.

Table 25 Athens 2004 non-OCOG cost evolution of estimates and final from public resources $^{12}$

\begin{tabular}{|c|c|c|c|c|c|c|c|c|}
\hline Categories & $\begin{array}{c}\text { Candidature } \\
\text { File (t-8) } \\
\text { (000 EUR) }\end{array}$ & $t-6$ & $t-5$ & $\mathrm{t}-4$ & $t-3$ & $t-2$ & $t-1$ & $\begin{array}{c}\text { final } \\
\text { (000 EUR) }\end{array}$ \\
\hline Olympic Stadium & & & & & & & & $(398,900)$ \\
\hline Swimming Pool & & & & & & & & $(24,243)$ \\
\hline Multipurpose Hall & & & & & & & & $(35,836)$ \\
\hline Velodrome & & & & & & & & N/A \\
\hline IBC/MPC & & & & & & & & $(200,732)$ \\
\hline Olympic Village & $\begin{array}{c}0 \% \\
(395,646)\end{array}$ & & & & & & & $\begin{array}{c}-27 \% \\
(287,900)\end{array}$ \\
\hline Shooting Centre & $\begin{array}{c}0 \% \\
(13,188)\end{array}$ & & & & & & & $\begin{array}{c}328 \% \\
(56,389)\end{array}$ \\
\hline Equestrian Centre & $\begin{array}{c}0 \% \\
(21,581)\end{array}$ & & & & & & & $\begin{array}{c}439 \% \\
(116,246)\end{array}$ \\
\hline Tennis Court & $\begin{array}{c}0 \% \\
(10,790)\end{array}$ & & & & & & & $\begin{array}{c}418 \% \\
(55,911)\end{array}$ \\
\hline Football Stadium & $\begin{array}{c}0 \% \\
(28,774)\end{array}$ & & & & & & & $\begin{array}{c}97 \% \\
(56,724)\end{array}$ \\
\hline Weightlifting Hall & $\begin{array}{c}0 \% \\
(11,390)\end{array}$ & & & & & & & $\begin{array}{c}332 \% \\
(49,240)\end{array}$ \\
\hline Total & $\begin{array}{c}0 \% \\
(481,370)\end{array}$ & & & & & & & $\begin{array}{c}29 \% \\
(622,410)\end{array}$ \\
\hline
\end{tabular}

Sources: Athens 2004 Olympic Bid Committee (1996), ATHOC (n. d.); Kasimati (2015), Panagiotopoulou (2014)

12 Additional venues were considered. 
The table includes absolute figures for those venues that had a lack of cost estimates in the candidature file. These absolute figures are intended simply to give an overview of the final costs according to the "basket" that we usually investigate. What is interesting is that the bidding committee did not plan to spend public resources on core Olympic venues. Due to the lack of data for our "basket", we changed the components of the basket on one occasion, but kept the Olympic Village in it. Although the final costs of the other venues are available, these cannot be included in our calculations, because we have no bid book data about these venues. To present here a percentage for cost overruns, we changed our basket solely for Athens 2004. The basket contains the Olympic Village, the Shooting Centre, the Equestrian Centre, the Tennis Court, one Football Stadium and the Weightlifting Hall. Overall, it was only $29 \%$ more costly than planned. Unfortunately, no data could be found showing intermediate cost estimates.

According to other sources addressing cost overruns, both PricewaterhouseCoopers $(2004,22)$ and Panagiotopoulou $(2014,178)$ found similar cost overruns as we did, at around $25 \%$. The table above shows different overruns by project. Almost all venues we considered had a cost overrun, with noticeably high cost overruns. Only the cost for the construction of the Olympic Village fell below the original plans. This explains the relatively low $29 \%$ overall cost overrun because the Village was so expensive that its weight on the total sum led to a moderate percentage.

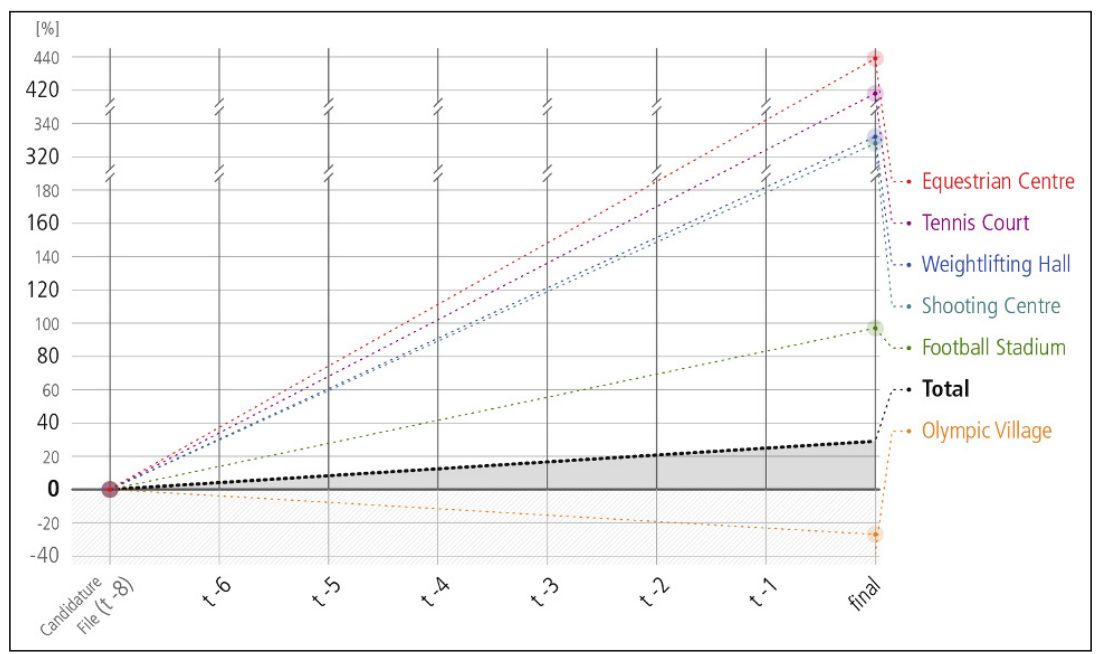

Fig. 21 Athens 2004 non-OCOG cost evolution of estimates and final from public resources 
From Athens 2004 we can learn two facts. Firstly, many venues were not considered, or at least the bidding committee thought to use existing facilities or $100 \%$ private resources to construct them. Secondly, there are differences and problems in differentiating the costs of the individual sports facilities. For example, the cost of the Olympic Stadium was estimated at EUR 23m, with the additional costs of aesthetic enhancement and functional change of around EUR 361m (Panagiotopoulou, 2014, 178; Pollalis 2006, 9).

When discussing cost overruns in Greece, an important factor is mentioned by Cartalis (2015). He argues that the land ownership pattern is important when areas are picked to serve as Olympic infrastructure. The existence of publicly owned land within the urban area facilitates the integration of Olympic projects (and related capital investments) into the city; on the contrary, the case of Athens 2004 showed a lack of such areas. That limited the potential for extensive urban regeneration projects and increased the financial burden of the public authorities, because the necessary expropriations usually incurred high costs, due to the elevated market demand for available areas. Finally, this caused time constraints because, for a long time, construction could not start.

This explains the second cost driving factor, which is time pressure. The need to accelerate the construction of the projects may have led to higher costs, compared to a hypothetical scenario, in which the allocation of the projects in the preparation period had been more even. In general, we can say that unpredictable and uncertain factors may generate delays in the project achievement - which is often the case in the building and construction industry. Then the project lags behind schedule and must be finished in a rush, which always means with extra costs.

Another reason is the change of plans, mostly for legal reasons. Many of them were related to public-private partnership agreements or to capacity changes to reduce the capacities (ATHOC, 2005b, 147). However, ATHOC President Gianna Angelopoulos-Daskalaki swiftly understood the importance that successful Olympic Games would have on the psyche of the Greek people. Her vision was that the success of the Olympic Games, the most high-profile and costly undertaking in Greece's recent history, would give the country a boost of confidence. This effect had not only a political aspect, but also a psychological parameter that had to reach the hearts and minds of people, both in a mental and a visual way. From the position of President of ATHOC, she understood that this could be achieved by building illustrious and impressive sports venues that would capture the spectator's eye in the short-term and still be there after the Olympic Games to remind the Greek people of the triumphant Athens 2004 Olympic Games. To this end, Angelopoulos-Daskalaki was instrumental in the decision of the Greek state to incorporate design excellence and signature architecture for the renovation of the main stadium (Pollalis 2006, 
4). Thus, star architect Calatrava signed the contract in October 2001 for a direct commission for the design of works at the OAKA, so that the Games would have a highly aesthetic dimension and the "signature" of an international architect (Pollalis 2006, 5). All the costs for such undertaking could certainly not have been included in the initial budget. In a press conference, Minister Venizelos revealed that the total cost of the aesthetic unification and functional improvements of the OAKA complex would be EUR $235 \mathrm{~m}$, with the aesthetic unification alone being EUR $126 \mathrm{~m}$ (Pollalis 2006, 9). Alm $(2012,105)$ puts the costs at USD $373 \mathrm{~m}$, which is all around the same dimension.

This is a good example of late planning. The Olympic Stadium roof was planned only in 2001 (t-3), the contract was signed at the end of 2002, and construction carried out from May 2003 to June 2004.

The last, but not least, important factor that caused cost overruns was the change in security in the aftermath of 9/11. It increased from roughly EUR 400m to EUR 1,100m after 9/11 (Cartalis 2015; Panagiotopoulou 2014, 177).

\section{$4.4 \quad$ Turin 2006}

According to law, two specific authorities were established with the aim of controlling the programme: the Torino Organising Committee (TOROC), a private foundation that was responsible for organising the Games, and Agenzia Torino 2006, a public body that was in charge of the implementation of the Olympic Programme (Bottero, Sacerdotti \& Mauro 2012, 204).

The permanent infrastructure that had to be delivered for the 2006 Olympic Games was managed by Agenzia Torino 2006, which was a public body with the dual function of acting as general contractor for all the planned works and which bore responsibility for their timely completion. The works activities were subdivided into different categories, according to their role in the event and to their financial support. The major aim of these "connected works" was a general redevelopment of the "Olympic territories" that made it possible to use the Games as a unique opportunity for developing and promoting tourism, even long after the mega event. According to this aim, several lines of intervention were identified. They encompassed the development of the winter tourist areas, road infrastructure, sewer systems, aqueducts, sanitary systems, and so forth. The cost of the "connected" public works totalled USD $429 \mathrm{~m}$, of which USD $273 \mathrm{~m}$ was financed by the government under Law 285/00 (Bondonio \& Campaniello 2006, 3). 
Moreover, the Piedmont Region, in an attempt to extend a positive spin-off from the Games to those greater regional areas not directly involved, adopted the "Regional Programme of Tourist and Sport Infrastructures - Piedmont 2006" (Art. 21 of the Regional Law 166/02). This initiative was called "Accompanying Public Works", to which USD $388 \mathrm{~m}$ was allocated. Of that figure, USD $202 \mathrm{~m}$ was financed by the central government and the remaining USD $186 \mathrm{~m}$ by the Piedmont Region from its own budget (Bondonio \& Campaniello 2006, 3).

Accompanying works were funded by Law No.166/2002 and had the aim of extending the beneficial effects of the Olympic investments to the whole region, to gain advantages for the entire Piedmont system.

Turin understood the opportunity that hosting the Olympic Games could offer the city and region, and the Organising Committee explicitly adopted a model to attract investments by maximising private funding and minimising public money funding (Bondonio \& Guala n. d.). The final total costs of investment amounted to USD 2,207m (at 2000 year prices), and according to Bondonio \& Guala (n. d., 6):

1. $65 \%$ of the total funding was financed by the "Olympic Law" No. 285/00,

2. whilst the remaining $35 \%$ was financed by:
a. Turin City Council 3.5\%,
b. the Region of Piedmont 2\%,
c. the Inter-departmental Committee for Economic Planning (CIPE) 3.5\%,
d. the National Public Corporation of Roads (ANAS) 5\%,
e. the Turin-Aosta Valley Highway Corporation (ATIVA) 5\%,
f. the Italian Corporation for the Frejus Tunnel (SITAF) 7\%,
g. the Public Regional Agency in charge of Environmental Prevention and Protection (ARPA) 1\%,
h. private investors $6 \%$, and by
i. Agenzia Torino 2006 2\%.

Here we see again that the wide spread of financing and involvement of different authorities make a full calculation of cost contributions difficult and, additionally, the various authorities may have had different aims regarding legacy.

According to Bondonio \& Guala (n. d., 6) an large amount of construction work, equally distributed between Turin and the Alpine locations, 36\% in the city, 64\% in the valleys, and the related infrastructure was carried out on time. It should be noted that the sporting facility costs did not exceed more than $30 \%$ of the total cost. 


\subsubsection{TOROC Revenue}

The revenues of the Organising Committee were not all provided in the details we needed. However, overall we can state a revenue overrun of $50 \%$ was reached one year before the Games.

Table 26 TOROC revenue evolution of estimates

\begin{tabular}{|c|c|c|c|c|c|c|c|c|}
\hline Categories & $\begin{array}{c}\text { Candidature File (t-8) } \\
(000 \text { EUR })\end{array}$ & $t-6$ & $t-5$ & $t-4$ & $t-3$ & $t-2$ & $t-1$ & final \\
\hline $\begin{array}{l}\text { IOC } \\
\text { Contribution }\end{array}$ & $\begin{array}{c}0 \% \\
(337,906)\end{array}$ & & & & & & $43 \%$ & \\
\hline Sponsorship & $\begin{array}{c}0 \% \\
(197,112)\end{array}$ & & & & & & $103 \%$ & \\
\hline Ticket Sales & $\begin{array}{c}0 \% \\
(42,238)\end{array}$ & & & & & & N/A & \\
\hline Licensing & $\begin{array}{c}0 \% \\
(32,852)\end{array}$ & & & & & & $192 \%$ & \\
\hline Lotteries & $\begin{array}{c}0 \% \\
(65,704)\end{array}$ & & & & & & N/A & \\
\hline Donations & & & & & & & N/A & \\
\hline $\begin{array}{l}\text { Disposal of } \\
\text { Assets }\end{array}$ & $\begin{array}{c}0 \% \\
(9,386)\end{array}$ & & & & & & $920 \%$ & \\
\hline Subsidies & $\begin{array}{c}0 \% \\
(56,318)\end{array}$ & & & & & & N/A & \\
\hline Other & $\begin{array}{c}0 \% \\
(23,466)\end{array}$ & & & & & & $204 \%$ & \\
\hline Total & $\begin{array}{c}0 \% \\
(764,981)\end{array}$ & & & & & & $50 \%$ & \\
\hline
\end{tabular}

Sources: Turin Bid Committee (1998); TOROC (2005)

The total of $50 \%$ contains all categories, as well as those not displayed here. The N/A data are included in "other" revenues. Based on the presentation TOROC gave to the IOC Executive Board, revenues were reduced to a few categories that were not congruent with those used in the Candidature File. The high amount in the disposal of assets category is due to a low and conservative assessment at the time of the application. As shown, we obtained data only from t- 1 and therefore cannot display the final real revenue overrun. In particular, the ticket sales and merchandise profits became visible only after the Games. Similar to Athens 2004, TOROC also benefited from the foreign exchange rate from USD to euro. 


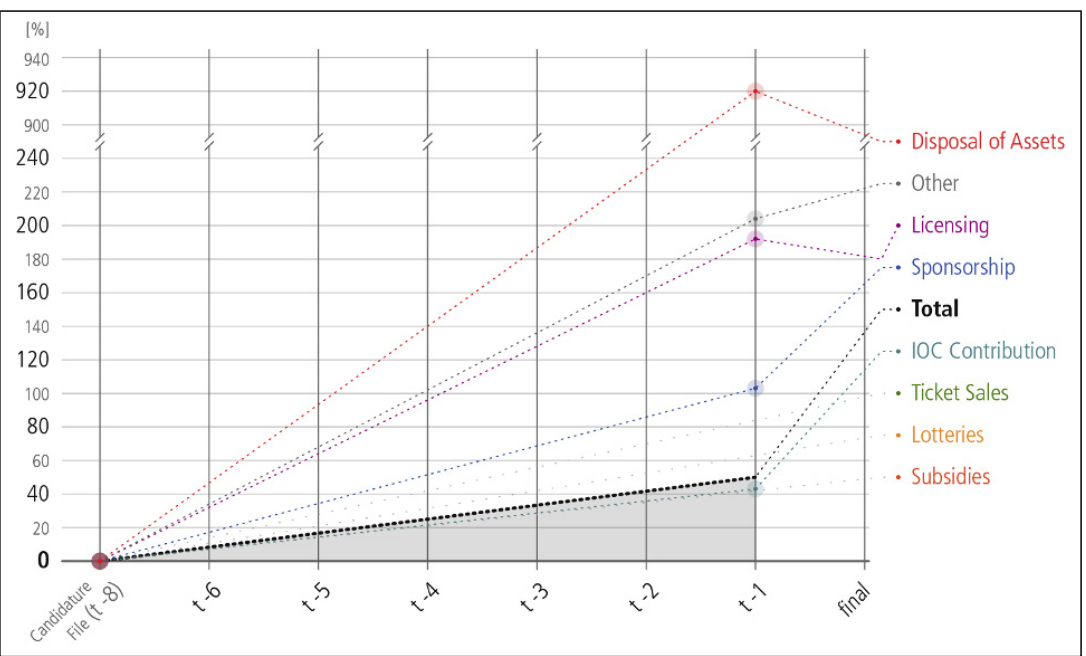

Fig. 22 TOROC revenue evolution of estimates

\subsubsection{TOROC Expenditure}

As the budget of TOROC was almost balanced at the end, it is no surprise that the expenditures were also higher than planned.

TOROC ended with total cost overrun of $58 \%$. The highest cost overrun of more than $270 \%$ was achieved by the technology and other categories. But there were also categories for which savings were made. For example, $81 \%$ in the venues area and $21 \%$ in the sector of administration \& coordination. For the period $t-1$, the others category was particularly high, as other categories such as services and administration \& coordination were assigned there. 
Table 27 TOROC expenditure evolution of estimates and final

\begin{tabular}{|c|c|c|c|c|c|c|c|c|}
\hline Categories & $\begin{array}{c}\text { Candidature } \\
\text { File (t-8) } \\
\text { (000 EUR) }\end{array}$ & $t-6$ & $t-5$ & $t-4$ & $t-3$ & $t-2$ & $t-1$ & $\begin{array}{c}\text { final } \\
\text { (000 EUR) }\end{array}$ \\
\hline Venues & $\begin{array}{c}0 \% \\
(281,588)\end{array}$ & & & & & & $-49 \%$ & $\begin{array}{c}-81 \% \\
(53,611)\end{array}$ \\
\hline Workforce & & & & & & & $0 \%$ & $\begin{array}{c}10 \% \\
(223,907)\end{array}$ \\
\hline Technology & $\begin{array}{c}0 \% \\
(103,249)\end{array}$ & & & & & & $145 \%$ & $\begin{array}{c}277 \% \\
(389,055)\end{array}$ \\
\hline Services & $\begin{array}{c}0 \% \\
(70,397)\end{array}$ & & & & & & & $\begin{array}{c}53 \% \\
(107,735)\end{array}$ \\
\hline $\begin{array}{l}\text { Marketing \& } \\
\text { Events }\end{array}$ & $\begin{array}{c}0 \% \\
(89,170)\end{array}$ & & & & & & $55 \%$ & $\begin{array}{c}79 \% \\
(159,786)\end{array}$ \\
\hline $\begin{array}{l}\text { Administration } \\
\text { \& Coordination }\end{array}$ & $\begin{array}{c}0 \% \\
(187,725)\end{array}$ & & & & & & & $\begin{array}{c}-21 \% \\
(148,747)\end{array}$ \\
\hline Other & $\begin{array}{c}0 \% \\
(32,852)\end{array}$ & & & & & & $1141 \%$ & $\begin{array}{c}279 \% \\
(124,640)\end{array}$ \\
\hline Total & $\begin{array}{c}0 \% \\
(764,981)\end{array}$ & & & & & & $50 \%$ & $\begin{array}{c}58 \% \\
(1,207,481)\end{array}$ \\
\hline
\end{tabular}

Sources: Turin Bid Committee (1998); TOROC (n. d., 2005)

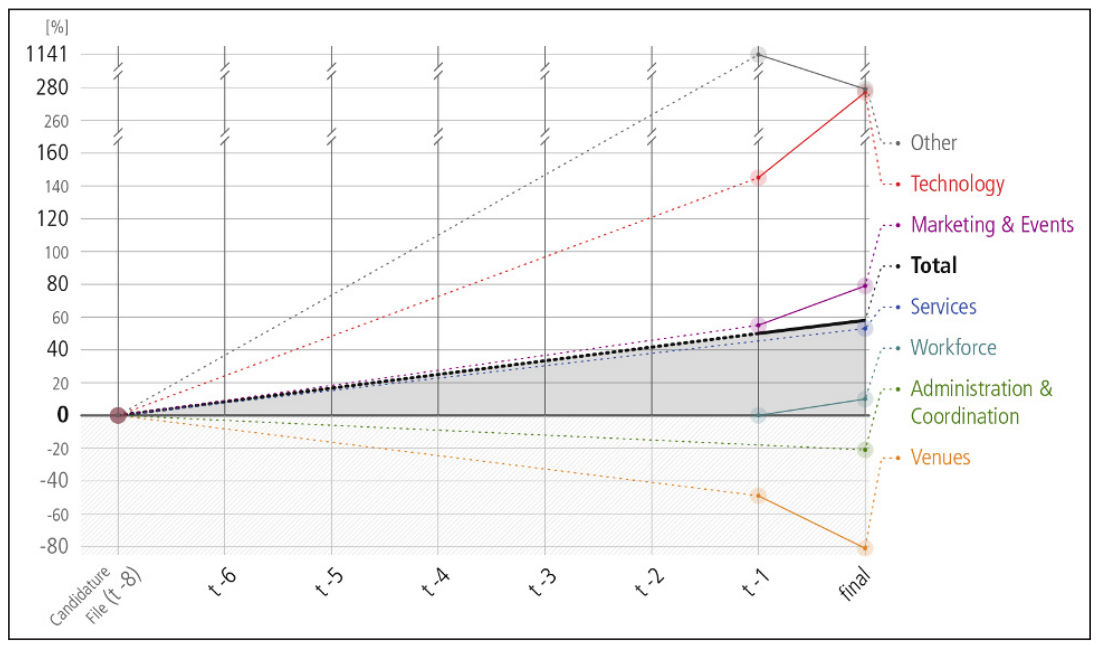

Fig. 23 TOROC expenditure evolution of estimates and final 


\subsubsection{Turin 2006 Non-OCOG Costs}

The cost overruns for our selected venues show a moderate $20 \%$.

Table 28 Turin 2006 non-OCOG cost evolution of estimates and final from public resources

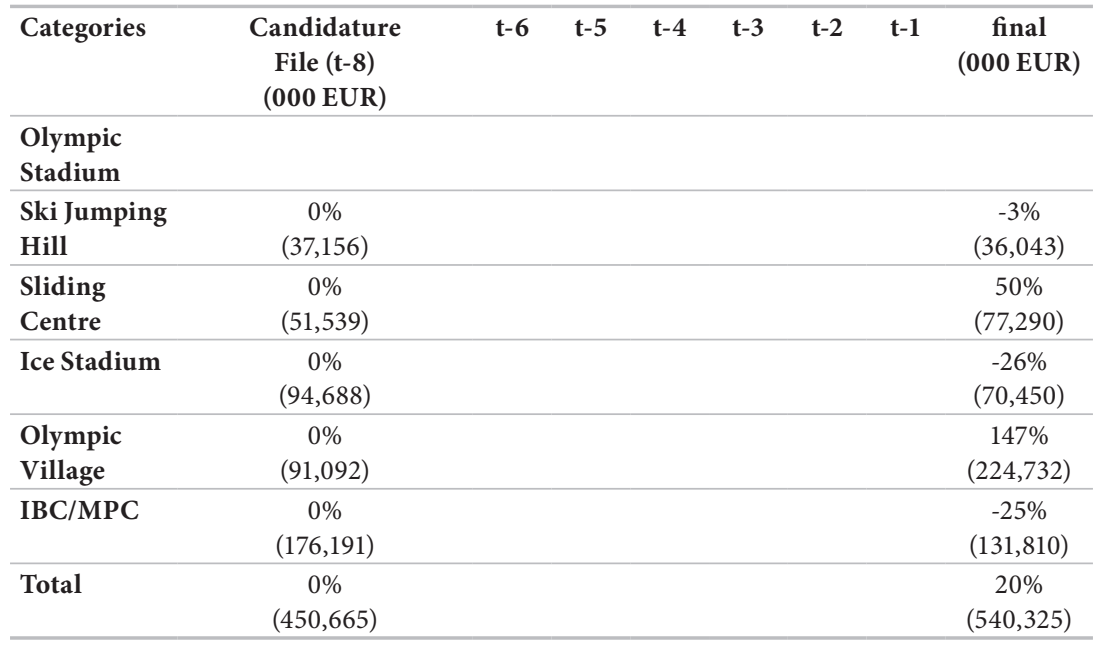

Sources: Bottero et al. (2012); Turin Bid Committee (1998)

Turin used an existing stadium to stage the Ceremonies, so there were no extra construction costs. The sliding centre and Olympic Village had cost overruns of $50 \%$ and $147 \%$ respectively. The remaining venues were built at a lower cost than planned, so the ski jumping hill cost 3\% less and the Ice Stadium and IBC/MPC both about $25 \%$ less. 


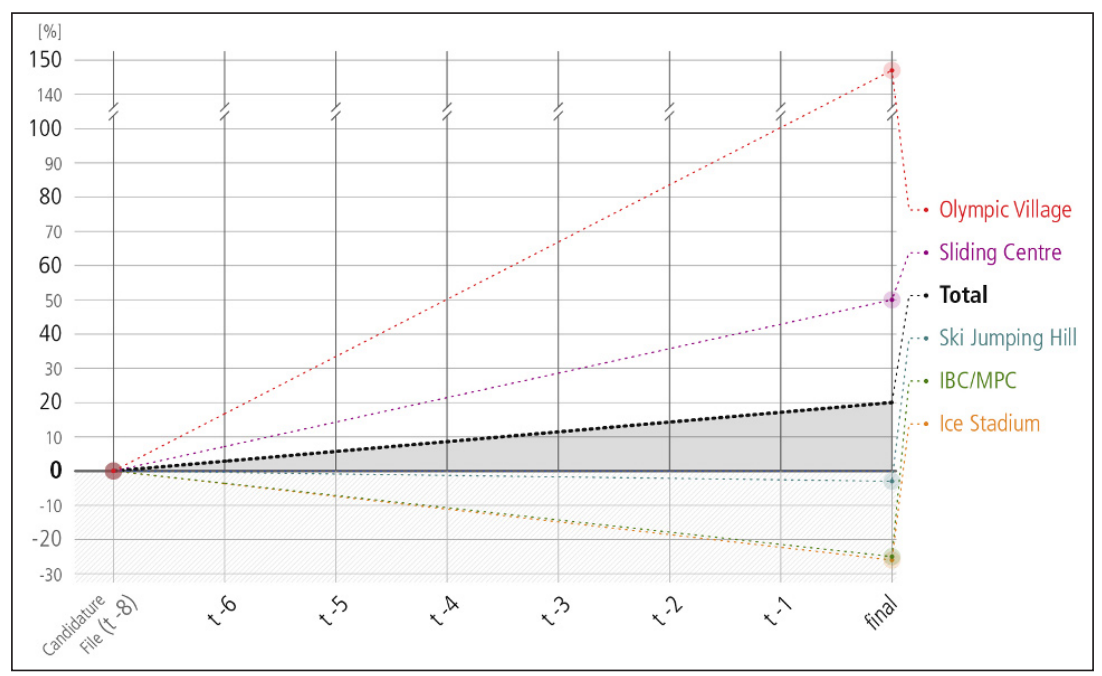

Fig. 24 Turin 2006 non-OCOG cost evolution of estimates and final from public resources

\subsection{Beijing 2008}

On 13 July 2001 Beijing was chosen to host the 2008 Olympic Games. The Government of the People's Republic of China promoted the Games and invested heavily in new facilities and transport systems. Thirty-seven venues were used to host the events, including 12 constructed specifically for use at the Games.

Overall the financial information for the Beijing Olympic Games is very limited.

\subsubsection{BOCOG Revenue}

From September 2005 to March 2009, the Audit Office of the Central Government carried out a follow-up audit of the financial revenues and expenditures of the Beijing Organising Committee for the Games of the XXIX Olympiad (BOCOG). The National Audit Report $(2009,1)$ states that "based on the sum of actual receipts and expenditures as of 15 March 2009, expected subsequent revenues, and expenditure accounts remaining to be settled, the revenues of BOCOG will reach 20.5bn yuan, 
an increase of $800 \mathrm{~m}$ yuan over the budgeted amount, and its expenditures will reach 19.343 bn yuan, slightly over budget. The surplus will thus exceed 1bn yuan".

Table 29 BOCOG revenue evolution of estimates and final

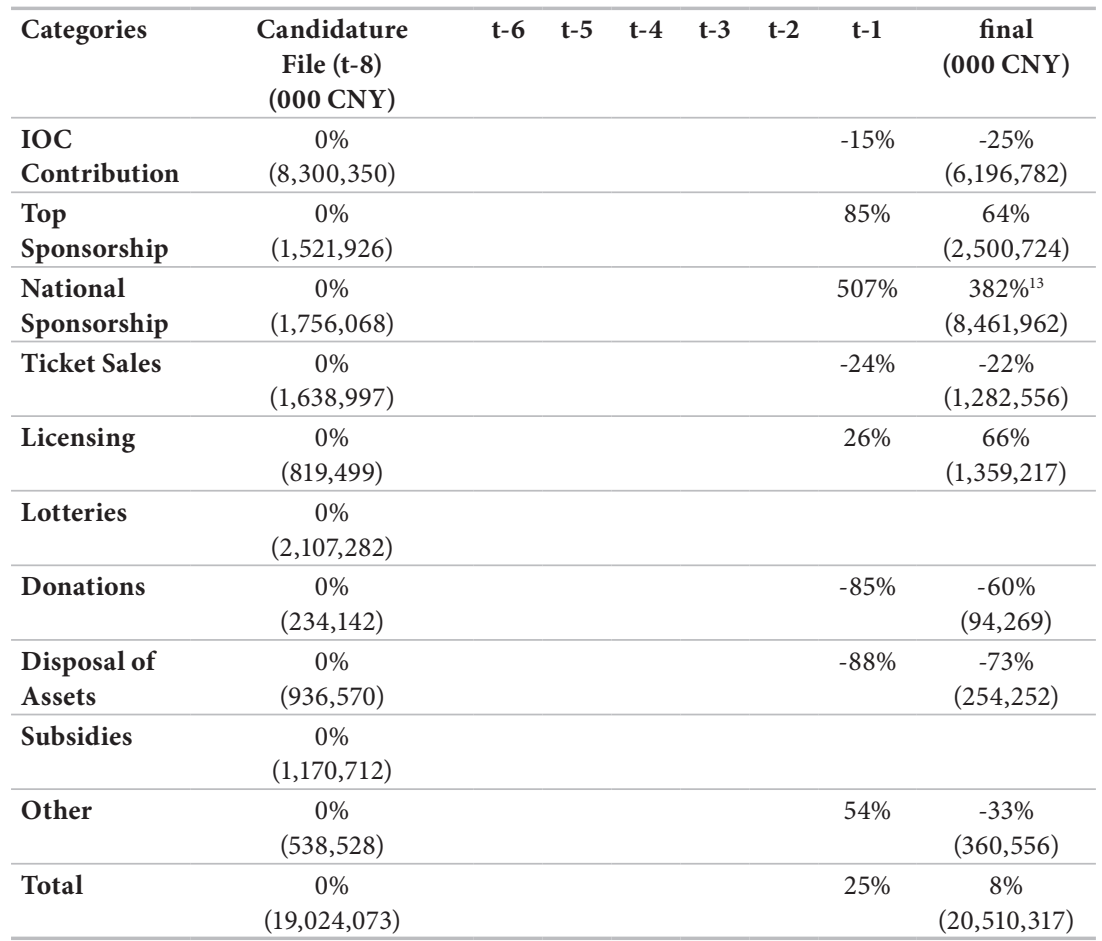

Sources: Beijing 2008 Olympic Games Bid Committee (2001); BOCOG (n. d., 2007)

The Olympic Games were very successful in selling merchandise. That can be seen in the immense increase of revenues to BOCOG, with $66 \%$ greater revenues than expected during the bidding. The Organising Committee also achieved 382\% more income through national sponsorship. The lower income from the IOC contribution

13 The final figure of national sponsorships revenues was reduced by the royalties paid to IOC. Therefore, the royalties also do not appear in the OCOG expenditures, which changed the final figure "other". 
can be explained by the fact that, until Beijing 2008, this IOC contribution was a percentage of the total TV revenue made. Many other categories received less than originally planned: ticket sales, donations, disposal of assets and other. In summary, BOCOG experienced $8 \%$ revenue overrun.

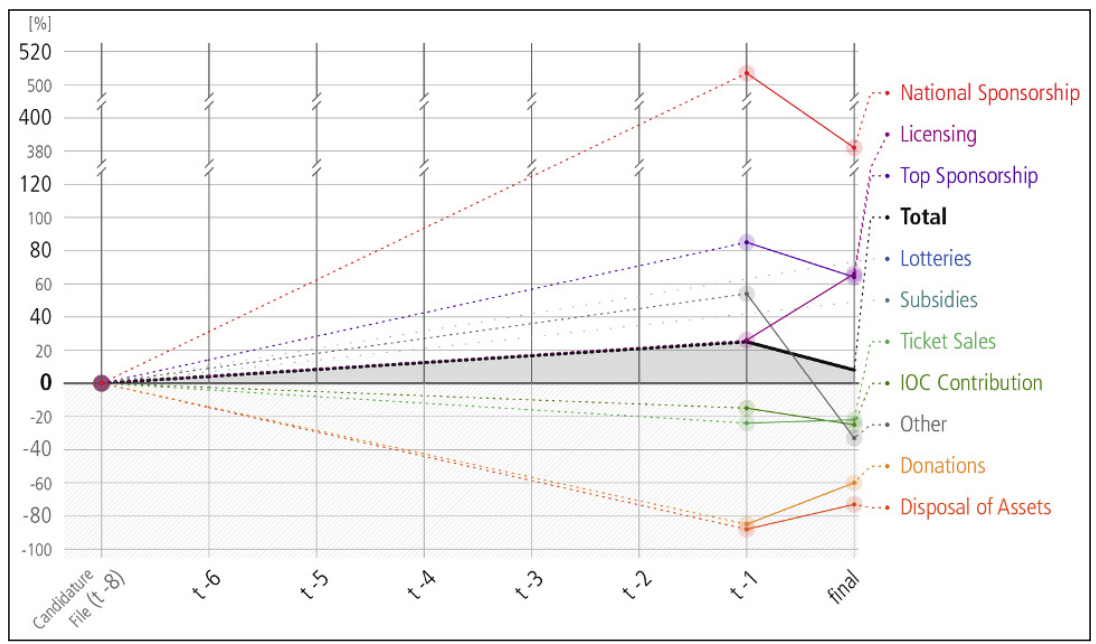

Fig. 25 BOCOG revenue evolution of estimates and final

\subsubsection{BOCOG Expenditure}

As we have seen before, it seems to be a pattern that, one year before the Games, the expenditures explode and then come back at Games year due to intensive saving.

Overall, the expenditures for BOCOG were managed very well. On the one hand, BOCOG saved between $15 \%$ and $54 \%$ in many categories, such as venues, workforce, technology and others. But other categories had cost overruns of between $9 \%$ and 45\%: services, marketing \& events, administration \& coordination. The high change in the "other" category is due to the royalties that were deducted directly from sponsorship revenues and therefore did no longer needed to be accounted in the final budget (see footnote 13). After all, all expenses resulted in a $4 \%$ cost overrun in the BOCOG budget. 
Table 30 BOCOG expenditure evolution of estimates and final

\begin{tabular}{|c|c|c|c|c|c|c|c|c|}
\hline Categories & $\begin{array}{c}\text { Candidature } \\
\text { File (t-8) } \\
(000 \mathrm{CNY})\end{array}$ & $t-6$ & $t-5$ & $t-4$ & $t-3$ & $t-2$ & $t-1$ & $\begin{array}{c}\text { final } \\
(000 \mathrm{CNY})\end{array}$ \\
\hline Venues & $\begin{array}{c}0 \% \\
(10,536,410)\end{array}$ & & & & & & $-78 \%$ & $\begin{array}{c}-54 \% \\
(4,866,966)\end{array}$ \\
\hline Workforce & & & & & & & $0 \%$ & $\begin{array}{c}-37 \% \\
(1,398,035)\end{array}$ \\
\hline Technology & & & & & & & $0 \%$ & $\begin{array}{c}-15 \% \\
(3,758,815)\end{array}$ \\
\hline Services & $\begin{array}{c}0 \% \\
(2,353,132)\end{array}$ & & & & & & $-14 \%$ & $\begin{array}{c}9 \% \\
(2,567,121)\end{array}$ \\
\hline $\begin{array}{l}\text { Marketing \& } \\
\text { Events }\end{array}$ & $\begin{array}{c}0 \% \\
(2,833,124)\end{array}$ & & & & & & $33 \%$ & $\begin{array}{c}45 \% \\
(4,101,156)\end{array}$ \\
\hline $\begin{array}{l}\text { Administration } \\
\text { \& Coordination }\end{array}$ & $\begin{array}{c}0 \% \\
(1,931,675)\end{array}$ & & & & & & $25 \%$ & $\begin{array}{c}19 \% \\
(2,293,439)\end{array}$ \\
\hline Other & $\begin{array}{c}0 \% \\
(1,182,419)\end{array}$ & & & & & & $445 \%$ & $\begin{array}{c}-50 \% \\
(585,333)\end{array}$ \\
\hline Total & $\begin{array}{c}0 \% \\
(18,836,760)\end{array}$ & & & & & & $25 \%$ & $\begin{array}{c}4 \% \\
(19,570,864)\end{array}$ \\
\hline
\end{tabular}

Sources: Beijing 2008 Olympic Games Bid Committee (2001), BOCOG (n. d., 2007)

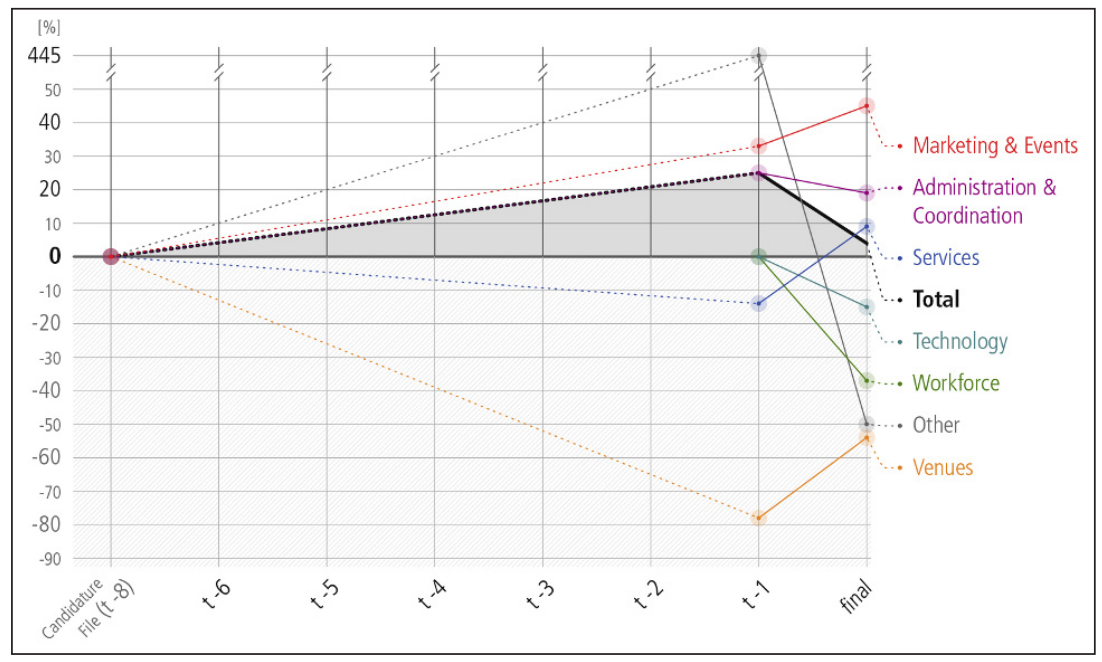

Fig. 26 BOCOG expenditure evolution of estimates and final 


\subsubsection{Beijing 2008 Non-OCOG Costs}

Costs for the venues were not available. Thus we cannot calculate cost overruns for Beijing 2008.

We tried hard to obtain information on Beijing's capital investments. However, we failed; and the Olympic scholars we contacted could not help and did not find any data on the Chinese internet. The only way left was using Western newspapers. Various costs for individual sports facilities, some of which fluctuated greatly, were very problematic, which is why they cannot be described as valid.

However, four years before the Games, the City of Beijing and BOCOG decided to reduce the investments into the Games by EUR 724m (FAZ 7.9.2004, 32). Several venues were shifted. One was to take the horse riding events to Hong Kong. The budget at that time was above USD 3,000m for the 18 new venues.

\subsection{Vancouver 2010}

The cost of the Games was shared by three levels of government, Olympic and Paralympic sponsors, and the Vancouver Organising Committee for the 2010 Olympic and Paralympic Winter Games (VANOC).

The City of Vancouver and VANOC were responsible for key aspects of the Games that took place in British Columbia (BC). This included the delivery of competition venues (PNE, Hillcrest, Trout Lake, Killarney and Britannia ice rinks), non-competition venues (such as the Olympic and Paralympic Village in South East False Creek, the Protocol Centre at Coal Harbour Community Centre and LiveCity sites), other key infrastructures and a number of 2010 Games programmes which supported Vancouver's' role as host city (British Columbia and Paralympic Winter Games Secretariat 2010,4). The three levels of government involved in the financing were:

1. Government of Canada

- provided 50\% of venue costs to VANOC (approx. CAD 290m)

- security

2. Province of British Columbia

- provided 50\% of venue costs to VANOC (approx. CAD 290m)

- contributed to federal security costs

3. City of Vancouver

- provided some operational support (traffic, live sites, etc.) 
- venue costs were primarily to expand the planned Olympic venues for civic use, such as a swimming pool.

The City of Vancouver was responsible for providing a number of different venues for the Olympic Games. This included the curling venue at the Vancouver Olympic Centre (or Hillcrest Community Centre), short-track/speed skating and figure skating venue at the Pacific Coliseum, and practice ice rinks at Trout Lake, Killarney, and Britannia. New facilities were built at Hillcrest and Trout Lake, while the remaining facilities were upgraded. Included in the Hillcrest cost estimates is CAD $35.8 \mathrm{~m}$ for the aquatic pool (built at the same time as the curling venue to take advantage of planning and construction synergies) and CAD $12.8 \mathrm{~m}$ for the postGames conversion of the facility to its final legacy of community centre, library and day-care facility (General Manager of Financial Services and General Manager of Olympic Operations 2010, 3).

\subsubsection{VANOC Revenue}

On 2 July 2003, the city of Vancouver was awarded the Olympic Winter Games 2010. VANOC was established as a not-for-profit company without share capital under Part II of the Canada Corporations Act on 30 September 2003, and registered extra-provincially under the BC Society Act.

The revenues of VANOC were as shown in the next table and figure.

Table 31 VANOC revenue evolution of estimates and final

\begin{tabular}{|c|c|c|c|c|c|c|c|c|}
\hline Categories & $\begin{array}{c}\text { Candidature } \\
\text { File (t-8) } \\
(000 \text { CAD) }\end{array}$ & $t-6$ & $t-5$ & $t-4$ & $t-3$ & $t-2$ & $t-1$ & $\begin{array}{c}\text { final } \\
\text { (000 CAD) }\end{array}$ \\
\hline $\begin{array}{l}\text { IOC } \\
\text { Contribution }\end{array}$ & $\begin{array}{c}0 \% \\
(666,145)\end{array}$ & & & & $-4 \%$ & $-33 \%$ & $-31 \%$ & $\begin{array}{c}-27 \% \\
(484,959)\end{array}$ \\
\hline $\begin{array}{l}\text { Top } \\
\text { Sponsorship }\end{array}$ & $\begin{array}{c}0 \% \\
(162,204)\end{array}$ & & & & $30 \%$ & $22 \%$ & $25 \%$ & $\begin{array}{c}7 \% \\
(173,948)\end{array}$ \\
\hline $\begin{array}{l}\text { National } \\
\text { Sponsorship }\end{array}$ & $\begin{array}{c}0 \% \\
(560,386)\end{array}$ & & & & $42 \%$ & $36 \%$ & $39 \%$ & $\begin{array}{c}30 \% \\
(730,989)\end{array}$ \\
\hline Ticket Sales & $\begin{array}{c}0 \% \\
(269,360)\end{array}$ & & & & $-10 \%$ & $-3 \%$ & $-1 \%$ & $\begin{array}{c}0.05 \% \\
(269,500)\end{array}$ \\
\hline Licensing & $\begin{array}{c}0 \% \\
(46,623)\end{array}$ & & & & $3 \%$ & $16 \%$ & $19 \%$ & $\begin{array}{c}25 \% \\
(58,179)\end{array}$ \\
\hline
\end{tabular}

Lotteries 


\begin{tabular}{|c|c|c|c|c|c|c|c|c|}
\hline Categories & $\begin{array}{c}\text { Candidature } \\
\text { File (t-8) } \\
(000 \text { CAD) }\end{array}$ & $t-6$ & $t-5$ & $t-4$ & $t-3$ & $t-2$ & $t-1$ & $\begin{array}{c}\text { final } \\
(000 \mathrm{CAD})\end{array}$ \\
\hline Donations & $\begin{array}{c}0 \% \\
(24,686)\end{array}$ & & & & & & & \\
\hline $\begin{array}{l}\text { Disposal of } \\
\text { Assets }\end{array}$ & $\begin{array}{c}0 \% \\
(12,344)\end{array}$ & & & & & & & \\
\hline Subsidies & $\begin{array}{c}0 \% \\
(49,372)\end{array}$ & & & & & & & $\begin{array}{c}280 \% \\
(187,796)\end{array}$ \\
\hline Other & $\begin{array}{c}0 \% \\
(69,432)\end{array}$ & & & & $127 \%$ & $302 \%$ & $311 \%$ & $\begin{array}{c}154 \% \\
(176,106)\end{array}$ \\
\hline Total & $\begin{array}{c}0 \% \\
(1,860,553)\end{array}$ & & & & $13 \%$ & $8 \%$ & $10 \%$ & $\begin{array}{c}12 \% \\
(2,081,477)\end{array}$ \\
\hline
\end{tabular}

Sources: Vancouver 2010 Candidate City (2002); VANOC (2007, 2008, 2009, 2014)

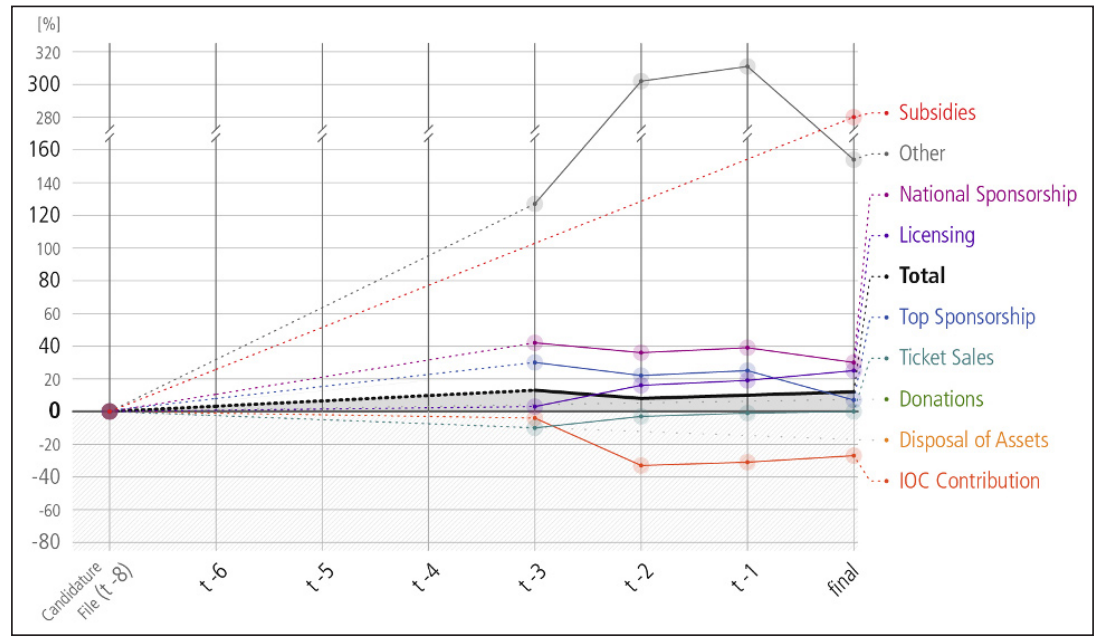

Fig. 27 VANOC revenue evolution of estimates and final

VANOC also had a revenue overrun of $12 \%$. The IOC contribution was $27 \%$ less than expected. It dropped dramatically because the exchange rate of the Canadian dollar dropped from bidding to staging the Games by $33 \%$. All other categories managed to receive a revenue overrun. The sale of tickets was well planned, with an increase of only $0.05 \%$. In addition, the TOP sponsorship, national sponsorship and income 
through licensing products had a moderate revenue overrun. The subsidies and others categories earnt more than twice as much as previously stated. Subsidies of CAD $187.8 \mathrm{~m}$ were contributed by British Columbia and Canada for the Paralympic Games, opening ceremonies, torch relay and medical services (VANOC 2010a).

\subsubsection{VANOC Expenditure}

It is typical for Games organising committees for an excess or a deficiency to arise and fluctuate as the timing of the receipt of revenues and the payment of expenses are dependent on specific contracts and do not follow a regular business cycle. On a project-to-date basis, there was, for example, an excess of deferred operating revenues over deferred operating expenses of CAD 198.0m (VANOC 2009, 4).

Comparing the revenues and expenditures from VANOC at the end we found a break-even position where there was no excess or deficiency of operating revenues over operating expenses. This break-even position reflects that some of VANOC's revenues, namely the final portion of the IOC contribution, were recognised and received only as required to cover expenditures (VANOC 2010, 4). VANOC's overall cost projection was not consistent, which is why there were very large fluctuations in different categories, with some categories even having no content at the end, or they were decentralised in other categories. On the basis of this fact, the changes and final figures of VANOC's expenses should be considered with caution. In summary, there was a $12 \%$ cost overrun.

Table 32 VANOC expenditure evolution of estimates and final

\begin{tabular}{|c|c|c|c|c|c|c|c|c|}
\hline Categories & $\begin{array}{c}\text { Candidature } \\
\text { File (t-8) } \\
(000 \text { CAD) }\end{array}$ & $t-6$ & $t-5$ & $t-4$ & $t-3$ & $t-2$ & $t-1$ & $\begin{array}{c}\text { final } \\
(000 \mathrm{CAD})\end{array}$ \\
\hline Venues & $\begin{array}{c}0 \% \\
(389,450)\end{array}$ & & & & & $-21 \%$ & & \\
\hline Workforce & $\begin{array}{c}0 \% \\
(285,467)\end{array}$ & & & & & $-60 \%$ & & \\
\hline Technology & $\begin{array}{c}0 \% \\
(341,057)\end{array}$ & & & & $22 \%$ & $13 \%$ & $18 \%$ & $\begin{array}{c}33 \% \\
(452,425)\end{array}$ \\
\hline Services & $\begin{array}{c}0 \% \\
(136,502)\end{array}$ & & & & & $117 \%$ & & \\
\hline $\begin{array}{l}\text { Marketing \& } \\
\text { Events }\end{array}$ & $\begin{array}{c}0 \% \\
(221,135)\end{array}$ & & & & $354 \%$ & $53 \%$ & $381 \%$ & $\begin{array}{c}437 \% \\
(1,186,514)\end{array}$ \\
\hline
\end{tabular}




\begin{tabular}{|c|c|c|c|c|c|c|c|c|}
\hline Categories & $\begin{array}{c}\text { Candidature } \\
\text { File (t-8) } \\
(000 \text { CAD) }\end{array}$ & $t-6$ & $t-5$ & $t-4$ & $t-3$ & $t-2$ & $t-1$ & $\begin{array}{c}\text { final } \\
(000 \mathrm{CAD})\end{array}$ \\
\hline $\begin{array}{l}\text { Administration } \\
\text { \& Coordination }\end{array}$ & $\begin{array}{c}0 \% \\
(175,130)\end{array}$ & & & & $-30 \%$ & $32 \%$ & $-26 \%$ & $\begin{array}{c}-34 \% \\
(115,799)\end{array}$ \\
\hline Other & $\begin{array}{c}0 \% \\
(311,812)\end{array}$ & & & & $77 \%$ & $6 \%$ & $45 \%$ & $\begin{array}{c}5 \% \\
(326,789)\end{array}$ \\
\hline Total & $\begin{array}{c}0 \% \\
(1,860,553)\end{array}$ & & & & $13 \%$ & $8 \%$ & $10 \%$ & $\begin{array}{c}12 \% \\
(2,081,527)\end{array}$ \\
\hline
\end{tabular}

Sources: Vancouver 2010 Candidate City (2002); VANOC (2007, 2008, 2009, 2014)

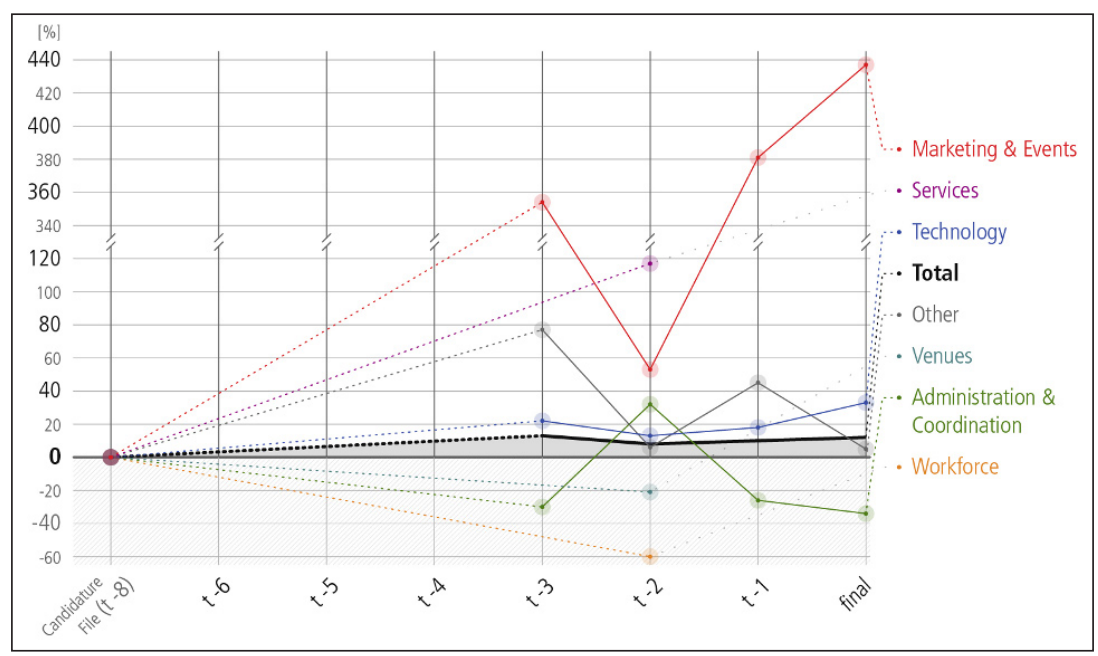

Fig. 28 VANOC expenditure evolution of estimates and final

\subsubsection{Vancouver 2010 Non-OCOG Costs}

The government of B C made significant contributions to the 2010 Winter Games. The total construction contribution of $\mathrm{BC}$ and the government of Canada was around CAD 580m for the venues. 
Table 33 Vancouver 2010 non-OCOG cost evolution of estimates and final from public resources

\begin{tabular}{|c|c|c|c|c|c|c|c|}
\hline Categories & $\begin{array}{c}\text { Candidature } \\
\text { File (t-8) } \\
(000 \text { CAD) }\end{array}$ & $t-6$ & $t-5$ & $t-4$ & $t-3$ & $t-2$ & $\begin{array}{c}\text { final } \\
(000 \mathrm{CAD})\end{array}$ \\
\hline $\begin{array}{l}\text { Olympic } \\
\text { Stadium }\end{array}$ & & $0 \%$ & $16 \%$ & $44 \%$ & & & $\begin{array}{c}323 \% \\
(12,094)\end{array}$ \\
\hline $\begin{array}{l}\text { Ski Jumping } \\
\text { Hill }\end{array}$ & $\begin{array}{c}0 \% \\
(124,944)\end{array}$ & $-7 \%$ & $-1 \%$ & $0 \%$ & $0 \%$ & & $\begin{array}{c}-2 \% \\
(122,467)\end{array}$ \\
\hline $\begin{array}{l}\text { Sliding } \\
\text { Centre }\end{array}$ & $\begin{array}{c}0 \% \\
(67,888)\end{array}$ & $-7 \%$ & $31 \%$ & $59 \%$ & $62 \%$ & & $\begin{array}{c}55 \% \\
(104,928)\end{array}$ \\
\hline Ice Stadium & $\begin{array}{c}0 \% \\
(50,404)\end{array}$ & $-19 \%$ & $-17 \%$ & $-19 \%$ & $-20 \%$ & & $\begin{array}{c}-24 \% \\
(38,216)\end{array}$ \\
\hline $\begin{array}{l}\text { Olympic } \\
\text { Village }^{44}\end{array}$ & $\begin{array}{c}0 \% \\
(327,468)\end{array}$ & & $14 \%$ & $13 \%$ & $12 \%$ & & $\begin{array}{c}12 \% \\
(367,300)\end{array}$ \\
\hline IBC/MPC & $\begin{array}{c}0 \% \\
(18,514)\end{array}$ & $-7 \%$ & & $-82 \%$ & & & N/A \\
\hline Total $^{15}$ & $\begin{array}{c}0 \% \\
(570,704)\end{array}$ & $-8 \%$ & $-11 \%$ & $-14 \%$ & $12 \%$ & & $\begin{array}{c}13 \% \\
(645,005)\end{array}$ \\
\hline
\end{tabular}

Sources: British Columbia Olympic and Paralympic Winter Games Secretariat (2004); Partnerships British Columbia (2007); Vancouver 2010 Candidate City (2002); VANOC (2007, 2010a, b)

Almost all buildings were financed exclusively by British Columbia and Canada. The only exception was the Olympic Village, which was largely funded by the City of Vancouver (VANOC, 2010b). The costs for the renovation of the Olympic Stadium were exceeded by $323 \%$, although it should be noted that no costs were planned for this at the time of the Candidature File, as the stadium already existed. The sliding centre exceeded $55 \%$ of its original cost estimate. Furthermore, the Olympic Village was $12 \%$ more expensive. In contrast, the construction of the Ski Jumping Hill (-2\%) and the Ice Stadium (-24\%) was below the estimates. All in all, we get a total cost overrun of $13 \%$ for Vancouver.

14 Vancouver Olympic Village and Whistler Olympic and Paralympic Village are accounted for in this category.

$15 \mathrm{IBC} / \mathrm{MPC}$ is not counted in the total amount since the final costs were not available. 


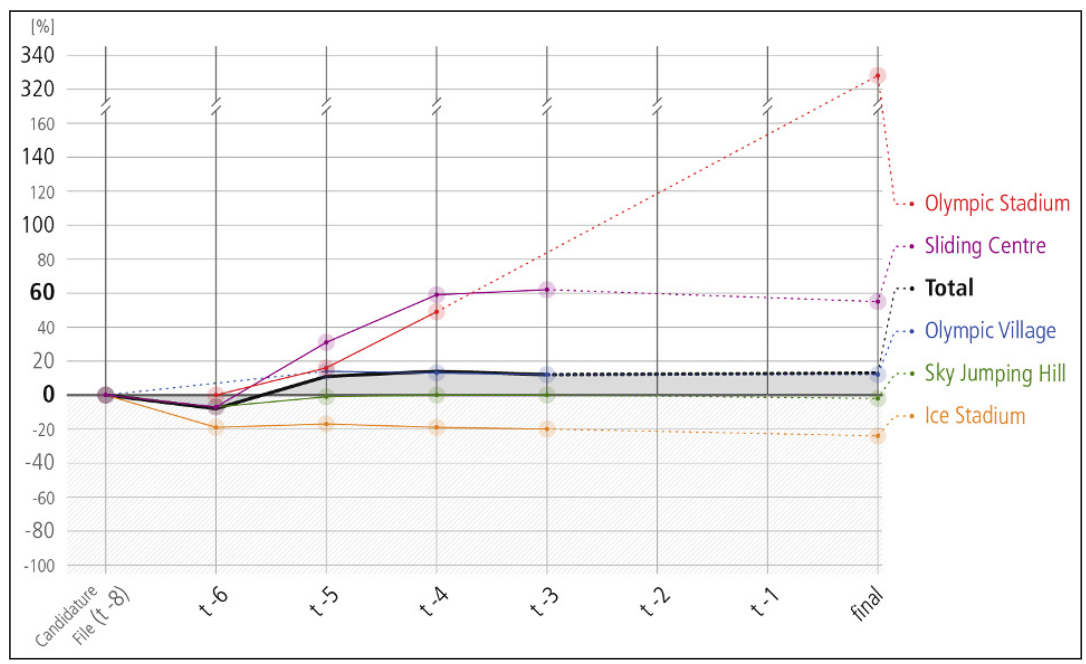

Fig. 29 Vancouver 2010 non-OCOG cost evolution of estimates and final from public resources

\subsection{London 2012}

Before a bid was decided, in May 2002, Arup (jointly commissioned by the Department for Culture, Media and Sport (DCMS), the Greater London Authority and the British Olympic Association) reported on the costs and benefits of bidding for the Games. Then, in early 2003, PricewaterhouseCoopers (commissioned by DCMS) produced a probability assessment of the risks and uncertainties involved in a bid to host the Games. The government announced in May 2003 its support for a London bid for the 2012 Games, and the government and the Mayor of London agreed a public sector funding package of GBP 2,375m to meet the costs of the Games.

Government funding for the 2012 Olympic and Paralympic programme, excluding security, was held by the DCMS already in June 2003. That was the host department of the London 2012 Olympic and Paralympic Games. The DCMS aimed to improve the quality of life for all through cultural and sporting activities, to support the pursuit of excellence and to champion the tourism, creative and leisure industries. The Government Olympic Executive was set up within the DCMS to ensure the Games were delivered on time and on budget and that they benefited the whole of the UK. This included overseeing the entire London 2012 project, identifying 
and solving problems, delivering the public sector effort and being accountable to Parliament and to the public (DCMS 2012a, 23).

The Greater London Authority and the Olympic Lottery Distributor also contributed a lot to the Games. Security funding continued to be provided primarily by the Home Office.

The Olympic Delivery Authority (ODA) was established in April 2006 by the London Olympic and Paralympic Games Act 2006, and was responsible for building the permanent venues and infrastructure needed for the Games (ODA 2015, 1). The ODA was a non-departmental public body whose board was appointed by the Minister for the Olympic and Paralympic Games (in consultation with the Mayor of London) and reported to the Government Olympic Executive. The ODA was the primary recipient of support from the public sector funding package, which comprised funding from the government, the lottery and the Mayor of London (DCMS 2012a, 23).

The following figure shows the various authorities/organisations that were involved in the staging of the Olympic Games.

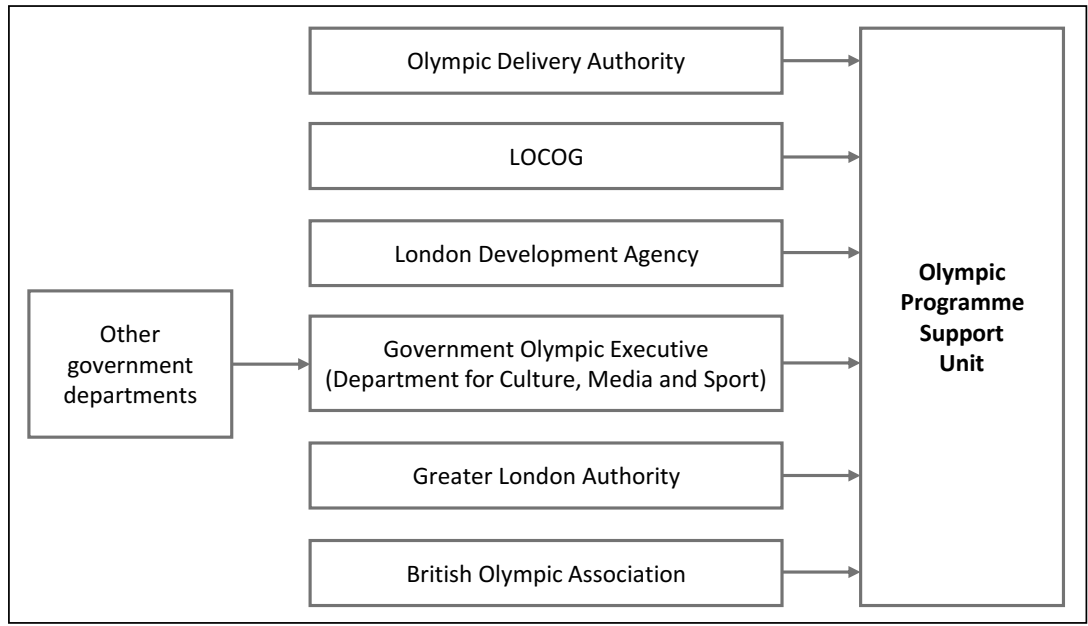

Fig. 30 Authorities/Organisations involved in delivering and controlling the Olympic Games 2012

Source: National Audit Office (2007a, 23) 
As a reminder, at the time the bid was submitted, the estimated cost to the public and private sector was around GBP 5bn. The GBP 2,375m public sector funding package was intended to cover the GBP 2,992m core Olympic costs, towards which GBP $738 \mathrm{~m}$ of private sector funding was also expected. Additionally, there was GBP $1,044 \mathrm{~m}$ exchequer funding towards the infrastructure on the site of the Olympic Park (National Audit Office 2007b, 28).

Overall the public funding of the Games was GBP 9,298m (National Audit Office 2012 , 22), including all work on infrastructure. However, in the post-Games period, the revenues from the sale of land in the Olympic Park or the sale of the Olympic Village reduced this funding severely. It was estimated that more than GBP $1,340 \mathrm{~m}$ would flow back to the government, the National Lottery and the City of London (DCMS 2012b, 16). In 2012, it was expected that, without further cost pressures emerging, there would be a GBP $377 \mathrm{~m}$ underspend against the Funding Package (National Audit Office 2012, 22), which meant the total costs were GBP 8,921m. Against this, the anticipated final cost for the ODA programme as at November 2014, including residual liabilities to be discharged by the ODA statutory successor body, DCMS, was GBP 6,739m (ODA 2015, 8). Savings against the original baseline budget derived primarily from value engineering changes, effective risk management, procurement, lower inflation, efficient delivery, prompt commercial close-out and VAT recovery.

\section{Fig. 31}

Funding for the Olympic and Paralympic Games in London 2012

Source: DCMS (2012b, 16)

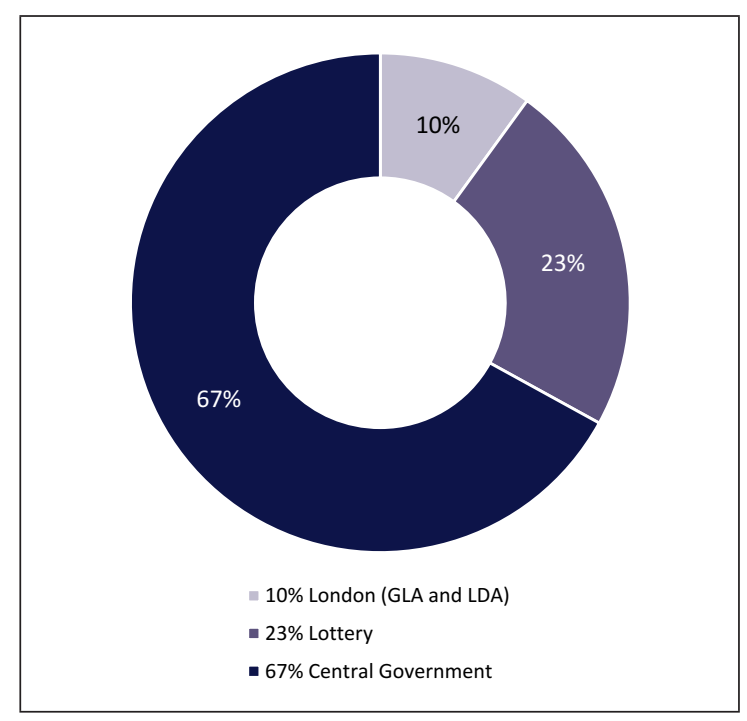


Working against cost overruns, the ODA was able to save further against the original budget by GBP $1,032 \mathrm{~m}$. The latest savings ODA was able to achieve were largely from the efficient delivery of Games-time transport operations (such as ORN and rail services), corporate security services, and venues (DCMS 2012b, 11).

The overall costs shown here include venue security costs of GBP $514 \mathrm{~m}$ for this Games (National Audit Office 2012, 23). The anticipated final cost (September 2012) of policing and providing security outside the venues was GBP 455m (National Audit Office 2012, 23).

The London Organising Committee of the Olympic Games and Paralympic Games (LOCOG) and the Olympic Delivery Authority wound up in 2013 and 2014 respectively.

\subsubsection{LOCOG Revenue}

LOCOG was responsible for the overall staging of the 2012 Games. LOCOG raised its own income through a variety of sources, including ticket sales, sponsorship, merchandising and the IOC (broadcasting revenue, TOP sponsorship programme). It also received a small percentage of its income from the government towards the cost of the Paralympic Games. It was a private company limited by guarantee established by a joint venture agreement between three stakeholders:

1. Secretary of State for Culture, Olympics, Media and Sport,

2. Mayor of London,

3. British Olympic Association.

The income generated through these various sources were assigned to staging the Games only. LOCOG did not fund the capital costs of venues or other permanent infrastructures. 
Table 34 LOCOG revenue evolution of estimates and final

\begin{tabular}{|c|c|c|c|c|c|c|c|c|}
\hline Categories & $\begin{array}{c}\text { Candidature } \\
\text { File (t-8) } \\
(000 \text { GBP) }\end{array}$ & $t-6$ & $t-5^{16}$ & $t-4^{16}$ & $t-3^{16}$ & $t-2$ & $t-1$ & $\begin{array}{c}\text { final } \\
\text { (000 GBP) }\end{array}$ \\
\hline $\begin{array}{l}\text { IOC } \\
\text { Contribution }\end{array}$ & $\begin{array}{c}0 \% \\
(390,514)\end{array}$ & & $-5 \%$ & $-6 \%$ & $-5 \%$ & & $-2 \%$ & $\begin{array}{c}-2 \% \\
(381,600)\end{array}$ \\
\hline $\begin{array}{l}\text { Top Sponsor- } \\
\text { ship }\end{array}$ & $\begin{array}{c}0 \% \\
(195,257)\end{array}$ & & $-7 \%$ & $-5 \%$ & $-5 \%$ & & $8 \%$ & $\begin{array}{c}19 \% \\
(232,200)\end{array}$ \\
\hline $\begin{array}{l}\text { National } \\
\text { Sponsorship }\end{array}$ & $\begin{array}{c}0 \% \\
(471,871)\end{array}$ & & $36 \%$ & $46 \%$ & $47 \%$ & & $49 \%$ & $\begin{array}{c}55 \% \\
(731,100)\end{array}$ \\
\hline Ticket Sales & $\begin{array}{c}0 \% \\
(322,825)\end{array}$ & & $15 \%$ & $14 \%$ & $27 \%$ & & $91 \%$ & $\begin{array}{c}104 \% \\
(657,100)\end{array}$ \\
\hline Licensing & $\begin{array}{c}0 \% \\
(59,879)\end{array}$ & & $11 \%$ & $18 \%$ & $19 \%$ & & $60 \%$ & $\begin{array}{c}35 \% \\
(80,900)\end{array}$ \\
\hline \multicolumn{9}{|l|}{ Lotteries } \\
\hline \multicolumn{9}{|l|}{ Donations } \\
\hline $\begin{array}{l}\text { Disposal of } \\
\text { Assets }\end{array}$ & $\begin{array}{c}0 \% \\
(23,431)\end{array}$ & & $19 \%$ & $18 \%$ & $-35 \%$ & & $1 \%$ & $\begin{array}{c}-55 \% \\
(10,500)\end{array}$ \\
\hline Subsidies & $\begin{array}{c}0 \% \\
(46,862)\end{array}$ & & $48 \%$ & $47 \%$ & $48 \%$ & & $106 \%$ & $\begin{array}{c}143 \% \\
(114,100)\end{array}$ \\
\hline Other & $\begin{array}{c}0 \% \\
(91,771)\end{array}$ & & $214 \%$ & $181 \%$ & $21 \%$ & & $177 \%$ & $\begin{array}{c}121 \% \\
(202,900)\end{array}$ \\
\hline Total & $\begin{array}{c}0 \% \\
(1,602,409)\end{array}$ & & $26 \%$ & $27 \%$ & $20 \%$ & & $48 \%$ & $\begin{array}{c}50 \% \\
(2,410,400)\end{array}$ \\
\hline
\end{tabular}

Sources: IOC data; LOCOG (2008, 2009, 2012); London 2012 Candidate City (2004)

The IOC contribution to the 2012 Games came from income generated, and from projected income - to be raised by the Olympic Movement - primarily from the sale of television and related broadcast image rights. Here, the minus $2 \%$ was caused by inflation rate adjustments. The TOP sponsorship contain included money from the Worldwide Partners' scheme. However, nearly $40 \%$ of the sponsorship money came from local and national sponsorship. These revenues came from the sale of marketing rights, and were paid for in return for exclusive marketing communications and advertising rights in relation to the 2012 Games (and within the 'quadrennial period' that included the Vancouver 2010 Winter Games) (UEL 2013, 115).

The table does not show revenues from lotteries and donations. The latter were included in "others". Lottery funding was added to help fund the infrastructure

16 LOCOG had used nominal numbers in its cost and revenue projection, so we downgraded a projected inflation of $2 \%$ per year and inflated with the actual GDP-deflator. 
and other programmes, such as the support of elite athletes and coaches, but not LOCOG (National Audit Office 2007b, 18).

The partly high revenue overruns can be explained by conservative revenue estimates. Experience with the Millennium Dome, where the income generated fell well short of the amounts forecast, served as a lesson for a number of LOCOG's planned revenue sources (National Audit Office 2007a, 17). In summary, LOCOG had a cost overrun of $50 \%$.

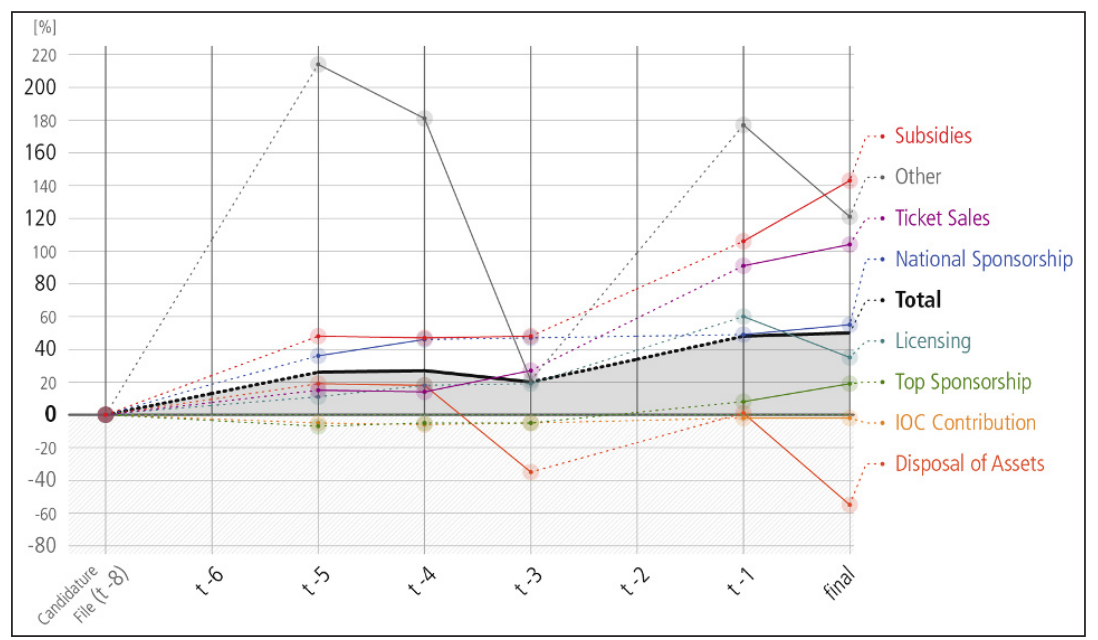

Fig. 32 LOCOG revenue evolution of estimates and final

\subsubsection{LOCOG Expenditure}

Funding made available to LOCOG had increased by GBP $41 \mathrm{~m}$ in the period between May and September 2012. Having taken over responsibility for the Olympic Park earlier than originally planned, in January 2012, following the completion of all main venues the previous July 2012, LOCOG was better placed to undertake a range of work, and thus the ODA did less (DCMS 2012b, 11). This explains the expenditure overruns of LOCOG for "venues" (see next table). The increase was also caused by underestimating the overlay costs.

The costs for workforce fluctuated a lot three to five years before the Games. Marketing exploded a year before the Games and finally left a 78\% expenditure overrun. The total expenditure overrun of LOCOG was at $48 \%$, which was - as 
usual - covered by the revenue overruns as can be seen in the table above. The September 2012 accounts showed an operating loss of GBP 53m, though there were deferred revenues of GBP $75 \mathrm{~m}$, which turned out a profit position later. LOCOG was at that time still facing expenditures in closing all its contracts and closing down the organisation (UEL 2013, 116). All in all, the cost overrun of the Organising Committee in London was about $48 \%$.

Table 35 LOCOG expenditure evolution of estimates and final

\begin{tabular}{|c|c|c|c|c|c|c|c|c|}
\hline Categories & $\begin{array}{c}\text { Candidature } \\
\text { File (t-8) } \\
(000 \text { GBP) }\end{array}$ & $t-6$ & $t-5^{17}$ & $t-4^{17}$ & $t-3^{17}$ & $t-2$ & $t-1$ & $\begin{array}{c}\text { final } \\
(000 \mathrm{GBP})\end{array}$ \\
\hline Venues & $\begin{array}{c}0 \% \\
(443,233)\end{array}$ & & $22 \%$ & $26 \%$ & $7 \%$ & & $45 \%$ & $\begin{array}{c}58 \% \\
(701,668)\end{array}$ \\
\hline Workforce & $\begin{array}{c}0 \% \\
(121,710)\end{array}$ & & $154 \%$ & $-49 \%$ & $248 \%$ & & $-16 \%$ & $\begin{array}{c}-14 \% \\
(104,362)\end{array}$ \\
\hline Technology & $\begin{array}{c}0 \% \\
(291,584)\end{array}$ & & $-5 \%$ & $30 \%$ & $57 \%$ & & $60 \%$ & $\begin{array}{c}72 \% \\
(501,888)\end{array}$ \\
\hline Services & $\begin{array}{c}0 \% \\
(178,986)\end{array}$ & & $24 \%$ & $20 \%$ & $10 \%$ & & $-30 \%$ & $\begin{array}{c}48 \% \\
(264,257)\end{array}$ \\
\hline $\begin{array}{l}\text { Marketing } \\
\text { \& Events }\end{array}$ & $\begin{array}{c}0 \% \\
(213,481)\end{array}$ & & $11 \%$ & $38 \%$ & $-6 \%$ & & $209 \%$ & $\begin{array}{c}78 \% \\
(380,077)\end{array}$ \\
\hline $\begin{array}{l}\text { Administration } \\
\text { \& Coordination }\end{array}$ & $\begin{array}{c}0 \% \\
(178,986)\end{array}$ & & $33 \%$ & $62 \%$ & $-54 \%$ & & $55 \%$ & $\begin{array}{c}70 \% \\
(303,820)\end{array}$ \\
\hline Other & $\begin{array}{c}0 \% \\
(174,430)\end{array}$ & & $11 \%$ & $37 \%$ & $10 \%$ & & $-41 \%$ & $\begin{array}{c}-34 \% \\
(114,572)\end{array}$ \\
\hline Total & $\begin{array}{c}0 \% \\
(1,602,409)\end{array}$ & & $26 \%$ & $27 \%$ & $26 \%$ & & $48 \%$ & $\begin{array}{c}48 \% \\
(2,370,644)\end{array}$ \\
\hline
\end{tabular}

Sources: LOCOG (2008, 2009 2012, 2013); London 2012 Candidate City (2004)

Two grants were made available to LOCOG immediately prior to the start of the Games: one for GBP 9.3m to cover the additional costs of venue preparation as a result of the extremely wet weather in the months leading up to the Games; and one for GBP $5 \mathrm{~m}$ to cover Games-time contingency requirements. LOCOG confirmed that it would not require these grants, as it had planned to be able to cover both the pre-Games expenditure and Games-time contingency expenditures by

17 LOCOG had used nominal numbers in its cost and revenue projection, so we downgraded a projected inflation of $2 \%$ per year and inflated with the actual GDP-deflator. 
its own budget (DCMS 2012b, 11). Here the weather conditions as a potential cost overrun is mentioned.

LOCOG forecast that its final costs would be covered by its income. LOCOG raised GBP $731 \mathrm{~m}$ in local and national sponsorship, hitting its upper sponsorship target during difficult economic conditions. Consistent with its guarantee to cover shortfalls in revenue, LOCOG's income included GBP 27m from the Public Sector Funding Package, which the government provided to enable LOCOG to move forward more confidently (National Audit Office 2012, 8).

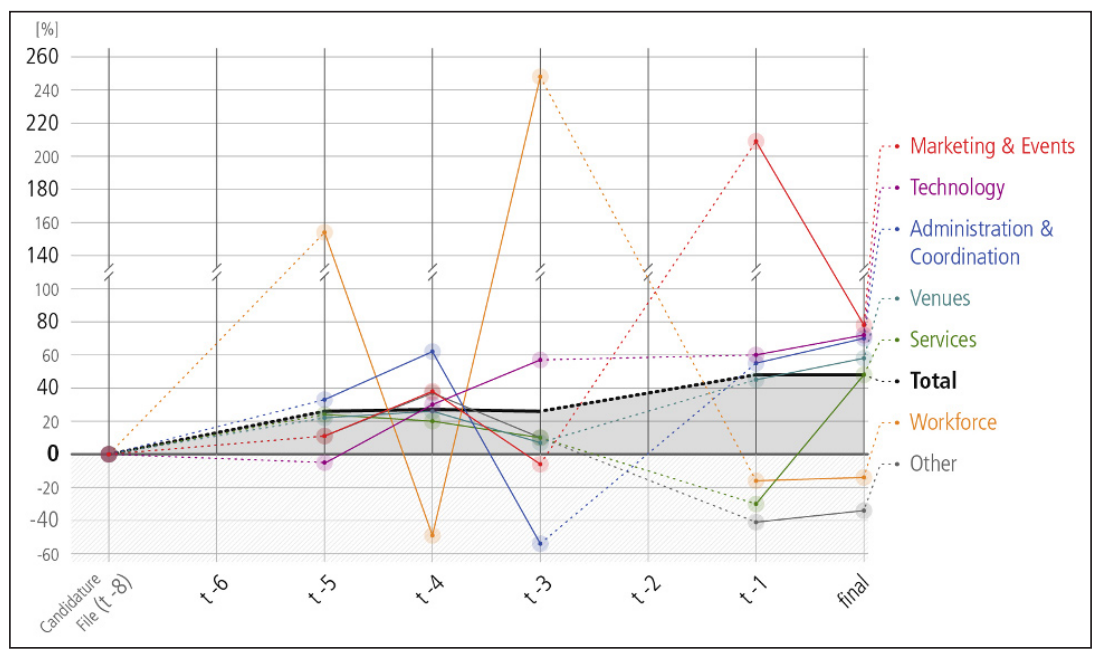

Fig. 33 LOCOG expenditure evolution of estimates and final

\subsubsection{London 2012 Non-OCOG Costs}

The National Audit Office $(2012,33)$ stated that, in its first report (February 2007), it highlighted the need for the budget to be clearly determined and effectively managed. After the Games were awarded to London in July 2005, a good deal of work was done to develop the cost estimates, but the ODA had to make decisions about individual projects without certainty of its overall budget and long-term funding. In March 2007, the Department announced a revised Public Sector Funding Package of GBP 9.3bn. This was more or less been stable until the delivery of the Games, even though at the end it was GBP 6,739m (ODA 2015, 8). However, to the public 
the immense cost increases became obvious and incited concerns between bidding in 2003 and 2007.

The cost overruns of our selected venues (basket) (Tab. 36) are shown in the next table. When looking at the cost development of the venues in London, it is noticeable that all venues became more expensive than originally planned. The swimming pool was three times as expensive as expected, as was the Velodrome, and the IBC/MPC cost more than twice as much. The construction of the Olympic Village had a rather moderate percentage increase in costs. In summary, the cost increase in the non-OCOG area can be estimated at $43 \%$.

Table 36 London 2012 non-OCOG evolution of estimates and final from public resources

\begin{tabular}{|c|c|c|c|c|c|c|c|c|}
\hline Categories & $\begin{array}{c}\text { Candidature } \\
\text { File (t-8) } \\
(000 \text { GBP) }\end{array}$ & $t-6$ & $t-5$ & $\mathrm{t}-4$ & $t-3$ & $t-2$ & $t-1$ & $\begin{array}{c}\text { final } \\
(000 \text { GBP })\end{array}$ \\
\hline $\begin{array}{l}\text { Olympic } \\
\text { Stadium }\end{array}$ & $\begin{array}{c}0 \% \\
(305,690)\end{array}$ & $67 \%$ & & & & $79 \%$ & & $\begin{array}{c}40 \% \\
(429,000)\end{array}$ \\
\hline $\begin{array}{l}\text { Swimming } \\
\text { Pool }\end{array}$ & $\begin{array}{c}0 \% \\
(79,479)\end{array}$ & $178 \%$ & & & & $242 \%$ & & $\begin{array}{c}216 \% \\
(251,000)\end{array}$ \\
\hline $\begin{array}{l}\text { Multipurpose } \\
\text { Hall }\end{array}$ & $\begin{array}{c}0 \% \\
(27,172)\end{array}$ & $120 \%$ & & & & & & $\begin{array}{c}47 \% \\
(40,000)\end{array}$ \\
\hline Velodrome & $\begin{array}{c}0 \% \\
(31,248)\end{array}$ & $138 \%$ & & & & $218 \%$ & & $\begin{array}{c}182 \% \\
(88,000)\end{array}$ \\
\hline $\begin{array}{l}\text { Olympic } \\
\text { Village }\end{array}$ & $\begin{array}{c}0 \% \\
(706,484)\end{array}$ & & & & & & & $\begin{array}{c}6 \% \\
(748,000)\end{array}$ \\
\hline IBC/MPC & $\begin{array}{c}0 \% \\
(146,052)\end{array}$ & $55 \%$ & & & & & & $\begin{array}{c}103 \% \\
(297,000)\end{array}$ \\
\hline Total & $\begin{array}{c}0 \% \\
(1,296,126)\end{array}$ & $85 \%$ & & & & $120 \%$ & & $\begin{array}{c}43 \% \\
(1,853,000)\end{array}$ \\
\hline
\end{tabular}

Sources: DCMS (2012a, b); House of Commons (2010); London 2012 Candidate City (2004)

The Olympic Village was partly financed by the private sector. That funding is not considered here and may have been probably lower if we had considered the private funding. In addition, when the deals with the private sector to fund the Olympic Village and Media Centre became problematic in 2007, the government funders enabled the ODA to continue the construction work in parallel with resolving how to fund the two projects (National Audit Office 2012, 30). This was needed to keep the programme on track and required a degree of pragmatism even though the activities did not progress in an ideal sequence. 


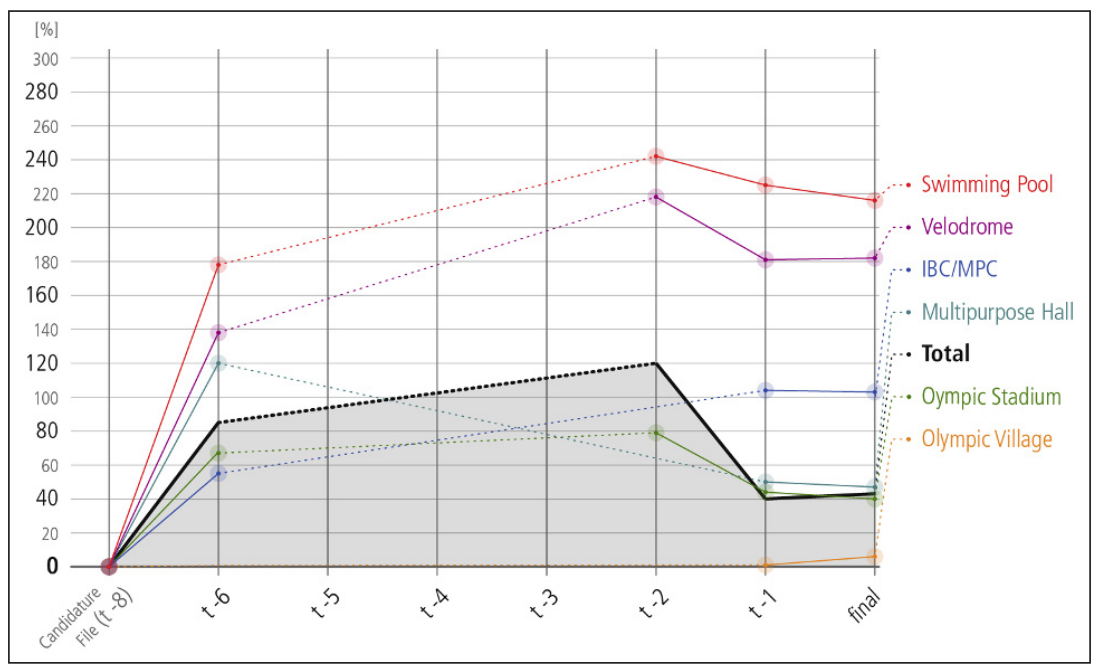

Fig. 34 London 2012 non-OCOG cost evolution of estimates and final from public resources

At the end of December 2006, the National Audit Office (2007a, 16) gave the following reasons for cost overruns and the need to develop new cost plans and budgets.

Contingency provision: The cost estimates in the Candidature File included a contingency provision to cover unanticipated costs on individual projects. This contingency was too low.

Tax: Treasury guidance stated that tax costs should be included in cost estimates. At the time of the bid, the tax status of the proposed ODA was undecided and the cost estimates in the Candidature File excluded provision for value added tax.

Security: $\quad$ The cost estimates at the time of the bid included GBP $190 \mathrm{~m}$ for security, including the cost of security at the Olympic venues. However, as stated above, the reality was that security was around GBP 514m (National Audit Office 2012, 23).

Private sector investment: At the time of the bid it was assumed that some Olympic infrastructure and regeneration costs would be met by private sector investment or financing of around GBP 
$750 \mathrm{~m}$, thereby reducing the cost of the Games to the public sector. However, in the light of advice following the bid, the Department concluded there was little prospect of securing significant private sector funding to deliver the Olympic Park in view of the tight timescale for delivering the Park and the lack of an identifiable revenue stream.

When analysing the bid budget of 2004 (non-OCOG and LOCOG) with a first serious budget from 2007, the following areas needed a major cost adjustment (National Audit Office 2007b, 16).

1. Venues (including legacy conversion) (ODA)

2. Transport infrastructure and operating costs (ODA)

3. Infrastructure and regeneration costs (ODA)

4. Support for elite and community sport (public funding)

5. 'Look of London' costs (public funding)

6. Paralympic Games (public funding)

\subsection{Sochi 2014}

The city of Sochi was officially awarded the right to host the 2014 Olympic Winter Games on 4 July 2007. However, the history of big construction sites and urban image changes had started long before Sochi secured the right to host the Olympic Games and even before summer 2005, when the Sochi 2014 Bid Committee was established. Much of the construction was made in general infrastructure, and basically Sochi was largely changed and the Olympic Games merely played a role in this. After Sochi was awarded the right to host the Olympic Winter Games, a new decree no. 991 was approved on 27 December 2007, considering the detailed IOC requirements, but lacking any specification regarding financial support (Anti-Corruption Foundation n. d., 6).

The number of shareholders involved in the financing of infrastructure was extremely high in Sochi. According to Aumüller $(2014,28)$, the Games budget included more than 200 projects that were financed by 
1. Private investors (Wladimir Potanin, Oleg Deripaska, Viktor Wekselberg who invested in the Olympic University, Rosa Chutor (Alpine, Snowboard/Freestyle Park), but also in the harbour, Airport and Hotel)

2. Private investors (UGMK-Holding (Schajba-Arena); Slawoblast (Curling-Centre))

3. State-controlled companies (Gazprom (Nordic skiing and Biathlon centre); Sberbank (jumping hill))

4. State-owned companies (Olympstroy (ice channel, Bolschoi Ice Palace; Fischt-Stadium); Omega (Adler-Arena Oval))

Two state-owned companies, Olympstroy and Russian Railways (RZD) (USD 7.6bn or some 20 infrastructure projects), received over half of the overall federal budget. Olympstroy spent USD 6.3bn on constructing 11 sports venues (Anti-Corruption Foundation n. d., 7).

The figure illustrates the share of these investors on the overall budget.

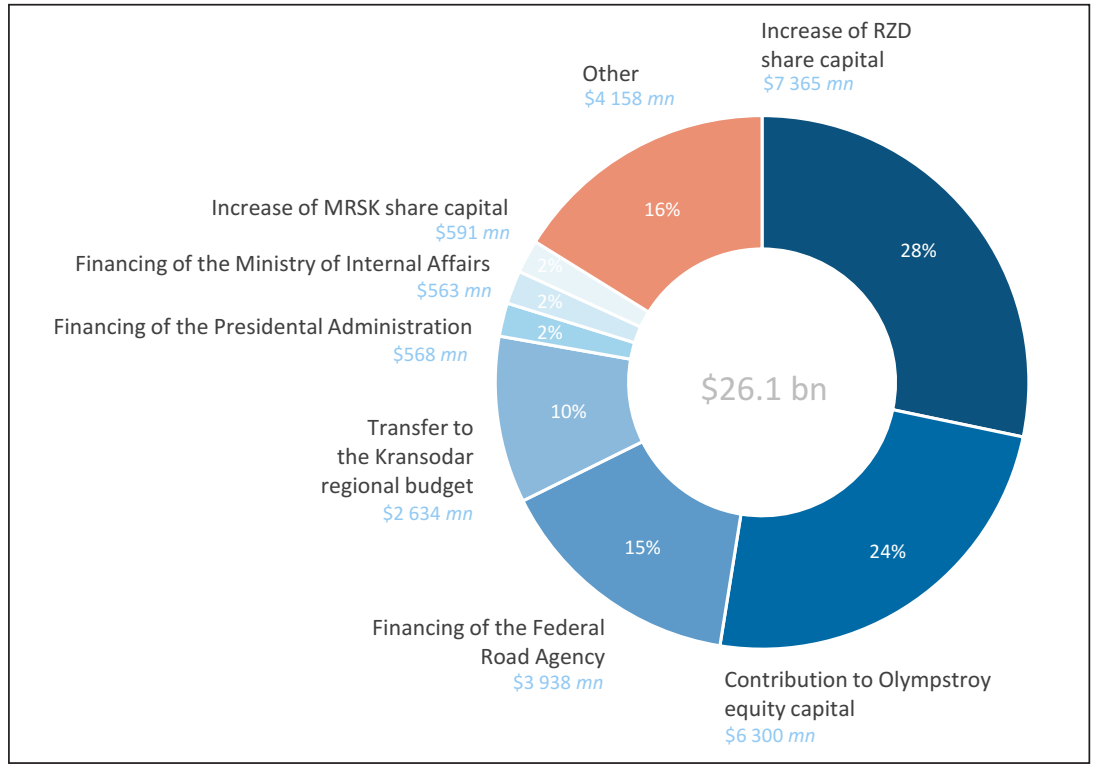

Fig. 35 Financing of the Winter Games Sochi 2014

Sources: Anti-Corruption Foundation (n. d., 7) based on RF Government Decree no. 991, Federal Laws on Budget, Annual reports of Olympstroy and other entities, ACF analyses. 
Out of all investments, only 19\% was used to construct sports venues (Anti-Corruption Foundation n. d., 14). This mix of different investors makes it very difficult to keep track of financial streams.

\subsubsection{SOOC Revenue}

The Sochi 2014 Organising Committee (SOOC) had an approximately $75 \%$ private share of resources. The figures in the following table show that the revenues, unlike for other Games in this study, did not increase. The main reason for this is that the inflation rate was extremely high during that time. From 2007 (bidding time) to 2014, inflation almost doubled the prices, which means that the revenues were reduced by more than 50\% (2007 GDP deflator $=58.9$; in 2014 it was 123.6). Despite the high inflation in Russia, the revenues only decreased by $3 \%$ compared to the bid plan.

Table 37 SOOC revenue evolution of estimates and final

\begin{tabular}{|c|c|c|c|c|c|c|c|c|}
\hline Categories & $\begin{array}{c}\text { Candidature } \\
\text { File (t-8) } \\
\text { (000 RUB) }\end{array}$ & $t-6$ & $t-5$ & $t-4$ & $t-3$ & $t-2$ & $t-1$ & $\begin{array}{c}\text { final } \\
\text { (000 RUB) }\end{array}$ \\
\hline $\begin{array}{l}\text { IOC } \\
\text { Contribution }\end{array}$ & $\begin{array}{c}0 \% \\
(20,141,427)\end{array}$ & & & & $-32 \%$ & $-35 \%$ & $-38 \%$ & $\begin{array}{c}-32 \% \\
(13,647,182)\end{array}$ \\
\hline $\begin{array}{l}\text { Top } \\
\text { Sponsorship }\end{array}$ & $\begin{array}{c}0 \% \\
(11,370,161)\end{array}$ & & & & $-44 \%$ & $-51 \%$ & $-54 \%$ & $\begin{array}{c}-45 \% \\
(6,235,528)\end{array}$ \\
\hline $\begin{array}{l}\text { National } \\
\text { Sponsorship }\end{array}$ & $\begin{array}{c}0 \% \\
(22,740,321)\end{array}$ & & & & $97 \%$ & $69 \%$ & $72 \%$ & $\begin{array}{c}76 \% \\
(40,088,582)\end{array}$ \\
\hline Ticket Sales & $\begin{array}{c}0 \% \\
(8,405,667)\end{array}$ & & & & $-37 \%$ & & $-6 \%$ & $\begin{array}{c}-15 \% \\
(7,152,367)\end{array}$ \\
\hline Licensing & $\begin{array}{c}0 \% \\
(2,306,518)\end{array}$ & & & & $-13 \%$ & $25 \%$ & $-27 \%$ & $\begin{array}{c}-23 \% \\
(1,768,969)\end{array}$ \\
\hline Lotteries & $\begin{array}{c}0 \% \\
(974,585)\end{array}$ & & & & $91 \%$ & $75 \%$ & & \\
\hline \multicolumn{9}{|l|}{ Donations } \\
\hline $\begin{array}{l}\text { Disposal of } \\
\text { Assets }\end{array}$ & $\begin{array}{c}0 \% \\
(802,149)\end{array}$ & & & & & & & \\
\hline Subsidies & $\begin{array}{c}0 \% \\
(27,164,938)\end{array}$ & & & & $-59 \%$ & $-57 \%$ & $-44 \%$ & $\begin{array}{c}-42 \% \\
(15,666,099)\end{array}$ \\
\hline Other & $\begin{array}{c}0 \% \\
(4,693,537)\end{array}$ & & & & $78 \%$ & $253 \%$ & $110 \%$ & $\begin{array}{c}135 \% \\
(11,021,602)\end{array}$ \\
\hline Total & $\begin{array}{c}0 \% \\
(98,599,304)\end{array}$ & & & & $-5 \%$ & $-9 \%$ & $-7 \%$ & $\begin{array}{c}-3 \% \\
(95,580,329)\end{array}$ \\
\hline
\end{tabular}

Sources: Sochi 2014 Bid Committee (2006); SOOC (2011 2012, 2013, 2014) 
The IOC contribution to the staging of the Winter Games increased by more than 50 per cent from 2002. In other words, SOOC did a great job, as nominal figures show a great increase in revenues over the years. Particularly in the area of national sponsorship, it was even able to generate $76 \%$ more revenues, as it was denominated in USD, but paid in Russian roubles - thus SOOC benefited from USD revenues. The "other" category listed a 135\% revenue overrun. All other categories took less than planned, due to high inflation. As a result, a revenue underrun of $-3 \%$ overall can be observed.

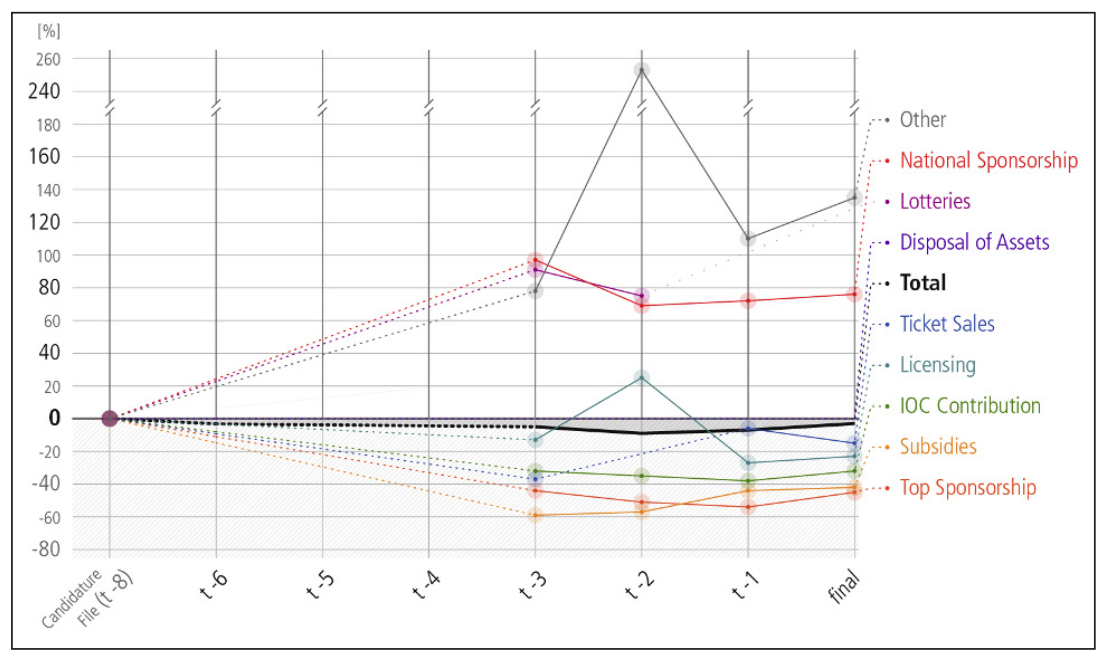

Fig. 36 SOOC revenue evolution of estimates and final

\subsubsection{SOOC Expenditure}

The interpretation of the expenditure has to be seen in terms of the inflation over the time. Much expenditure must have become more expensive. It was therefore a great achievement that the final expenditures of SOOC were $6 \%$ below the estimate in the bid documents. 
Table 38 SOOC expenditure evolution of estimates and final

\begin{tabular}{|c|c|c|c|c|c|c|c|c|}
\hline Categories & $\begin{array}{c}\text { Candidature } \\
\text { File (t-8) } \\
\text { (000 RUB) }\end{array}$ & $t-6$ & $t-5$ & $t-4$ & $t-3$ & $t-2$ & $t-1$ & $\begin{array}{c}\text { final } \\
(000 \text { RUB })\end{array}$ \\
\hline Venues & $\begin{array}{c}0 \% \\
(12,411,537)\end{array}$ & & & & $-41 \%$ & $-46 \%$ & $-36 \%$ & $\begin{array}{c}-33 \% \\
(8,296,734)\end{array}$ \\
\hline Workforce & $\begin{array}{c}0 \% \\
(18,151,389)\end{array}$ & & & & $17 \%$ & $7 \%$ & $6 \%$ & $\begin{array}{c}1 \% \\
(18,243,653)\end{array}$ \\
\hline Technology & $\begin{array}{c}0 \% \\
(16,444,501)\end{array}$ & & & & $-1 \%$ & $-8 \%$ & $-5 \%$ & $\begin{array}{c}-2 \% \\
(16,169,998)\end{array}$ \\
\hline Services & $\begin{array}{c}0 \% \\
(10,967,397)\end{array}$ & & & & $-20 \%$ & $-28 \%$ & $-19 \%$ & $\begin{array}{c}-23 \% \\
(8,427,313)\end{array}$ \\
\hline $\begin{array}{l}\text { Marketing \& } \\
\text { Events }\end{array}$ & $\begin{array}{c}0 \% \\
(12,059,517)\end{array}$ & & & & $2 \%$ & $-13 \%$ & $9 \%$ & $\begin{array}{c}10 \% \\
(13,228,170)\end{array}$ \\
\hline $\begin{array}{l}\text { Administration } \\
\text { \& Coordination }\end{array}$ & $\begin{array}{c}0 \% \\
(11,804,306)\end{array}$ & & & & $-13 \%$ & $-16 \%$ & $-19 \%$ & $\begin{array}{c}-10 \% \\
(10,590,319)\end{array}$ \\
\hline Other & $\begin{array}{c}0 \% \\
(16,760,721)\end{array}$ & & & & $5 \%$ & $21 \%$ & $1 \%$ & $\begin{array}{c}4 \% \\
(17,369,193)\end{array}$ \\
\hline Total & $\begin{array}{c}0 \% \\
(98,599,369)\end{array}$ & & & & $-5 \%$ & $-9 \%$ & $-7 \%$ & $\begin{array}{c}-6 \% \\
(92,325,380)\end{array}$ \\
\hline
\end{tabular}

Sources: Sochi 2014 Bid Committee (2006); SOOC (2011, 2012, 2013, 2014)

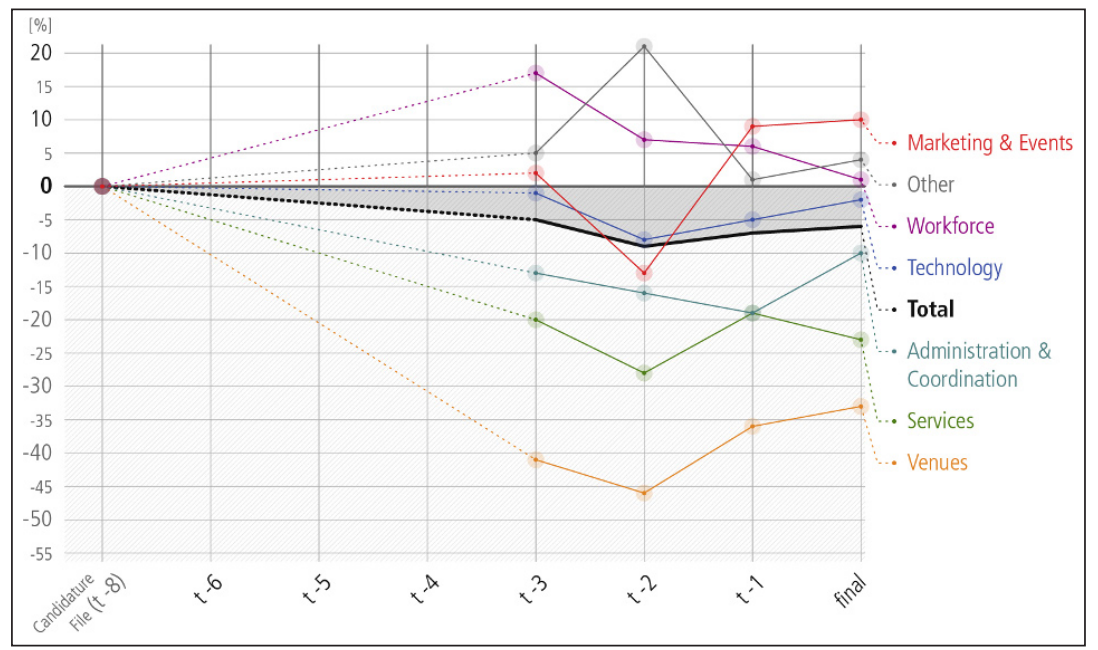

Fig. 37 SOOC expenditure evolution of estimates and final 
It seems that BOCOG and the SOOC kept the workforce and administration expenditure under control, but both had relatively high administration costs compared to other OCOGs. The venues, services and administration \& coordination categories saw a significant decline in costs. On the other hand, the expenditure on the side of workforce, marketing \& events and other was higher than expected. In general, the changes are very moderate, despite the high inflation rate.

\subsubsection{Sochi 2014 Non-OCOG Costs}

All venues were designed specifically for the Olympic Games and included in the:

a. Federal Target programme on Olympic facilities construction and Sochi development as an Alpine ski resort (Decree of the Russian Government no. 991 dated 29.12.2007),

b. Regional Target programme on Olympic facilities construction and Sochi development as an Alpine ski resort (The Decree of the Governor of Krasnodar Krai no. 723 dated 19.08.2009) and

c. Municipal target programme on Olympic facilities construction and Sochi development as an Alpine ski resort (The Decree of the Head of Sochi Administration no. 14 dated 14.01.2011) (Kasimov 2015, 194)

Overall, according to the Anti-Corruption Foundation (n. d.), the cost overruns for the sports venues were very large. Our data show more moderate cost overruns, because we considered the inflation rate. Inflation in Russia was very high between 2007 and 2014, which reduced the perceived cost increase. However, as shown in the next table, it is on average of our "venue basket" at $178 \%$ and the market is the largest of the investigated Olympic Winter Games. 
Table 39 Sochi 2014 non-OCOG cost evolution of estimates and final from public resources

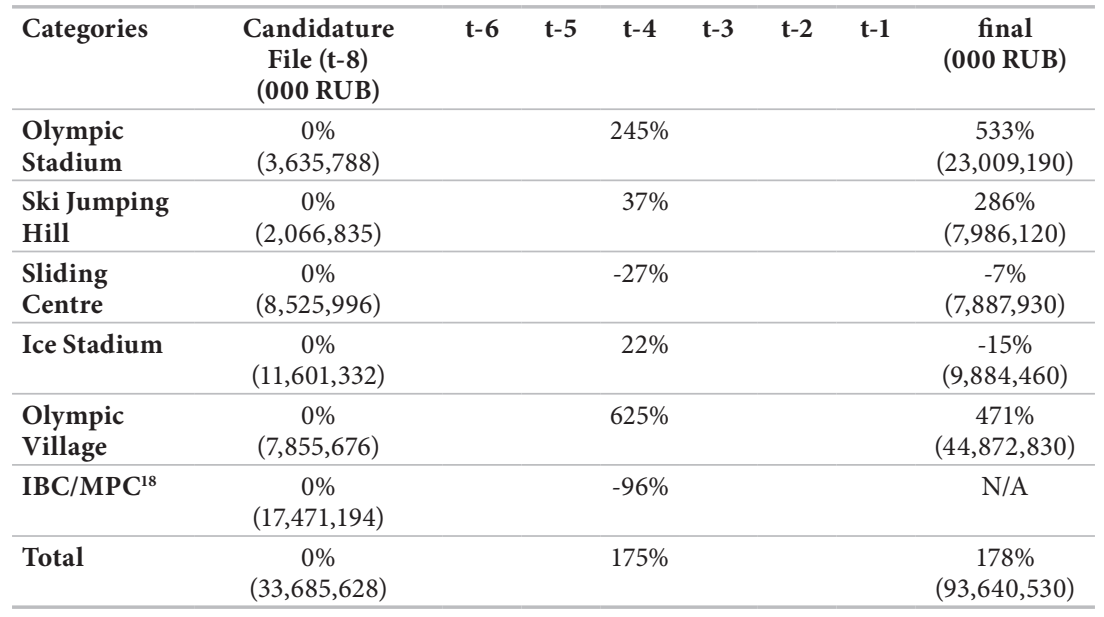

Sources: Anti-Corruption Foundation (n. d.); Aumüller (2014); Müller (2014); Sochi 2014 Bid Committee (2006); SOOC (2010)

Compared to Salt Lake City, we find that Sochi had a totally reverse financing system. While Salt Lake City tried to use almost no public money to finance the sports venues, Sochi was mostly financed by public funds. A large part of the cost of venues was significantly more expensive than actually planned. The highest cost overrun was for the construction of the Olympic Stadium, at 533\%. But for the Olympic Village (471\%) and the ski jumping hill (286\%), the costs also exploded. Nevertheless, money could be saved, which happened during the construction of the sliding centre and the ice stadium. In summary, Sochi had a cost overrun of $178 \%$ in the construction of its sports-related infrastructure.

Sochi had significant cost overruns. The final data (when available) show much higher costs than estimated in the budget in the bid book. Some venues were severely underestimated, such as the Biathlon and Cross-Country Complex, the ski jump and the Olympic Stadium. Looking at bidding data, it seems that the projected costs are so low that only temporary venues or renovations were planned. The massive cost overruns are all the more surprising, considering that the bid book stated that "expenses are forecast on the 'high side,' recognising that expenses for Olympic Winter Games are

$18 \mathrm{IBC} / \mathrm{MPC}$ is not counted in the total amount since the final costs were not available. 
typically underestimated at this stage" (Sochi 2014 Bidding Committee 2006, 99). As Sochi did not have a sufficient number of venues, it should be asked why no one (and in particular the well informed IOC) put pressure on Sochi to have a more realistic budget. The non-OCOG budget was developed by the Ministry of Development and Trade. However, in our recommendations we will come back to this point.

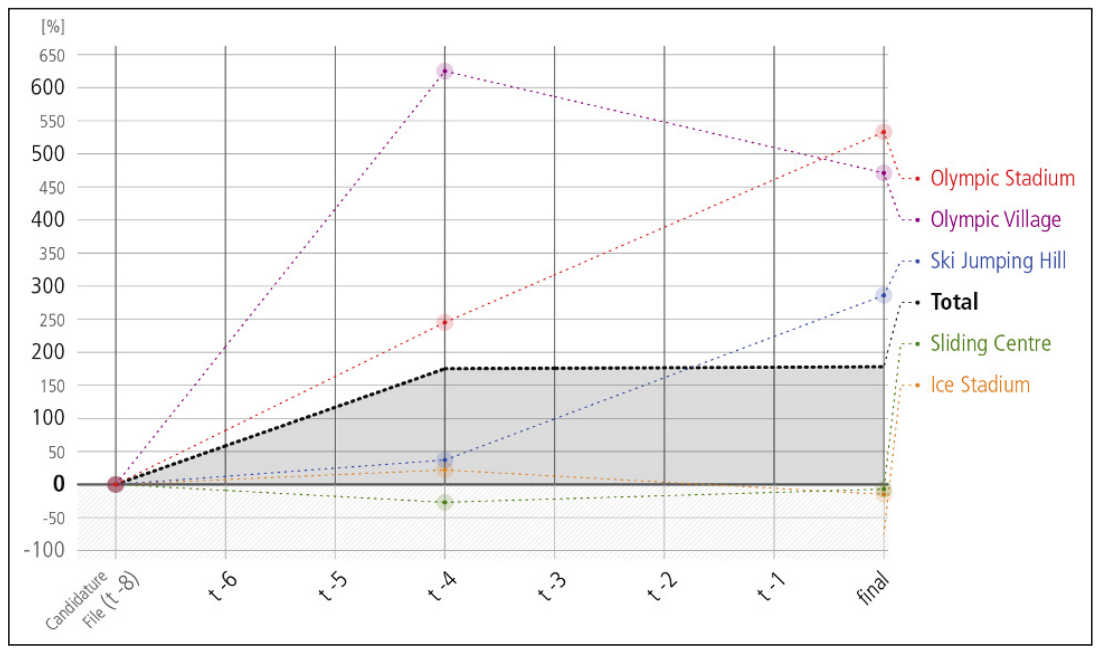

Fig. 38 Sochi 2014 non-OCOG cost evolution of estimates and final from public resources

Müller (2014) explains some reasons for the cost overruns:

Changing Masterplan: The Biathlon and Cross-Country complex had to be relocated and had to have a separate "endurance village" for competing athletes, because of the elevation difference with the Mountain Olympic Village.

Standards: Some venues had to conform to international sustainable building standards, a requirement that was introduced after the bid.

Economic Crises: In 2009, Russia's GDP lost 7.8\% during the financial crisis.

A further burden was the exchange rate and inflation. During the seven years of construction, inflation was very high and almost doubled the prices. But the change 
in the exchange rate also had a massive impact, as the US dollar was $30 \%$ more expensive, meaning that all imports became more expensive (see methodology section).

\subsection{Rio de Janeiro 2016}

The bidding for these Games began on 28 July 2006, when the Executive Council of the Brazilian Olympic Committee met to nominate a Brazilian city to host the Games in 2016. Only in October 2007 did Rio officials attend the 2016 Applicant Cities Seminar organised by the IOC in Lausanne, where they learnt more about technical areas that would be analysed throughout the application process. In our recommendations we will come back to this point of needed IOC support. Rio officials participated in the Olympic Games Observer Programme from August during the Beijing 2008 Olympic Games and received further insights into the necessary infrastructure etc. for staging the Olympic Games. On 11 February 2009, the Rio de Janeiro bid committee delivered its Candidature File, and later that year, in October 2009, four new sports entered the programme. Thus, additional planning and increased costs became obvious. It was at the same Session in Copenhagen that Rio was elected as the host city.

The Olympic Games in Rio de Janeiro experienced several changes in their master planning after being awarded the Games. The main changes in relation to the original budget were:

1. the impact of the adjustment based on Brazil's Consumer Price Index (IPCA),

2. the inclusion of four new sports (golf, rugby, paracanoe and paratriathlon),

3. new technologies,

4. Games security,

5. average salary increases above inflation,

6. spending on usage and retrofitting of the Olympic Village.

This list shows a quite typical pattern of cost overruns that previous host cities also had. Inflation and salary changes are changes in the environment and happen irrespective of the Games development. Changes to the master plan can also occur, and adding rugby and golf to the Games schedule meant the need for new venues. The most difficult thing to plan is Games security. In Rio, that was resolved at the last minute by putting the military and police in charge. Security has become an important cost issue at the Olympic Games, as it was in Rio. 
The Brazilian Ministry of Defence created the Special Advisory Committee for Major Events, to the Joint Staff of the Armed Forces, which used the Joint Operations Centre as the venue for coordination and monitoring of the action to be taken by Brazil's three armed forces. The Brazilian Intelligence Agency, the entity responsible for planning, implementing, coordinating, supervising and controlling intelligence activities in Brazil, was defined as the centralising entity that had to coordinate the work of all other entities of the Brazilian Intelligence System. It was also responsible for preparing risk assessments, producing knowledge, preventing terrorism and disseminating information, which it did through the National Intelligence Centre and the Regional Intelligence Centres established in the host cities of the Games (Social Communication Secretariat 2016, 4).

All investments made in safety and security for the Games had as a basis premise their subsequent return to society as a legacy for the everyday life of public safety. The Ministry of Justice invested BRL 1,500m in security for the major events (BRL 1,170m already spent on the 2014 FIFA World Cup). The Ministry of Defence's budget for security for the Rio 2016 Olympic and Paralympic Games was BRL 704.4m, BRL 275m of which was invested in 2014 and BRL 183.9m in 2015. An additional BRL 150m was provided for in the Annual Budget Law for 2016. In addition a provisional decree was issued, granting an additional BRL $95.5 \mathrm{~m}$ to the Ministry of Defence. The funds were meant to finalise equipment purchases and fund activities by the armed forces aimed at ensuring the security of the Rio 2016 Games (Social Communication Secretariat 2016, 4).

\subsubsection{COJOPR Revenue}

The Rio 2016 Organising Committee for the Olympic Games (COJOPR) was established on 8 April 2010, with its headquarters in Rio de Janeiro. The Organising Committee has not yet wound up, although this usually happens in the same year of the Games. Therefore, for the present calculation of changes in revenues and expenses, only the budget which was published shortly after the Games has been used, rather than a final budget. The COJOPR operates as a private, non-profit civil society of an educational, cultural, artistic and sports nature, and its principal activity was the promotion, organisation and staging of the Olympic and Paralympic Games in Brazil in 2016. On 23 January 2014, the COJOPR publicly disclosed its first revision of the Games budget following the bid, highlighting a balanced budget using only private resources (COJOPR 2015, 11). This was only two-and-a-half years before the Games started. 
The original COJOPR budget as set out in the Candidature File was around USD $2,800 \mathrm{~m}$, to be funded by three contributors:

1. the IOC,

2. subsidies from federal, state and municipal governments (divided into equal parts),

3. private funds (sponsorships, licencing and ticket sales) (SCU 2014, 191).

A revised budget was disclosed in January 2014, and it had increased to USD 3,000m. The increase was justified by the inclusion of four new sports. It is interesting to note that the previously planned subsidies (see above point 2 ) for the COJOPR were eliminated in 2014 (SCU 2014, 192). This was a strategic decision by the COJOPR not to receive government subsidies in order to maintain the "private" funded company status. Instead, the COJOPR was trying to push the government to undertake directly some of the costs, such as sports equipment and energy.

Tab. 40 shows the revenue evolution of the COJOPR estimates.

Table 40 COJOPR revenue evolution of estimates

\begin{tabular}{|c|c|c|c|c|c|c|c|c|}
\hline Categories & $\begin{array}{c}\text { Candidature } \\
\text { File (t-8) } \\
(000 \text { BRL) }\end{array}$ & $t-6$ & $t-5$ & $t-4$ & $t-3$ & $t-2$ & $t-1$ & final \\
\hline $\begin{array}{l}\text { IOC } \\
\text { Contribution }\end{array}$ & $\begin{array}{c}0 \% \\
(2,146,104)\end{array}$ & & & $-27 \%$ & $-15 \%$ & $-7 \%$ & $0 \%$ & N/A \\
\hline $\begin{array}{l}\text { Top } \\
\text { Sponsorship }\end{array}$ & $\begin{array}{c}0 \% \\
(1,065,104)\end{array}$ & & & $-14 \%$ & $-23 \%$ & $-11 \%$ & $-13 \%$ & N/A \\
\hline $\begin{array}{l}\text { National } \\
\text { Sponsorship }\end{array}$ & $\begin{array}{c}0 \% \\
(1,891,669)\end{array}$ & & & $134 \%$ & $133 \%$ & $116 \%$ & $70 \%$ & N/A \\
\hline Ticket Sales & $\begin{array}{c}0 \% \\
(1,330,514)\end{array}$ & & & $76 \%$ & $-14 \%$ & $3 \%$ & $-5 \%$ & N/A \\
\hline Licensing & $\begin{array}{c}0 \% \\
(165,936)\end{array}$ & & & $11 \%$ & $3 \%$ & $14 \%$ & $4 \%$ & N/A \\
\hline Lotteries & & & & & & & & N/A \\
\hline Donations & $\begin{array}{c}0 \% \\
(110,624)\end{array}$ & & & & & & & N/A \\
\hline $\begin{array}{l}\text { Disposal of } \\
\text { Assets }\end{array}$ & $\begin{array}{c}0 \% \\
(120,888)\end{array}$ & & & $-7 \%$ & & & $-88 \%$ & N/A \\
\hline Subsidies & $\begin{array}{c}0 \% \\
(2,551,966)\end{array}$ & & & $-7 \%$ & & & & N/A \\
\hline Other & $\begin{array}{c}0 \% \\
(997,962)\end{array}$ & & & $437 \%$ & $-67 \%$ & $-61 \%$ & $-11 \%$ & N/A \\
\hline Total & $\begin{array}{c}0 \% \\
(10,380,766)\end{array}$ & & & $24 \%$ & $-16 \%$ & $-14 \%$ & $-17 \%$ & N/A \\
\hline
\end{tabular}

Sources: COJOPR (2015, 2016a, b); Rio 2016 Candidate City (2008) 
In the table above we had difficulty in displaying a percentage of a position that was taken out. However, the total revenue development up to one year before the Games shows that the COJOPR probably had a revenue underrun.

The COJOPR is not yet wound up, so there is no final data available. One year before the Games, it seemed that it had a great income through national sponsors, but almost all other categories took less than first expected.

\subsubsection{COJOPR Expenditure}

As with the revenue, there are no final figures in the expenditure of the COJOPR. The cost underrun was measured as being $17 \%$ a year before the Games. However, this means that a part of the budget is still estimated and only the final figures can show how the COJOPR will wind up. However, it looks like money could be saved in the category of workforce. In addition, the other categories show moderate changes. Even with regard to venues, the COJOPR was able to save a lot. One reason was the cutbacks for the city dressing programme. The expenditures seem to have become more predictable than for the previous Games, so the next host cities will benefit from the knowledge of the past ones.

Table 41 COJOPR expenditure evolution of estimates

\begin{tabular}{|c|c|c|c|c|c|c|c|c|}
\hline Categories & $\begin{array}{c}\text { Candidature } \\
\text { File (t-8) } \\
(000 \text { BRL) }\end{array}$ & $t-6$ & $t-5$ & $t-4$ & $t-3$ & $t-2$ & $t-1$ & final \\
\hline Venues & $\begin{array}{c}0 \% \\
(2,525,870)\end{array}$ & & & $-29 \%$ & $-94 \%$ & $-20 \%$ & $-36 \%$ & N/A \\
\hline Workforce & $\begin{array}{c}0 \% \\
(1,260,954)\end{array}$ & & & $93 \%$ & $45 \%$ & $24 \%$ & $-73 \%$ & N/A \\
\hline Technology & $\begin{array}{c}0 \% \\
(1,800,592)\end{array}$ & & & $16 \%$ & $-17 \%$ & $-12 \%$ & $12 \%$ & N/A \\
\hline Services & $\begin{array}{c}0 \% \\
(1,048,440)\end{array}$ & & & $63 \%$ & $-63 \%$ & $-40 \%$ & $-23 \%$ & N/A \\
\hline $\begin{array}{l}\text { Marketing \& } \\
\text { Events }\end{array}$ & $\begin{array}{c}0 \% \\
(1,609,760)\end{array}$ & & & $-29 \%$ & $-39 \%$ & $-41 \%$ & $-21 \%$ & N/A \\
\hline $\begin{array}{l}\text { Administration } \\
\text { \& Coordination }\end{array}$ & $\begin{array}{c}0 \% \\
(789,066)\end{array}$ & & & $-58 \%$ & $16 \%$ & $45 \%$ & $34 \%$ & N/A \\
\hline Other & $\begin{array}{c}0 \% \\
(1,346,086)\end{array}$ & & & $149 \%$ & $119 \%$ & $116 \%$ & $13 \%$ & N/A \\
\hline Total & $\begin{array}{c}0 \% \\
(10,380,768)\end{array}$ & & & $24 \%$ & $-16 \%$ & $4 \%$ & $-17 \%$ & N/A \\
\hline
\end{tabular}

Sources: COJOPR $(2015,2016 a, b)$; Rio 2016 Candidate City (2008) 


\subsubsection{Rio 2016 Non-OCOG Costs}

Kao (2016) states that construction for the Olympic Games Rio 2016 were subjected to even heavier scrutiny than for previous Games. There were protests over costs; while political unrest, a recession and environmental concerns drew attention to the vast construction undertaking, the cost of which made up a large portion of the overall Rio Games budget.

Here, additional reasons for the cost overruns become obvious:

1. political instability and, connected to that, a high level of corruption in Rio,

2. recession, which meant budget pressure on the government and a higher unemployment rate,

3. environmental concerns, which may translate into additional expenditure to clean the water in Guanabara Bay or fight mosquitos (and fight the Zika virus).

As the Games accounts have not yet been completed, no information can be provided on the final cost. The venues we surveyed showed no cost overruns in the non-final figures that were available to us. Nevertheless, we do not want to rule that out in the other areas - infrastructure and transport cost overruns could have occurred, as has repeatedly been communicated in the media.

\subsection{PyeongChang 2018}

PyeongChang was elected as the host city in Durban on 6 July 2011. Undoubtedly, the train connection from Seoul to PyeongChang was the most expensive project, even though one must question whether this investment is purely Olympic or if the trainline is also useful to connect a recreational area to Seoul.

\subsubsection{POCOG Revenue}

The total projected income of the PyeongChang Organising Committee for the 2018 Olympic \& Paralympic Winter Games (POCOG) is KRW 2.273 trillion (Park 2016, 325). The source of this money is, as for previous Games, IOC subsidies, TOP Partners, domestic sponsors, Olympic Torch Relay, tickets, licensing, food and beverage, accommodation, broadcasting rights fees, interest allowance and government subsidies (see table below). 
The income for each year has been found to be (Park 2016, 325):

- KRW 49,600m in 2014,

- KRW 206,400m in 2015, and

- KRW 459,000m in 2016.

Table 42 POCOG revenue evolution of estimates and final total

\begin{tabular}{|c|c|c|c|c|c|c|c|c|}
\hline Categories & $\begin{array}{c}\text { Candidature } \\
\text { File (t-8) } \\
(000 \text { KRW })\end{array}$ & $t-6 \quad t-5$ & $t-4$ & $t-3$ & $t-2$ & $t-1$ & $\begin{array}{c}\mathrm{t} \\
\text { pre } \\
\text { Games }\end{array}$ & $\begin{array}{c}\text { final } \\
(000 \mathrm{KRW})\end{array}$ \\
\hline $\begin{array}{l}\text { IOC } \\
\text { Contribution }\end{array}$ & $\begin{array}{c}0 \% \\
(453,635,532)\end{array}$ & & $-8 \%$ & $4 \%$ & $4 \%$ & & $2 \%$ & N/A \\
\hline $\begin{array}{l}\text { Top } \\
\text { Sponsorship }\end{array}$ & $\begin{array}{c}0 \% \\
(206,244,726)\end{array}$ & & $-8 \%$ & $-8 \%$ & $14 \%$ & & $23 \%$ & N/A \\
\hline $\begin{array}{l}\text { National } \\
\text { Sponsorship }\end{array}$ & $\begin{array}{c}0 \% \\
(642,907,500)\end{array}$ & & $36 \%$ & $39 \%$ & $36 \%$ & & $33 \%$ & N/A \\
\hline Ticket Sales & $\begin{array}{c}0 \% \\
(311,295,812)\end{array}$ & & $-40 \%$ & $-44 \%$ & $-41 \%$ & & $-42 \%$ & N/A \\
\hline Licensing & $\begin{array}{c}0 \% \\
(45,003,525)\end{array}$ & & $-19 \%$ & $120 \%$ & $130 \%$ & & $118 \%^{19}$ & N/A \\
\hline Lotteries & $\begin{array}{c}0 \% \\
(19,287,225)\end{array}$ & & & & & & & N/A \\
\hline Donations & $\begin{array}{c}0 \% \\
(28,287,930)\end{array}$ & & $627 \%$ & $156 \%$ & $155 \%$ & & $664 \%$ & N/A \\
\hline $\begin{array}{l}\text { Disposal of } \\
\text { Assets }\end{array}$ & $\begin{array}{c}0 \% \\
(9,000,705)\end{array}$ & & $-8 \%$ & $-6 \%$ & $14 \%$ & & $123 \%$ & $\mathrm{~N} / \mathrm{A}$ \\
\hline Subsidies & $\begin{array}{c}0 \% \\
(167,155,950)\end{array}$ & & $93 \%$ & $97 \%$ & $146 \%$ & & $194 \%$ & N/A \\
\hline Other & $\begin{array}{c}0 \% \\
(85,763,861)\end{array}$ & & $9 \%$ & $73 \%$ & $74 \%$ & & $92 \%$ & N/A \\
\hline Total & $\begin{array}{c}0 \% \\
(1,968,582,765)\end{array}$ & & $19 \%$ & $21 \%$ & $27 \%$ & & $39 \%$ & $\begin{array}{c}27 \% \\
(2,506,991,500)\end{array}$ \\
\hline
\end{tabular}

Sources: POCOG (2014, 2016, 2018); PyeongChang 2018 Olympic \& Paralympic Winter Games Bid Committee (2010)

19 POCOG had reflected the gross coin revenue (unlike other OCOGs), which meant it had a very high revenue and high costs due to production. This representation was not in the Candidature File. 
As the Olympic Games were in progress at the time of the survey, the last budget projection was produced just before the Games, and, like for Rio 2016, there is also no final data available. The changes for POCOG were much bigger than those in Rio. As a result, $664 \%$ more revenue was generated by donations. But most other categories were also able to generate more revenues. Only a single category has not taken as much as was planned in the Candidature File. With ticket sales falling short of the pace seen at past Games, POCOG had a big loss here. However, in a way, that was expected as the shortfall had already been predicted four years before. In total, POCOG had an estimated 39\% revenue overrun just before the Games than originally planned.

Based on the recent report of POCOG to the IOC Executive Board and according to the preliminary financial information the POCOG budget has a surplus of about US $\$ 55 \mathrm{~m}$. Detailed data are not yet known as POCOG is in its final stage of financial reconciliation.

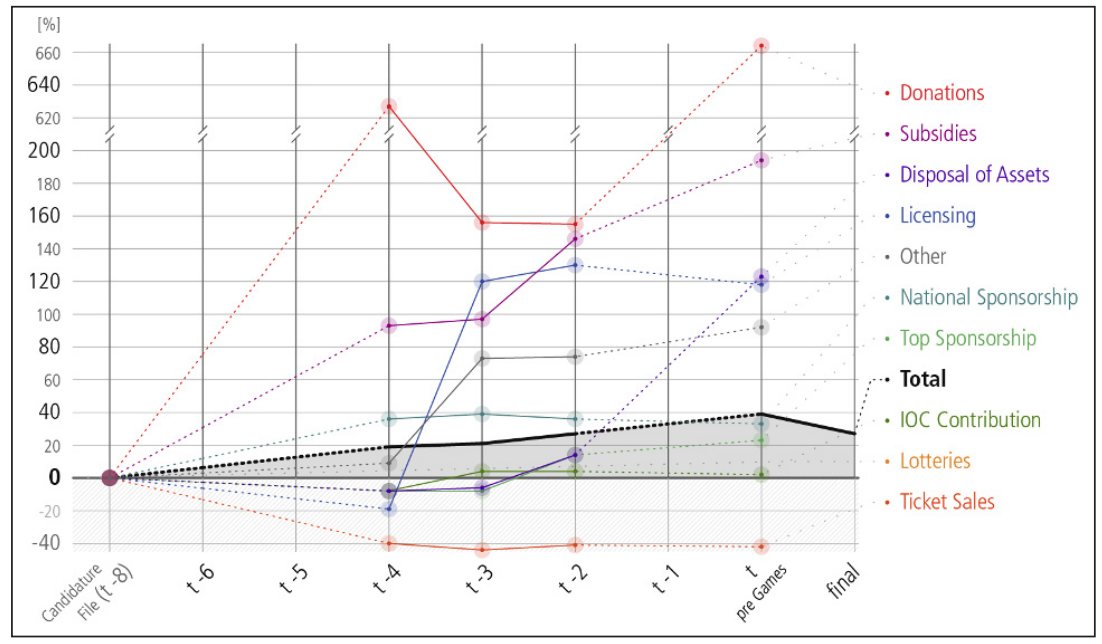

Fig. 39 POCOG revenue evolution of estimates and final total

\subsubsection{POCOG Expenditure}

The total projected expenditure of POCOG is KRW 2.273 trillion, and will therefore balance off the revenues (Park 2016, 326). 
Our latest output figures are also estimated editions shortly before the Games. So the figures presented above are not guaranteed to be the final figures. As for the previous Games, expenditure was highest two years before the Games, which was reduced just before the Games. Compared to the revenue of POCOG, the sway is not that strong. Despite this, all categories were more expensive than planned at the time of the Candidature File. The highest cost increase was experienced in the administration \& coordination category $(82 \%)$, whereas the category technology had only a slight increase (5\%). In summary, the projection of POCOG's expenditure just before the Games was 38\% more expensive than was assumed in the Candidature File.

Table 43 POCOG expenditure evolution of estimates and final total

\begin{tabular}{|c|c|c|c|c|c|c|c|c|}
\hline Categories & $\begin{array}{l}\text { Candidature } \\
\text { File (t-8) } \\
(000 \text { KRW })\end{array}$ & $t-6 \quad t-5$ & $t-4$ & $t-3$ & $t-2$ & $t-1$ & $\begin{array}{c}\mathbf{t} \\
\text { pre } \\
\text { Games }\end{array}$ & $\begin{array}{c}\text { final } \\
(000 \mathrm{KRW})\end{array}$ \\
\hline Venues & $\begin{array}{c}0 \% \\
(405,803,214)\end{array}$ & & $-5 \%$ & $22 \%$ & $65 \%$ & & $61 \%$ & N/A \\
\hline Workforce & $\begin{array}{c}0 \% \\
(243,404,780)\end{array}$ & & $64 \%$ & $4 \%$ & $26 \%$ & & $17 \%$ & N/A \\
\hline Technology & $\begin{array}{c}0 \% \\
(488,866,863)\end{array}$ & & $5 \%$ & $-7 \%$ & $6 \%$ & & $5 \%$ & N/A \\
\hline Services & $\begin{array}{c}0 \% \\
(201,744,374)\end{array}$ & & $-11 \%$ & $-6 \%$ & $32 \%$ & & $34 \%$ & N/A \\
\hline $\begin{array}{l}\text { Marketing \& } \\
\text { Events }\end{array}$ & $\begin{array}{c}0 \% \\
(267,063,776)\end{array}$ & & $35 \%$ & $45 \%$ & $87 \%$ & & $76 \%$ & N/A \\
\hline $\begin{array}{l}\text { Administration } \\
\text { \& Coordination }\end{array}$ & $\begin{array}{c}0 \% \\
(152,754,822)\end{array}$ & & $50 \%$ & $70 \%$ & $51 \%$ & & $82 \%$ & N/A \\
\hline Other & $\begin{array}{c}0 \% \\
(208,944,938)\end{array}$ & & $26 \%$ & $64 \%$ & $105 \%$ & & $21 \%$ & N/A \\
\hline Total & $\begin{array}{c}0 \% \\
(1,968,582,765)\end{array}$ & & $19 \%$ & $21 \%$ & $48 \%$ & & $38 \%$ & $\begin{array}{c}24 \% \\
(2,445,573,000)\end{array}$ \\
\hline
\end{tabular}

Sources: POCOG (2014, 2016, 2018); PyeongChang 2018 Olympic \& Paralympic Winter Games Bid Committee (2010) 


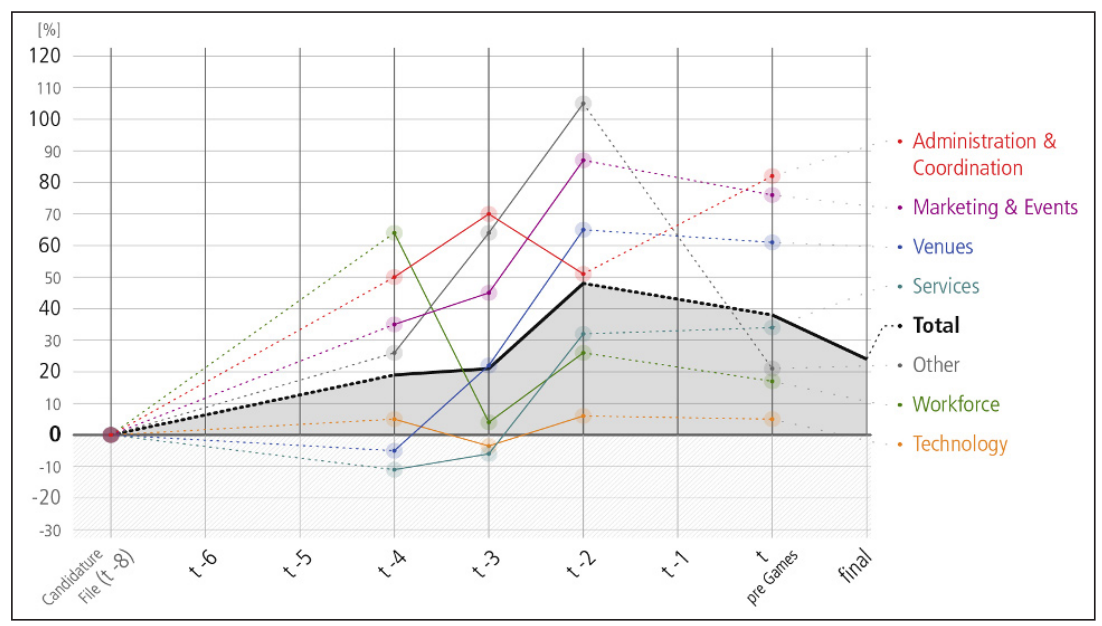

Fig. 40 POCOG expenditure evolution of estimates and final total

\subsubsection{PyeongChang 2018 Non-OCOG Costs}

Our most recent indication of non-OCOG costs is one year before the Games took place. The non-OCOG costs appear here as having no cost overruns. This is due to a massive saving on the Olympic Village, which was financed privately, which compensates the other cost overruns. Further savings could be made through fewer costs for the construction of the ice stadium. Costs for the Olympic Stadium and the ski jumping hill were not specified in the Candidature File, which is why these additional costs are only reflected in the total sum. In addition, the sliding centre and the IBC/MPC were more expensive than originally stated. All in all, the basket of venues in PyeongChang came to an estimated 26\% cost underrun one year before the Games were staged. However, these are not the final figures.

The IOC tried to save costs and started to look at post-Games utilisation. For example, the IOC may have had awarded the Sliding Centre to Japan in order to save on constructing the new venue in PyeongChang. However, the Koreans wanted to have their own track and, above all, avoid co-hosting an event with Japan. If the Host City Contract had bound South Korea to having the Sliding Centre in Japan, it would not have invested in a venue that most probably will have problems being used in future. This problem is specified in the recommendation part. 
Table 44 PyeongChang 2018 non-OCOG cost evolution of estimates from public resources

\begin{tabular}{|c|c|c|c|c|c|c|c|c|}
\hline Categories & $\begin{array}{c}\text { Candidature } \\
\text { File (t-8) } \\
(000 \text { KRW })\end{array}$ & $t-6$ & $t-5$ & $t-4$ & $t-3$ & $t-2$ & $t-1$ & final \\
\hline $\begin{array}{l}\text { Olympic } \\
\text { Stadium }\end{array}$ & & & & & & & $0 \%$ & N/A \\
\hline $\begin{array}{l}\text { Ski Jumping } \\
\text { Hill }\end{array}$ & & & & & & & $0 \%$ & N/A \\
\hline $\begin{array}{l}\text { Sliding } \\
\text { Centre }\end{array}$ & $\begin{array}{c}0 \% \\
(90,392,795)\end{array}$ & & & & & & $26 \%$ & N/A \\
\hline Ice Stadium & $\begin{array}{c}0 \% \\
(129,738,734)\end{array}$ & & & & & & $-3 \%$ & N/A \\
\hline $\begin{array}{l}\text { Olympic } \\
\text { Village }\end{array}$ & $\begin{array}{c}0 \% \\
(912,671,487)\end{array}$ & & & & & & $-57 \%$ & N/A \\
\hline IBC/MPC & $\begin{array}{c}0 \% \\
(64,629,590)\end{array}$ & & & & & & $71 \%$ & N/A \\
\hline Total & $\begin{array}{c}0 \% \\
(1,197,432,605)\end{array}$ & & & & & & $-26 \%$ & N/A \\
\hline
\end{tabular}

Sources: Hong (2017); IOC data; PyeongChang 2018 Olympic \& Paralympic Winter Games Bid Committee (2010)

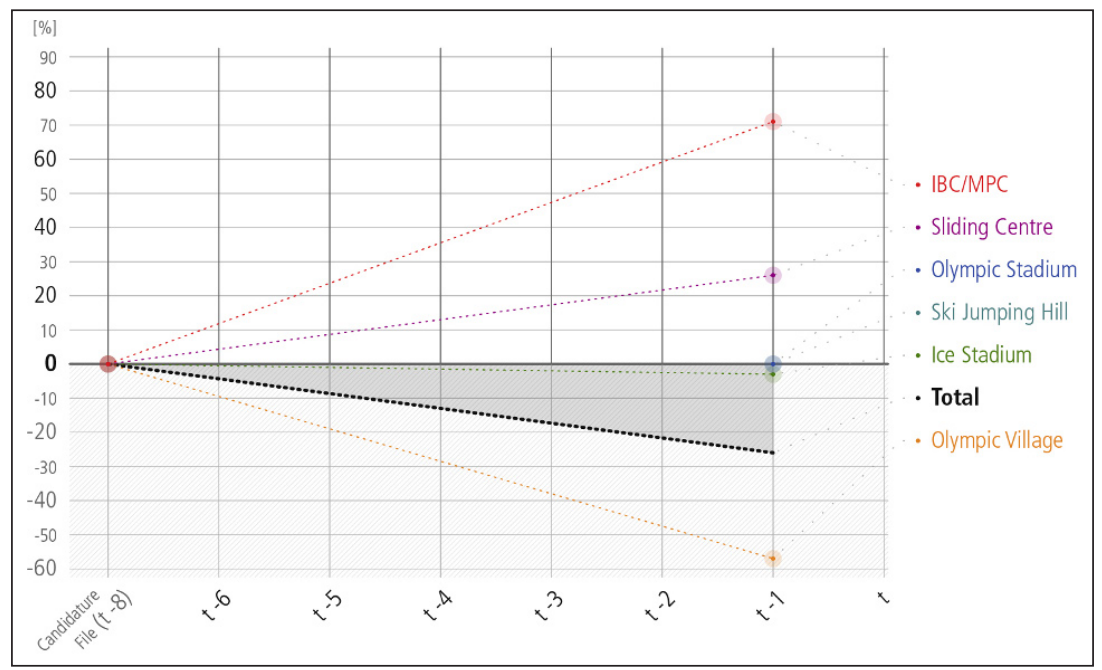

Fig. 41 PyeongChang 2018 non-OCOG cost evolution of estimations from public resources 


\subsection{Summary of Costs and Revenues of the Olympic Games}

All Olympic Games had more revenues and expenses than had been estimated in the candidature file. No OCOGs made any losses. The cost of non-OCOG investments ranged from $29 \%$ to $56 \%$.

Table 45 Total cost and revenue overruns/underruns for the Olympic Games

\begin{tabular}{lccccc}
\hline & $\begin{array}{c}\text { Sydney } \\
2000\end{array}$ & $\begin{array}{c}\text { Athens } \\
2004\end{array}$ & $\begin{array}{c}\text { Beijing } \\
2008\end{array}$ & $\begin{array}{c}\text { London } \\
2012\end{array}$ & $\begin{array}{c}\text { Rio } \\
2016\end{array}$ \\
\hline $\begin{array}{l}\text { OCOG } \\
\text { Revenue }\end{array}$ & $72 \%$ & $51 \%$ & $8 \%$ & $50 \%$ & N/A \\
\hline $\begin{array}{l}\text { OCOG } \\
\text { Expenditure }\end{array}$ & $51 \%$ & $30 \%$ & $4 \%$ & $48 \%$ & N/A \\
\hline Non-OCOG & $56 \%$ & $29 \%^{20}$ & N/A & $43 \%$ & N/A \\
\hline
\end{tabular}

Table 46 Total cost and revenue overruns/underruns for the Olympic Winter Games

\begin{tabular}{lccccc}
\hline & $\begin{array}{c}\text { Salt Lake } \\
\text { City 2002 }\end{array}$ & $\begin{array}{c}\text { Turin } \\
2006\end{array}$ & $\begin{array}{c}\text { Vancouver } \\
2010\end{array}$ & $\begin{array}{c}\text { Sochi } \\
2014\end{array}$ & $\begin{array}{c}\text { Pyeong- } \\
\text { Chang 2018 }\end{array}$ \\
\hline $\begin{array}{l}\text { OCOG } \\
\text { Revenue }\end{array}$ & $119 \%$ & N.A. & $12 \%$ & $-3 \%$ & $27 \%$ \\
\hline $\begin{array}{l}\text { OCOG } \\
\text { Expenditure }\end{array}$ & $114 \%$ & $58 \%$ & $12 \%$ & $-6 \%$ & $24 \%$ \\
\hline Non-OCOG & $28 \%$ & $20 \%$ & $13 \%$ & $178 \%$ & N/A \\
\hline
\end{tabular}

For the Olympic Winter Games, all of them except Sochi 2014 had more revenue and expenses than they had estimated in the candidature file. Again, no OCOGs made a loss. The cost for non-OCOG investments ranged from $13 \%$ to $178 \%$. These results indicate that the organisation of the Olympic Winter Games is not as easy as for the Olympic Games.

20 Additional venues were considered. 


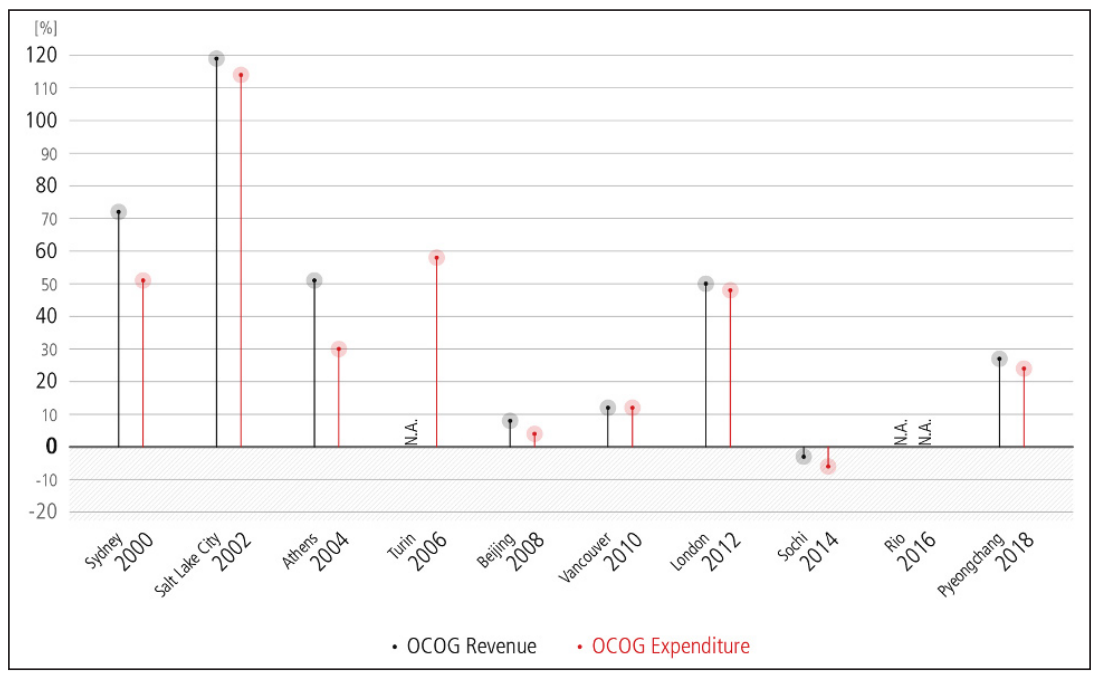

Fig. 42 OCOG revenues and expenditures for the Olympic Games and Olympic Winter Games

We can state that all the organising committees received more revenue than they had expenditures, with the exception of Vancouver 2010 and Rio 2016, which had a balanced budget. That means all other Games made a profit. It also becomes clear that all but Sochi 2014 had more income and expenses than they had assumed in the candidature file. Beijing 2008, Vancouver 2010, Sochi 2014 and Rio 2016 were very close to their estimates, while Sydney 2000, Salt Lake City 2002, Athens 2004, Turin 2006, London 2012 and PyeongChang 2018 deviated by more than $24 \%$ to almost $120 \%$. 


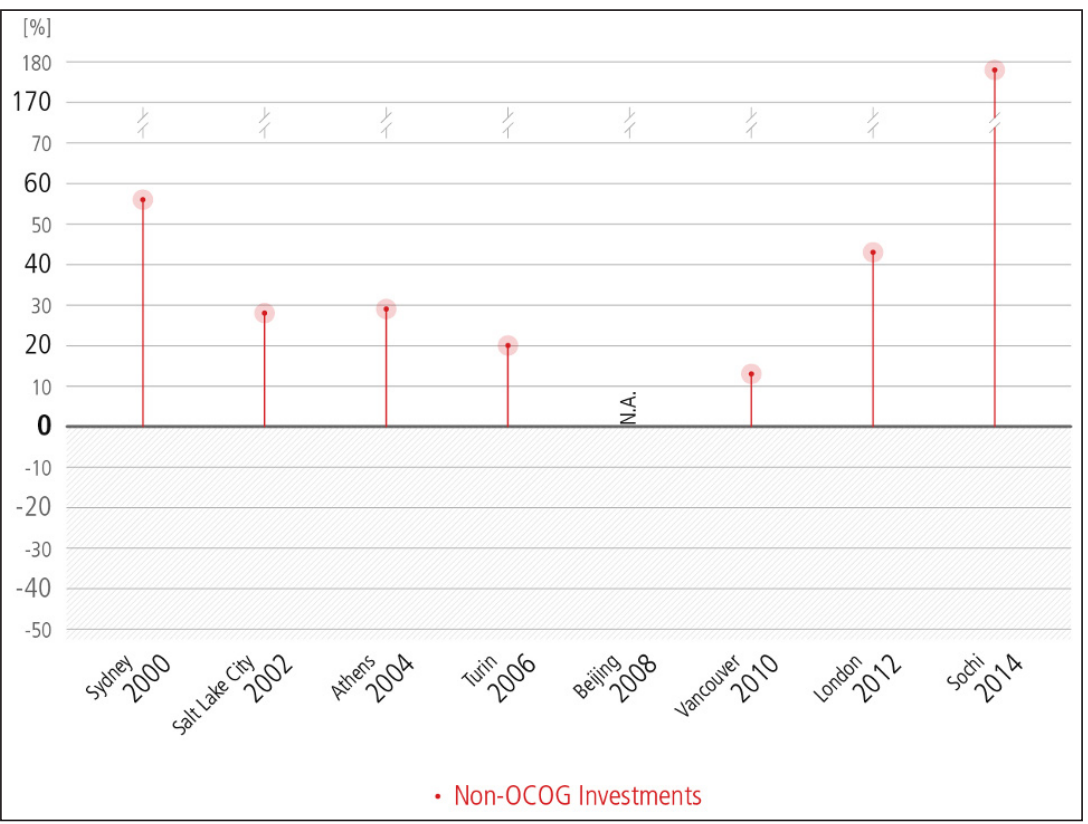

Fig. 43 Non-OCOG investments for the Olympic Games and Olympic Winter Games

From Sydney 2000 to Sochi 2014, the non-OCOG costs were more than estimated in the candidature file. The highest rate was Sochi 2014 with $178 \%$.

Open Access This chapter is licensed under the terms of the Creative Commons Attribution 4.0 International License (http://creativecommons.org/licenses/by/4.0/), which permits use, sharing, adaptation, distribution and reproduction in any medium or format, as long as you give appropriate credit to the original author(s) and the source, provide a link to the Creative Commons licence and indicate if changes were made.

The images or other third party material in this chapter are included in the chapter's Creative Commons licence, unless indicated otherwise in a credit line to the material. If material is not included in the chapter's Creative Commons licence and your intended use is not permitted by statutory regulation or exceeds the permitted use, you will need to obtain permission directly from the copyright holder.

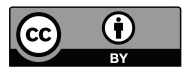




\section{Results II}

In this Results II section, we look separately at OCOG revenue and expenditure categories and also at the individual venues in the non-OCOG budgets. To do so, we first separate the data by distinguishing between the Olympic Games and the Olympic Winter Games. We display for each category the minimum and maximum final deviations from the projected budget to the final budget and its evolution. We added a line representing the average development of the category for the respective five Olympic Games/Olympic Winter Games. Thus, the following graphs show a so-called "uncertainty corridor". The bigger the corridor is, the higher the uncertainty about cost and revenue development. Strong fluctuations in the mean value result mostly from the lack of values at a given time.

\subsection{Revenue Corridors by OCOG Category}

First we will look at the Olympic Games and Olympic Winter Games revenues that were received by the respective OCOGs.

The IOC contribution supports the staging of the Games. This includes direct contribution to the OCOGs (through the share of the television broadcasting rights and TOP rights, support of the OCOG in transfer-of-knowledge activities and expertise to the organisers). From the 2010 Games in Vancouver onwards, the IOC has funded the host broadcaster operations, Olympic Broadcasting Services. These costs were

(C) The Author(s) 2019

$\mathrm{H}$. Preuß et al., Cost and Revenue Overruns of the Olympic

Games 2000-2018, Event- und Impaktforschung,

https://doi.org/10.1007/978-3-658-24996-0_5 
previously borne by the OCOGs. In addition to this funding, the IOC continues to provide a contribution to the operations of the organising committee. Until Beijing, the IOC contribution was paid as a percentage of revenue from the sale of TV rights. That means the amounts can fluctuate very much and depend on for how much money the TV rights were sold. In addition, exchange rates and the rate of inflation affects the amount actually paid. From Vancouver onwards, an absolute amount was fixed before the application phase. This means that this amount was deflated down to the application year. One reason may be that an incorrect estimated inflation rate has been used. Furthermore, the exchange rate is again an influencing factor.

Table 47 Olympic Games estimated and final revenues - IOC contribution

\begin{tabular}{lllllllllll}
\hline $\begin{array}{l}\text { IOC } \\
\text { Contribution }\end{array}$ & $\mathbf{t}-\mathbf{8}$ & $\mathbf{t}-\mathbf{6}$ & $\mathbf{t}-\mathbf{5}$ & $\mathbf{t}-\mathbf{4}$ & $\mathbf{t}-\mathbf{3}$ & $\mathbf{t}-\mathbf{2}$ & $\mathbf{t}-\mathbf{1}$ & final & \\
\hline & & & & & & & & & \\
\hline & Max & $0 \%$ & $-8 \%$ & & & $24 \%$ & $32 \%$ & $32 \%$ & $41 \%$ & SYDNEY \\
\cline { 2 - 10 } & Min & $0 \%$ & & & & & & $-15 \%$ & $-25 \%$ & BEIJING \\
\hline & Max & $0 \%$ & $34 \%$ & & $36 \%$ & $28 \%$ & & & $23 \%$ & SALT LAKE \\
\hline
\end{tabular}

Sources: Athens 2004 Olympic Bid Committee (1996); ATHOC (2003, 2004, 2005a, b); Beijing 2008 Olympic Games Bid Committee (2001); BOCOG (n. d., 2007); COJOPR (2015, 2016a, b); IOC Data; LOCOG (2008, 2009 2012); London 2012 Candidate City (2004); OCA (2002); Rio 2016 Candidate City (2008); Sydney Olympics Bid 2000 (1993); SOCOG (1994, 2001, 2002); POCOG (2014, 2016, 2018); PyeongChang 2018 Olympic \& Paralympic Winter Games Bid Committee (2010); Salt Lake City Bid Committee (1994); SLOC (n. d., 2002); Sochi 2014 Bid Committee (2006); SOOC (2011, 2012, 2013, 2014); Torino Bid Committee (1998); TOROC (2005); Vancouver 2010 Candidate City (2002); VANOC (2007, 2008, 2009, 2014)

SUMMER: The IOC contribution to the hosts of the Olympic Games varies from a maximum revenue overrun in Sydney (41\%) to a revenue underrun in Beijing (-25\%). From Sydney 2000 to Beijing 2008, the OCOGs received an IOC contribution that was dependent on the income from the sale of TV rights. The new regulation, which describes a fixed amount from the signing of the Host City Contract, seems to better assess revenue. This shows that London 2012 and Rio 2016 are not among the extremes. What we observe here is the effect of exchange rates and inflation. It is important to note here that the changes are not based on a better or worse payment from the IOC, but on the economic situation. Nevertheless, we can state that the mean revenues from the IOC contribution produced a revenue overrun of $4 \%$. 
WINTER: The IOC contribution was larger than expected for three Games, though two cities had less. Due to strong inflation, Sochi 2014 received 32\% (in value) less than announced eight years before. This is offset by positive changes, such as in Salt Lake City 2002 with an increase of $23 \%$. Despite this, on average, the host cities received $12 \%$ less IOC contribution for the Olympic Winter Games.

Revenues from TOP rights are partly received in cash, in which case they are recorded in the period the instalments become due, and partly received in the form of goods or services (Value in Kind). Value in Kind is recognised for the USOC, the NOCs and the IOC on a linear basis during the period of the contract. However, for the OCOGs the money is paid only in the year of the Games (IOC 2014, 133).

Table 48 Olympic Games estimated and final revenues - TOP sponsorship

\begin{tabular}{|c|c|c|c|c|c|c|c|c|c|c|}
\hline \multicolumn{2}{|c|}{$\begin{array}{l}\text { TOP } \\
\text { Sponsorship }\end{array}$} & $t-8$ & $t-6$ & $t-5$ & $t-4$ & $t-3$ & $t-2$ & $t-1$ & final & \\
\hline \multirow{3}{*}{$\stackrel{\grave{\Xi}}{\Xi}$} & $\operatorname{Max}$ & $0 \%$ & & & $156 \%$ & $162 \%$ & $154 \%$ & $145 \%$ & $117 \%$ & ATHENS \\
\hline & Mean & $0 \%$ & $-8 \%$ & $-7 \%$ & $46 \%$ & $53 \%$ & $76 \%$ & $60 \%$ & $60 \%$ & \\
\hline & Min & $0 \%$ & & $-7 \%$ & $-5 \%$ & $-5 \%$ & & $8 \%$ & $19 \%$ & LONDON \\
\hline \multirow{3}{*}{ 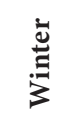 } & $\operatorname{Max}$ & $0 \%$ & $95 \%$ & & $94 \%$ & $57 \%$ & & & $72 \%$ & SALT LAKE \\
\hline & Mean & $0 \%$ & $95 \%$ & & $43 \%$ & $9 \%$ & $-5 \%$ & $25 \%$ & $11 \%$ & \\
\hline & Min & $0 \%$ & & & & $-44 \%$ & $-51 \%$ & $-54 \%$ & $-45 \%$ & SOCHI \\
\hline
\end{tabular}

Sources: Athens 2004 Olympic Bid Committee (1996); ATHOC (2003, 2004, 2005a, b); Beijing 2008 Olympic Games Bid Committee (2001); BOCOG (n. d., 2007); COJOPR (2015, 2016a, b); IOC Data; LOCOG (2008, 2009 2012); London 2012 Candidate City (2004); OCA (2002); Rio 2016 Candidate City (2008); Sydney Olympics Bid 2000 (1993); SOCOG (1994, 2001, 2002); POCOG (2014, 2016, 2018); PyeongChang 2018 Olympic \& Paralympic Winter Games Bid Committee (2010); Salt Lake City Bid Committee (1994); SLOC (n. d., 2002); Sochi 2014 Bid Committee (2006); SOOC (2011, 2012, 2013, 2014); Torino Bid Committee (1998); TOROC (2005); Vancouver 2010 Candidate City (2002); VANOC (2007, 2008, 2009, 2014)

SUMMER: It is easy to see that there has always been a revenue overrun from TOP sponsorship. This illustrates the ongoing success of Olympic marketing. However, in future this revenue source will also be more stable because the IOC now includes the formerly separately paid TOP sponsorship in its IOC contribution. This gives more security to the bid cities, but removes any opportunity to obtain more money or, on the other hand, to lose money. The figure shows that Athens 2004 received almost twice the money than that was planned in its bid book, while London 2012 received only $19 \%$ more. From 2000 to 2016, the five Games average was an additional $60 \%$. 
WINTER: The TOP Programme generated an average $11 \%$ more revenues. The maximum increase in revenue of $72 \%$ was achieved for Salt Lake City 2002 as TOP Partners had signed for higher values in 2002. Sochi 2014 was the only host city with a $45 \%$ revenue underrun (mainly due to currency and inflation impact, which changed the final revenues value).

The OCOGs also raise additional revenue through domestic commercial activities facilitated by the authorised use of the Olympic marks together with the OCOGs' symbols.

Table 49 Olympic Games estimated and final revenues - national sponsorship

\begin{tabular}{|c|c|c|c|c|c|c|c|c|c|c|}
\hline \multicolumn{2}{|c|}{$\begin{array}{l}\text { National } \\
\text { Sponsorship }\end{array}$} & $t-8$ & $t-6$ & $t-5$ & $t-4$ & $t-3$ & $t-2$ & $t-1$ & final & \\
\hline \multirow{3}{*}{ ‡્ } & $\operatorname{Max}$ & $0 \%$ & & & & & & $507 \%$ & $382 \%$ & BEIJING \\
\hline & Mean & $0 \%$ & $-1 \%$ & $36 \%$ & $55 \%$ & $64 \%$ & $67 \%$ & $140 \%$ & $123 \%$ & \\
\hline & Min & $0 \%$ & & & $-15 \%$ & $-1 \%$ & $0 \%$ & $-4 \%$ & $16 \%$ & ATHENS \\
\hline \multirow{3}{*}{ 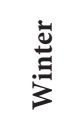 } & Max & $0 \%$ & & & & $97 \%$ & $69 \%$ & $72 \%$ & $76 \%$ & SOCHI \\
\hline & Mean & $0 \%$ & $95 \%$ & & $65 \%$ & $59 \%$ & $47 \%$ & $71 \%$ & $59 \%$ & \\
\hline & Min & $0 \%$ & & & & $42 \%$ & $36 \%$ & $39 \%$ & $30 \%$ & VANCOUVER \\
\hline
\end{tabular}

Sources: Athens 2004 Olympic Bid Committee (1996); ATHOC (2003, 2004, 2005a, b); Beijing 2008 Olympic Games Bid Committee (2001); BOCOG (n. d., 2007); COJOPR (2015, 2016a, b); IOC Data; LOCOG (2008, 2009 2012); London 2012 Candidate City (2004); OCA (2002); Rio 2016 Candidate City (2008); Sydney Olympics Bid 2000 (1993); SOCOG (1994, 2001, 2002); POCOG (2014, 2016, 2018); PyeongChang 2018 Olympic \& Paralympic Winter Games Bid Committee (2010); Salt Lake City Bid Committee (1994); SLOC (n. d., 2002); Sochi 2014 Bid Committee (2006); SOOC (2011, 2012, 2013, 2014); Torino Bid Committee (1998); TOROC (2005); Vancouver 2010 Candidate City (2002); VANOC (2007, 2008, 2009, 2014)

SUMMER: The revenue from the national sponsorship programmes was also a success story for all Olympic Games. The highest increase of revenues was for Beijing 2008. The revenue from national sponsorship increased by $382 \%$. This can be explained by sponsorship by semi-governmental organisations and a higher number of sponsorships. Between t-2 and t-1, Beijing managed to increase the number of sponsorships by 29 (Södermann \& Dolles 2010, 15). Athens, with the lowest revenue overrun, also posted a revenue growth of $16 \%$. The average development of national sponsorship revenues is more than double of what was projected in the candidature files. 
WINTER: Here, all Games have achieved more than projected. Sochi 2014 had the highest revenue overrun of 76\%, while the lowest was Vancouver 2010 with 30\%. Ultimately, on average, about $59 \%$ more was reached by Olympic Winter Games hosts.

An essential component of the income of the organising committees is the sale of tickets.

Table 50 Olympic Games estimated and final revenues - ticket sales

\begin{tabular}{|c|c|c|c|c|c|c|c|c|c|c|}
\hline \multicolumn{2}{|c|}{ Ticket Sales } & $t-8$ & $t-6$ & $t-5$ & $t-4$ & $t-3$ & $t-2$ & $t-1$ & final & \\
\hline \multirow{3}{*}{ 岕 } & Max & $0 \%$ & $-8 \%$ & & & $122 \%$ & $170 \%$ & $173 \%$ & $166 \%$ & SYDNEY \\
\hline & Mean & $0 \%$ & $-8 \%$ & $15 \%$ & $35 \%$ & $36 \%$ & $59 \%$ & $47 \%$ & $63 \%$ & \\
\hline & Min & $0 \%$ & & & & & & $-24 \%$ & $-22 \%$ & BEIJING \\
\hline \multirow{3}{*}{$\stackrel{\stackrel{\leftrightarrows}{\Xi}}{3}$} & Max & $0 \%$ & $44 \%$ & & $18 \%$ & $100 \%$ & & & $112 \%$ & SALT LAKE \\
\hline & Mean & $0 \%$ & $44 \%$ & & $-11 \%$ & $2 \%$ & $-22 \%$ & $-4 \%$ & $32 \%$ & \\
\hline & Min & $0 \%$ & & & & $-37 \%$ & & $-6 \%$ & $-15 \%$ & SOCHI \\
\hline
\end{tabular}

Sources: Athens 2004 Olympic Bid Committee (1996); ATHOC (2003, 2004, 2005a, b); Beijing 2008 Olympic Games Bid Committee (2001); BOCOG (n. d., 2007); COJOPR (2015, 2016a, b); IOC Data; LOCOG (2008, 2009 2012); London 2012 Candidate City (2004); OCA (2002); Rio 2016 Candidate City (2008); Sydney Olympics Bid 2000 (1993); SOCOG (1994, 2001, 2002); POCOG (2014, 2016, 2018); PyeongChang 2018 Olympic \& Paralympic Winter Games Bid Committee (2010); Salt Lake City Bid Committee (1994); SLOC (n. d., 2002); Sochi 2014 Bid Committee (2006); SOOC (2011, 2013, 2014); Torino Bid Committee (1998); Vancouver 2010 Candidate City (2002); VANOC (2007, 2008, 2009, 2014)

SUMMER: Beijing 2008 was the only Olympic Games that generated less from ticket sales than projected during the bid. All other hosts were extremely successful in selling their tickets. Sydney 2000 recorded the highest revenue overrun with $166 \%$. On average, host cities between 2000 and 2016 had an increase of around $63 \%$.

WINTER: Estimating the revenues from ticketing is difficult. Salt Lake City 2002 earned 112\% more revenue than estimated, but PyeongChang 2018 had a loss of $42 \%$. Sochi 2014 also had smaller revenues than expected. On average, about 32\% more revenues were achieved for tickets at the Olympic Winter Games. Factors besides a good or bad estimate that may influence ticket sales are later decisions on the higher capacity of venues, new events staged in the same venues, fewer visitors coming or different ticket prices than calculated before. 
The licensing category includes the sale of merchandise items as well as stamps and coins. Licensing agreements will include a royalty advance and a minimum guarantee. The advance is a non-refundable deposit for the licensing rights, while the guarantee is the minimum amount a licensee will pay, against which royalties may be offset.

Table 51 Olympic Games estimated and final revenues - licensing

\begin{tabular}{llllrrrrrl}
\hline Licensing & $\mathbf{t}-\mathbf{8}$ & $\mathbf{t}-\mathbf{6}$ & $\mathbf{t}-\mathbf{5}$ & $\mathbf{t}-\mathbf{4}$ & $\mathbf{t}-\mathbf{3}$ & $\mathbf{t}-\mathbf{2}$ & $\mathbf{t}-\mathbf{1}$ & $\mathbf{f i n a l}$ & \\
\hline Max & $0 \%$ & & & & & & $26 \%$ & $66 \%$ & BEIJING \\
\hline Mean & $0 \%$ & $-8 \%$ & $11 \%$ & $6 \%$ & $2 \%$ & $3 \%$ & $16 \%$ & $26 \%$ & \\
\hline Min & $0 \%$ & $-8 \%$ & & & $-24 \%$ & $-20 \%$ & $-23 \%$ & $-14 \%$ & SYDNEY \\
\hline Max & $0 \%$ & & & & $3 \%$ & $16 \%$ & $19 \%$ & $25 \%$ & VANCOUVER \\
\hline Mean & $0 \%$ & $8 \%$ & & $-2 \%$ & $17 \%$ & $57 \%$ & $61 \%$ & $-9 \%$ & \\
\hline Min & $0 \%$ & $8 \%$ & & $15 \%$ & $-41 \%$ & & & $-28 \%$ & SALT LAKE \\
\hline
\end{tabular}

Sources: Athens 2004 Olympic Bid Committee (1996); ATHOC (2003, 2004, 2005a, b); Beijing 2008 Olympic Games Bid Committee (2001); BOCOG (n. d., 2007); COJOPR (2015, 2016a, b); IOC Data; LOCOG (2008, 2009 2012); London 2012 Candidate City (2004); OCA (2002); Rio 2016 Candidate City (2008); Sydney Olympics Bid 2000 (1993); SOCOG (1994, 2001, 2002); POCOG (2014, 2016, 2018); PyeongChang 2018 Olympic \& Paralympic Winter Games Bid Committee (2010); Salt Lake City Bid Committee (1994); SLOC (n. d., 2002); Sochi 2014 Bid Committee (2006); SOOC (2011, 2012, 2013, 2014); Torino Bid Committee (1998); TOROC (2005); Vancouver 2010 Candidate City (2002); VANOC (2007, 2008, 2009, 2014)

SUMMER: Revenues from licencing are difficult to predict. It depends on the sales at Games time. Licensing revenues had an average revenue increase of $26 \%$. Beijing 2008 had the highest revenue overrun (66\%) while Sydney 2000 overestimated its revenues. We will see later that Salt Lake City 2002 also generated smaller revenues than expected during the bid. This shows that this category is one of the most difficult to predict.

WINTER: The spectrum of changes is also large. On average, a revenue underrun of $9 \%$ was recorded. The maximum additional revenue was achieved in Vancouver (25\%). Sochi 2014 and Salt Lake City 2002 were unable to reach their initial estimates, with Salt Lake City having revenue underruns of $28 \%$. 
Table 52 Olympic Games estimated and final revenues - lotteries

\begin{tabular}{lccccccccc}
\hline Lotteries & $\mathbf{t}-\mathbf{8}$ & $\mathbf{t}-\mathbf{6}$ & $\mathbf{t}-\mathbf{5}$ & $\mathbf{t}-\mathbf{4}$ & $\mathbf{t}-\mathbf{3}$ & $\mathbf{t}-\mathbf{2}$ & $\mathbf{t}-\mathbf{1}$ & $\mathbf{f i n a l}$ & \\
\hline $\begin{array}{l}\text { Olympic } \\
\text { Games }\end{array}$ & $0 \%$ & & & $21 \%$ & $17 \%$ & $14 \%$ & $10 \%$ & $28 \%$ & ATHENS \\
\hline $\begin{array}{l}\text { Olympic } \\
\text { Winter Games }\end{array}$ & $0 \%$ & & & & $91 \%$ & $75 \%$ & & & SOCHI \\
\hline
\end{tabular}

Sources: Athens 2004 Olympic Bid Committee (1996); ATHOC (2003, 2004, 2005a, b); Beijing 2008 Olympic Games Bid Committee (2001); PyeongChang 2018 Olympic \& Paralympic Winter Games Bid Committee (2010); Sochi 2014 Bid Committee (2006); SOOC (2011, 2012); Torino Bid Committee (1998)

SUMMER: Many Olympic cities cannot use lotteries to fund their OCOG. Only Athens 2004 and Beijing 2008 were host cities that planned revenues from a lottery. Beijing 2008 planned one, but renounced it, or at least we could not find any data. The lottery for Athens 2004 could not be used to finance ATHOC, and the Greek government was obliged to pay these lost revenues.

WINTER: For the Olympic Winter Games, Turin 2006 and PyeongChang 2014 planned a lottery in their Candidature Files, but did not succeed. Only Sochi 2014 wanted to generate revenue through a lottery. Two years prior to the Games it wanted to increase the revenue by $75 \%$, but did not manage to receive revenues in the end.

The donations category is very contextual. This type of revenue could be a type of commitment. E.g. in PyeongChang, the telecom supplier was supposed to build the IBC and use it after the Games. Later the idea was dropped. but the telecom supplier was still bound to provide a subsidy to POCOG. 
Table 53 Olympic Games estimated and final revenues - donations

\begin{tabular}{llllllllll}
\hline Donations & $\mathbf{t}-\mathbf{8}$ & $\mathbf{t}-\mathbf{6}$ & $\mathbf{t}-\mathbf{5}$ & $\mathbf{t}-\mathbf{4}$ & $\mathbf{t}-\mathbf{3}$ & $\mathbf{t}-\mathbf{2}$ & $\mathbf{t}-\mathbf{1}$ & $\mathbf{f i n a l}$ & \\
\hline Max & $0 \%$ & & & & & & $-85 \%$ & $-60 \%$ & BEIJING \\
\hline Mean & $0 \%$ & & $21 \%$ & $17 \%$ & $-43 \%$ & $-65 \%$ & $-80 \%$ & \\
\hline Min & $0 \%$ & & $21 \%$ & $17 \%$ & $-43 \%$ & $-45 \%$ & $-99 \%$ & ATHENS \\
\hline $\begin{array}{l}\text { Oanpic } \\
\text { Winter }\end{array}$ & $0 \%$ & & $3643 \%$ & & & & & \\
Games & & & & & & & & & \\
\hline
\end{tabular}

Sources: Athens 2004 Olympic Bid Committee (1996); ATHOC (2003, 2004, 2005a, b); Beijing 2008 Olympic Games Bid Committee (2001); BOCOG (n. d., 2007); Rio 2016 Candidate City (2008); POCOG (2014, 2016, 2018); PyeongChang 2018 Olympic \& Paralympic Winter Games Bid Committee (2010); Salt Lake City Bid Committee (1994); SLOC (n. d., 2002); Torino Bid Committee (1998); Vancouver 2010 Candidate City (2002)

SUMMER: Donations are also a revenue source that is difficult to predict. Very often we could not find data about donations. Sydney 2000 and London 2012 did not anticipate donations when they created their first budget, and that did not change in the process. By contrast, Rio 2016 expected donations and then apparently could not generate any. Often we had no starting figure (as donations were not anticipated) or we had no final figure. The average is based only on the two cases and shows an $80 \%$ underrun.

WINTER: Here Turin 2006 and Sochi 2018 did not plan revenues. Vancouver 2010 was planning to receive donations when bidding, but did not mention this revenue in the remainder of the preparation progress. The two host cities that received donations averaged more than $1300 \%$. Salt Lake City 2002 had the most revenue overrun, with 2072\%, and followed by PyeongChang 2018with 664\%. However, these high percentages were caused by very low and conservative expectations.

The disposal of assets category is very much linked with the procurement and legacy strategy of the OCOG and the agreements with the government. If the OCOG rents most of its equipment, the disposal value is lower. If the OCOG buys the equipment and afterwards donates it to government entities, the revenue might be lower than expected (e.g. Beijing). The key learning is how early the OCOG incorporates its disposal and legacy strategy in its planning that will allow it to have an appropriate budget plan. 
Table 54 Olympic Games estimated and final revenues - disposal of assets

\begin{tabular}{llllllrrrl}
\hline $\begin{array}{l}\text { Disposal } \\
\text { of Assets }\end{array}$ & $\mathbf{t}-\mathbf{8}$ & $\mathbf{t}-\mathbf{6}$ & $\mathbf{t}-\mathbf{5}$ & $\mathbf{t}-\mathbf{4}$ & $\mathbf{t}-\mathbf{3}$ & $\mathbf{t}-\mathbf{2}$ & $\mathbf{t}-\mathbf{1}$ & \multicolumn{1}{c}{ final } & \\
\hline Max & & & & & & & $0 \%$ & $137 \%$ & SYDNEY \\
\hline Mean & $0 \%$ & & $19 \%$ & $6 \%$ & $-21 \%$ & $175 \%$ & $-44 \%$ & $4 \%$ & \\
\hline Min & $0 \%$ & & & & & & $-88 \%$ & $-73 \%$ & BEIJING \\
\hline Olympic & & & & & & & & & \\
Winter & $0 \%$ & & & & & & & $315 \%$ & SALT LAKE \\
Games & & & & & & & & & \\
\hline
\end{tabular}

Sources: Athens 2004 Olympic Bid Committee (1996); ATHOC (2005a, b); Beijing 2008 Olympic Games Bid Committee (2001); BOCOG (n. d., 2007); COJOPR (2016a, b); IOC Data; LOCOG (2008, 2009 2012); London 2012 Candidate City (2004); OCA (2002); Rio 2016 Candidate City (2008); SOCOG (2001, 2002); POCOG (2014, 2016, 2018); PyeongChang 2018 Olympic \& Paralympic Winter Games Bid Committee (2010); Salt Lake City Bid Committee (1994); SLOC (2002); Sochi 2014 Bid Committee (2006); Torino Bid Committee (1998); TOROC (2005); Vancouver 2010 Candidate City (2002)

SUMMER: Revenues from the disposal of assets are not too difficult to estimate as the average line shows that the final revenues were similar to the bid files. However, Sydney 2000 did not plan revenues until a year before the Games (overrun of 137\%). Beijing 2008, on the other hand, could not reach all the goals it wanted to achieve by selling assets (loss of 73\%).

WINTER: In their candidature files all hosts of the Olympic Winter Games wanted to generate revenues from the disposal of assets. In the end, only Salt Lake City 2002 included them in their revenue structure. The others may have taken it in "others". Salt Lake City 2002 had a revenue overrun of about 315\%. 
Table 55 Olympic Games estimated and final revenues - subsidies

\begin{tabular}{|c|c|c|c|c|c|c|c|c|c|}
\hline Subsidies & $t-8$ & $t-6$ & $t-5$ & $t-4$ & $t-3$ & $t-2$ & $t-1$ & final & \\
\hline \multirow{3}{*}{ 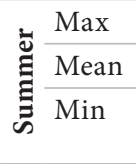 } & $0 \%$ & & $48 \%$ & $47 \%$ & $48 \%$ & & $106 \%$ & $143 \%$ & LONDON \\
\hline & $0 \%$ & & $48 \%$ & $20 \%$ & $48 \%$ & & $106 \%$ & $48 \%$ & \\
\hline & & & & & & & & $0 \%$ & $\begin{array}{l}\text { SYDNEY/ } \\
\text { ATHENS }\end{array}$ \\
\hline$\doteq \operatorname{Max}$ & $0 \%$ & & & $0 \%$ & & & & $1540 \%$ & SALT LAKE \\
\hline$\vec{J}$ Mean & $0 \%$ & & & $47 \%$ & $19 \%$ & $45 \%$ & $-44 \%$ & $593 \%$ & \\
\hline$>\operatorname{Min}$ & $0 \%$ & & & & $-59 \%$ & $-57 \%$ & $-44 \%$ & $-42 \%$ & SOCHI \\
\hline
\end{tabular}

Sources: Athens 2004 Olympic Bid Committee (1996); ATHOC (2005b); Beijing 2008 Olympic Games Bid Committee (2001); COJOPR (2016a); IOC Data; LOCOG (2008, 2009 2012); London 2012 Candidate City (2004); OCA (2002); Rio 2016 Candidate City (2008); Sydney Olympics Bid 2000 (1993); SOCOG (2002); POCOG (2014, 2016, 2018); PyeongChang 2018 Olympic \& Paralympic Winter Games Bid Committee (2010); Salt Lake City Bid Committee (1994); SLOC (n. d., 2002); Sochi 2014 Bid Committee (2006); SOOC (2011, 2012, 2013, 2014); Torino Bid Committee (1998); TOROC (2005); Vancouver 2010 Candidate City (2002); VANOC (2014)

SUMMER: Sydney 2000 and Athens 2004 did not expect to receive subsidies from the state, region or city. In the end, their budgets showed subsidies. By contrast, Beijing $2008^{21}$ and Rio $2016^{22}$ were planning to obtain subsidies, but they did not receive them. Only London 2012 had consistent recourse to subsidies, which eventually overran by $143 \%$. London's high subsidy revenue overrun explains the high average of $48 \%$ for the Olympic Games.

WINTER: All Olympic Winter Games OCOGs expected subsidies according to their candidature files. Turin 2006 did not get them. Sochi 2014 had a $42 \%$ revenue underrun, while the other cities had a revenue overrun. On average, subsidies led to a 593\% revenue overrun, with Salt Lake City 2002 having the highest $(1540 \%)$ due to low and conservative expectations.

21 Beijing 2008 had a successful commercial programme, so it did not use the government subsidies.

22 Rio 2016 tried to avoid the subsidies in order to maintain its private entity legal status. 
Table 56 Olympic Games estimated and final revenues - total

\begin{tabular}{llcccccccc}
\hline Total & $\mathbf{t}-\mathbf{8}$ & $\mathbf{t}-\mathbf{6}$ & $\mathbf{t}-\mathbf{5}$ & $\mathbf{t}-\mathbf{4}$ & $\mathbf{t}-\mathbf{3}$ & $\mathbf{t}-\mathbf{2}$ & $\mathbf{t}-\mathbf{1}$ & $\mathbf{f i n a l}$ & \\
\hline Max & $0 \%$ & $-8 \%$ & & & $52 \%$ & $67 \%$ & $63 \%$ & $72 \%$ & SYDNEY \\
\hline Mean & $0 \%$ & $-8 \%$ & $26 \%$ & $27 \%$ & $25 \%$ & $31 \%$ & $34 \%$ & $45 \%$ & \\
\hline Min & $0 \%$ & & & & & & $25 \%$ & $8 \%$ & BEIJING \\
\hline Max & $0 \%$ & $51 \%$ & & $110 \%$ & $96 \%$ & & & $119 \%$ & SALT LAKE \\
\hline Mean & $0 \%$ & $51 \%$ & & $65 \%$ & $31 \%$ & $9 \%$ & $18 \%$ & $43 \%$ & \\
\hline Min & $0 \%$ & & & & $-5 \%$ & $-9 \%$ & $-7 \%$ & $-3 \%$ & SOCHI \\
\hline
\end{tabular}

Sources: Athens 2004 Olympic Bid Committee (1996); ATHOC (2003, 2004, 2005a, b); Beijing 2008 Olympic Games Bid Committee (2001); BOCOG (n. d., 2007); COJOPR (2015, 2016a, b); IOC Data; LOCOG (2008, 2009, 2012); London 2012 Candidate City (2004); OCA (2002); Sydney Olympics Bid (1993); Rio 2016 Candidate City (2008); SOCOG (2001, 2002); POCOG (2014, 2016, 2018); PyeongChang 2018 Olympic \& Paralympic Winter Games Bid Committee (2010); Salt Lake City Bid Committee (1994); SLOC (n. d., 2002); Sochi 2014 Bid Committee (2006); SOOC (2011, 2012, 2013, 2014); Torino Bid Committee (1998); TOROC (2005); Vancouver 2010 Candidate City (2002); VANOC (2007, 2008, 2009, 2014)

SUMMER: When considering total revenues, all OCOGs achieved a revenue overrun over the eight years of preparation. The expectations of the cities were greatly exceeded. Sydney 2000 had the highest gain of $72 \%$, while the average overrun was about $45 \%$.

WINTER: For the Winter Games, all OCOGs but Sochi 2014 received more revenues than planned in their candidature files. On average, they were able to generate an additional 43\%. The highest revenue overrun was Salt Lake City 2002 with 119\%, and the only revenue underrun was for Sochi 2014 with 11\%. This was mainly caused by a high inflation rate and the exchange rate to the USD. 


\subsection{Expenditure Corridors by OCOG Category}

In the following section we will look at the corridors that can be seen in OCOG expenditure categories.

Table 57 Olympic Games estimated and final expenditures - venues

\begin{tabular}{llllllrrrl}
\hline Venues & $\mathbf{t}-\mathbf{8}$ & $\mathbf{t}-\mathbf{6}$ & $\mathbf{t}-\mathbf{5}$ & $\mathbf{t}-\mathbf{4}$ & $\mathbf{t}-\mathbf{3}$ & $\mathbf{t}-\mathbf{2}$ & $\mathbf{t}-\mathbf{1}$ & final & \\
\hline Max & $0 \%$ & $-8 \%$ & & & $89 \%$ & $181 \%$ & $163 \%$ & $203 \%$ & SYDNEY \\
\hline Mean & $0 \%$ & $-8 \%$ & $22 \%$ & $-19 \%$ & $-13 \%$ & $32 \%$ & $6 \%$ & $40 \%$ & \\
\hline Min & $0 \%$ & & & & & & $-78 \%$ & $-54 \%$ & BEIJING \\
\hline Max & $0 \%$ & & & & $-41 \%$ & $-46 \%$ & $-36 \%$ & $-33 \%$ & SOCHI \\
\hline Mean & $0 \%$ & & & $-3 \%$ & $-10 \%$ & $-1 \%$ & $-43 \%$ & $-52 \%$ & \\
\hline Min & $0 \%$ & & & & & & $-49 \%$ & $-81 \%$ & TURIN \\
\hline
\end{tabular}

Sources: Athens 2004 Olympic Bid Committee (1996); ATHOC (2003, 2004, 2005a, b); Beijing 2008 Olympic Games Bid Committee (2001); BOCOG (n. d., 2007); COJOPR (2015, 2016a, b); LOCOG (2008, 2009, 2012, 2013); London 2012 Candidate City (2004); OCA (2002); Rio 2016 Candidate City (2008); Sydney Olympics Bid (1993); SOCOG (2001, 2002); POCOG (2014, 2016, 2018); PyeongChang 2018 Olympic \& Paralympic Winter Games Bid Committee (2010); SLOC (1998); Sochi 2014 Bid Committee (2006); SOOC (2011, 2012, 2013, 2014); Torino Bid Committee (1998); TOROC (n. d., 2005); Vancouver 2010 Candidate City (2002); VANOC (2008)

The expenditures for venues show both cost overruns and cost underruns. For the operational expenditures and capital investments of facilities, Sydney 2000 had an overrun of $203 \%$. However, on average, expenditure on venues tends to have cost underruns. Athens 2004, Beijing 2008 and Rio 2016 reduced their costs during the preparations. This is also the result of the agreements concerning the split of responsibilities between the OCOG and government parties. One element is the ongoing optimisation of requirements, but another element is that some responsibilities are shifted to the government. Nevertheless, the average increase in expenditures over the eight years was around $40 \%$ for Olympic Games but minus $52 \%$ for Winter Games.

WINTER: All Winter Games OCOGs, except PyeongChang 2018 which is not finished yet, finally spent less than they had originally expected. Turin 2006 spent $81 \%$ less than planned. 
Table 58 Olympic Games estimated and final expenditures - workforce ${ }^{23}$

\begin{tabular}{lllrrrrrrl}
\hline Workforce & $\mathbf{t}-\mathbf{8}$ & $\mathbf{t}-\mathbf{6}$ & $\mathbf{t}-\mathbf{5}$ & $\mathbf{t}-\mathbf{4}$ & $\mathbf{t}-\mathbf{3}$ & $\mathbf{t}-\mathbf{2}$ & $\mathbf{t}-\mathbf{1}$ & $\mathbf{f i n a l}$ & \\
\hline Max & & & & $0 \%$ & $200 \%$ & $82 \%$ & & $179 \%$ & ATHENS \\
\hline Mean & $0 \%$ & $-8 \%$ & $154 \%$ & $15 \%$ & $121 \%$ & $23 \%$ & $-23 \%$ & $30 \%$ & \\
\hline Min & & & & & & & $0 \%$ & $-37 \%$ & BEIJING \\
\hline Max & & & & $0 \%$ & & & & $702 \%$ & SALT LAKE \\
\hline Mean & $0 \%$ & & & $32 \%$ & $11 \%$ & $-9 \%$ & $3 \%$ & $283 \%$ & \\
\hline Min & $0 \%$ & & & & $17 \%$ & $7 \%$ & $6 \%$ & $1 \%$ & SOCHI \\
\hline
\end{tabular}

Sources: ATHOC (2003, 2004, 2005a, b); BOCOG (n. d., 2007); COJOPR (2015, 2016a, b); LOCOG (2008, 2009, 2012, 2013); London 2012 Candidate City (2004); OCA (2002); Rio 2016 Candidate City (2008); Sydney Olympics Bid (1993); SOCOG (2001, 2002); POCOG (2014, 2016, 2018); PyeongChang 2018 Olympic \& Paralympic Winter Games Bid Committee (2010); SLOC (1998); Sochi 2014 Bid Committee (2006); SOOC (2011, 2012, 2013, 2014); Torino Bid Committee (1998); TOROC (n. d., 2005); Vancouver 2010 Candidate City (2002); VANOC (2008)

SUMMER: The figure on the left shows that, on average, the changes are great, but tend to be at $30 \%$ for the last two years. Athens 2004 had the highest expenditure increase, and started to calculate those only four years before the Games. The other host cities had moderate changes. Beijing 2008, for example, did not report the costs of the workforce separately until a year before the Games and then even underran that projection. BOCOG also didn't include all government staff in the workforce budget. Sydney 2000 and London 2012 also cut costs for the workforce.

WINTER: For the Olympic Winter Games, the changes are not as great. However, Salt Lake City 2002 did not show its workforce costs exploding in its Candidature File, which is why the first record was only four years before the Games were staged, and then the estimate was exceeded by $702 \%$. Sochi 2014 , on the other hand, only had a slight increase of 1\%. The cost overruns of Turin 2006 had a moderate $10 \%$ overrun. The five Games average, however, had a $283 \%$ overrun caused by Salt Lake City 2002.

23 The "workforce" category was presented inconsistently for the different Games editions. Some centralised those costs, whereas others decentralised them. As a result, there are strong fluctuations between the results. 
Table 59 Olympic Games estimated and final expenditures - technology

\begin{tabular}{llrrrrrrrl}
\hline Technology & $\mathbf{t}-\mathbf{8}$ & $\mathbf{t}-\mathbf{6}$ & $\mathbf{t}-\mathbf{5}$ & $\mathbf{t}-\mathbf{4}$ & $\mathbf{t}-\mathbf{3}$ & $\mathbf{t}-\mathbf{2}$ & $\mathbf{t}-\mathbf{1}$ & final & \\
\hline Max & $0 \%$ & & $-5 \%$ & $30 \%$ & $57 \%$ & & $60 \%$ & $72 \%$ & LONDON \\
\hline Mean & $0 \%$ & & $-5 \%$ & $15 \%$ & $11 \%$ & $1 \%$ & $17 \%$ & $16 \%$ & \\
\hline Min & & & & $0 \%$ & $4 \%$ & $-9 \%$ & $-12 \%$ & $-21 \%$ & ATHENS \\
\hline Max & $0 \%$ & & & & & & $145 \%$ & $277 \%$ & TURIN \\
\hline Mean & $0 \%$ & & & $3 \%$ & $5 \%$ & $4 \%$ & $53 \%$ & $72 \%$ & \\
\hline Min & & & & $0 \%$ & & & & $-22 \%$ & SALT LAKE \\
\hline
\end{tabular}

Sources: ATHOC (2003, 2004, 2005a, b); BOCOG (n. d., 2007); COJOPR (2015, 2016a, b); LOCOG (2008, 2009, 2012, 2013); London 2012 Candidate City (2004); OCA (2002); Rio 2016 Candidate City (2008); Sydney Olympics Bid (1993); SOCOG (2001, 2002); POCOG (2014, 2016, 2018); PyeongChang 2018 Olympic \& Paralympic Winter Games Bid Committee (2010); SLOC (1998); Sochi 2014 Bid Committee (2006); SOOC (2011, 2012, 2013, 2014); Torino Bid Committee (1998); TOROC (n. d., 2005); Vancouver 2010 Candidate City (2002); VANOC $(2007,2008,2009,2014)$

SUMMER: The development of the expenditures for technology is moderate. In addition to London 2012, which had the highest expenditure increase of $72 \%$, Sydney 2000 also had higher expenditures for technology. The other three cities had cost underruns. It should also be noted that technology costs are not as volatile as other categories. The IOC provides financial info about the key TOP technology partners like OMEGA and Atos because former bid cities used to completely miss out the cost of the key technology components. Apparently, these expenses can be estimated comparatively well. This is also evident from the only slight average cost increase of $16 \%$.

WINTER: Technology for the Olympic Winter Games was 72\% higher on average. Three OCOGs spent more than expected, but two were able to even save in this category. The highest overrun was for Turin 2006 (277\%), while Salt Lake City 2002 optimise its spending by $22 \%$. 
Table 60 Olympic Games estimated and final expenditures - services

\begin{tabular}{lllllrrrrl}
\hline Services & $\mathbf{t}-\mathbf{8}$ & $\mathbf{t}-\mathbf{6}$ & $\mathbf{t}-\mathbf{5}$ & $\mathbf{t}-\mathbf{4}$ & $\mathbf{t}-\mathbf{3}$ & $\mathbf{t}-\mathbf{2}$ & $\mathbf{t}-\mathbf{1}$ & \multicolumn{1}{l}{ final } & \\
\hline Max & $0 \%$ & $-8 \%$ & & & $240 \%$ & $301 \%$ & $305 \%$ & $103 \%$ & SYDNEY \\
\hline Mean & $0 \%$ & $-8 \%$ & $24 \%$ & $11 \%$ & $45 \%$ & $81 \%$ & $60 \%$ & $46 \%$ & \\
\hline Min & $0 \%$ & & & & & & $-14 \%$ & $9 \%$ & BEIJING \\
\hline Max & $0 \%$ & & & $-17 \%$ & & & & $712 \%$ & SALT LAKE \\
\hline Mean & $0 \%$ & & & $-14 \%$ & $-13 \%$ & $40 \%$ & $19 \%$ & $294 \%$ & \\
\hline Min & $0 \%$ & & & & $-20 \%$ & $-28 \%$ & $-19 \%$ & $-23 \%$ & SOCHI \\
\hline
\end{tabular}

Sources: Athens 2004 Olympic Bid Committee (1996); ATHOC (2003, 2004, 2005a, b); Beijing 2008 Olympic Games Bid Committee (2001); BOCOG (n. d., 2007); COJOPR (2015, 2016a, b); LOCOG (2008, 2009, 2012, 2013); London 2012 Candidate City (2004); OCA (2002); Rio 2016 Candidate City (2008); Sydney Olympics Bid (1993); SOCOG (2001, 2002); POCOG (2014, 2016, 2018); PyeongChang 2018 Olympic \& Paralympic Winter Games Bid Committee (2010); Salt Lake City Bid Committee (1994); SLOC (1998); Sochi 2014 Bid Committee (2006); SOOC (2011, 2012, 2013, 2014); Torino Bid Committee (1998); TOROC (n. d.); Vancouver 2010 Candidate City (2002); VANOC (2008)

SUMMER: For services, the mean expenditure increase was about $46 \%$. It should be noted that all OCOGs spent more on services than they originally planned. Sydney 2000 even spent twice as much as planned. In fact, a year before the Games, it had even planned four times higher expenditures. Beijing 2008 had the lowest cost increase with only $9 \%$.

WINTER: Expenditures for services also became more expensive for all Olympic Winter Games, except for Sochi 2014 (minus 23\%). A reason may be that location and market maturity has an impact on costs. The average change was much higher here, with 294\%. The highest expenditure increase was for Salt Lake City 2002, with $712 \%$.

In the marketing \& events category, the ceremonies and torch relay are also assumed, which are key fundamentals of accounting at the Olympic Games, under the responsibility of the OCOG, which makes a strategic decision on how much it wants to spend. 
Table 61 Olympic Games estimated and final expenditures - marketing \& events

\begin{tabular}{llllllllll}
\hline $\begin{array}{l}\text { Marketing \& } \\
\text { Events }\end{array}$ & $\mathbf{t}-\mathbf{8}$ & $\mathbf{t}-\mathbf{6}$ & $\mathbf{t}-\mathbf{5}$ & $\mathbf{t}-\mathbf{4}$ & $\mathbf{t}-\mathbf{3}$ & $\mathbf{t}-\mathbf{2}$ & $\mathbf{t}-1$ & final & \\
\hline Max & $0 \%$ & & $11 \%$ & $38 \%$ & $-6 \%$ & & $209 \%$ & $78 \%$ & LONDON \\
\hline Mean & $0 \%$ & $-8 \%$ & $11 \%$ & $22 \%$ & $-7 \%$ & $-11 \%$ & $80 \%$ & $32 \%$ & \\
\hline Min & $0 \%$ & $-8 \%$ & & & $-48 \%$ & $-55 \%$ & $-59 \%$ & $-46 \%$ & SYDNEY \\
\hline Max & $0 \%$ & & & & $354 \%$ & $53 \%$ & $381 \%$ & $437 \%$ & VANCOUVER \\
\hline Mean & $0 \%$ & & & $27 \%$ & $134 \%$ & $42 \%$ & $148 \%$ & $126 \%$ & \\
\hline Min & $0 \%$ & & & $19 \%$ & & & & $-23 \%$ & SALT LAKE \\
\hline
\end{tabular}

Sources: Athens 2004 Olympic Bid Committee (1996); ATHOC (2003, 2004, 2005a, b); Beijing 2008 Olympic Games Bid Committee (2001); BOCOG (n. d., 2007); COJOPR (2015, 2016a, b); LOCOG (2008, 2009, 2012, 2013); London 2012 Candidate City (2004); OCA (2002); Rio 2016 Candidate City (2008); Sydney Olympics Bid (1993); SOCOG (2001, 2002); POCOG (2014, 2016, 2018); PyeongChang 2018 Olympic \& Paralympic Winter Games Bid Committee (2010); Salt Lake City Bid Committee (1994); SLOC (1998); Sochi 2014 Bid Committee (2006); SOOC (2011, 2012, 2013, 2014); Torino Bid Committee (1998); TOROC (n. d., 2005); Vancouver 2010 Candidate City (2002); VANOC (2007, 2008, 2009, 2014)

SUMMER: There is quite a lot of variation in the marketing \& events category. Sydney 2000 cut expenditures in this category by 46\%. Athens 2004, Beijing 2008 and London 2012, on the other hand, spent more than they had indicated in their application documents. In 2011, London 2012 had a threefold expenditure overrun, but finally achieved $78 \%$. For marketing \& events, the average increase was $32 \%$. This is easy to explain because many marketing activities and the torch relay are often only planned well after winning a bid.

WINTER: Vancouver 2010 had cost overruns of $437 \%$ in the final budget. Apart from Sochi 2014 (minus 23\%), all other cities had overruns, the average being 126\%. In general, American cities have less marketing operation costs because they are in joint venture with the United States Olympic Committee. 
Table 62 Olympic Games estimated and final expenditures - administration \& coordination

\begin{tabular}{|c|c|c|c|c|c|c|c|c|c|c|}
\hline \multicolumn{2}{|c|}{$\begin{array}{l}\text { Administration } \\
\text { \& Coordination }\end{array}$} & $t-8$ & $t-6$ & $t-5$ & $t-4$ & $t-3$ & $t-2$ & $t-1$ & final & \\
\hline \multirow{3}{*}{ 离 } & $\operatorname{Max}$ & $0 \%$ & $-8 \%$ & & & $343 \%$ & $294 \%$ & $253 \%$ & $481 \%$ & SYDNEY \\
\hline & Mean & $0 \%$ & $-8 \%$ & $33 \%$ & $11 \%$ & $96 \%$ & $144 \%$ & $95 \%$ & $153 \%$ & \\
\hline & Min & $0 \%$ & & & & & & $25 \%$ & $19 \%$ & BEIJING \\
\hline \multirow{3}{*}{$\stackrel{\stackrel{ \pm}{\Xi}}{3}$} & Max & $0 \%$ & & & & $-13 \%$ & $-16 \%$ & $-19 \%$ & $-10 \%$ & SOCHI \\
\hline & Mean & $0 \%$ & & & $21 \%$ & $9 \%$ & $22 \%$ & $-23 \%$ & $-29 \%$ & \\
\hline & Min & $0 \%$ & & & $-9 \%$ & & & & $-51 \%$ & SALT LAKE \\
\hline
\end{tabular}

Sources: Athens 2004 Olympic Bid Committee (1996); ATHOC (2003, 2004, 2005a, b); Beijing 2008 Olympic Games Bid Committee (2001); BOCOG (n. d., 2007); COJOPR (2015, 2016a, b); LOCOG (2008, 2009, 2012, 2013); London 2012 Candidate City (2004); OCA (2002); Rio 2016 Candidate City (2008); Sydney Olympics Bid (1993); SOCOG (2001, 2002); POCOG (2014, 2016, 2018); PyeongChang 2018 Olympic \& Paralympic Winter Games Bid Committee (2010); Salt Lake City Bid Committee (1994); SLOC (1998); Sochi 2014 Bid Committee (2006); SOOC (2011, 2012, 2013, 2014); Torino Bid Committee (1998); TOROC (n. d.); Vancouver 2010 Candidate City (2002); VANOC (2007, 2008, 2009, 2014)

SUMMER: Administration and coordination expenses were also higher than planned for all Games. On average, OCOGs spent 153\% more, with Sydney 2000 reaching a $481 \%$ expenditure overrun. That leads to the relatively high average figure of $70 \%$. The lowest cost increase was Beijing 2008 with 19\%.

WINTER: Unlike the Olympic Games, the Olympic Winter Games seem to be better planned and controlled in this category. All cities had cost underruns. The average cost reduction was $29 \%$. 
Table 63 Olympic Games estimated and final expenditures - total

\begin{tabular}{llllllllll}
\hline Total & $\mathbf{t}-\mathbf{8}$ & $\mathbf{t}-\mathbf{6}$ & $\mathbf{t}-\mathbf{5}$ & $\mathbf{t}-\mathbf{4}$ & $\mathbf{t}-\mathbf{3}$ & $\mathbf{t}-\mathbf{2}$ & $\mathbf{t}-\mathbf{1}$ & \multicolumn{1}{c}{ final } & \\
\hline Max & $0 \%$ & $-8 \%$ & & & $53 \%$ & $66 \%$ & $63 \%$ & $51 \%$ & SYDNEY \\
\hline Mean & $0 \%$ & $-8 \%$ & $26 \%$ & $27 \%$ & $27 \%$ & $36 \%$ & $31 \%$ & $33 \%$ & \\
\hline Min & $0 \%$ & & & & & & $25 \%$ & $4 \%$ & BEIJING \\
\hline Max & $0 \%$ & & & $70 \%$ & & & & $114 \%$ & SALT LAKE \\
\hline Mean & $0 \%$ & & & $45 \%$ & $10 \%$ & $16 \%$ & $18 \%$ & $45 \%$ & \\
\hline Min & $0 \%$ & & & & $-5 \%$ & $-9 \%$ & $-7 \%$ & $-6 \%$ & SOCHI \\
\hline
\end{tabular}

Sources: Athens 2004 Olympic Bid Committee (1996); ATHOC (2003, 2004, 2005a, b); Beijing 2008 Olympic Games Bid Committee (2001); BOCOG (n. d., 2007); COJOPR (2015, 2016a, b); LOCOG (2008, 2009, 2012, 2013); London 2012 Candidate City (2004); OCA (2002); Rio 2016 Candidate City (2008); Sydney Olympics Bid (1993); SOCOG (2001, 2002); POCOG (2014, 2016, 2018); PyeongChang 2018 Olympic \& Paralympic Winter Games Bid Committee (2010); Salt Lake City Bid Committee (1994); SLOC (1998); Sochi 2014 Bid Committee (2006); SOOC (2011, 2012, 2013, 2014); Torino Bid Committee (1998); TOROC (n. d., 2005); Vancouver 2010 Candidate City (2002); VANOC (2007, 2008, 2009, 2014)

For four out of five of the last Olympic Games we observed expenditure overruns. The five Games average was 33\%, with the maximum overrun of 51\% for Sydney 2000. The five Games average for Winter Games was about $45 \%$. Salt Lake City 2002 had the biggest changes (114\%), but Sochi 2014 only $-6 \%$.

\subsection{Non-OCOG Cost Corridors at Olympic Games}

The following section will provide the cost changes for different venues. We will look at the venues in our "basket" but differentiate between the Olympic Games and Olympic Winter Games because the size of the venues and the venues themselves are different. 
Table 64 Olympic Games estimated and final non-OCOG costs - Olympic Stadium

\begin{tabular}{lllllrrrrr}
\hline $\begin{array}{l}\text { Olympic } \\
\text { Stadium }\end{array}$ & $\mathbf{t}-\mathbf{8}$ & $\mathbf{t}-\mathbf{6}$ & $\mathbf{t}-\mathbf{5}$ & $\mathbf{t}-\mathbf{4}$ & $\mathbf{t}-\mathbf{3}$ & $\mathbf{t}-\mathbf{2}$ & $\mathbf{t}-\mathbf{1}$ & final & \\
\hline Max & $0 \%$ & $67 \%$ & & & & $79 \%$ & $44 \%$ & $40 \%$ & LONDON \\
\hline Mean & $0 \%$ & $67 \%$ & & & & $10 \%$ & $-9 \%$ & $-11 \%$ & \\
\hline Min & $0 \%$ & & & & & $-60 \%$ & $-62 \%$ & $-61 \%$ & SYDNEY \\
\hline
\end{tabular}

Sources: Camara dos Deputados (2017); DCMS (2012a, b); House of Commons (2010); London 2012 Candidate City (2004); NSW (2002); OCA (1999, 2002); Rio 2016 Candidate City (2008); Sydney Olympics 2000 Bid Limited (1993); The Audit Office (1999, 2002)

Many media reports say it is surprising that the costs (governmental share) for the Olympic stadiums were on average $11 \%$ lower than announced in the candidature files. However, what may have an influence here is that we found only three cities where the costs were properly estimated in the candidature. However, a generalisation is not possible from this because Athens 2004 and Beijing 2008 had cost overruns which are not displayed transparently enough.

Based on solid facts and considering inflation we can state that Sydney 2000 had lower costs by $61 \%$. London 2012 spent $40 \%$ more for the construction of its Olympic Stadium.

Table 65 Olympic Games estimated and final non-OCOG costs - swimming pool

\begin{tabular}{|c|c|c|c|c|c|c|c|c|c|}
\hline Swimming Pool & $t-8$ & $t-6$ & $t-5$ & $t-4$ & $t-3$ & $t-2$ & $t-1$ & final & \\
\hline $\operatorname{Max}$ & $0 \%$ & $178 \%$ & & & & $242 \%$ & $225 \%$ & $216 \%$ & LONDON \\
\hline Mean & $0 \%$ & $178 \%$ & & & & $121 \%$ & $225 \%$ & $105 \%$ & ( 2 cities $)$ \\
\hline Min & & & & & & $0 \%$ & & $-6 \%$ & SYDNEY \\
\hline
\end{tabular}

Sources: Camara dos Deputados (2017); DCMS (2012a, b); House of Commons (2010); Kao (2016); London 2012 Candidate City (2004); NSW (2002); OCA (1999, 2002); Rio 2016 Candidate City (2008); The Audit Office $(1999,2002)$

For the construction of swimming pools, we also gathered reliable data only from three Games. Regarding the public investments in this venue, London 2012 had the highest increase (216\%), while Sydney 2000 constructed its pool even cheaper than its projection two years before the Games. On average, the construction of a swimming pool is $105 \%$ more expensive than planned. 
Table 66 Olympic Games estimated and final non-OCOG costs - multipurpose hall

\begin{tabular}{lccccccccc}
\hline Multipurpose Hall & $\mathbf{t}-\mathbf{8}$ & $\mathbf{t}-\mathbf{6}$ & $\mathbf{t}-\mathbf{5}$ & $\mathbf{t}-\mathbf{4}$ & $\mathbf{t}-\mathbf{3}$ & $\mathbf{t}-\mathbf{2}$ & $\mathbf{t}-\mathbf{1}$ & final & \\
\hline Max & $0 \%$ & & & & & $106 \%$ & $81 \%$ & $75 \%$ & SYDNEY \\
\hline Mean & $0 \%$ & $120 \%$ & & & $106 \%$ & $66 \%$ & $61 \%$ & \\
\hline Min & $0 \%$ & $120 \%$ & & & & $50 \%$ & $47 \%$ & LONDON \\
\hline
\end{tabular}

Sources: DCMS (2012a, b); London 2012 Candidate City (2004); NSW (2002); OCA (1999, 2002); Sydney Olympics 2000 Bid Limited (1993); The Audit Office $(1999,2002)$

The multipurpose hall is usually the main Olympic facility. We could find valid data for two Games only. Thus the average here is a $61 \%$ cost overrun calculated from Sydney (75\%) and London (47\%).

Table 67 Olympic Games estimated and final non-OCOG costs - velodrome

\begin{tabular}{|c|c|c|c|c|c|c|c|c|c|}
\hline Velodrome & $t-8$ & $t-6$ & $t-5$ & $t-4$ & $t-3$ & $t-2$ & $t-1$ & final & \\
\hline Max & $0 \%$ & & & & & $563 \%$ & $539 \%$ & $535 \%$ & SYDNEY \\
\hline Mean & $0 \%$ & $138 \%$ & & & & $391 \%$ & $360 \%$ & $359 \%$ & (2 cities) \\
\hline Min & $0 \%$ & $138 \%$ & & & & $218 \%$ & $181 \%$ & $182 \%$ & LONDON \\
\hline
\end{tabular}

Sources: Camara dos Deputados (2017); DCMS (2012a, b); House of Commons (2010); Kao (2016); London 2012 Candidate City (2004); NSW (2002); OCA (1999, 2002); Rio 2016 Candidate City (2008); Sydney Olympics 2000 Bid Limited (1993); The Audit Office (1999, 2002)

In the three reliable data sets, we found an average cost overrun of $359 \%$ for the velodrome. In all host cities, the costs were higher than originally planned, in Sydney 2000 more than six fold and London 2012 182\%.

Table 68 Olympic Games estimated and final non-OCOG costs - Olympic Village

\begin{tabular}{|c|c|c|c|c|c|c|c|c|c|}
\hline Olympic Village & $t-8$ & $t-6$ & $t-5$ & $t-4$ & $t-3$ & $t-2$ & $t-1$ & final & \\
\hline $\operatorname{Max}$ & $0 \%$ & & & & & $127 \%$ & & $157 \%$ & SYDNEY \\
\hline Mean & $0 \%$ & & & & & $127 \%$ & $1 \%$ & $45 \%$ & \\
\hline Min & $0 \%$ & & & & & & & $-27 \%$ & ATHENS \\
\hline
\end{tabular}

Sources: Athens 2004 Olympic Bid Committee (1996); Camara dos Deputados (2017); DCMS (2012a, b); Kasimati (2015); London 2012 Candidate City (2004); NSW (2002); OCA (2002); Rio 2016 Candidate City (2008); Sydney Olympics 2000 Bid Limited (1993); The Audit Office $(1999,2002)$ 
The only host that built the Olympic Village cheaper than planned was Athens 2004 (minus 27\%). All others had cost overruns with an average of $45 \%$. The highest cost overrun was in Sydney 2000 at $157 \%$.

For the IBC/MPC, we had data only from London 2012, which had a cost overrun of $103 \%$.

Table 69 Olympic Games estimated and final non-OCOG costs - total

\begin{tabular}{llllllllll}
\hline Total & $\mathbf{t}-\mathbf{8}$ & $\mathbf{t}-\mathbf{6}$ & $\mathbf{t}-\mathbf{5}$ & $\mathbf{t}-\mathbf{4}$ & $\mathbf{t}-\mathbf{3}$ & $\mathbf{t}-\mathbf{2}$ & $\mathbf{t}-\mathbf{1}$ & final & \\
\hline Max & $0 \%$ & & & & & $43 \%$ & & $56 \%$ & SYDNEY \\
\hline Mean & $0 \%$ & $85 \%$ & & & & $82 \%$ & $42 \%$ & $50 \%$ & \\
\hline Min & $0 \%$ & $85 \%$ & & & & $120 \%$ & $42 \%$ & $43 \%$ & LONDON \\
\hline
\end{tabular}

Sources: Camara dos Deputados (2017); DCMS (2012a, b); House of Commons (2010); Kasimati (2015); London 2012 Candidate City (2004); NSW (2002); OCA (1999, 2002); Rio 2016 Candidate City (2008); Sydney Olympics 2000 Bid Limited (1993); The Audit Office (1999, 2002)

The overall cost overruns were calculated as an average of the available data. Two out of two ${ }^{24}$ host cities had cost overruns. Sydney 2000, with 56\%, had the highest overrun, London actually spent $43 \%$ more than planned. Finally, it can be stated that the construction of sports facilities is about $50 \%$ higher than indicated in the candidature file.

24 We weren't able to find data for Beijing 2008 and had to use different venues for Athens 2004 because nearly all of our elected venues had no capital investments at the stage of the Candidature File. Similarly, as there is no final budget yet for the Games in Rio, we were unable to show any final figures for them. 


\subsection{Non-OCOG Cost Corridors at Olympic Winter Games}

Table 70 Olympic Winter Games estimated and final non-OCOG costs Olympic stadium

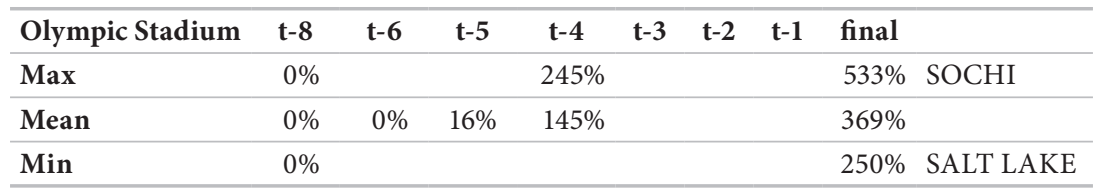

Sources: Anti-Corruption Foundation (n. d.); Aumüller (2014); British Columbia Olympic and Paralympic Winter Games Secretariat (2004); IOC Data; Partnerships British Columbia (2007); Salt Lake City Bid Committee (1994); SLOC (2001); Sochi 2014 Bid Committee (2006); SOOC (2010); VANOC (2010a, b)

The Olympic stadiums for the Olympic Winter Games became on average 369\% more expensive. Turin 2006 used an existing stadium for its Games, for which no investment was needed. PyeongChang 2018 did not plan to build a new stadium when setting the budget. Sochi 2014 had the highest cost overruns for the Olympic Stadium (533\%) and the lowest was in Salt Lake (250\%). These results show that the Olympic stadium became significantly more expensive at the Olympic Winter Games.

Table 71 Olympic Winter Games estimated and final non-OCOG costs ski jumping hill

\begin{tabular}{|c|c|c|c|c|c|c|c|c|c|}
\hline Ski Jumping Hill & $t-8$ & $t-6$ & $t-5$ & $t-4$ & $t-3$ & $t-2$ & $t-1$ & final & \\
\hline $\operatorname{Max}$ & $0 \%$ & & & $37 \%$ & & & & $286 \%$ & SOCHI \\
\hline Mean & $0 \%$ & $-7 \%$ & $-1 \%$ & $19 \%$ & $0 \%$ & & & $94 \%$ & \\
\hline Min & $0 \%$ & & & & & & & $-3 \%$ & TURIN \\
\hline
\end{tabular}

Sources: Anti-Corruption Foundation (n. d.); Aumüller (2014); Bottero et al. (2012); British Columbia Olympic and Paralympic Winter Games Secretariat (2004); Partnerships British Columbia (2007); Sochi 2014 Bid Committee (2006); SOOC (2010); Torino Bid Committee (1998); Vancouver 2010 Candidate City (2002); VANOC (2007, 2010a, b)

The construction of a ski jumping hill seems to be easier to plan and calculate. Only for Sochi 2014 did the originally planned costs have overruns (268\%). As with the Olympic Stadium, PyeongChang 2018 did not plan to build a ski jumping hill, and therefore no figures from the planning stage were available. The five-Games average for the construction of a ski jumping hill was a $94 \%$ cost overruns. 
Table 72 Olympic Winter Games estimated and final non-OCOG costs - sliding centre

\begin{tabular}{llllllllll}
\hline Sliding Centre & $\mathbf{t}-\mathbf{8}$ & $\mathbf{t}-\mathbf{6}$ & $\mathbf{t}-\mathbf{5}$ & $\mathbf{t}-\mathbf{4}$ & $\mathbf{t}-\mathbf{3}$ & $\mathbf{t}-\mathbf{2}$ & $\mathbf{t}-\mathbf{1}$ & $\mathbf{f i n a l}$ & \\
\hline Max & $0 \%$ & $-7 \%$ & $31 \%$ & $59 \%$ & $62 \%$ & & $55 \%$ & VANCOUVER \\
\hline Mean & $0 \%$ & $-7 \%$ & $31 \%$ & $16 \%$ & $62 \%$ & $26 \%$ & $20 \%$ & \\
\hline Min & $0 \%$ & & & $-27 \%$ & & & $-20 \%$ & SALT LAKE \\
\hline
\end{tabular}

Sources: Anti-Corruption Foundation (n. d.); Aumüller (2014); Bottero et al. (2012); British Columbia Olympic and Paralympic Winter Games Secretariat (2004); Partnerships British Columbia (2007); PyeongChang 2018 Olympic \& Paralympic Winter Games Bid Committee (2010); Roche (1994), Sochi 2014 Bid Committee (2006); SOOC (2010); Torino Bid Committee (1998); Vancouver 2010 Candidate City (2002); VANOC (2007, 2010a, b)

The construction of the Salt Lake City 2002 sliding centre showed cost underruns (20\%), while the five-Games average is a cost overrun of $20 \%$. Sochi 2014 was also cheaper than planned. Vancouver 2010 had the highest cost overrun at 55\%.

Table 73 Olympic Winter Games estimated and final non-OCOG costs - ice stadium

\begin{tabular}{llllllllll}
\hline Ice Stadium & $\mathbf{t}-\mathbf{8}$ & $\mathbf{t}-\mathbf{6}$ & $\mathbf{t}-\mathbf{5}$ & $\mathbf{t}-\mathbf{4}$ & $\mathbf{t}-\mathbf{3}$ & $\mathbf{t}-\mathbf{2}$ & $\mathbf{t}-\mathbf{1}$ & $\mathbf{f i n a l}$ & \\
Max & $0 \%$ & & & & & & & $53 \%$ & SALT LAKE \\
\hline Mean & $0 \%$ & $-19 \%$ & $-17 \%$ & $2 \%$ & $-20 \%$ & & $-3 \%$ & $-4 \%$ & \\
\hline Min & $0 \%$ & & & & & & & $-26 \%$ & TURIN \\
\hline
\end{tabular}

Sources: Anti-Corruption Foundation (n. d.); Aumüller (2014); Bottero et al. (2012); British Columbia Olympic and Paralympic Winter Games Secretariat (2004); Partnerships British Columbia (2007); PyeongChang 2018 Olympic \& Paralympic Winter Games Bid Committee (2010); Salt Lake City Bid Committee (1994); SLOC (2001); Sochi 2014 Bid Committee (2006); SOOC (2010); Torino Bid Committee (1998); Vancouver 2010 Candidate City (2002); VANOC $(2007,2010 a, b)$

The ice stadiums have mainly shown cost underruns over the eight years (- the five-Games average is minus 4\%). The only overrun was 53\% for Salt Lake, while Turin 2006 was able to reduce costs by $26 \%$. 
Table 74 Olympic Winter Games estimated and final non-OCOG costs Olympic Village

\begin{tabular}{|c|c|c|c|c|c|c|c|}
\hline Olympic Village & $t-8 \quad t-6$ & $t-5$ & $\mathrm{t}-4$ & $t-3$ & $t-2$ & $t-1$ & final \\
\hline $\operatorname{Max}$ & $0 \%$ & & $625 \%$ & & & & $471 \%$ SOCHI \\
\hline Mean & $0 \%$ & $14 \%$ & $319 \%$ & $12 \%$ & & $-57 \%$ & $179 \%$ \\
\hline Min & $0 \%$ & $14 \%$ & $13 \%$ & $12 \%$ & & & $12 \%$ VANCOUVER \\
\hline
\end{tabular}

Sources: Bottero et al. (2012); British Columbia Olympic and Paralympic Winter Games Secretariat (2004); Hong (2017); Müller (2014); Partnerships British Columbia (2007), PyeongChang 2018 Olympic \& Paralympic Winter Games Bid Committee (2010); Salt Lake City Bid Committee (1994); SLOC (2001); Sochi 2014 Bid Committee (2006); SOOC (2010); Torino Bid Committee (1998); Vancouver 2010 Candidate City (2002); VANOC (2007, 2010a, b)

Due to master plan changes for Sochi 2014, the costs for the Olympic Village changed dramatically and ended up being five times more expensive than planned. Vancouver managed the construction of the Olympic Village well and ended with a 12\% cost overrun. Due to Sochi 2014, the average of cost overruns for the Villages was 179\%.

Table 75 Olympic Winter Games estimated and final non-OCOG costs - IBC/MPC

\begin{tabular}{lccccccccc}
\hline IBC \& MPC & $\mathbf{t}-\mathbf{8}$ & $\mathbf{t}-\mathbf{6}$ & $\mathbf{t}-\mathbf{5}$ & $\mathbf{t}-\mathbf{4}$ & $\mathbf{t}-\mathbf{3}$ & $\mathbf{t}-\mathbf{2}$ & $\mathbf{t}-\mathbf{1}$ & $\mathbf{f i n a l}$ & \\
\hline Max & $0 \%$ & & & & & & & $-11 \%$ & SALT LAKE \\
\hline Mean & $0 \%$ & & & & & & $71 \%$ & $-18 \%$ & \\
\hline Min & $0 \%$ & & & & & & & $-25 \%$ & TURIN \\
\hline
\end{tabular}

Sources: Bottero et al. (2012); British Columbia Olympic and Paralympic Winter Games Secretariat (2004); Fay (2018); IOC Data; PyeongChang 2018 Olympic \& Paralympic Winter Games Bid Committee (2010); Salt Lake City Bid Committee (1994); Torino Bid Committee (1998)

Salt Lake City 2002 had a decrease of $11 \%$ for its IBC/MPC. Turin was also able to save some money from the projected costs (25\%). On average, the IBC/MPC was cheaper than planned in the candidature files (18\%). 
Table 76 Olympic Winter Games estimated and final non-OCOG costs - total

\begin{tabular}{|c|c|c|c|c|c|c|c|c|c|}
\hline Total & $t-8$ & $t-6$ & $t-5$ & $t-4$ & $t-3$ & $t-2$ & $t-1$ & final & \\
\hline $\operatorname{Max}$ & $0 \%$ & & & $175 \%$ & & & & $178 \%$ & SOCHI \\
\hline Mean & $0 \%$ & $-8 \%$ & $11 \%$ & $95 \%$ & $12 \%$ & & $-26 \%$ & $60 \%$ & \\
\hline Min & $0 \%$ & $-8 \%$ & $11 \%$ & $14 \%$ & $12 \%$ & & & $13 \%$ & VANCOUVER \\
\hline
\end{tabular}

Sources: Anti-Corruption Foundation (n. d.); Aumüller (2014); Bottero et al. (2012); British Columbia Olympic and Paralympic Winter Games Secretariat (2004); Fay (2018); Hong (2017); IOC Data; Müller (2014); Partnerships British Columbia (2007); PyeongChang 2018 Olympic \& Paralympic Winter Games Bid Committee (2010); Roche (1994); Salt Lake City Bid Committee (1994); SLOC (2001); Sochi 2014 Bid Committee (2006); SOOC (2010); Torino Bid Committee (1998); Vancouver 2010 Candidate City (2002); VANOC (2007, 2010a, b)

For the Olympic Winter Games, the average cost overrun of venues in our basket was around $60 \%$. All host cities ${ }^{25}$ had cost overruns. The cost overruns of Salt Lake City 2002, Turin 2006 and Vancouver 2010 were at a moderate 13-28\% though. The highest cost overrun was for Sochi 2014, with 178\%.

\subsection{Summary of Costs and Revenues of Olympic Games Seperated by Categories}

In considering the various categories, as well as their most positive and negative manifestations, certain differences arise.

In terms of revenue, the IOC contribution is relatively stable. Since Vancouver 2010, this has been a fixed amount that will be paid out in instalments from four years before the Games onwards. Sources of error are therefore to be looked for in the candidature file, as there was possibly a wrong estimated exchange rate and/or level of inflation used. In the earlier years, from Sydney 2000 to Beijing 2008, the amount was a percentage of the sale of TV rights and could change over time due to the late sale of contracts. The revenue from the TOP sponsorship can be significantly higher (Salt Lake City 2002, Athens 2004) and always - with the exception of Sochi 2014 - led to a revenue overrun. Even higher revenues could be achieved in all cases by national sponsors - Beijing 2008 even received almost five times its expected

25 PyeongChang 2018 was just running during our data collection, so there are no final figures for PyeongChang, but the collected data influenced the mean during the preparation phase. 
revenues. However, a closer look has to be taken on whether the sponsors are state owned, and therefore the sponsorships are indirect subventions. In contrast, revenue from ticket sales is very difficult to predict. Nevertheless, the Games usually create a revenue overrun. In comparing Olympic Games and Olympic Winter Games, the overrun is lower for winter. The revenues of the licensing category are not very predictable, but lead on average to additional revenue. A barely used and seemingly outdated category is the lottery. Looking at the 10 Games, not a single host city actually generated revenues through a lottery. Subsidies are not used everywhere, but we also found large changes here and almost always came to a revenue overrun. A big difference between the Olympic Games and the Olympic Winter Games can be seen in donations. While donations for the Olympic Games are overestimated, they are underestimated for the Olympic Winter Games. The revenue from the disposal of assets can certainly increase, but Winter Games also seem to be more effective than Summer. As previously written, all Games - except Sochi 2014 - had a revenue overrun. Salt Lake City 2002 had the highest revenue overrun of 119\%.

Looking at the expenditures, many categories show differences between the Olympic Winter Games and the Olympic Games. In the venues, and administration and coordination categories, spending at the Olympic Games is changing, whereas for technology and services the fluctuations for the Olympic Winter Games are larger. The categories in which the Olympic Winter Games had cost underruns were venues and administration and coordination. Higher spending is often recorded in the workforce and service categories. The workforce and administration categories are most often estimated with too low costs because the organisation and rapid growth of the OCOG is often underestimated. In contrast, marketing and events is a category in which savings occur, but also cost overruns. Considering all expenditures, the corridor is smaller for the Summer Games than for the Winter Games. This suggests that the costs are more predictable for the Olympic Games.

Regarding the non-OCOG budgets, many Olympic Games venues show severe cost overruns. The swimming pool is on average $105 \%$ more costly, the multipurpose hall $61 \%$ and the velodrome $359 \%$. Among these venues only the swimming pool for Sydney 2000 was cheaper than planned. The cost of the Olympic stadium is very much dependent on whether an existing stadium can be used after modernisation or if a new construction is needed. A new construction often ends with a cost overrun. The Olympic Village can have cost underruns, such as for Athens 2004, but in general cost overruns have to be expected for this mega venue as well. In general, the estimate of the Olympic Village and the IBC/MPC is very important, because they make up the largest part of the overall costs. Thus they highly influence the total percentage of our basket. On average, summer venues are 50\% more expensive than planned. 
The Olympic Winter Games also have great cost overruns. The Olympic stadiums were on average $369 \%$ more expensive, the ski jumping hills $94 \%$, the sliding centres $20 \%$ and the Olympic Villages $179 \%$. The sliding centre's corridor is very small, and the ski jumping hill and Olympic Village are much larger. It is interesting that two venues had cost underruns. The ice stadiums (-4\%) and IBC/MPC (-18\%) were both on average cheaper than planned. Despite this, the construction of venues had an overall average of a $60 \%$ cost overrun.

Open Access This chapter is licensed under the terms of the Creative Commons Attribution 4.0 International License (http://creativecommons.org/licenses/by/4.0/), which permits use, sharing, adaptation, distribution and reproduction in any medium or format, as long as you give appropriate credit to the original author(s) and the source, provide a link to the Creative Commons licence and indicate if changes were made.

The images or other third party material in this chapter are included in the chapter's Creative Commons licence, unless indicated otherwise in a credit line to the material. If material is not included in the chapter's Creative Commons licence and your intended use is not permitted by statutory regulation or exceeds the permitted use, you will need to obtain permission directly from the copyright holder. 


\section{Reflections}

\subsection{Theoretical Explanations for Olympic Cost Overruns}

In this reflection we offer explanations about the different drivers that initiate cost and revenue overruns. Before we issue our 17 recommendations, we will use several theories that help us to understand why cost and revenue overruns occur. The theory is important to consider because it will emphasise our recommendations.

The reasons for Olympic Games cost overruns are many, and these can be explained by several phenomena. Reasons that trigger cost overruns may be casual, happening just by chance (at random) or more basic and systematic, i.e. structural.

Casual causes are:

1. Unpredictable and uncertain factors generate delays in the project achievement - which is often the case in the construction industry. Then the project that is lagging behind schedule must be finished in a rush, which always causes extra costs; therefore $C_{t}>C_{t-n}$.

2. Mismanagement of the project. This might have happened in some cities that hosted the Olympic Games, although this must be the exception rather than the rule.

3. The project has been conceived and designed with too high expectations in terms of short duration and low (or not too high) cost which is usually due to decision-makers' excessive optimism and/or ambition. Although such a mood

(C) The Author(s) 2019

$\mathrm{H}$. Preuß et al., Cost and Revenue Overruns of the Olympic

Games 2000-2018, Event- und Impaktforschung, 
may have surrounded the preparation of some Olympic Games, it cannot be considered as a recurrent source of cost overruns even though excess optimism may lead to one of the two structural causes below.

Consequently, such causes of cost overruns that emerge haphazardly, at random, cannot be generalised in terms of an economic analysis of the Olympic Games, even less could they be incorporated into a theoretical approach of the Olympic Games cost overruns.

From an economic standpoint, structural causes of cost overruns in long duration Olympic projects can be theorised once they are identified as:

1. The local Olympic project governance is weak or bad, which means that (some) local decision-makers who host the Games do consider their budget as rather lax and are ready to envisage that expenditures (costs) could run over budget; and the project is run under a so-called soft budget constraint (Kornaï, Maskin \& Roland 2003). Usually economists consider that this managerial misbehaviour has its roots in some inappropriate set of institutions and hence resort to institutional economics. The soft budget constraint is a concept that has already been called into sports economics analysis (Andreff 2007; Storm \& Nielsen 2012), though not in the case of mega-sporting events, namely for explaining cost overruns. An alternative attempt at analysing weak governance, i.e. resulting from inappropriate institutions, and the subsequent "structural" managerial misbehaviour, is the PRINCIPAL-AGENT model (Jensen \& Meckling 1976; Fama \& Jensen 1983; Laffont \& Martimort 2003), which has also been applied in sports economics though not for studying the Olympic Games (Miceli 2004; Andreff 2015) either, despite the fact that it seems to be a theoretical framework that helps explain cost overruns. It is therefore adopted below in this study.

2. The use of public funding and public goods: The occurrence of soft budget constraints and cost overruns is more probable when public funding is involved in the host city's financing of the Olympic Games. When a non-negligible share of an Olympic project is financed on public funds, then an opportunity emerges for local decision-makers (primarily politicians) to overload the project with expenditures (costs) that would not have been planned otherwise (the famous watchword that "hosting the Games will facilitate and accelerate the building of new non-sporting infrastructures"). With public finance, there is always an incentive to spend without counting (since it is not your own but public money), to bargain additional subsidies and the like. In the worst case of actually bad governance, corruption may arise. Obviously, analysing this facet of cost overruns calls for some references to the public choice theory, in particular free-riding 
behaviour in the face of the request for financing public goods. It is therefore adopted below in this study.

3. The Olympic project is allocated to host cities through an auction or an auction-like process. This is the winner's curse theory of Olympic cost overruns (Andreff 2012 , 2014), which is briefly recalled below and used as a third theoretical interpretation of the emergence of lasting cost overruns linked to the allocation mode - through an auction-like process - of the Olympic Games. It is therefore adopted below in this study.

In short, we will offer theoretical reflection by using the following theories:

- Neo-institutionalism theory. In this theoretical framework, we will address in particular:

a. The Principal-Agent Theory and its adverse selection problem

b. The Principal-Agent Theory and its moral hazard problem

c. The Public Choice Theory

- The Theory of public goods and its inherent free riding problem

- The Auction theory and in particular the "Winner's Curse"

- Evolution theory, public interest theory and planning fallacy theory

\subsubsection{The Neo-Institutionalism Theory and Cost/Revenue Overruns}

\section{Adverse selection problems}

The following explanation is related to the often strategically desired underestimation of costs during the bidding stage. This section explains why we strongly suggest to any reader to interpret cost overruns only after the Games were awarded to a city and the first serious cost estimate was made. This study has clearly shown that a realistic cost estimate can usually be done three to four years before the Games.

Due to the competitive bidding and the Olympic auctioning process, cost estimates requested by the sports governing body is different for each mega project (e.g. Preuss \& Schnitzer 2015). Non-sport mega projects tend to have much more controlled and expected cost estimates because they are from one industry. Therefore, it is debatable whether an interpretation of cost and revenue overruns should be taken from the time span of a first (very early) cost estimate or a little later from the official bidding documents or even later from the first cost estimate based on the true knowledge of the project. Reflecting this, we wonder, why does the IOC continue 
to demand cost/revenue estimates in the candidature file? If the above reasoning is right, everyone is supposed to know that this first cost and revenue estimate must necessarily be wrong and only four years before the Olympic Games the organisers have a full picture and valid overview. Thus, taking the cost and revenue estimate from the official candidature files means taking a politically influenced cost/revenue estimate that is presented to the population, and therefore we can already explain two factors for cost overruns. One is the political setting of the budget, and the other is a strong uncertainty about the number and size of projects that are really needed for the Olympic Games. The overall question here is, whether the cost and revenue estimate presented to the IOC members (before voting) has an impact on their decision. If so, the IOC may take this information out.

Based on the information that the local residents/population have about a potential Olympic Games, they want the Games or they reject them (in recent years many referendums were lost thus indicating that those that are voting do not want the Games). If the Games seem to be attractive, the population wants to bid for the Olympic Games and directs their desire towards the "political system" of the city/NOC. This is a classical PRINCIPAL-AGENT situation, which is a "pervasive fact in economic life" (Arrow 1985a, 37). Constitutional for a PRINCIPAL-AGENT relation is that the utility level of the principal is influenced by the agent's auction (Picot, Dietl \& Franck 2005, 72). The AGENT, here the political system, has better information about the costs and revenues of the Olympic Games than local residents/population (PRINCIPAL). The so-called information asymmetry gives an advantage to the AGENT. The AGENT (political system) can take opportunistic advantage by exaggerating the (own) positive event effects and/or just undermining costs and other negative effects when reporting to the PRINCIPAL (local residents/ population). This is an important observation because the information politics (which can be pro Olympic opposition or Olympic supporters) influence the outcome of a public referendum.

Local residents/population acquire their information about the potential benefits of the Olympic Games through various channels (Preuss 2004, 49). These are:

a. Information and advertisements, which are often spread by the AGENT (the bid committee or local politicians), but also

b. Information published by the media, and opposing and lobby groups. Due to the complexity of Olympic-related projects, which can easily be more than 200 , the cost estimates, including non-Olympic costs, sometimes tend to be extremely high.

c. Information about the event, which was staged in another city. Information is passed on through TV reports, live coverage or print media articles. 
d. Personal experiences with other (mega) sporting events at home or abroad in the past.

The information provided to the local residents/population is usually not comprehensive enough for them to reliably assess the potential benefits of the Olympic Games for themselves. Therefore, the local residents/population do not know the real cost-benefit balance of a future mega sport event in their city.

Looking at the interaction between those involved in a bidding process, we can observe a cascade of PRINCIPAL-AGENT relations where the AGENT becomes PRINCIPAL in another relation (see also Picot, Dietl \& Franck 2005, 2). In each cascade, the interest in showing the true costs of Olympic Games is not fully explained.

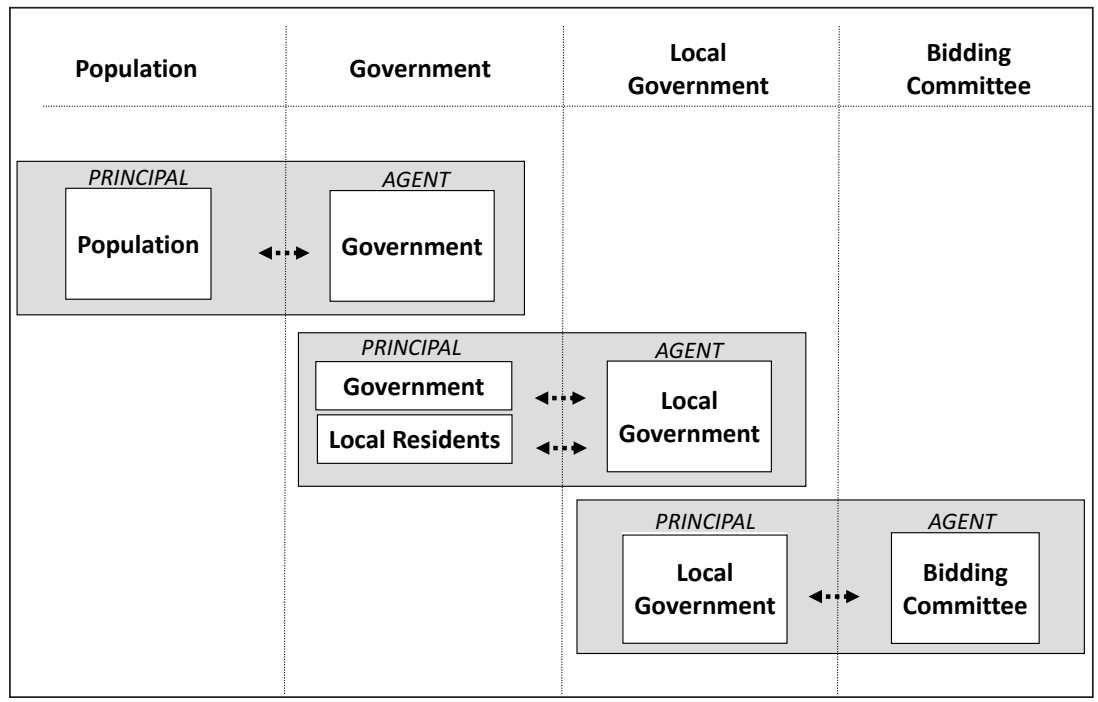

Fig. 44 Cascade of PRINCIPAL-AGENT relations

Opportunistic behaviour of the AGENT is most likely. The PRINCIPALS and AGENTS follow different aims, but the information asymmetry avoids transparency. Even though both want to have successful Olympic Games staged, the benefits and opportunity costs of the Games are different for each group and lead to opportunistic behaviour. The AGENT (in our bidding scenario, the bid committee is better informed) has to follow the objectives of the PRINCIPAL, but will adopt opportu- 
nistic behaviour geared towards its objectives. Despite the opportunistic behaviour of the AGENT, the PRINCIPAL usually obtains a benefit from the relation. Both follow a win-win situation, also called non-zero-sum situation, because the main objective (successful Games) is the same without a conflict in this interest. Due to the complexity of Olympic Games projects (investments) and the large number of cost areas, the PRINCIPAL is not able to observe and judge all actions of the AGENT. Additionally, other stakeholder have an influence on the activities of the $A G E N T$ (e.g. demand from officials of international federations, mayors of suburbs or related communities, federal politicians/senators) and make the action of the AGENT opaque. Finally, the performance of the AGENT towards a successful bid is insecure, because only one bidding city can win the right to host the Olympic Games. All these factors complicate the PRINCIPAL'S possibility of controlling and judging the importance of the AGENT'S activities. In other words the AGENT can act opportunistically (which means using the Olympic bid) to maximise its own benefits. This can be an additional infrastructure project, higher construction costs (if he participates by a certain percentage based on the overall costs of the construction), the choice of other locations than those being cheaper, etc. All this leads to an increase in the budgets and later to cost overruns.

When bidding for the Olympic Games, the bid committee has the best information. Local politicians have the second best information, followed by the governmental politicians. The local residents/population, finally, have little information. This means that there is great information asymmetry between the PRINCIPALS and AGENTS. The next table displays the different roles and objectives of the PRINCIPALS and AGENTS.

Table 77 Principal-agent relations in the bidding process for a mega sports event

\begin{tabular}{|c|c|c|}
\hline Cascade level & Principal & Agent \\
\hline 1 & $\begin{array}{l}\text { Population (nation) } \\
\text { demands the Olympic Games }\end{array}$ & $\begin{array}{l}\text { Government } \\
\text { subsidises the Games (infrastructure } \\
\text { of city) and supports the bid, provides } \\
\text { financial guarantees }\end{array}$ \\
\hline \multirow[t]{2}{*}{2} & $\begin{array}{l}\text { Government } \\
\text { demands the Games, which pro- } \\
\text { mote economic growths, interna- } \\
\text { tional prestige, national presen- } \\
\text { tation, etc. }\end{array}$ & \multirow[t]{2}{*}{$\begin{array}{l}\text { Local Government } \\
\text { subsidises the Olympic Games and ex- } \\
\text { pedites city development, local repre- } \\
\text { sentation, provides political support and } \\
\text { backs the bid }\end{array}$} \\
\hline & $\begin{array}{l}\text { Local residents (city) } \\
\text { demand the event }\end{array}$ & \\
\hline
\end{tabular}




\begin{tabular}{lll}
\hline Cascade level & Principal & Agent \\
\hline & $\begin{array}{l}\text { Local Government } \\
\text { demands profitable organisation } \\
\text { of the Games and long-term ben- }\end{array}$ & Bid Committee \\
efits from the event in regard to the & because success is visible and the PRIN- \\
long-term city development, local & CIPAL will rate that \\
representation & \\
\hline
\end{tabular}

The initial initiative to bid for the Olympic Games often comes from private groups or local politicians. Their intention is often different from that of the local residents/ population. For example, the initiative to bid for the Olympic Games in Atlanta for 1996 came from the construction industry seeking new business. The Barcelona politicians wanted the Games to be one (out of many) driver for redeveloping the city, the Catalan government wanted to promote Catalonia as a rival to Madrid, and the central government wanted to control the Olympic Games as Spanish Games (Botella 1995, 143). These objectives were used to justify substantial public investment during the Olympiad and to create within the city and the province of Catalonia the desired impetus to take stock of the long-term under-investment in leisure, culture, sport and transportation during previous decades (Millet 1995, 191).

\section{Moral hazard problems}

Each AGENT - being in another relation PRINCIPAL - will use scarce public resources to promote the Olympic Games and take opportunities to reach its individual targets. In such situation, the AGENT cannot be observed (lack of transparency), which leads to the opportunity for the AGENT to make decisions for its own benefit (moral hazard). These can be, for example, to re-plan parts of the city that are not necessarily needed for the Olympic Games, but the city may manage to get the national taxpayers to pay the bill. The information asymmetry enables the AGENT claiming that this re-planning was necessary for the Games. This happened for example in Athens, when, only three years before the Games, the Olympic Stadium surroundings were nicely upgraded by star architect Calatrava which cost more than EUR 200m covered by the Greek state to incorporate design excellence (Pollalis 2006, 4).

This PRINCIPAL-AGENT theory helps to explain a certain ineffectiveness in investing public resources (national taxpayer perspective) for the Olympic Games. However, for a local taxpayer, this investment paid by national taxpayers is very effective. In contrast for the national taxpayers it tends to be less effective because they do not benefit from local city development since they do not live in the host city. 
The problem addressed here is that too many AGENTS are involved in the bidding for and preparation of the Olympic Games and all want to benefit from the project, but those who have to pay the bill (taxpayers) do not have enough transparency (a typical moral hazard problem). Thus the opportunistic behaviour of AGENTS makes the Olympic Games a mega project that contains hundreds of smaller investment projects to make them benefiting and this finally increases the overall costs.

The many public referendums (see introduction) have shown that taxpayers are concerned about the financial control of such a project. The negative referendums and thus the decrease in the number of bid cities have shown that the PRINCIPAL is still very important and the support of local residents and national population is important to win an Olympic bid.

\section{Public choice theory}

Public choice theory can help explain cost and revenue overruns based on political behaviour. In particular we want to refer to conflict of interests. In regard to cost overruns, we need to study self-interested AGENTS (politicians, officials from International Sport Federations or city developers) and their interactions. Their position during the bidding stage for the Olympic Games or later on during the construction phases helps explain lower cost expectations by looking at their utility maximisation or the way of decision taking.

The theory on conflicts of interests is also based on the PRINCIPAL-AGENT setting. The AGENT has to fulfil the job given by the PRINCIPAL, but will use information asymmetry to maximise his/her benefits following his/her own agenda.

Politicians or sport officials often have a conflict of interests by having multiple positions/functions or when they have to trade-off between several projects. Rational choice theory teaches us that people consider their preferences, opportunity costs and institutional/cultural/organisational constraints whenever they have to decide between different projects. It is normal for many projects to have conflicting aims. Regarding the construction of sports venues the decision taken may often be in conflict with the best practice for taxpayers. Information asymmetry helps to make a decision against the interest of the taxpayer (PRINCIPAL), and often this asymmetry is an incentive to follow a selfish interest. Examples of this are when a local politician gets governmental money for local infrastructure, an architect increases the costs of a project as he/she gets a percentage of the project as his/her salary or someone owns an area and wants an upgrade of the surroundings. For the Olympic Winter Games, people who own ski resorts want better traffic connections or someone who owns construction companies wants contracts.

What the IOC can do is to reduce this information asymmetry by, for example, better informing about the infrastructure required for the Olympic Games. In other 
words, if the IOC openly tells the population what is needed or which sports facility is sufficient to stage Olympic Games, this will lower the information asymmetry and diminish the opportunistic behaviour of the agent.

\section{Public goods and free riding}

Most of the capital investments for the Olympic Games are financed from public resources. The reasoning for this is that the infrastructure built and the Olympic Games in general are of national interest. Therefore, public subsidies are justified. However, many stakeholders benefit from the projects but do not have to pay for them. For them, utility maximising means using public resources for their own benefit. This can be:

a. an official of an International Sports Federation who wants to have a new sports venue for his/her sport for training or competition;

b. an architect who earns his/her salary based on a share of the overall contract;

c. a construction company that earns money by adding extras as much as a contract allows it to do so;

d. the hotel and tourism industry that wants more attractions and better infrastructure.

In contrast to the above-mentioned conflicts of interests, here we face the problem that those deciding do not have to pay, but benefit from the decision taken. This leads to an overspend of public money and to cost overruns.

In other words, when a share of an Olympics' project is financed from public funds then an opportunity emerges for local decision makers (primarily politicians) to overload the project with expenditures that would not have been planned otherwise and are not needed for the hosting of the Games. The famous watchword that "hosting the Games will facilitate and accelerate the building of new non-sporting infrastructures". With public finance there is always an incentive to spend without counting (since it is not your own, but public money), to bargain additional subsidies and the like. In the worst case of actually bad governance, corruption appears.

Most revenue overruns - in particular when they take the form of extra-profit or rent - usually accrue to private owners, enterprises, local decision-makers, etc., who are not compelled to invest or consume in the local economy. While cost overruns are often (at least partly) covered by public funds, which means, at the end of the day, by some (local and/or nationwide) taxpayers. When it is so, a well-known outcome in economics emerges: indirectly or directly public funds (then taxpayers) are paying for privately appropriated extra-profit or rent - in other words: "social deficits fuel private profits". If one wants to enhance the acceptability of hosting 
the Olympic Games by potential host city populations, this is the kind of situation that must be drastically combatted and cured. That is why, beyond the issue of cost overruns, the appearance of a deficit is even more crucial and, consequently, the emergence of revenue overruns that may or may not cover cost overruns.

\subsubsection{Auction Theory: The Winner's Curse}

Above we have mentioned many causes for cost overruns. However, one more interesting cause can be derived from the auction theory - as long as the Olympic Games are awarded through an auction-like process that can fuel a so-called winner's curse. The latter occurs when the project has been conceived and designed with too high expectations (overestimation), for instance in terms of short duration or significant economic impact and with too low or not high enough costs (underestimation), which is usually due to decision-makers' excessive optimism and/or ambition.

The winner's curse phenomenon was discovered when explaining the unexpected low returns to companies engaged in competitive bidding for oil and gas leases in the Middle East (Capen, Clapp \& Campbell 1971). Further on, the winner's curse theorem was demonstrated namely by Richard Thaler, the 2017 Nobel Prize winner in Economics. Thaler (1994) wrote: "In any auction-type setting where the value of the auctioned object is uncertain but will turn out to be the same for all bidders, the party who overestimates the value is likely to outbid the competitors and win the contest".

This theory was applied to explain cost overruns when hosting the Olympic Games (Andreff 2012, 2013, 2014, 2016), now summarised here:

1. Ex-ante (before awarding the Olympic Games), nobody knows the value of hosting the Games.

2. Through the bidding process, the IOC expects to obtain the best possible Olympic Games in terms of quality and is looking through an auction-like award process for a guarantee of well-functioning and secure sports contests, excellent quality Olympic venues and hosting accommodation, impressive opening and closing ceremonies, high-quality media and telecommunications and, increasingly, environmental quality. The problem is that the IOC also (just like the taxpayers above) operates under an information asymmetry about the details of each candidature file.

3. The objective function of bidding cities consists in obtaining the right to host the Games and, for this purpose, in overbidding each other, and eventually outbidding all competing cities. Each bidding city must promise fixed quantities of sporting facilities requested by the IOC. Usually the city also fills its candidature file with a lot of promising general non-sporting infrastructures, which is the 
most important trigger of the winner's curse and cost overruns - even though this kind of costs are not taken on board in the present study.

4. As in all auctions or auction-like allocations of this kind, the winner is the most optimistic bidder, i.e. the one who underestimates the cost (and/or overestimates the benefit, for instance the impact and legacy). Usually an overoptimistic economic impact study, produced by a well-known commercial or marketing agency, is instrumental in highlighting the best features of the bidders' projects and shadowing or blurring the lesser ones. Then the most optimistic bidder wins the bid but will be cursed because it will have to pay for the actual ex-post cost and not for the ex-ante underestimated cost.

5. The bidding process is an auction-like awarding. If there is just one candidate to host the Games, then there is no winner's curse and no (structural) cost overruns.

This theory has been successfully tested in Andreff (2012, see Tables for all Olympic Games from Munich 1972 on and Winter Games since Lake Placid 1980), including the exception that confirms the rule: Los Angeles, the only candidate for hosting the 1984 Olympic Games, did not have any cost overruns. Other studies have exhibited cost overruns, though not in the context of the winner's curse theory, such as Preuss (2004) and Solberg \& Preuss (2007), who showed an increase in the operational and construction costs between the first and the last estimate for all Olympic Games from 1972 to 2000.

\subsubsection{Public Interest Theory vs Chicago Theory: Market Regulation to Favour Public Interest?}

The Public Interest Theory explains in general terms that regulation seeks the protection and benefit of the public at large. The Chicago Theory (also known as the Economic Theory of Regulation), suggests that regulation does not protect the public at large but only the interests of groups (Hantke-Domas 2003, 165).

Public interest can be further described as the best possible allocation of scarce resources for individual and collective goods. In other words, it questions whether the use of public money for the Olympic Games is the best spending for the population. For each Games the answer is different. The better the legacy and the smaller the public money share, the better the Games serve public interest. However, the negative referendums in the past indicate that the public seem to be against the Olympic Games, or at least the bid committees are not able to sell the benefit to be expected from the Games. 
In these theories, regulation means the employment of legal instruments for the implementation of social-economic policy objectives. For example, the government can establish economic and social regulations in order to realise goals like allocative efficiency, stabilisation or fair and just income distribution. The question is, if the Olympic Games can be such an instrument.

The Public Interest Theory has two acceptable concepts. The first explains that regulation seeks the protection and benefit of the public at large. The second defines it as a system of ideas, which proposes that, when the market fails, economic regulation should be imposed in order to maximise social welfare (Hantke-Domas 2003, 166).

In modern economies, the allocation of scarce resources is mainly coordinated by the market. In theory, this allocation of resources is optimal, but these conditions are frequently not fulfilled in practice. The allocation of resources is not optimal and there is a need for methods to improve the allocation. Therefore, the IOC should not expect that awarding the Olympic Games will finally benefit the population in the way it is expected. There may be a need for regulation based on a contract to better ensure social welfare provided by a mega project such as the Olympic Games.

One of the methods for achieving efficiency in the allocation of resources is government regulation (Arrow, 1985b). However, the question is if the government can control the Olympic project properly. Thus it was good that Sydney 2000 started to have a ministry coordinating the projects and other host nations followed. This will be shown in our recommendation 9 (see below).

\subsubsection{Evolution Theory and Planning Fallacy Theory}

Furthermore, evolution theory can be used to explain cost overruns. Evolution theory describes the formation and change of units that are the result of a development process in a scientific way (Cambridge Dictionary, n. d.). Cost overruns can be explained using the theory of evolution, as there are changes in scope and definition between the initial phase and the completion of the project (e.g. Odeyinka et al. 2012). For the Olympic Games, these may include technical developments like the support of drones during the Opening Ceremony in PyeongChang. In addition, the network coverage of the country can be improved to allow for better TV transmission or result transmission. These technical changes are associated with evolution. Therefore, it is important to know exactly what is needed. This fact is considered in recommendation 1 (see below).

In addition, the psychologically based planning fallacy theory can also help to explore cost overruns. Planning fallacy theory is a phenomenon that deals with optimistic estimates of temporal predictions of future work. The time required 
for tasks to be set up is optimistically underestimated. This theory was first described by Kahnemann \& Tversky (1979). Although the individual may already have experience and knowledge of previous similar tasks that have taken more time than anticipated, this phenomenon occurs in spite of it. Above all, these are predictions of one's own tasks. Outside observers tend to overestimate the time required pessimistically. Lovallo \& Kahneman complemented the existing theory in 2003, adding the components of costs and risks that are underestimated while overestimating the benefits of the action. In summary, the theory describes the time overruns, cost overruns and benefit shortfalls of tasks and projects, which in turn can be combined with the auction theory (see Auction Theory chapter). Recommendation 3 deals with the fact that there should be no strategic cost underestimations to minimise cost overruns.

\subsection{The Evolution of Olympic Budgets and Their Economic Consequences}

\subsubsection{Evolution of Olympic Budgets}

The difficulty in coordinating the organisation of the Olympic Games becomes obvious when looking at the total number of changes, for example at the Salt Lake City 2002 Organising Committee (SLOC). Between July 1999 and March 2002, the SLOC had processed 2,551 change orders ${ }^{26}$ and had to manage 3,780 contracts (without venue construction) (Hopkins 2002, 15).

26 Change orders are the "unilateral written order by a project owner directing the contractor to change contract amount, requirements, or time. Such changes must be within the scope of the contract and in accordance with the contract's changes clause to be legally implemented without the consent of the contractor" (Businessdictionary, n. d. b). 


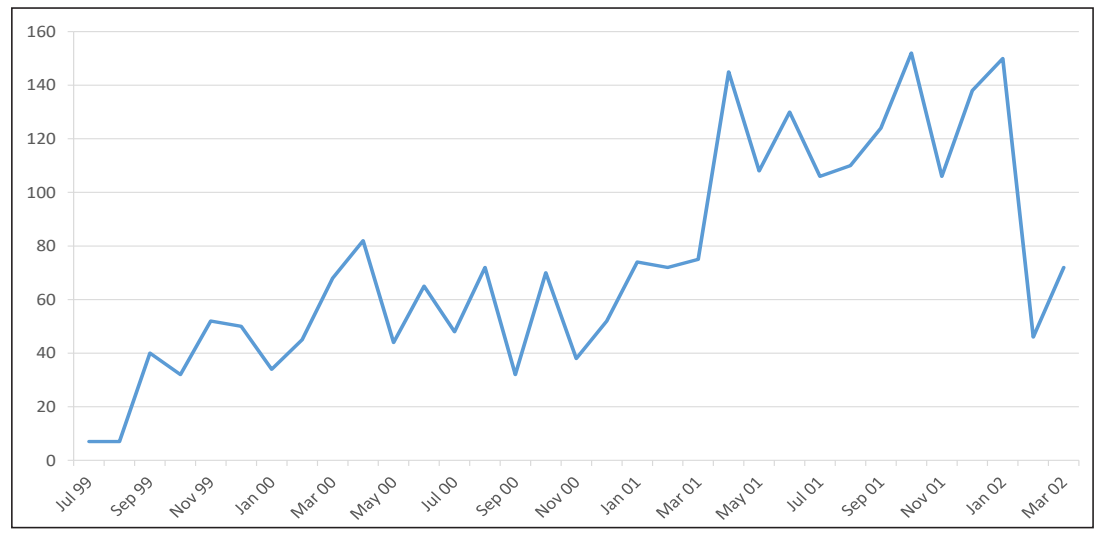

Fig. 45 Number of change orders at SLOC

Source: Hopkins $(2002,15)$

Our study of 10 Olympic Games shows that the typical evolution of an OCOG budget is as follows:

1. The bidding budget his very roughly estimated. We found that many smaller projects were not considered, venues were planned too small or in a location that was not feasible enough to be used. That leads to later changes in the master plan.

2. This bidding budget is only slightly adjusted, even after winning the bid, until approximately four years before the Games. In this phase ( $t-7$ and $t-4)$, we found very little data and this could prove that there are not many efforts taken to keep control of the budgets. It seems that the government authorities change the master plan during this time and also follow stakeholders' and politicians' interests. These changes in the master plan are basically because, after winning the bid, the OCOG needs to re-do the planning until it is staffed, people understand the project, build relationships with stakeholders and understands the needs. Changes happen until the plans become more detailed and budgets more accurate.

3. Approximately four years before the Games, the government authorities and the OCOG have a clear view about what exactly is needed and how to satisfy the various stakeholder interests. At this time, the budget usually has high cost overruns. Pressure from the public and political opposition starts.

4. Then, a year before the Games, great efforts are undertaken to reduce costs and try to increase revenues. Financial changes can be expected that usually end in a balanced OCOG budget (through greatly increased revenues and moderate 
expenditure overruns), and capital investments also end up with a moderate cost overrun. Interestingly, this is quite different from project to project and depends a lot on changes in the master plan.

The measures taken in step 4 have sometimes been significant. The reduction of costs is often possible because free riders and opportunistic behaviour as well as budget cuts can be made without endangering the Olympic project. The next figure illustrates the gap evolution of the SLOC budget for Salt Lake City 2002. Here the revenue overruns helped to balance the budget during Games time, but most important was the cut in expenditure from USD $1.51 \mathrm{~m}$ down to USD $1.27 \mathrm{~m}$.

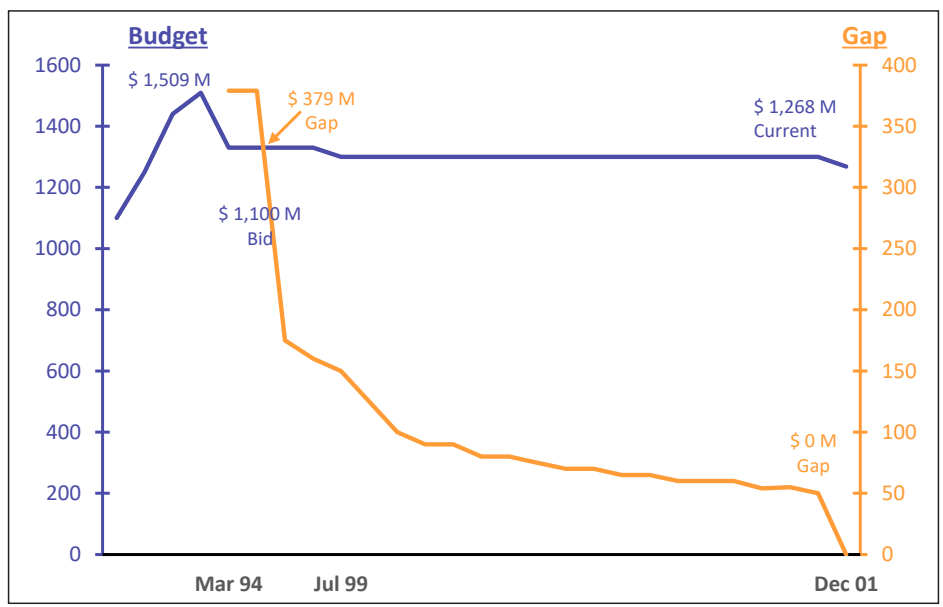

Fig. 46 Budget evolution and financial gap at SLOC (2002)

Source: Hopkins $(2002,36)$

The budget changes were quite extensive as the next figure shows. Here, SLOC managed to cut the budget by almost $32 \%$, although an increase of almost $23 \%$ was later necessary. 


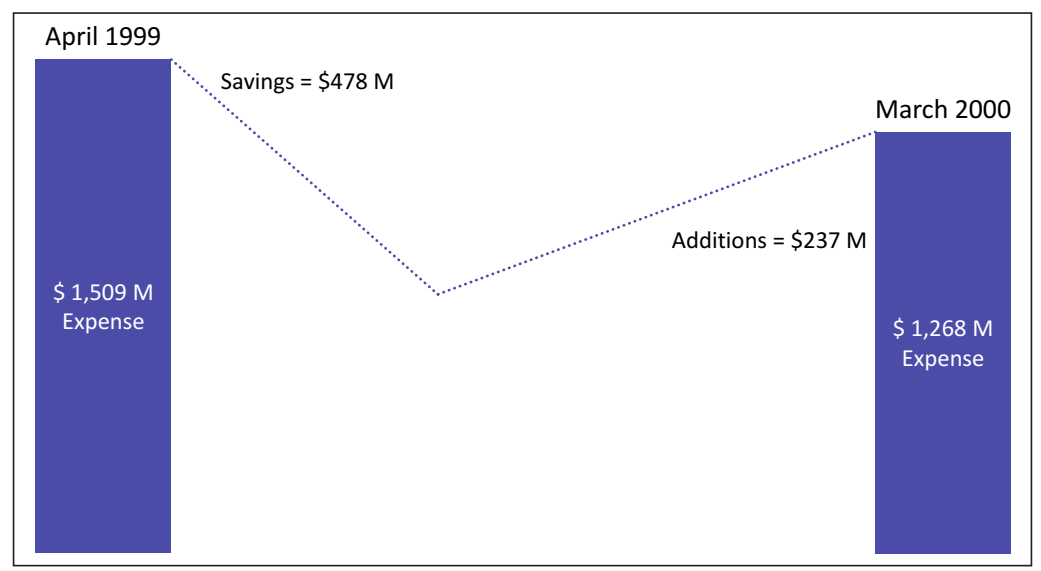

Fig. 47 Volatile budget development at SLOC (2002)

Source: Hopkins $(2002,39)$

\subsubsection{Economic Consequences: Cost Overruns, Revenue Overruns and Deficit}

If cost overruns are obviously caused by the Olympic Games (preparation, staging and legacy), then we should also observe overruns (ROV) of the revenues:

$$
C O V=>k \cdot R O V
$$

An important question is, what does it mean if revenue overruns are equal, higher or lower than cost overruns: $k \geq 1$ or $k<1$; or whether the below inequality (1) or (2) prevails.

The final outcome (deficit or no deficit) depends on the comparative size of cost overruns and revenue overruns:

(1) If $R O V \geq C O V=>$ no deficit

(2) If $R O V<C O V=>$ deficit

The hypothesis that $R O V=C O V$ or $k=1$ may occur only by chance. Otherwise, there is a (multiplier-type) argument in favour of $k>1(R O V>C O V)$ which is: increased revenues (overruns) triggered by cost overruns will not be entirely saved, at least a 
part being consumed, another one purchasing imports; therefore $k>1$ - under the usual assumption that $c>e$, where $c$ stands for the marginal propensity to consume locally and $e$ for the marginal propensity to import locally ${ }^{27}$. Other occurrences can emerge that would trigger $R O V<C O V(k<1)$ :

1. A specific investment within the Olympic Games overall project eventually appears to be more expensive than forecast in the candidature file. Here, cost overruns are simply due to an (unexpected) extra cost without any change in the investment programme. Then unexpected extra revenues usually accrue in the form of profit or extra-profit to some enterprise(s), and this does not necessarily fuel a new other investment (financed on extra profit) in the local economy, and probably never increases local consumption. In such occurrence, probably $k$ is below 1 , possibly $=0$.

2. Delayed completion of an Olympic Games investment is another source of cost overruns. When a project is lagging behind the expected schedule, it must be finished in a rush with higher costs (extra employment, overtime work, etc.). Again, this may increase some enterprises' turnover and profit without any guarantee of a subsequent increase in consumption, and probably with $k<1$.

3. Cost overruns, whatever their cause, may be taken over by public authorities through a subsidy. How this affects the local economy will very much depend on how this extra public expenditure is financed. As, with the Olympic Games, it is sometimes financed through an increase in consumers' and/or investors' taxation, then it is unlikely that $k>1$ and it is extremely probable that, through reduced consumption and investment by overloaded taxpayers, $k$ will be lower than 1 , maybe equal to zero.

4. At the end of the day, cost overruns may lead to local fiscal deficit and/or public debt. Again, the burden usually falls on the shoulders of taxpayers, and this will reduce $k$ below 1 , and sometimes to zero.

5. The worst case (as suspected with the Athens 2004 and Sochi 2014 Games) is when costs run over due to speculation, bribery, black boxes, corruption and the like. Then cost overruns simply fuel extra revenues of a rent-type which, at the end of the day, have no chance of feeding the local economy in any way. For sure, from the standpoint of the local economy $k=0$.

27 In a small economy very much open to trade, it may happen that $c<e$, and thus $\mathrm{k}<1$. We do not discuss this case since none of the editions of the Olympic Games has been hosted in a small open economy since 2000. Even though Athens 2004 is a small economy, it had access to the European market. 
All in all, the risk is higher that finally $k<1$, that is $R O V<C O V$ in most Olympic Games non-OCOG budgets because one or several of the above occurrences 1,2, 3, 4 or 5 is/are at work. One objective and value added of the present study is to check the comparative magnitude of $R O V$ and $C O V$.

\subsection{Practical Recommendations to Reduce Cost Overruns}

This study brought up several key learnings that can be transformed into recommendations to the IOC, OCOGs, host cities and public authorities. Many of them are suggestions for controlling factors that lead to cost overruns. In the following we do not suggest points for controlling revenue overruns, as an underestimation of revenues is conservative; moreover, contrary to cost overruns, revenue overruns are unexpected good news and basically do not require monitoring.

- R1: Cities need to receive earlier guidance about capital investments required for the Games.

One key learning from this study is that the idea of staging the Olympic Games usually comes from the desire for (political) worldwide recognition, sport organisations and from the wish to develop the host city. Financial planning and full awareness of which investments the Olympic Games require are often only formed during the bid. Usually a first feasibility or impact study is undertaken. Then, in a difficult process of coordinating many stakeholders' interests, a first budget is produced right before the candidature file is submitted to the IOC. The stakeholders' interests can be very controversial. Some demand the minimisation of capital investments. Others like to use the opportunity of hosting the Olympic Games to add many additional projects (park lands, airports and suburbs, rail systems etc.) in the hope that most of that will be paid by the government and not the city community.

The Sydney 2000 financial plan from September 1990 shows how different the first sketch of the Games budget was and how much that already changed in comparison to the Candidature File in 1993.

One main reason for wrong cost estimates is often a lack of knowledge about what exactly is required for hosting the Olympic Games. The IOC should better educate the bid cities about the cost structures and cost overruns witnessed in 
previous Olympic cities ${ }^{28}$. It should offer workshops to give better understanding about the needs and complexity of the Games. Furthermore, the IOC could teach (demand) using modern techniques in cost estimates and project planning. Some underestimations of costs can be avoided this way.

- R2: The IOC should alleviate pressure on cities during the bidding stage in order to reduce the risks of a winner's curse.

However, often it also looks like politicians wanted a lack of realism for their initial cost estimates in order not to kill the idea of staging the Games by too high costs. Another reason may be that politicians underestimate the costs of hosting the Olympic Games by overestimating the benefits. This leads to the winner's curse because too many costly promises (e.g. the construction of new sports facilities) are made during the bidding, and later these promises have to be kept.

Therefore, it would be good if the IOC consulted the cities about what infrastructure is really needed for the Olympic Games. The new format of "dialogue" which the IOC has put into place as part of its Olympic Agenda 2020 to ensure the fit of the city to stage the Olympic Games but also more importantly how the Games can fit the city, is a first step. As part of this roadmap, the new approach towards Olympic bidding and hosting, called The New Norm, was launched early 2018 (IOC 2018b). The Olympic candidature and hosting model seems to have evolved with affordability, sustainability, legacy and maximising the use of existing infrastructure being as priorities into the early discussions and requirements of the IOC. The idea is for the process to allow for a continual improvement of each Games project and ensure that the Games best fit a city and region's long-term development plans and ambitions.

If this proves to be put into practice, then the candidate cities will rightly focus on themselves without comparing themselves with the other cities.

- R3: The IOC should work against strategic low-cost estimates to protect the taxpayer and should ensure figures given are as realistic as possible.

This recommendation can avoid two things. The IOC can avoid the strategically set low-cost estimates and thus protect the taxpayer against wrong information;

28 The IOC already holds workshops for the bid cities advising on what areas were underestimated or not fully scoped for past Olympic Games. 
and it can avoid disappointment about budget overruns in the following years. As it is difficult to increase the contingencies (currently they are already around $10 \%$ of the total budget) to counteract possible changes in the master plan, the costs should be estimated realistically. This should also be monitored by the IOC and supported by the transfer of knowledge from previous Games.

If the IOC is participating in budget estimates, local politicians and other stakeholders cannot easily add on non-Olympic projects without justification.

- R4: The host city should start constructing the required infrastructure as soon as the Olympic Games are awarded.

The length of construction for mega projects and cost of delays are often underestimated. For the Olympic Games, the deadline for being ready is set, which puts time pressure on several investment projects. Time pressure makes construction expensive; it makes the government vulnerable to corruption and may cause pressure to change policies (e.g. regarding public procurements - as happened in Rio).

If venues are ready earlier than the Games start, the costs of maintaining them is much cheaper than the costs of a delay or the pressure to complete infrastructure in a very short time.

- R5: The IOC should maintain responsibility for the agreed structural changes and enforce its overarching power to avoid unnecessary investments.

Not to criticise the awarding process of the IOC, it is important that, after awarding the Games to a city, the IOC can insist on and monitor those investments promised during the bid. Even though recently several changes led to decreased budgets (e.g. Tokyo 2020), this study showed that changes to the master plan have often increased the costs.

The free-riding mentality of stakeholders that benefit from construction but do not have to pay for it increases the risk that, after winning a bid, some changes would lead to investment in "white elephants". It is a fact that the IOC loses influence on investment decisions after awarding the Games. The problem is that the nation/city that obtains the right to host the Olympic Games is autonomous in its decisions to invest.

The market and political powers start using the "delivering the best Games possible" argument to add projects or change the project design. Then there is governmental regulation needed to act in the public interest. The problem faced here 
is that powerful stakeholders benefit from investments (e.g. construction industry, local communities and local politicians), while the national taxpayer has to finance an overall economically inefficient project.

Local efficiency (city financial output/input) may often be very positive for an Olympic city, while national efficiency (national financial input from taxpayer/ national financial benefit for taxpayers) is debatable. This study showed several examples of master plan changes that raised a concern about the socially fair distribution of national resources and overall opportunity costs (see public interest theory). In this debate, exactly which infrastructure adjustments that are needed for the delivery of the Games and what is just a nice add-on should be considered. Ultimately, the IOC should have the sovereignty to select the sites specified in the candidature file as the actual sports venues for the Games. As a result, sports facilities that were not planned at the beginning should not fall under the burden of the Olympic Games.

- R6: The IOC should ensure that the host city's decision-makers extensive plans regarding the funding of each Olympic "required" investment.

Avoiding free-riding and non-efficient add-on projects which pump up the nonOCOG budgets implies that the IOC should expect a soundly estimated budget for the Games and needs to know who will fund the planned projects.

Mitt Romney, the President of SLOC, stressed this point in a letter to the government saying: "In order to form the foundation of an effective public debate, the participants should understand which spending is actually Olympic required and Olympic related" (GAO 2000, 97). The discussion is complicated by the fact that a unified approach or agreement about the projects to be included in the final cost is often missing, and there is a tendency to also include the cost of capital investments, which would have incurred even if the Olympic Games had not been awarded to the host city (Kitchin, 2007). This also counts for some venue construction. For example, only four years before the Games in Athens, the Olympic stadium was given a nice iconic surrounding which caused high extra costs. It is debatable if this was necessary and counted as part of the needed stadium (sports place) or as an add-on recreational area. Each planner should avoid "unnecessary" additions to the project scope. 
- R7: The IOC should ensure that infrastructure costs that would have been incurred in any case are not counted in "Olympic" costs.

Overall, all non-OCOG costs need to be allocated between Olympic and non-Olympic budgets. The non-Olympic budget is not necessarily a matter of the Olympic Games. Another important aspect of cost definition concerns the split of expenditure between the government authorities and the OCOG. There is a grey area of where in practice the public authority's responsibility for venue construction stops (at construction) and the OCOG's responsibility for fitting out the venues starts.

It is suggested that "Olympic" costs be defined as expenditure on new venues and facilities for the Games and the infrastructure associated with them (PricewaterhouseCoopers 2018). "Non-Olympic" costs comprise expenditure on ancillary infrastructure such as the undergrounding of power lines. When starting to differentiate the costs, it should be recognised that the scale of the Olympic programme incurs costs to a range of central and local government bodies. They are to some extent associated with the Games, such as the costs of improving transport links, of policing the host city during the event, and of providing health services in the local area. Seemingly such activities should fall within the scope of pre-existing programmes and would be subject to usual public spending and accountability arrangements at either national or local level. However, these activities could be essential to the success of the Games and funding might be brought forward or be higher than it would otherwise have been.

- R8: Cost and revenue projections should be estimated at the Games-time value. Inflation must be accounted for on the basis of consumer price indices and construction price indices.

Changes in exchange rates and inflation rate are often unheeded, as are geographical risk, and quantity and price changes. In this study it became obvious that the handling of inflation and currency fluctuations was a major issue when discussing cost overruns. The currency used for budget projections cannot be recommended here. On the one hand, many of the revenues will be in USD, but then need to be transferred into local currency. For the construction budget projections, we recommend using local currency. The problem remains that future rates have to be estimated. 
- R9: The host government should appoint a professional executive leadership.

Coordinating the multiple (public) contributions to the Olympic Games is a key task. The government Olympic executive's leadership role is crucial. It is recommended that the executive needs the government authority and technical skills to challenge and influence all Olympic projects effectively. The executive has to be able to oversee the administratively and logistically complex Olympic programme. In contrast to this recommendation, for example, Beijing 2008 and Sochi 2014 each had only one person dealing with it. This may have led to higher costs for Sochi 2014, but also to no record for Beijing 2008.

- R10: The host government should report to the parliament annually on the estimates of non-OCOG costs.

The need for strong financial management and control on the Olympic programme is plain. It is particularly important to monitor the performance of the Olympic projects by facilitating timely decision-making on the most important projects. A regular report to the parliament, which is the representative of the taxpayers, is recommended as is providing regular public information to make the process more transparent. This means the future host governments should produce an annual report of what was spent in one year, but also an annual report of estimates of what the final costs will be. For example, the Olympic law passed by the French Parliament in February 2017 states that every year until 2024 the public auditor (Cour des Comptes) of all public expenditures in France will be in charge of elaborating on, publicising and publishing an annual report covering the actual costs and revenues accounting for the 2024 Olympic Games in the currently reported year.

- R11: Workforce and administration need to be budgeted with higher contingencies.

The Olympic Games always contain technological innovation. Examples include the construction of an iconic stadium or the OCOG depending on high-tech IT and media equipment. Technological development tends to lead to cost increases. This study revealed that these are often not adequately accounted for in initial cost estimates. This study is limited to show the cost increase for technology for the OCOGs only. However, the technology needed for Olympic venues showed no severe cost overruns even though the organisers always had concerns. For the Olympic 
Games, it was proven that workforce and administration and coordination seem to be those categories with highest cost overruns and therefore here contingencies should be planned higher at the bidding stage.

- R12: Legacy transformation costs need to be planned and budgeted from the very beginning.

The post-Olympic use (legacy) of each (sporting and non-sporting) venue should be defined from the moment the bid file is being put together and finalised in the initial phase of Olympic preparation, in line with the (revised, if necessary) master plan of the host city. This suggestion is useful to stick to the planned projects and their long-term use. This could at least hinder excessive extensions of the sub-projects. However, the study showed many cases where flexibility was needed and adjustments of the master plan were good.

- R13: Host cities/the IOC should insist on maximising legacy through capacity reduction and post-event planning.

Further, the seating capacities of the Olympic venues should be adjusted to their anticipated use in the post-Olympic period. They may be only temporarily enlarged for the Olympic Games. Additionally, in cooperation with the International Federations, the IOC could take the lead in trying to schedule a number of international (sporting and non-sporting) events as early as possible in the post-Olympic period. This would help to sustain the momentum and facilitate the integration of the Olympic venues into city life (Cartalis 2015). However, if no event can be dedicated, this may be an early sign that the venue will not have a great legacy. The post-Games use would add revenues without having new high costs. Then the revenue generation would also be post-Games.

- R14: The IOC should undertake measures together with the host government with a view to increasing transparency in relation to budget, cost and revenue changes.

This study has shown that the financing of the Olympic Games means coordinating a high number of projects (not all of them infrastructure) and also means coordinating many shareholders with different interests and agendas. Information 
asymmetry is huge, and even investigative journalism is almost unable to illustrate a full picture of the Games. When public money is involved, the taxpayers have expectations regarding a post-Games benefit. However, we observed that some stakeholder interests led to opportunistic behaviour. It may be a way to start including cost-specific (e.g. escalation) clauses as a part of contract agreements. Those who are in power or the free riders that benefit from the Olympic Games but do not pay for it often are interested in increasing information asymmetry (which means increasing the lack of transparency).

- R15: The delivery authority has to maintain a clear focus on the need for timely decision-making individually and collectively on an Olympic programme, in particularl when there are multiple stakeholders and interests.

In order not to lose control over the project interests and to always reflect whose money is spent and who are the beneficiaries of the Olympic Games, a delivery authority has to keep a clear focus. Legacy plans need to be produced. Decision-making is important at all stages in the project life cycle cost. The authority should act in the public interest.

- R16: The IOC should create a consistent financial category system.

When sifting and putting together the budgets of the different host cities, many discrepancies in the presentation were noticed. Especially in previous years of the Games, no uniform categorisation was used by the organising committees. In Sochi, at least the comparability within a Games edition was possible because a uniform categorisation was used. Nevertheless, this comparability between the Games has been difficult until now. A more detailed categorical system should be developed that clearly identifies which components belong to a category. After that, this category system must also be applied to the candidature file to be more comparable over the whole preparation process.

- R17: A first serious budget estimate should be made only once there is a valid overview of the overall project.

As our results show, budget estimates change when the organising committee is founded. The initial estimate of the organising committee is usually found four 
years before the Games were staged. Everyone involved can assume that the budget set up in the candidature file does not cover the actual costs, so why it is still required? This recommendation might be problematical for the population, since their approval can only be given if they are informed about the costs.

- R18: The IOC should ensure that the Organising Committee conducts, in collaboration with relevant partners, a cost-benefit analysis before and after the Olympic Games.

Cost and revenues are only the tangible economic dimension of sustainable development. The social, environmental and intangible economic implications are ignored in economic impact studies. Cost-benefit analysis (CBA) investigate the expected balance of benefits and costs, including an account of the status quo (to not stage the Olympics). A CBA helps predict whether the benefits of the target to be achieved by the Olympic Games (e.g. by the legacy plan) outweigh its costs, and by how much, relative to other alternatives or the not hosting of the Games. It is difficult to conduct accurate CBA. Thus a standard should be defined by IOC before the host cities undertake an analysis. At the end a CBA offers an informed estimate (if conducted prior to the Games) or a more complete cost-benefit ratio (after the Games) including intangible effects. However, a perfection in terms of economic efficiency and social welfare is not guaranteed but the IOC, the host population and politicians are much better informed about the outcome of the Games.

\subsection{Summary and Outlook}

With Olympic Agenda 2020, the IOC has developed the process and the form of the Olympic Games. The IOC implemented 40 recommendations which should be in action until 2020 (IOC n. d.). Some of these recommendations refer to our practical recommendations to reduce cost overruns.

The first recommendation of Olympic Agenda 2020 relates to the shaping of the bidding process as an invitation and includes the selection of the best project which matches most in terms of sports, economic, social and environmental long-term requirements in the planning. Furthermore, the IOC will provide an assistance phase for cities that want to apply for the Olympic Games to get a better understanding of hosting the Olympic Games. This recommendation includes the will to maximise the use of existing venues and temporary facilities. There is also the possibility to 
host competitions outside the city or country. This first and very important recommendation refers to some of our recommendations to reduce cost overruns. In our first recommendation, we advise giving earlier orientation about the required capital investments. Similarly, the host cities should avoid unnecessary investments (recommendation 5) and maximise the utilisation of legacy (recommendation 13).

The second recommendation of Olympic Agenda 2020 concerns the budget in general, and in particular the two budgets for long-term investment in infrastructure and return on such investment on the one hand, and the operational budget on the other hand. The IOC wants to clarify the elements (accounting systems). This directly relates to our recommendations 8,11 and 16 , which refer to the estimate of the budget. It is necessary to calculate the costs and revenues of the Games in Games-time value by taking inflation into account (recommendation 8). Even though our recommendation has already been included in the IOC bidding process since 2016, the host cities often communicate the cost and revenue only in the value of the bidding time. Further, the workforce and administration categories should be budgeted with higher contingencies or planned more realistically, because they proved to have high cost overruns (our recommendation 11). A last recommendation regarding budget is number 16 . We suggest that the IOC should develop a consistent, standardised category accounting system, which should be used from the first budget estimate to the final budget. This increases transparency for the IOC, planners, politicians and citizens regarding cost and revenue developments.

Strengthening of the IOC advocacy capacity is addressed in recommendation 21 of Olympic Agenda 2020. This reflects the avoidance of unnecessary investments in our 5 th recommendation. The IOC should have the sovereignty to select the sites specified in the candidature file as the actual sports venues for the Games. Then a city cannot easily change locations and venues based on national stakeholder interests.

The 27th recommendation of Olympic Agenda 2020 is related to compliance with the basic principles of good governance. Therefore we suggest that the OCOG and delivery authority should have to provide an annual financial report to the government (our recommendation 10). Further, the IOC and the host government should implement measures to increase transparency around the budget, costs and revenue changes (our recommendation 14). Our two suggestions can also be found in recommendation 29 of Olympic Agenda 2020. Here the IOC demands increased transparency by providing financial statements, annual activities, etc.

Olympic Agenda 2020 is a good step forward to reform the Olympic Movement. Hence the IOC could consider our recommendations, because they can help to significantly reduce cost overruns or at least reduce the risk of cost overruns. Many of our recommendations increase transparency. This is an important step to increase the desire of politicians, industry and population to host future Olympic Games. 
Open Access This chapter is licensed under the terms of the Creative Commons Attribution 4.0 International License (http://creativecommons.org/licenses/by/4.0/), which permits use, sharing, adaptation, distribution and reproduction in any medium or format, as long as you give appropriate credit to the original author(s) and the source, provide a link to the Creative Commons licence and indicate if changes were made.

The images or other third party material in this chapter are included in the chapter's Creative Commons licence, unless indicated otherwise in a credit line to the material. If material is not included in the chapter's Creative Commons licence and your intended use is not permitted by statutory regulation or exceeds the permitted use, you will need to obtain permission directly from the copyright holder.

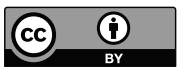




\section{References}

Abd-Karim, A., Memon, A. \& Abdul-Rahman, I. (2013). Relationship between Factors of Construction Resources Affecting Project Cost. Modern Applied Science, 7 (1), 67-75.

Abdel-Hafeez, M. M., El-Attar, S. S. \& Abdel-Hafeez, W. A. (2016). Factors Leading to Cost Overrun Occurrence in Construction Projects. Port Said Engineering Research Journal, 20 (1).

Abdulkadir, S., Muhammad, A. I., Gidado, U. M. \& Nuruddeen, U. (2017). Cost and Time Overrun in Building Projects: Professional Attitude and Incidence Rate in Practice. International Journal of Economics, Commerce and Management, 5 (8), 276-283.

Abusafiya, H. A. M. \& Suliman, S. M. A. (2017). Causes and Effects of Cost Overrun on Construction Project in Bahrain: Part 2 (PLS-SEM Path Modelling). Modern Applied Science, 11 (7), 28-37.

ACOG (1994). 1991-1997 financial forecast update, unpublished data, Atlanta.

Aftab, H. M., Ismail, A. R., Noor, Y. Z. \& Ahmad, T. A. K. (2014). Web-based Risk Assessment Technique for Time and Cost Overrun (WRATTCO) - A Framework. Procedia - Social and Behavioural Sciences, 129, 178-185.

Aibinu, A. A. \& Jagboro, G. O. (2002). The effects of construction delays on project Delivery in Nigerian construction industry. International Journal of Project Management, 20, 593-599.

Alfouzan, A. S. (2013). Analyzing the factors that lead to housing and construction cost escalation: A case study focused on Riyadh, Saudi Arabia. M.Sc. Thesis. Kentucky: Western Kentucky University.

Ali, M., Ali Mangi, S. Sohu, S., Jamali, Q. B. \& Kateemullah (2017). Major Factors of Budget Overrun in Construction of Road Project of Sindh, Pakistan. Engineering Science and Technology International Research Journal, 1 (2), 28-32.

Alinaitwe, H., Apolot, R. \& Tindiwensi, D. (2013). Investigation into the Causes of Delay and Cost Overrun in Uganda's Public Sector Construction Projects. Journal of Construction in Developing Countries, 18 (2), 33-47.

(C) The Author(s) 2019

$\mathrm{H}$. Preuß et al., Cost and Revenue Overruns of the Olympic

Games 2000-2018, Event- und Impaktforschung,

https://doi.org/10.1007/978-3-658-24996-0 
Alm, J. (2012). World Stadium Index. Stadiums built for major sporting events - bright future or future burden? Idraettens Analyseinstitut \& Play the Game. Retrieved 13 May 2018 www.playthegame.org/media/1965212/world_stadium_index_final.pdf

Al-Jurf, N.A. \& Beheiry, S. (2010). Qatar residential construction projects. Second engineering systems management and its applications international conference (ICESMA), 1-6.

Ameh, O., Soyingbe, A. \& Odusami, K. (2010). Significant Factors Causing Cost Overruns in Telecommunication Projects in Nigeria. Journal of Construction in Developing Countries, 15 (2), 49-67.

Andreff, W. (2007). French Football: A Financial Crisis Rooted in Weak Governance. Journal of Sports Economics, 8 (6), 652-61.

Andreff, W. (2012). The winner's curse: why is the cost of sports mega-events so often underestimated? In W. Maennig \& A. Zimbalist (eds.), International Handbook on the Economics of Mega Sporting Events (37-69). Cheltenham: Edward Elgar.

Andreff W. (2013). Pourquoi les Jeux de Sotchi seront plus coûteux que prévu. La Revue Internationale et Stratégique, 92, 109-118.

Andreff W. (2014). The Winner's Curse in Sports Economics. In O. Budzinski \& A. Feddersen (eds.), Contemporary Research in Sports Economics (177-205). Frankfurt am Main: Peter Lang Academic Research.

Andreff W. (2015). Governance of professional team sports clubs: agency problem and soft budget constaint. In W. Andreff (ed.), Disequilibrium Sports Economics: Competitive Imbalance and Budget Constraints (175-227). Cheltenham: Edward Elgar.

Andreff, W. (2016). The cost of hosting international sports events. In U. Wagner, R. K. Storm \& K. Nielsen (eds.), When sport meets business. Capabilities, challenges, critiques (219-233). Los Angeles: Sage Publications.

Anti Corruption Foundation (n. d.). Sochi 2014: Encyclopaedia of spending, Moscow.

Arrow, K. (1985a). The economics of agency. In J. Pratt \& R. Zeckhauser (eds.), Principals and agents: The structure of business (37-51), Boston: Harvard Business School Press.

Arrow, K. (1985b). The Potentials and Limits of the Market in Resource Allocation, in G.R. Feiwel (ed.), Issues in Contemporary Microeconomics and Welfare (pp. 107-124), London: The Macmillan Press.

Athens 2004 Olympic Bid Committee (1996). Athens 2004 Candidate City, Athens.

ATHOC (n. d.). Athens Venue Costs Extract from Hellenic Olympic Properties. Excel manuscript. ATHOC (2003). Athens 2004. Liability Underwriting Information, Athens.

ATHOC (2004). Finance workshop - ATHOC debrief to BEIJING 2008. PowerPoint manuscript. ATHOC (2005a). Final Report balance. Excel manuscript.

ATHOC (2005b). Official report of the XXVIII Olympiad: Athens 2004, Athens.

Aumüller, J. (2014, February 7). Danke, Steuerzahler. Süddeutsche Zeitung, 31, 28.

Australian Bureau of Statistics (2018). Australian National Accounts: National Income, Expenditure and Product. Retrieved 16 April 2018 from http://www.abs.gov.au/ausstats/ abs@.nsf/mf/5206.0

Bageis, A. \& Furtune, C. (2009). Factors Affecting the Bid/ No bid decision in the Saudi Arabian Construction Contractors. Construct Management and Economics, 27 (1), 53-71.

Baldry, D. (1998). The evaluation of risk management in public sector capital projects. International Journal of Project Management, 16 (1), 35-41.

Baloyi, L. \& Bekker, M. C. (2011). Project Construction Delays and Cost Overruns: A Comparative Review of the Construction of 2010 FIFA World Cup Stadia in South Africa. Proceedings ISEM 2011 Stellenbosch, 23/1-23/12. 
Banaitiene, N. \& Banaitis, A. (2012). Risk management in Construction Projects. In N. Banaitiene (ed.), Risk Management - Current Issues and Challenges (429-448). Rijeka: InTech.

Beijing 2008 Olympic Games Bid Committee (2001). Beijing 2008: Candidate City, Beijing.

Berechman, J. \& Chen, L. (2011). Incorporating Risk of Cost Overruns into Transportation Capital Projects Decision-Making. Journal of Transport Economics and Policy, 45 (1), 83-104.

BOCOG (n. d.). BOCOG Expenditures and Revenue Final Reports. Excel manuscript.

BOCOG (2007). BOCOG Budget Table April 2007. Excel manuscript.

Bondonio, P. \& Campaniello, N. (2006). Torino 2006: What Kind of Olympic Winter Games Were They? Olympika XV, 1-33.

Bondonio, P. \& Guala, A. (n. d.). Torino 2006 Winter Olympic Games - An "Intangible to Tangible" Legacy Case Study. OMERO, unpublished manuscript.

Bordat, C., McCullouch, B. G., Labi, S. \& Sinha, K. (2004). An analysis of cost overruns and time delays of INDOT projects. West Lafayette: Joint Transportation Research Program.

Botella, J. (1995). The political Games Agents and Strategies in the 1992 Barcelona Olympic Games. In M. Moragas Spà \& M. Botella (eds.), The Keys to Success (139-148). Barcelona: Universitat Autonoma de Barcelona.

Botella, M. (1995). Organization of the Games. In M. Moragas Spà \& M. Botella (eds.), The Keys to Success (18-42). Barcelona: Universitat Autonoma de Barcelona.

Bottero, M., Sacerdotti, S. L. \& Mauro, S. (2012). Turin 2006 Olympic Winter Games: impacts and legacies from a tourism perspective. Journal of Tourism and Cultural Change, 10 (2), 202-217.

British Columbia Olympic and Paralympic Winter Games Secretariat (2004). Progress Report November 30, 2004, Vancouver.

British Columbia Olympic and Paralympic Winter Games Secretariat (2010). British Columbia's Investments in the 2010 Olympic and Paralympic Winter Games and Related Activities, Vancouver.

Bruzelius, N., Flyvbjerg, B. \& Rothengatter, W. (1998). Big decision, big risks: improving accountability in megaprojects. International Review of Administrative Science, 64 (3), $423-440$.

Bull, A. (2016, July 27). Revealed: the biggest threat to the future of the Olympic Games. Retrieved 11 April 2018 from https://www.theguardian.com/sport/2016/jul/27/biggestthreat-future-olympic-games-rio-2016-ioc-thomas-bach-hosts

BusinessDictionary (n. d. a). Cost Overrun. Retrieved 11 April 2018 from http://www.businessdictionary.com/definition/cost-overrun.html

BusinessDictionary (n. d. b). Change orders. Retrieved 26 July 2018 from http://www.businessdictionary.com/definition/change-order.html

Camara dos Deputados (2017). Informacoes sobre Despesas com os Jogos Olimpicos e Paralimpicos Rio 2016. Retrieved 12 January 2018 from http://www2.camara.leg.br/orcamento-da-uniao/estudos/2017

Cambridge Dictionary (n. d.). Evolution. Retrieved 16 July 2018 from https://dictionary. cambridge.org/ dictionary/english/evolution

Cantarelli, C.C., Flyvbjerg, B. \& Buhl, S. L. (2012). Geographical variation in project cost performance: The Netherlands versus worldwide. Journal of Transport Geography, 24, 324-331.

Capen, E., Clapp, R. \& Campbell, W. (1971). Competitive bidding in high- risk situations. Journal of Petroleum Technology, 23, 641-53. 
Cartalis, C. (2015). Mega-events as catalysts for sustainable urban development: The Case of Athens 2004. In V. Viehoff \& G. Poynter (eds.), Mega-event Cities: Urban Legacies of Global Sports Events (185-198). London, New York: Routledge.

CBC (2015, June 8). Winter Olympics add 4 new events for 2018. Retrieved 2 May 2018 from http://www.cbc.ca/sports/winter-olympics-add-4-new-events-for-2018-1.3104532

Coakley, J. \& Souza, D. L. (2013). Sport mega-events: Can legacies and development be equitable and sustainable? Motriz, Rio Claro, 19 (3).

COJOPR (2015). Rio 2016 Jul 15. Excel manuscript.

COJOPR (2016a). Rio Budget evolution estimates. Excel manuscript.

COJOPR (2016b). Rio 2016 Jun 2016. Excel manuscript.

Creedy, G. D. (2004). Risk factors leading to cost overrun in highway construction projects. Driving Innovation International Conference 25 to 27 October 2004 on the Cold Coast, Queensland.

Creedy, G. D., Skitmore, M. \& Wong, J. K. W. (2010). Evaluation risk factors leading to cost overrun in delivery of highway construction projects. Journal of Construction Engineering and Management, 136 (5), 528-536.

data 360 (2008). Turner Building Cost Index. Retrieved 17 April 2018 from http://www. data360.org/ dsg.aspx?data_Set_Group_Id=850

Department for Business Innovation and Skills (2012). Construction Tender Price Indices. Retrieved 17 April 2018 from https://www.gov.uk/government/statistics/bis-pricesand-cost-indices

DCMS (Department for Culture, Media and Sport) (2012a). London 2012 Olympic and Paralympic Games Quarterly Report June 2012, London.

DCMS (Department for Culture, Media and Sport) (2012b). London 2012 Olympic and Paralympic Games Quarterly Report December 2012, London.

Detail (2012, July 28). London 2012 - Basketball Arena. Retrieved 04 June 2018 from https:// www.detail-online.com/article/london-2012-basketball-arena-16397/

Doloi, H. (2013). Cost overruns and Failure in Project Management: Understanding the Roles of Key Stakeholders in Construction Projects. Journal of Construction Engineering \& Management, 139 (3), 267-279.

Eurostat (2018). Construction cost (or producer prices), new residential buildings. Retrieved 16 April 2018 from http://ec.europa.eu/eurostat/web/products-datasets/-/sts_copi_a

Fama, E.F. \& Jensen, M.C. (1983). Agency Problems and Residual Claims. Journal of Law \& Economics, 23 (3), 327-49.

FAZ (2004, September 7). Peking will Kosten für Olympia drastisch senken. Frankfurter Allgemeine Zeitung, 32.

Fay, T. (2018). Research, personal archive and interview, 12.5.2018.

Flyvbjerg, B. (2009). Survival of the unfittest: Why the worst infrastructure gets built - and what we can do about It. Oxford Review of Economic Policy, 25 (3), 344-367.

Flyvbjerg, B. (2011). Over Budget, Over Time, Over and Over Again. Managing Major Projects. In P. W. G. Morris, J. K. Pinto \& J. Söderlund (eds.), The Oxford Handbook of Project Management (321-344). Oxford: Oxford University Press.

Flyvbjerg, B., Bruzelius, N. \& Rothengatter, W. (2003). Megaprojects and Risk: An Anatomy of Ambition. Cambridge: Cambridge University Press.

Flyvbjerg, B., Garbuio, M. \& Lovallo, D. (2009). Delusion and deception in large infrastructure projects: two models for explaining and preventing executive disaster. California Management Review, 51 (2), 170-193. 
Flyvbjerg, B., Holm, M. S. \& Buhl, S. L. (2002). Underestimating Costs in Public Works Projects. Error or Lie? Journal of the American Planning Association, 68 (3), 279-295.

Flyvbjerg, B., Holm, M. S. \& Buhl, S. L. (2005). How (in)accurate are demand forecasts in public works projects? The case of transportation. Journal of the American Planning Association, 71 (2), 131-146.

Flyvbjerg, B., Stewart, A. \& Budzier, A. (2016). The Oxford Olympics Study 2016: Cost and Cost Overrun at the Games (RP 2016-20). Said Business School.

Gajewska, W. \& Ropel, M. (2011). Risk Management Practices in a Construction Project - a case study. M.Sc. Thesis. Göteborg: Chalmers University of Technology, Department of Civil and Environmental Engineering.

GAO (United States General Accounting Office) (2000). Report to Congressional Requesters. Olympic Games. Federal Government Provides Significant Funding and Support, Washington D.C.

GAO (United States General Accounting Office) (2001). Report to the Ranking Minority Member Subcommittee on the Legislative Branch Committee on Appreciations U.S. Senate. Olympic Games. Costs to Plan and Stage the Games in the United States, Washington D.C.

General Manager of Financial Services and General Manager of Olympic Operations (2010). 2010 Olympic and Paralympic Winter Games - Cost Estimates, Vancouver.

Gibson, O. (22.02.2011). Olympic velodrome opens on time, on budget and is 'best in the world'. Retrieved 04 June 2018 from https://www.theguardian.com/sport/2011/feb/22/ olympic-2012-games-velodrome-open

Girginov, V. \& Parry, J. (2005). The Olympic Games explained. Abingdon: Routledge.

Golden, F. (2013, August 22). Norwegian cruise ship to serve as hotel for Olympics. Retrieved 2 May 2018 from https://eu.usatoday.com/story/cruiselog/2013/08/22/norwegian-jade-sochi-russia-winter-olympics/2684291/

Gomez Arcila, S. (2012). Avoiding cost overrun in construction projects in UK. M.Sc. Thesis. The University of Warwick.

Halloum, M. A., \& Bajracharya, A. A. (2012). Cost and time overrun revisited: A study on the infrastructure construction projects in Abu Dhabi. Bangkok: The Third Conference on Construction in Developing Countries.

Hantke-Domas, M. (2003). The Public Interest Theory of Regulation: Non-Existence or Misinterpretation? European Journal of Law and Economics. 15 (2), 165-194.

Helbing, B. (2015). Olympic Realities: Six Cities after the Games. Basel: Birkäuser.

Homewood, B. (2017, June 9). Olympics committee approves major changes for 2020 games. Retrieved 2 May 2018 from https://www.aol.com/article/news/2017/06/09/olympics-committee-approves-major-changes-for-2020-games/22134841/?guccounter $=1$

Hong, S.-P. (2017). Request Capital Investment Olympic Winter Games PyeongChang 2018 [E-Mail; 26.12.2017].

Hopkins, B. (2002). Games Budget Risk Management. Debriefing of the XIX Olympic Winter Games Salt Lake City 2002.

House of Commons (2010). Financing the London 2012 Olympic Games, London.

Insja, D. \& Sihombing, L. B. (2016). Identification of factors affecting cost overrun in the construction of Industrial Buildings. Malaysian Journal of Industrial Technology, 2 (1), 1-6.

IOC (International Olympic Committee) (n. d.). Olympic Agenda 2020. 20+20 Recommendations. Retrieved 03 August 2018 from https://stillmed.olympic.org/media/ Document\%20Library/OlympicOrg/Documents/Olympic-Agenda-2020/Olympic-Agenda-2020-20-20-Recommendations.pdf\#_ga=2.195825644.152302433.1532944306-514594009.1513156051 
IOC (International Olympic Committee) (2010). 2018 Candidature Procedure and Questionnaire. Lausanne: IOC.

IOC (International Olympic Committee) (2014). 2014 Annual Report of the IOC. Lausanne: IOC. IOC (International Olympic Committee) (2018). OC and OWG key figures. Excel manuscript. IOC (International Olympic Committee) (2018b). Olympic Games the New Norm Report. Retrieved 29 September 2018 from https://stillmed.olympic.org/media/Document\%20 Library/OlympicOrg/News/2018/02/2018-02-06-Olympic-Games-the-New-Norm-Report. pdf\#_ga=2.91939987.822564896.1534495451-1382914788.1518533455

Inuwa, I. I., Saiva, D. \& Alkizim, A. (2014). Investigation Nigerian Indigenous Contractors Project Planning In Construction Procurement: An Explanatory Approach. International Journal of Civil \& Environmental Engineering, 14 (4), 16-25.

IOBE (Foundation for Economic \& Industrial Research) (2015). The impact of the 2004 Olympic Games on the Greek economy, Athens.

Jackson, S. (2002). Project Cost Overruns and Risk Management. 18th Annual ARCOM Conference, 2-4 September 2002, University of Northumbria. Association of Researchers in Construction Management, Vol. 1, 99-108.

Jensen, M. \& Meckling, W. (1976). Theory of the Firm: Managerial Behavior, Agency Costs, and Ownership Structure. Journal of Financial Economics, 3 (1), 305-360.

Kahneman, D., \& Tversky, A. (1979). Intuitive prediction: biases and corrective procedures. TIMS Studies in Management Science, 12, 313-327.

Kao, J. S. (2016, 6 August). The cost of building the 2016 Rio Olympics. Financial Times. Retrieved 04 May 2018 from https://www.ft.com/content/52ce2456-5b71-11e6-9f70-badea1b336d4

Kasimati, E. (2015). Post Olympic Use of the Olympic Venues: The Case of Greece. Athens Journal of Sports, 2 (3), 167-184.

Kasimov, N. S. (2015). OGI Report No.3 Impact Review. Moscow: Lomonosov Moscow State University.

Kasimu, A. M. \& Abubakar, D. I. (2012). Causes of Delay in Nigeria Construction Industry. Interdisciplinary Journal of Contemporary Research in Business, 4 (2), 785-794.

Khodeir, L. \& Hamdy, A. (2015). Identifying the Latest Risk-Probabilities Affecting Construction Projects in Egypt according to Political and Economic Variables. HBRC Journal, 11 (1), 129-135.

Kim, E. (2011, February 25). Hopkins architects: London 2012 Olympic velodrome complete. Retrieved 04 June 2018 from https://www.designboom.com/architecture/hopkins-architects-london-2012-olympic-velodrome-complete/

Kitchin, P. (2007). Financing the Games. In J. R. Gold \& M. M. Gold (eds.), Olympic cities: City agendas, planning and the world's games, 1896-2012 (103-119). London, New York: Routledge.

Könecke, T. \& de Nooij, M. (2017). The IOC and Olympic bids from democracies and authoritarian regimes - A socioeconomic analysis and strategic insights. Current Issues in Sport Science, 2.

Kornaï, J., Maskin, E. \& Roland, G. (2003). Understanding the Soft Budget Constraint. Journal of Economic Literature, XLI (December), 1095-1136.

Kostka, G. \& Anzinger, N. (2015). Large Infrastructure Projects in Germany: A cross-sectional Analysis, Working Paper 1, Hertie School of Governance.

Koushki, P. A, Al-Rashid K. \& Kartam, N. (2005). Delays and cost increases in the construction of private residential projects in Kuwait. Journal of Construction Management and Economics, 23 (3), 285-294. 
Kwak, Y. H. \& Smith, B. (2009). Managing risks in mega defense acquisition projects: performance, policy, and opportunities. International Journal of Project Management, 27 (8), 812-820.

Kwak, Y. H., Walewski, J., Sleeper, D. \& Sadatsafavi, H. (2014). What can we learn from the Hoover Dam: that influenced modern project management. International Journal of Project Management, 32 (2), 256-264.

Laffont, J.-J. \& Martimort, D. (2003). The Theory of Incentives - The Principal-Agent Model. Journal of Economics, 80 (3), 284-287.

Lee, J. K. (2008). Cost Overrun and Cause in Korean Social Overhead Capital Projects: Roads, Rails, Airports, and Ports. Journal of Urban Planning and Development, 134 (2), 59-62.

Le-Hoai, L., Dai Lee, Y. \& Lee, J. Y. (2008). Delay and cost overruns in Vietnam large construction projects: A comparison with other selected countries. KSCE journal of civil engineering, 12 (6), 367-377.

Lenskyj, H. J. (2000). Inside the Olympic Industry: Power, Politics and Activism. Albany: State University of New York Press.

LOCOG (2008). $2^{\text {nd }} v s 1^{\text {st }}$ Games Budget. Excel manuscript.

LOCOG (2009). Tables Games Budget Evolution V1-V3. Excel manuscript.

LOCOG (2012). LOCOG Budget forecasts 2011 onwards. Word manuscript.

LOCOG (2013). Core and Grant Spend. Excel manuscript.

London 2012 Candidate City (2004). London 2012 Candidate City, London.

Love, P. E. D., Ahiaga-Dagbui, D., Welde, M. \& Odeck, J. (2017). Light rail transit cost performance: Opportunities for future-proofing. Transportation Research Part A, 100, 27-39.

Love, P. E. D., Zhou, K. J., Edwards, D. J., Irani, Z. \& Sing, C. P. (2017). Off the rails: The cost performance of infrastructure rail projects. Transportation Research Part A, 99, 14-29.

Lu, Y., Luo, L., Wang, H., Le, Y., \& Shi, Q. (2015). Measurement model of project complexity for large-scale projects from task and organization perspective. International Journal of Project Management, 33 (3), 610-622.

Lundberg, M., Jepanitsub, A. \& Pyddoke, R. (2011). Cost overrun in Swedish transport projects. CTS Working Paper. Stockholm: Centre for Transport Studies, KTH.

Lundy, M. (2013, 24 June). Brazilians have reason to protest the cost of Olympics and World Cup. The Globe and Mail. Retrieved 04 May 2018 from https://www.theglobeandmail. com/opinion/ brazilians-have-reason-to-protest-the-cost-of-olympics-and-world-cup/ article12742114/

Magnay, J. (2012, July 19). London 2012 Olympics: wet weather causes last-minute construction issues on the Olympic Park. Retrieved 2 May 2018 from https://www.telegraph.co.uk/ sport/olympics/9412048/London-2012-Olympics-wet-weather-causes-last-minute-construction-issues-on-the-Olympic-Park.html

Mahamid, I. \& Bruland, A. (2011). Cost overruns Causes in Road Construction Projects: Consultants' Perspective. $2^{\text {nd }}$ International Conference on Construction and Project Management, IPEDR vol. 15. Singapore: IACSIT Press.

Massiani, J. (2018). Introduction. Venice workshop on the economic impact of mega events. Venice 30.4.2018.

McKinsey, G. I. (2015). Megaprojects. The good, the bad, and the better. Insights \& Publication.

Memon, A., Abdul Rahman, I. \& Abdul Azis, A. (2011). Preliminary Study on Causative Factors Leading to Construction Cost Overrun. International Journal of Sustainable Construction Engineering \& Technology, 2 (1), 57-71. 
Miceli, T.J. (2004). A Principal-Agent Model of Contracting in Major League Baseball. Journal of Sports Economics, 5 (2), 213-20.

Miller, R. \& Lessard, D. R. (2000). The Strategic Management of Large Engineering Projects: Shaping Institutions, Risks, and Governance. Cambridge, MA: MIT Press.

Millet, L. (1995). The Games of the city. In M. Moragas Spà \& M. Botella (eds.), The Keys to Success (188-202). Barcelona: Universitat Autonoma de Barcelona.

Morris, P. W. G. \& Pinto, J. K (2004). The Wiley guide to managing projects. Hoboken: John Wiley \& Sons.

Morris, S. (1990). Cost and Time Overruns in Public Sector Projects. Economic and Political Weekly, 25 (47), M154-M168.

Müller, M. (2014). After Sochi 2014: costs and impacts of Russia’s Olympic Games. Eurasian geography and Economics, 55 (6), 628-655.

National Audit Report (2009). Results of Beijing Olympic Games Financial Revenues and Expenditures Audit (Excerpts). Beijing.

National Audit Office (2007a). Preparations for the London 2012 Olympic and Paralympic Games - Risk assessment and management. HC 252. London.

National Audit Office (2007b). The budget for the London 2012 Olympic and Paralympic Games. HC 612. London.

National Audit Office (2012). The London 2012 Olympic Games and Paralympic Games: post-Games review. Report by the comptroller and Auditor general. HC 794. London.

National Statistical Service of Greece (2007). Statistical Yearbook of Greece 2005, Piraeus.

Newman, P. (2007). "Back the Bid": the 2012 Summer Olympics and the Governance of London. Journal of Urban Affairs, 29 (3), 255-267.

Nichols, J. (1999, November 5). Sydney Olympics ticketing fiasco: premium seats reserved for the rich. World Socialist Web Site. Retrieved 15 May 2018 from https://www.wsws. org/en/articles/1999/11/oly-n05.html

NSW (New South Wales Government) (n. d.). Sydney Olympic Park Authority. Retrieved 22 May 2018 from https://www.records.nsw.gov.au/agency/2152

NSW (New South Wales Government) (1998). Budget Paper, Number 2, Sydney.

NSW (New South Wales Government) (2000). Budget Statement 1999-2000. Sydney.

NSW (New South Wales Government) (2002). Budget Statement 2001-2002. Sydney.

Oberli, P. (2017, December 17). Ego et deficit, les défis que doit gérer Sion 2026. Le Matin Dimanche, 35.

OCA (1998). State of Play, June 1998, Sydney.

OCA (Olympic Coordination Authority) (1999). Update State of Play 1999, Sydney.

OCA (Olympic Coordination Authority) (2002). A Report on the Financial Contribution by the NSW Government to the Sydney 2000 Games, Sydney.

ODA (2015). Report and Accounts presented to Parliament pursuant to articles 4(3) and 5(5) of the Olympic Delivery Authority (Dissolution) Order 2014/3184. London.

Odeck, J. (2004). Cost overruns in road construction: what are their sizes and determinants? Transport Policy, 11 (1), 43-53.

Odeh, A. M. \& Battaineh, H. T. (2002). Causes of construction delay: traditional contracts. International Journal of Project Management, 20, 67-73.

Odeyinka, H., Larkin, K., Weatherup, R., Cunningham, G., McKane, M. \& Bogle, G. (2012). Modelling risk impacts on the variability between contract sum and final account (A research report submitted to Royal Institution of Chartered Surveyors). London. 
OECD (n. d.). OECD Territorial Reviews: Athens, Greece. Retrieved 8 May 2018 from http:// www.oecd.org/greece/oecdterritorialreviews-athensgreece.htm

OECD (2004). Territorial Reviews. Athens, Greece, Paris.

Osborn, C. (2017, August 4). Residents of a crisis-ridden Rio caution future Olympic hots. Retrieved 2 May 2018 from https://www.pri.org/stories/2017-08-04/residents-crisis-ridden-rio-caution-future-olympic-hosts

Panagiotopoulou, R. (2014). The Legacies of the Athens 2004 Olympic Games. Contemporary Social Science. Special Issue: The Olympic Legacy, 9 (2), 173-195.

Park, S.-K. (2016). Olympic Games Impact (OGI) Study for the 2018 PyeongChang Olympic and Paralympic Winter Games. A study from the Korea Research Institute for Local Administration Regional Economy Analysis Center. Manuscript.

Partnerships British Columbia (2007). Report on Capital Planning and Budget for 2010 Olympics Venues, Vancouver.

Patanakul, P. (2014). Managing large-scale IS/IT projects in the public sector: problems and causes leading to poor performance. Journal of High Technology Management Research, 25 (1), 21-35.

Pickrell, D. H. (1990). Urban Rail Transit Projects: Forecasts versus Actual Ridership and Cost. Publication DOT-T 91-04, US Department of Transportation.

Picot, A., Dietl, H., \& Franck, E. (2005). Organisation. Eine ökonomische Perspektive. Stuttgart: Schäffer-Pöschel.

POCOG (2014). POCOG Lifetime Budget February 2014. Excel manuscript.

POCOG (2016). POCOG Lifetime Budget November 2016. Excel manuscript.

POCOG (2018). POCOG Lifetime Budget January 2018. Excel manuscript.

Pollalis, S. N. (2006). The Roof of the Olympic Stadium for the 2004 Athens Olympic Games from Concept to Implementation. Cambridge: Harvard Design School.

Preuss, H. (2004). The Economics of Staging the Olympics. A Comparison of the Games 19722008. Cheltenham: Edward Elgar.

Preuss, H. (2006). The Olympics. In W. Andreff \& S. Szymanski (eds.), Handbook on the Economics of Sport (183-196). Cheltenham: Edward Elgar.

Preuss, H. \& Schnitzer, M. (2015). Organization costs for a FIFA World Cup and their significance during a bid. Event Management, 19, 57-72.

PricewaterhouseCoopers (2004). European Economic Outlook June 2004. Retrieved 07 May 2018 from http://www.pages.drexel.edu/ rosenl/sports\%20Folder/Economic\%20 Impact $\% 20$ of\%20Olympics\%20PWC.pdf

PricewaterhouseCoopers (2018). International Olympic Committee. The costs and benefits of the Olympic Games - final report, London.

PyeongChang 2018 Olympic \& Paralympic Winter Games Bid Committee (2010). PyeongChang 2018 Candidature File, PyeongChang.

Reuters (2014, October 1). Norway withdraws Oslo bid for 2022 Winter Games. Retrieved 11 April 2018 from https://www.reuters.com/article/us-olympics-winter-norway/norwaywithdraws-oslo-bid-for-2022-winter-games-idUSKCN0HQ4QE20141001

Richter, R. (2012a, April 19). Olympic Games and Transport Infrastructure: An Analysis. Retrieved 2 May 2018 from http://www.transportnexus.com/olympic-games-4/

Richter, R. (2012b, April 16). Olympic Games: Transport Infrastructure Development. Retrieved 2 May 2018 from http://www.transportnexus.com/olympic-games-3/

Riksrevisionsverket (1994). Infrastrukturinvesteringar: En kostnadsjämförelse mellan lan och utfall I 15 större project inom Vägverket och Banverket. Stockholm: RRV. 
Rio 2016 Candidate City (2008). Candidature File for Rio de Janeiro to host the 2016 Olympic and Paralympic Games, Rio de Janeiro.

Roche, L. R. (1994, August 9). Utah Bobsled, Luge Run to Cost \$1 Million More Than Expected. Deseret News. Retrieved 19 May 2018 from https://www.deseretnews.com/article/ 368835/ UTAH-BOBSLED-LUGE-RUN-TO-COST-1-MILLION-MORE-THAN-EXPECTED.html

Salt Lake City Bid Committee (1994). Salt Lake City Candidate to host the XIX Olympic Winter Games 2002, Salt Lake City.

Sanburn, J. (2012, 9 July). Was it worth it? Debt-Ridden Greeks Question the Cost of the 2004 Olympics. Retrieved 20 June 2018 from http://olympics.time.com/2012/07/09/amideconomic-turmoil-some-greeks-look-back-at-2004-olympics-as-losing-proposition/

Satyanarayana, J. (1974). Accumulated deficits of public enterprises. Hyderabad: Institute of Public Enterprise.

SCU (SAGE/COPPE/UFRJ Research Team) (2014). Olympic Games Impact (OGI) Study RIO 2016. Initial report to measure the impacts and the legacy of the Rio 2016 Games. Rio de Janeiro.

Senouci, A., Alsarraj, A., Gunduz, M. \& Eldin, N. (2016). Analysis of change orders in Qatari construction projects. International Journal of Construction Management, 17 (4), 280-292.

Shanmuganathan, N. \& Baskar, G. (2015). Ranking of delay factors causes time and cost overruns in construction projects in Tamil Nadu. International Journal of Applied Engineering Research, 10 (24), 54-61.

Shaqour, E. (2014). An Approach to Control Cost overrun in Construction Projects of Egypt (PhD Dissertation). Cairo: Cairo University, faculty of Engineering.

Sharot, T. (2011). The optimism bias. Current Biology, 21 (23), 941-945.

Siemiatycki, M. (2015). Cost Overruns on Infrastructure Projects: Patterns, Causes and Cures. IMFG Perspectives, 11, University of Toronto.

Singh, R. (2010). Delays and Cost Overruns in Information Projects: Extent, Causes and Remedies. Economic and Political Weekly, 45 (21), 43-54.

Singh, R. (2011). Determinants of Cost overrun in Public Procurement of Infrastructure: Roads and Railways. India Policy Forum, 7, 97-158.

SLOC (n. d.). Olympic Budget History. Excel manuscript.

SLOC (1998). Salt Lake 2002 - Basic plan for the XIX Olympic Winter Games and VIII Paralympic Winter Games, Salt Lake City.

SLOC (1999). Progress Report to the European National Olympic Committees. Salt Lake City.

SLOC (2001). New global report. Excel manuscript.

SLOC (2002a). Final cost analysis. Excel manuscript.

SLOC (2002b). Media Up-date Games Time February 2002. Salt Lake City.

Sochi 2014 Bid Committee (2006). Sochi 2014 Candidate City, Sochi.

Social Communication Secretariat (International Area Office of the President of Brazil) (2016). Security in the Rio 2016 Olympic and Paralympic Games. Brasilia. Retrieved 19 May 2018 from http://www.brasil2016.gov.br/en/presskit/files/fact-sheet-security

SOCOG (1994). Sydney Olympic Games, Sydney.

SOCOG (2001). Official Report of the XXVII Olympia: Sydney 2000 Olympic Games, Sydney. SOCOG (2002). Final budget. Excel manuscript.

Södermann, S. \& Dolles, H. (2010). Sponsoring the Beijing Olympic Games: Patterns of sponsor advertising. Asia Pacific Journal of Marketing and Logistics, 22 (1), 8-24. 
Solberg, H. A. \& H. Preuss (2007). Why mega sports events become more expensive than planned, European Association for Sport Management (EASM) conference presentation, Turin, 12-15 September.

Solberg, H. A. \& H. Preuss (2015). Major sports events. The challenge of budgeting for the venues. Event Management, 19 (3), 349-363.

SOOC (2010). Sochi 2014 Non-OCOG Budget. Excel manuscript.

SOOC (2011). Sochi 2014 Budget. Excel manuscript.

SOOC (2012). Sochi 2014 Budget. Excel manuscript.

SOOC (2013). Sochi 2014 Budget. Excel manuscript.

SOOC (2014). Sochi 2014 Final Budget. Excel manuscript.

Sovacool, B. K., Enevoldsen, P., Koch, C. \& Barthelmie, R. J. (2016). Cost performance and risk in the construction of offshore and onshore wind farms. Wind Energy, 20 (5), 891-908.

StadiumDB (n. d.). London Stadium (Olympic Stadium). Retrieved 04 June 2018 from http:// stadiumdb.com/stadiums/eng/london_olympic_stadium

State Chamber of Commerce (NSW) (2001). Sydney 2000. A Report on the Olympic Impact on Business in a Host City, Sydney.

Storm, R.K. \& Nielsen, K. (2012). Soft Budget Constraints in Professional Football. European Sport Management Quarterly, 12 (2), 183-201.

Strande, M. (2009, September 9). Dårlig tidsstyring fra dag én. TU Bygg. Retrieved 4 May 2018 from http://www.tu.no/bygg/2009/09/09/darlig-tidsstyring-fra-dag-en

Sydney Olympics 2000 Bid Limited (1993). Sydney 2000 Candidature File, Sydney.

Sydney Olympic Games Review Committee (1990). Report to the Premier of New South Wales. Sydney: Premier's Department.

Thaler, R.H. (1994). The Winner's Curse: Paradoxes and Anomalies of Economic Life, Princeton, NJ: Princeton University Press.

The Audit Office of NSW (1998). Performance Audit Report. The Sydney 2000 Olympic and Paralympic Games, Review of Estimates, NSW.

The Audit Office of NSW (1999). Performance Audit Report: The Sydney 2000 Olympic and Paralympic Games. Review of Estimates, NSW.

The Audit Office of NSW (2002). New South Wales. Auditor-General's Report 2002. Volume 2, NSW.

The Guardian (n. d.). London Olympics 2012: where does the money come from - and where's it being spent? Retrieved 12 June 2018 from https://www.theguardian.com/sport/datablog/2012/jul/26/ london-2012-olympics-money\#data

The Guardian (2003, March 26). "The preparations for Athens 2004 are turning into a theatre of the absurd”. Retrieved 2 May 2018 from https://www.theguardian.com/sport/2003/ mar/26/olympicgames

The World Bank (2018a). World Development Indicators. GDP Deflator. Retrieved 26 February 2018 from https://data.worldbank.org/indicator/NY.GDP.DEFL.ZS?year_high_desc=false

The World Bank (2018b). World Development Indicators. Official Exchange Rates. Retrieved 5 March 2018 from https://data.worldbank.org/indicator/PA.NUS.FCRF

Toh, T., Ting, C. Ali, K.-N., Aliagha, G.-U. \& Munir, O. (2012). Critical Cost Factors of Building Construction Projects in Malaysia. International Conference on Asia Pacific Business Innovation and Technology Management. Procedia - Social and Behavioral Sciences, 57, 360-367.

Torino Bid Committee (1998). Torino 2006: Candidate City, Turin.

TOROC (2005). IOC Executive Board, April 2015. PowerPoint manuscript. 
TOROC (n. d.). Summary TOROC final cost. Excel manuscript.

Trading Economics (2018). South Korea GDP-Deflator. Retrieved 26 February 2018 from https://tradingeconomics.com/south-korea/gdp-deflator

Turner (n. d.). Building Cost Index 1996 - 2006.

UEL (2013). London 2012. Olympic Games Impact Study - London 2012 Games-time Report. London.

Vancouver 2010 Candidate City (2002). The Sea to Sky Games: Vancouver 2010 Candidate City, Vancouver.

VANOC (2007). Vancouver 2010. Business Plan and Games Budget, Vancouver.

VANOC (2008). VANOC Budget - final reconciliation to Dec 2008. Excel manuscript.

VANOC (2009). VANOC Annual Report - Financial Statement. Vancouver.

VANOC (2010a). Annual Report (Dec 2010). Consolidated Financial Statements, Vancouver.

VANOC (2010b). VANOC non-OCOG budget. Excel manuscript.

VANOC (2014). Consolidated Financial Statements, Vancouver Organizing Committee for the 2010 Olympic and Paralympic Winter Games. Vancouver.

Vanston, J. H. \& Vanston, L. K. (2004). Testing the tea leaves: Evaluating the validity of forecasts. Research Technology Management, 47 (5), 33-39.

Wachs, M. (1990). Ethics and advocacy in forecasting for public policy. Business and Professional Ethics Journal, 9 (1-2), 141-157.

Williams, T. (2003). Assessing Extension of Time delays on major projects. International Journal of Project Management, 21 (1), 19-26.

Williams, T. (2004). Identifying the hard lessons from projects-easily. International Journal of Project Management, 22 (4), 273-279.

Zagorsky, J. L. (2016, February 23). How do we know the Zika virus will cost the world \$3.5 billion? Retrieved 20 June 2018 from https://theconversation.com/how-do-we-know-thezika-virus-will-cost-the-world-3-5-billion-55117

Zimbalist, A. (2015). Circus Maximus. The Economic Gamble behind Hosting the Olympics and the World Cup. Washington: Brookings Institution.

Zujo, V., CarPusic, D., \& Brkan-Vejzovic, A. (2010). Contracted Price Overrun as Contracted Construction Time Overrun Function. Technical Gazette, 17 (1), 23-29. 